\title{
第42回日本内分泌学会総会講演抄録 ( I )
}

\author{
昭和44年 5 月 $15 ， 16 ， 17$ 日 於 群馬会館，会長 群馬大学医学部 七条小次郎 教授
}

○印 演者

\section{TSH 分泌の中枢性調節（第35報）}

Throtropin Release における交感神経機序

$$
\begin{aligned}
\text { 神大辻内科 辻 昇三, 佐古田雅弘, 鶁尾 四郎, 田中一郎, 中林 弘好 } \\
\text { 福田 恒夫, 玉岡 昌則, 深津 泰良, 大久保理夫 }
\end{aligned}
$$

目的：従来からTRFによる Thyrotropin Release を検討して来たが，今回は Thyrotropin Release に際する交感神経機序の関与について交感神経遮断効果をもつ薬剤を用いPharmacoendocrinological な検 討を行なつた. 方法：Mckenzie に準じて検討した雄 S.W. 系ラット血漿 TSH 活性の変動を示標とした. 即ち甲状腺剔除，高温馴化ラットの寒冷曝露に際してみられる血漿 TSH 活性の増量に対する交感神経遮断 薬剤の修飾効果を観察した。交感神経遮断効果を有する薬剤としては Reserpine，Phenoxybenzamine， Propranolol, Guanethidine, Bretylium を用いた。結果 : Reserpine は寒冷曝露, Guanethidine は甲状腺 剔除, Phenoxybenzamine は両者の条件におけるラット血漿 TSH 活性の増量を種々の程度に抑制した。 使用した範囲の投与量で propranolol は両条件における TSH 増量を抑制せず， Bretylium は甲状腺剔除 後の TSH 増量を抑制しなかつた。なお，Phenoxybenzamine は甲剔後増量した血漿 TSH を Thyroxine

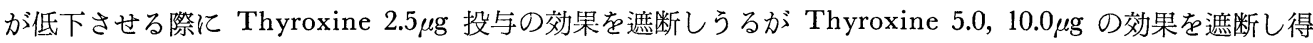
なかつた。断案：Thyrotropin Release に際して交感神経機序の関与が推定される.

質 問：京大第一内科 永田 格 TSH $0.5 \mathrm{mU}$ にインデラル $2 \mathrm{mg}$ を同時に加えるか，TSH 投与前 12時間， 2 時間にインデラルを加えておくと TSH 活性が bioassay 上発現しなかつた，先生にはてのよ うな経験はなかつたか.

応 答：神大辻内科 佐古田雅弘 TSH と propranolol を同時に投与して TSH 効果を観察した経験 はないが，本質的な問題であり今後充分検討したいと考えている.

2. $\mathrm{T}_{4}$ の異所性移植脳下垂体の機能抑制効果

群大第一内科 柁原 昭夫, 七条小次郎

我々は先に異所性に移植した下垂体が視床下部の支配を受け, 徵量の $\mathrm{T}_{4}$ が視床下部においても作用し, 異所性下垂体の TSH 分泌抑制により甲状腺機能の抑制される事を報告した。 $\mathrm{T}_{4}$ は下垂体において TSH の分泌を抑制する事は既に知られているが，本汴験では異所性に移植した下垂体に直接 $\mathrm{T}_{4}$-寒天ペレットを 移植し， ${ }^{131} \mathrm{I}$ 摂取率及びペーパークロマトにより甲状腺機能を測定し興味ある結果が得られたので報告する。

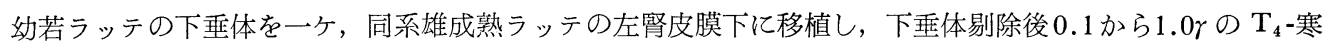
天ペレットを移植した下垂体内に移植, 対照群は右婜皮膜下に $\mathrm{T}_{4}$-寒天ペレットを移植した。 $0.1 \gamma の \mathrm{~T}_{4}$ 寒天ペレットを移植した群では, 対照群に比較し, ${ }^{131} \mathrm{I}$ 甲状腺 4 時間摂取率及び甲状腺ホルモン産生に有意 の差の認められた事から，TSH 分泌の抑制が起つたものと推定された。

質問：神大辻内科 佐古田雅弘：逝離下垂体では TSH 抑制に必要とする $\mathrm{T}_{4}$ の量が大変微量である が, intact rat（遊離下垂体でないラット）では TSH 抑制に要する $\mathrm{T}_{4}$ 量はどれ位か.

質 問：群大内分泌研 松崎 茂 $\mathrm{T}_{4}$ の TSH 分泌に対する抑制効果は, この実験の場合, TRF で促 進される分泌に対してであるか，あるいは basal な分泌汶して働くのか.

質 問 : 東北大病理 佐々木 下垂体剔除術の確実性について

応 答：群大第一内科 柁原 昭夫 2 . 下垂体剔除術の生存率は $80 \sim 90 \mathrm{~T} \%, 3 . \mathrm{T}_{4}$ は $\mathrm{TRF}$ の分泌 第 45 巻 第 4 号 
抑制的に作用する。 4. Intact では視床下部の $\mathrm{T}_{4}$ を注射した場合1.0rで甲状腺の release に変化が認めら れ，2.0〜2.5r以上で Periphery に注射した場合甲状腺抑制効果が認められた。

3. 甲状腺ミクロゾーム免疫家鬼血清中の甲状腺刺戟物質

京大第一内科 永田 格, 勝浦 淑江, 脇坂 行一

人 (又は同種家鬼) 甲状腺ミクロゾーム（又は全ホモジネート）により免疫した家鬼血清中には各種甲状 腺抗体と共に，甲状腺刺激物質が出現し， bioassay 上 LATS と TSH との中間反応を示す場合が屡々観 察された。それは飽和硫安40\%添加にて沈澱し，DEAE-Sephadex A-50 又は, Sephadex G-200 にて分画 すると， $\gamma$-G1 に随伴する部分と，TSH 抽出法（エタノール食塩）により抽出される部分とに分かれた. 免疫電気泳動上前者には $\gamma$-G1 その他の血清成分の混在が認められたが，後者には $\gamma$-G1 の存在は証明され なかつた。 モルモット抗家鬼 $\gamma$-G1 血清により前者のみが中和され, 家鬼抗牛 TSH 血清（ウサギ下垂体 $\mathrm{TSH}$ を十分中和する）では何れも中和されなかつた（要再検）， $\mathrm{T}_{4} 400 \sim 300 \mu \mathrm{g}$ 隔日投与により，前者の 受ける影響は不明瞭であつたが，後者の活性減少は明らかに認められた。 人血清 $\gamma$-G1 又は牛 TSH にて同 様に免疫された家瓜甲状腺の重量，とくに細胞高増加は，甲状腺免疫群よりはるかに顕著で，血中 TSH （エタノール食塩抽出）の増加も証明され，その細胞高増加は内因性 TSH 刺激に起因すると考えられた。 以上により，甲状腺免疫家鬼血中における甲状腺刺激物質には，免疫操作によって非特異的に増加する内因 性 TSH と，甲状腺成分による免疫の結果特異的に生成される， $\gamma-\mathrm{G} 1$ と不可分な物質（抗体）とがある，そ してそれはバセドウ病におけるLATS と analogous である，と考えられる.

質 問：阪大第一内科 網野 信行 microsomal fraction が実験的に作成した Bates Fraction に含ま れる TSH 様活性を中和するとのととであるが，私達は LATS 活性を中和する人甲状腺 cell sap では H-TSH 活性を全く中和しないとの成績を得ている. 先生のいわれる Bates Fraction の活性が TSH だと すると, microsome で中和されるととは，どの様に考えているか.

質 問：虎の門病院内分泌科 紫管 良昌 1) バセドウ病以外の甲状腺のホモジネートを用いて immunizat-ion をされたととがあるかどうか，その結果は，バセドウ病用状腺を用いた場合と差があるか.

2 ) 家鬼血清中の LATS 様活性の 2 時間值 8 時間值はいかに, anti-TSH antibody で吸収したものは本 当に 8 時間值が 2 時間值よりも高いか.

応答：京大第一内科 永田 格 (1) Anti-B・TSH 亿対し, 今回の Bates fraction は neutralizeさ れず，説明困難で，再検予定だつたが，出来なかつた。 anti-B・TSH に問題があるが, Microsome 亿 TSH が吸着され難いとのととであるが，私共では吸着された，そのメカニズムについてはいろいろあるだろうが， 事実のみ申し上げる。 (2) Anti-B・TSH を作用させたとき stimulator の bioassay 互の response の time course について, 後述のように用いた anti-B·TSH に問題がありそうで再検してから申し上げるべ きだったが，今回のデータでは，8時間值も上昇する場合があつた．他の動物，同種の家鬼甲状腺で免疫し 矢張りLATS like activity を得た. 正常人甲状腺のみで免疫つづけたウサギは今迄やったととがない.

質 問：別府野口病院 佐藤 誠也 Mckenzie 法では正常ウサギの $\gamma$-globulin でも高濃度に濃縮して マウスに投与すると LATS 様反応を示すととがある。I ${ }^{131} \%$ increase が300\%以上でなければ non specific response である可能性が強いと考えている.

応 答: 京大第一内科 永田 格 Nonspecific かどうか慎重にとのととであるが, guinea pig antirabbit $\gamma$-G1 で中和されているので, てれは nonspecific なものと考えられる.

4. 甲状腺組織中の LATS 不活性化因子の分離, 精製に関する研究

別付野口病院 佐藤 誠也，野口 志郎，野口 秋人

甲状腺組織の細胞膜由来と考えられる LATS 不活性化因子 (LIF) の分離，精製法を検討した。組 織 homogenate の $25 \%$ 42\%硫安飽和沈渣を DEAE-column chromatography に吸着させ，0.04M sodium phosphate buffer (SPB) pH 5.9-0.4M SPB-1M NaCl と gradient elution を行なつた. LIF 活性は 
Thyroglobulin (TG) を含まない F2 (LIF-A 分画) と, TG を含む, F6, F7 (LIF-B 分画) と認められ た. LIF 活性の specific activity は硫安塩析分画で homogenate-Tris 抽出液の 3.5 6.0 倍, DEAE column の LIF-A 分画では 130倍, LIF-B 分画では F6 で 19.5倍, F7 で60倍であつた. 次いで LIF-A.B 両分画の各々 Sepharose 4B gel filtration を行なつたとてろ, A 分画は更に3つの分画に分離され, LIF 活性は F2 亿高率に抽出され, specific activity は320倍を示した. またB分画は 4 つの分画に分離された が，LIF 活性は TG を含まない F3，F4 亿認められ specific activity は各々62倍と58倍を示した。これら LIF 活性を示した各分画はアンスロン硫酸法で糖反応陽性を示したが， B 分画の 2 つのピーク (UV) は糖 では 1 つのピークのみ認められた. glycine buffer $\mathrm{pH} 12.0$ による沪紙電気泳動像はいずれの LIF 分画共 に Sudan Black 染色法で原点に留まり有意差は認められなかつた。複合脂質の分析結果ではA分画に 3 個， B 分画に 5 個の糖反応陽性スポットを検出しその中， 2 個のみ共通の Rf 值を示した。従つて糖脂質を含む Lypoprotein であることが今回も推察されたが LIF は DEAE column, あるいは gel-filtration の態度か らみて多様性である可能性が示唆され興味深い.

質問: 阪大第一内科 網野 信行 (1)先生の所でされた Mckenzie Bioasay をみると, 甲状腺抽出液 ないしは硫安分画をスライドでみると100 mg〜 $50 \mathrm{mg}$ を用いておられが, 私達の経験ではマウス一匹に甲状腺 ホモジネートないしは cell sap を 50mg 以上を入れると生理的条件を越えて, 正確な Bioassay が出来な いとの結果を得ているが，先生の所では実際にはどの様にやつておられるのか. (2)聞きもらしたかと思うが， 最終的に得られた分画が Thyroglobulin を含まないとのととだが，その同定の仕方はどの様にしたか.

(3) LATS 活性の中和能を各分離された分画につき，比活性をみておられるが，その比活性の出し方はどの 様にされたのか教えていただきたい.

応 答: 別府野口病院 佐藤 誠也 1) Protein 量で $200 \mathrm{mg} / 3 \mathrm{ml}$ serum まで, 可能である. 2) Cellulose acetate 膜電気泳動で Thyroglobulin の有無を検討した成績である。3) 各組織の homogenate (Tris 抽出液) 毎に standard LATS を中和して蛋白量当りの中和標準曲線を作製し，ての中和曲線より 各分画の purification factor を換算した.

5. サイロキシン生合成についての実験的研究（II）

阪大西川内科 瀬尾敬, 伊藤 周平, 毛利 俊彦, 西大条靖子, 西川 光夫

Thyroxine $\left(\mathrm{T}_{4}\right)$ 生合成のうち Diiodotyrosine (DIT) の縮合過程については今なお不詳である。 その 過程の間に Diiodophenylpyruvicacid（DIHPPA）を生じるという説はかなり有力である，最近私達は強 アルカリ性の条件下で, DIT + Pyridoxal $+\mathrm{Cu}^{++}$による nonenzymatic transamination 機作によりほぼ 10\%の DIHPPA を回収し得る事を報告した. 今回は生理的な条件下で種々の metal そついての DIHPPA 生成率を比較すると同時に, 牛甲状腺超遠心分画中の Tyrosine, DIT, 及び Monoiodotyrosine, (MIT) 飞 対する transaminase の存否を検討し, 更に non-enzymic 亿試験管内 $T_{4}$ 合成を試みた. DIHPPA 及び $T_{4}$ の同定はペーパクロマトグラフィー及び分光分析によつた。 DIT, Pyridoxal phosphate (PLP) 及び種々 の metal を $\mathrm{pH} 8.0$ の borate buffer 中で 1 時間室温放置後, DIHPPA 生成率を見ると, $\mathrm{Mu}^{++}$につ て約 $19 \%$ で最も多く, $\mathrm{Cu}^{++} 4 \%, \mathrm{Co}^{++} 2 \%$ でてれて次で, $\mathrm{Al}^{+++}, \mathrm{Ni}^{++}, \mathrm{Fe}^{++}, \mathrm{Fe}^{+++}$では殆んぞ認められ なかつた. Fisher らは MIT, Pyridoxal, $\mathrm{Mn}^{++}$及び $\mathrm{H}_{2} \mathrm{O}_{2}$ 産生系に牛甲状腺 microsome を加沉て diiodothyronine の生成を報告しているので, ほぼ同様の system で $\mathrm{Mn}^{++}, \mathrm{Cu}^{++}, \mathrm{Co}^{++}$そついて DIHPPA 生成率を見たが enzyme の添加はむしろ抑制的に働いた，又 metal を含まず $\alpha$-ketoglutarate を加えた系 でも同様であつた．次いで Blasi らの行なつた如く DIT と DIHPPA を含んだ $\mathrm{pH} 7.6$ の borate buffer 中に $\mathrm{O}_{2}$ を加える事により $\mathrm{T}_{4}$ を生ずる事を確めたので， DIT + $\mathrm{Ma}^{++}+\mathrm{PLP}$ を含んだ同様 buffer 中に $\mathrm{O}^{2}$ を添加して行くと約 4 時間後より次第に灰褐色に混濁して来た。 ての沈潵は遊離の $\mathrm{T}_{4}$ と, $\mathrm{T}_{4}+\mathrm{PLP}+$ $\mathrm{Mu}^{++}$の混合物と同定された。 以上 DIT より DIHPPA を生ずる step は生体内でも DIT $+\mathrm{PLP}+\mathrm{Mn}^{++}$ により nonenzymic 亿進行する可能性があり，それに酸素を加える事により試駼管内で DITより $\mathrm{T}_{4}$ が 合成される可能性がある事が確められた。 
質 問: 東大吉利内科 尾形 悦郎 $\mathrm{Mn}^{++} 0.83 \mathrm{mM}$ を用いた in vitro 実験で, nonenzymatic reaction に生理的意義をもたせているようだが，細胞内では， $\mathrm{Mn}^{++}$はそのほとんどが mitochondria などの intracellular structure に結合され，化学反応に必要な free $\mathrm{Mn}^{++}$の濃度はかなり低いものと考えられる. したがって，先生らの行なつた反応系に対する $\mathrm{Mn}^{++}$の濃度の影響，とくにてれがどてまで低下させるて とができるかまた甲状腺細胞でどの位の $\mathrm{Mn}^{++}$濃度が期待できるかおうかがいしたい.

応答：阪大西川内科 瀬尾 敬 $\mathrm{Mn}^{++}$濃度の変化による DIHPPA 及び $\mathrm{T}_{4}$ 生成率の変化は見て いない. 実験的に $\mathrm{Mn}^{++}$の甲状腺への取り込みが特異的に高いという成績がある. 又用いた $0.83 \mathrm{mM}$ $\mathrm{MnCl}_{2}$ は Fisher ら，乙の方面の研究者の用いているものより低濃度である.

6. 血中 thyroxine と Triiodothyronine の同時測定

長崎大高岡内科 和泉 元衛, 高村 邦彦, 宇佐 利隆, 高岡 善人 最近, Werner らは, 感度の高い Competitive protein binding analysis を用いて, 血中 $\mathrm{T}_{3}$ の測定が 可能と報告している。しかし，まだ大量の血清を必荘とするため, 我々は Werner 法を Modify し, 少量 の血清を用いて, 臨床的に十分使用出来る $\mathrm{T}_{3}, \mathrm{~T}_{4}$ 同時測定を検討したので報告した。血清 $2 \mathrm{ml}$ を $\mathrm{me}$ thanol : Chloroform で 2 回抽出, Sephadex Column LH 20 で精製し, paper chromatography (Sterling 変法）で，甲状腺ホルモンを分離した。 $\mathrm{T}_{3}, \mathrm{~T}_{4}$ の assay には Sephadex G25 $1.0 \times 6.0 \mathrm{~cm}$ column を用い た competitive protein binding analysis を行なつた. てれで得た standard curve は， $T_{3}$ で 0-10ng 間 で $20 \%$ の， $\mathrm{T}_{4}$ で0〜20mg 間で30\%の gradient で良好であつた。これら Standard curve は測定 range が狭いため, $\mathrm{T}_{3}, \mathrm{~T}_{4}$ を測定する場合, 問題となるのは, Ghromatography そ用いた paper の blank 值 である.我々は paper を methanol : ammonia (9:1) で洗涤するととにより, blank 值を negligibleに することが出来た。この方法による最終回収率は $\mathrm{T}_{3} 45.3 \%, \mathrm{~T}_{4}$ で $34.3 \%$ であつた. 再現性は, 相対標準 偏差で, $\mathrm{T}_{3} 12.1 \%, \mathrm{~T}_{4} 8.5 \%$ と良好であつた. 測定值：正常者 $\mathrm{T}_{3} 0.31 \pm 0.12, \mathrm{~T}_{4} 7.5 \pm 1.0$, Hypothyroid $\mathrm{T}_{3} 0.73 \pm 0.15, \mathrm{~T}_{4} 19.0 \pm 2.9$, Hypothyryoid $\mathrm{T}_{3} 0.14 \pm 0.06, \mathrm{~T}_{4} 1.3 \pm 0.4 \mathrm{r} / \mathrm{dl}$ で共に甲状腺機能をよく反映し ている. 次に同一 sample で $\mathrm{T}_{3}, \mathrm{~T}_{4}$ の相互関係を見ると，一見非常に良好な相関を認めたが， $\mathrm{T}_{3}, \mathrm{~T}_{4}$ の 比をとつて更に詳細に見ると，正常者 0.053, Hypothyroid 0.037,であるか, Hypothyroid は 0.119 と著明 な高值を示した。乙れは興味ある知見である。結語 $1 . \mathrm{T}_{3}, \mathrm{~T}_{4}$ の同時測定法を検討し, 感度, blank 值な ぞに改善を加えた結果, 血清 $2 \mathrm{ml}$ で良好な再現性が得られ, 臨床的に有用である。 2 . 血清 $\mathrm{T}_{3}, \mathrm{~T}_{4}$ 值は 共に，甲状腺機能をよく反映しているが， $\mathrm{T}_{3} ， \mathrm{~T}_{4}$ 比は，特に Hypothyroid では著明な高值を示す例があ り，今後検討すべき興味ある知見である。

質 問：阪大阿部内科 木村 和文 Hypothyroidism にて $\mathrm{T}_{3} / \mathrm{T}_{4}$ 比が高いという実験成績は興味があ る。我々は最近 analog computer を用いて，血中甲状腺ホルモンと結合蛋白の相互関係を Simulation 法 にて検討しているが，血中甲状腺ホルモン濃度が低いときは，TBP の $\mathrm{T}_{4}$ 未結合部分が増加し，その結果 Affinity の低い $\mathrm{T}_{3}$ が相対的に多く結合されるという現像が起ると考えられる. 従つて, 血中 total 量で みるとき，更に甲状腺より分泌される際の $\mathrm{T}_{3} / \mathrm{T}_{4}$ 比が一定であつても，血中比は高くなるととは当然尒想 できる。

質 問：別府野口病院 野口 志郎 Hypothyroid の場合 $\mathrm{T}_{3} / \mathrm{T}_{4}$ 比が大きくなるとの報告で湢るが， $\mathrm{T}_{3}, \mathrm{~T}_{4}$ 共に非常に少ない場合に測定の精度のわづかの差が，影響して来るのではないか. $\mathrm{T}_{3}, \mathrm{~T}_{4}$ が非常 に少ない場合の精度はどうか.

質 問: 天理病院 稲田 満夫 血中 Triiodothyronine の正常値は Werner の病院では平均 $0.33 \mu \mathrm{g} \%$ で只今の報告とほぼ同じですが，乙の正常值が最江測定法の改善により低くなり大体 $0.2 \mu \mathrm{g} \%$ と報告され ている，従つて $\mathrm{T}_{3}$ 測定法は更に改善検討されるべきである.

7. 各種病的甲状腺組織における Microsome 抗原の螢光抗体法による検索

東大第二外科 藤本 吉秀 東京医歯大病理 畠山茂 
各種の病的甲状腺組織について Microsome 抗原の有無を螢光抗体直接法により検索した。 その目的は, 甲状腺自己免疫現象の研究の一端として行なうということのほかに, 結果によつてはてれが腺腫様甲状腺腫, 腺腫，癌の間は鎰別診断の一助になる可能性を検討するとてろにある，方法：手術で摘除した甲状腺組織の 一部を直ちに凍結し, 厚さ $4 \mu$ の切片を作り, 四塩化炭素10分固定またはアセトン 2 分固定ののち, 橋本病 患者血清 $\left(\mathrm{PT}\right.$ 陽性, TRC $\left.\times 10^{6}, \mathrm{MGF} \times 2^{12}\right)$ より抽出した殊に FITG 標識を施したもので螢光体直接法 を行なつた。結果：甲状腺沪胞上皮の Microsome 抗原が最も強く染色されるのはバセドウ病組織である. バセドウ病でも症例によつて染色度に差があつたが，重症度，投与薬剤の種類と投与期間あるいは組織像と の間に特別の相関性:は見出せなかつた。橋本病に誤つて抗甲状腺剤を投与し機能低下症状を起した 1 例と, び漫性甲状腺堙を有し機能低下のある dyshormonogenesis の1例では, 前者が Microsome 抗原+, 後者 が土で, これら両者はともに TSH 過剩分泌があると考元られる例であるが抗原量には一定の傾向がみられ ない，逆に術前乾燥甲状腺未を投与していた腫暍例で, 腫暍以外の正常甲状腺組織の部分の抗原量を調べて みたが，てれが必ずしも抗原量の減少を示すとは限らなかつた．次に腺腫様甲状腺腫では，部位によつて著 しい増殖像のみがみられる所があるのが特徴であるが，その部の上皮の Microsome 抗原染色度は他の部に 比して特に変りは認められ学かつた。腫瘍では, 10 例の乳頭腺癌, 1 例の䯣様癌 1 例の Langhans 腫癔, 計12例の癌がすべて Microsome 抗原を欠如した。一方良性腺腫では，比較的よく分化した形態像を有する コロイド腺腫の 1 部のものが抗原欠如を示したのみで, あとは索状, 管状, 乳頭腺腫すべてに抗原が認めら れた．普通の病理組織検查で鑑別のむづかしい例にての方法を併用するとよいと考える。

質 問: 信大丸田外科 張 洛禹 1 . 橋本氏病患者からの採血量 2 . 螢光色素を標識する患者血清 には抗サイログロビリン抗体が含れていないか． 3．抗サイログロブリン抗体の除去法は，

応答: 東京医歯大病理 畠山 茂 使用した抗血清は, thyroglobulin 及び microsome の両方への 強い抗体活性を有している，従つて使用したラベル抗体による染色は，両者を染めうるものであるが，固定 差によつて染別した。即ち四塩化炭素, 及びアセトンによつて microsome を, メタノールによつて thyroglobulin を選択的に染色が可能である.

8. 欠 演

9. ヒト慢性甲状腺炎の電顕的並に螢光抗体法による研究

岡大大藤内科 鈴木 信也, 宮脇 昌二, 森田 実, 徳山 清公, 太田 善介

8 例の慢性甲状腺炎組織の電顕的観察を行なつた。散在性甲状腺炎の間質の浸潤細胞は主に成熟小リンパ 球であつた，リンパ球は沪胞内にも浸入するが，直接上皮細胞を障碍する徵候はない，時にリンパ球は胞体 突起を上皮細胞膜を破つて胞体内に突入させている．散在性甲状腺炎では上皮細胞の胞体内に多数のミトコ ンドリアが充満している。濔慢性甲状腺炎の好酸性変性上皮型でもミトコンドリアの多い細胞が出現するの が特長である，濔慢性甲状腺では形質細胞浸潤が主となり血中抗体価の高いもので，とくに顕著である．形 質細胞は沪胞上皮と時に密接するが沪胞内に浸入するものは少い。間質に形質細胞浸潤が著明なものでも沪 胞内に浸入するのはリンパ球である。濔漫性甲状腺炎では形質細胞浸潤にともない，均質な物質の上皮細胞 内沈着が起り上皮の変性は促進されるようである。螢光抗体直接法により抗 7S 及び 19S $r$-globulin conjugate で慢性甲状腺炎の組織を染色するとコロイド腔内及び汇胞外にも7S- $\gamma$-globulin の沈着を認めた．浸 潤細胞は多くは 7S- $\gamma$-globulin を保有していたが 19S 保有細胞もあつた. また 19S 抗体の沪胞上皮内沈着 も認められた。

追 加：信大丸田外科 広瀬 義明 私共は, 橋本氏病における沪胞上皮細胞の微細構造を追求した結果, 次の如き所見を得たので追加する。橋本氏病の沪胞上皮細胞の核は核縁が不整で，核質はしばしば不均一で， 核膜下に凝集する。乙のような核物質の不均一な凝集状態は, 私共の観察では正常甲状腺の生理的な老化細 胞にみられ, 更には自家融解性変化ないし, 実験的な傷害細胞に出現するものであつて一種の細胞変性を表 わすものと考光られる. 次に，てのような核の変性像よりも，細胞質の変性が先行して認められるてとから， 変性の発生は細胞質から始るものと考元られる。汇胞上皮細胞にわける細胞質の変性像は $\mathrm{M}_{+}$の異常な増加 
が， $\mathrm{M}_{+}$の変形及び $\mathrm{M}_{+}$と $\mathrm{Er}$ 間の構造崩㵙によつて表わされる. 即ち， $\mathrm{M}_{+}$の膜の一部が小湾入を起し てての部の内外膜が解離し, 相対する $\mathrm{Er}$ 膜が消失するため, $\mathrm{M}_{+}$が $\mathrm{Er}$ の腔内容に直接している所見が多 数認められ， $\mathrm{M}_{+}$と $\mathrm{Er}$ 間の構造崩䘫は， $\mathrm{M}_{+}$の基質, 即ち, 自己蛋白の放出を来たすととが推測される. 浸潤細胞に関しては，汇胞上皮細胞内にリンパ球，プラスマ球などの侵入像がみられ，スライド上はリンパ 球が小突起を形成して沪胞上皮細胞小器官と接している像，下はプラスマ球の侵入像である．また，沪胞腔 内には，リンパ球，プラスマ球の他に大型のマクロファージや自血球などがみとめられる．以上の $\mathrm{M}_{+}$と $\mathrm{Er}$ 間の構造崩壊あるいは侵入細胞の所見は，本症の病因論として有力視されている自己免疫を支持する 重要な所見と考えている.

質 問：群大内分泌研 黒住 一高 固定法は何によつておられるか. グルタールアルデヒドを用いると， ミトコンドリアに人工変化を抽すととが多いが，オスミウム酸単独固定ならば問題はないと思う.

追. 加：東大吉利内科 尾形 悦郎 演者は，沪胞細胞を直接 attack するのはリンパ球と形質細胞であ ると結論されたが，私達は慢性甲状腺炎患者血清（おこらく抗ミクロゾーム抗体）が直接沪細胞細胞に作用 するととをみている，乙の成績の一部はシンポシウムで鈴木が報告する予定ですが，体液成分も，沪胞細胞 を attack する因子の一つと考光る。なおとのとき観察される変化は練胞内 pyridine nucleotides reclox state の変化で，当然乏トコンドリアの機能変化も関係してくるものと思われる．したがつて， damage を うけたミトコンドリアより抗原がでてくるという可能性（追加者一丸田外科）以外飞，ミトコンドリアの変 化は，抗体の attack 結果ででもあるものと考える.

10. 甲状腺沪胞上皮細胞の増殖動態と機能に関する研究

信州大丸田外科 ○宮川信, 飯田 太, 降旗 力男

甲状腺沪胞上皮細胞の增殖動態と機能との関連を解明する目的で, ラッテに ${ }^{3} \mathrm{H}-$ Thymidine 及び ${ }^{225} \mathrm{I} \mathrm{Na}$ を投与し，経時的に甲状腺細織の Autoradiography を行ない観察した。まず甲状腺沪胞を便宣上，原始沪 胞, 中汇胞, 大沪胞の 3 群に分けて ${ }^{3} \mathrm{H}-$ Thymidine 標識細胞の出現状況を検討した。標識細胞は ${ }^{3} \mathrm{H}-\mathrm{Thy}-$ midine 投与後30分で各沪胞に認められ，中でも中沪胞に最も多く，ついで原始沪胞，大沪胞の順である。 しかしながら時間の経過と共に標識細胞は原始沪胞に少なくなり。大沪胞に多くなる傾向が認められた。 以 上の成績から，ラッテ甲状腺では， generative cell は各沪胞の上皮細胞の中に含まれており，原始沪胞と して新生した沪胞は，その中に含まれている generative cell の分裂により次第に大型の沪胞へと発育する ものと考えられる。甲状腺組織においては，一層の沪胞上皮細胞の中に混つて多層の上皮細胞か認められる ことがあるが，ての部の ${ }^{3} \mathrm{H}-$ Thymidine 標識細胞について検討すると，標識細胞は一般に多層上皮細胞の 基底部に多く認められるが，時として多首上皮細胞の上層部にも認められることがある。しかしながら経時 的に標識細胞の出現状況を観察すると，時間の経過とともに標識細胞は上層部にも多くなる傾向か認められ た．この成績から甲状腺の多層上皮細胞においては，generative cell は主として基底部に存在するが，上 層部にもわずかに存在し，乙れらの generative cell の分裂によつて新生した maturative cell が，上層部 へ移行するものと考光られる。つぎに ${ }^{125}$ I-autoradiograyhy の成續について述べると，原始沪胞をのぞく 全沪胞に ${ }^{125} \mathrm{I}$ の集績による黒化か認められ，中でも中沪胞に最も強く，大沪胞の黒化度は比較的軽度であ つた。すすなわち，甲状腺組織の中で ${ }^{125} \mathrm{I}$ 摂取能の最も強い沪胞は中沪胞で，ついで大汇胞であり，原始沪 胞は機能的役割をほんど果してないものと考光られる. 以上，甲状腺沪胞上皮細胞の增殖動態および ${ }^{125} I$ 摂取能に関する成績を述へた。

質 問：群大内分泌研 黑住 一昌 沪胞壁を斜切れた切片では，実際には単層であつても，多層にみ える可能性があると思います，㒈密には連絡切片について検討する必要があるように思われる。

応答：信州大丸田外科 宮川信 ラッテ甲状腺多層上皮細胞に対して，我々も，検討しましたが一 応，円形あるいは楕円形の沪胞を切つた場合一層であれば多層に見えることは非常にまれなものであると考 えすなおに多層上皮細胞と判断した。 
11. ${ }^{131} \mathrm{I}-\mathrm{T}_{3}$ Resin Sponge Uptake Test の低温 Incubation 法についての検討

\begin{tabular}{|c|c|c|c|}
\hline 放医研 & 土屋 & 武彦 & \\
\hline ダイナボットR．I.研 & 滝野 & 博, 倉田 & 邦夫, 分林 \\
\hline 伊藤病院 & 伊藤 & 国彦，西川 & 義彦，井野 \\
\hline 慶大浅野内科 & D百溪 & 尚子 & \\
\hline
\end{tabular}

${ }^{131} \mathrm{I}_{-} \mathrm{T}_{3}$ Resin Sponge Uptake Test は, 従来室温 1 時間 Incubation 法が使われ, 用状腺の機能程度を 無視して一律に， 5 分につき $1 \% ， 1{ }^{\circ} \mathrm{C} に つ き 10 \% の$ 補正が行なわれているが，実際には機能程度によつて 補正係数を変えなければ正しい值が得られているとは言えない。またての方法では, 冷蔵庫保存されてい た血清が，室温になるまでの時間の考虑も必要である，てれらの点を coverする方法として，我々は低温 長時間 Incubation 法を考え，良結果を得た。すなわち，poolしておいた用状腺機能圥進症の血清，機能 低下症の血清, および標準血清の 3 種の血清について, $2{ }^{\circ} \mathrm{C}, 5{ }^{\circ} \mathrm{C}, 8{ }^{\circ} \mathrm{C}$ 亿固定した室内, および $5{ }^{\circ} \mathrm{C}$ 亿 ットした冷蔵庫で, 20時間, 24時間, 28時間の Incubation を行なつて, Triosorb 摂取率を測定したと乙 ろ, この範囲であれば，温度補正の必要がなく，時間補正も 2 時間につき $1 \%$ て済み，促来の方法より時間 がかかるといら年はあるが，機能程度によつて補正を変えず安定した正しい值が得られることがわかつ た. また，血清の保存の温度と Incubation の温度が同じなので，その間に要する時間を考えなくてよいと いう利点もある。 そてで, 低温長時間 Incubation 法を, 冷蔵庫内 24 時間 Incubation 法と決めて, 正常人 97名，および，臨床的に甲状腺機能え進低下と診断された者それぞれ92名，40名につき，本法および，正確 に $25^{\circ} \mathrm{C} 1$ 時間 Incubate した場合で，Triosorb 摂取率を測定したととろ，両者にきれいな相関がみられ， 本法では機能が低い程，值の幅がひらく傾向がみられた．本法での Triosorb 捸取率の正範团は， $54 〜 67 \%$ であつた。なお, キトットによる補正汇関しても検討したが, 本法においても従来の方法同様, 補正の必要 性を認奴。

12. テトラソルブによる血清サイロキシン測定について

千葉大第一内科 小山 千明, 上野 高次, 穴沢 輝一, 内山 静則, 三輪 清三 我々は, 今度新たに開発された Tetrasorb 125 を用いて, 血中 thyroxin $\left(\mathrm{T}_{4}\right)$ を測定し, 従来行なわれ ている BMR, ${ }^{131}$ I-uptake, Triosorb などの検查と，てれを比較し，検討した．本法は先づ血清 $1 \mathrm{ml} 95 \%$ エタノールで抽出し, その上清の $0.3 \mathrm{ml} \mathrm{N}_{2}$ ガスにて乾燥した後, ${ }^{125} \mathrm{I}-\mathrm{TBG}$ を $1 \mathrm{ml}$ 加え, 更にレジレスポ ンジを挿入し，一定時間 Incubateし，その Ist Count と, 洗條後の IInd count との比を求め, その\%值 から, 既知濃度血清から得られた標準曲線を用いて, その被検血清のサイロキシン量を求め, それより得ら れた值を抽出に用いた溶媒エタノールの抽出係数 0.79 とり補正する。本法を用いての従来の BMR, ${ }^{131} \mathrm{I}-$ uptake, Triosorb Test との比較の結果は, BMR $+30 \%,{ }^{131}$ I-uptake $60 \%$ 以上の Hyperthyroid につい ては, 添附の標準曲線の $20 \mu \mathrm{g} / 100 \mathrm{ml}$ 以上を示す高濃度のものが多数見られた。 そこで, ての $20 \mu \mathrm{g} / 100 \mathrm{ml}$ 以上のものについては, 本法の上清 $0.3 \mathrm{ml}$ をピペットする点を $0.15 \mathrm{ml}$ 亿半減し操作した，その結果 $20 \mu \mathrm{g} /$ $100 \mathrm{ml}$ は越光なくとも, それに近い值で示されるととが分つた。したがつて, BMR, ${ }^{131}$ I-uptake, Triosorb Test の三者のうちで, 二者以上の検查結果が Hyperthyroid を思わせたならば, 検体を Duplicate 亿操 作方場合, 最初から同量で行なわず, $0.3 \mathrm{ml}, 0.15 \mathrm{ml}$ 亿分けて行なうことも一法である. ての点は更に多 くの症例について検討を加え報告したい. Euthyroid, Hypothyroid については三者との比較に於いて，ほ ほ満足せる結果を得た。尚, 各症例についての $\mathrm{T}_{4}-\mathrm{I}$ 值の範四は, Euthyroid 33 例中 $(4.3 \sim 9.9 \mu \mathrm{g} / 100 \mathrm{ml})$, Hyperthyroid 16例中（但し $20 \mu \mathrm{g} / 100 \mathrm{ml}$ 以上ものは省く）9.9 22.5 $\mu \mathrm{g} / 100 \mathrm{ml}$, Hypothyroid 6 例中 (0.S $\sim 5.9 \mu \mathrm{g} / 100 \mathrm{ml})$, Pregnancy 5 例中 $(15.6 \sim 25.1 \mu \mathrm{g} / 100 \mathrm{ml})$ であつた. (尚Pregnancy は本法との比較は $\mathrm{T}_{3}$ のみであつたが， $\mathrm{T}_{4}-\mathrm{I}$ 值は $20 \mu \mathrm{g} / 100 \mathrm{ml}$ の上界とそれを越えるものがあり， $\mathrm{T}_{3}$ とは逆であつた。）

追 加：阪大阿部内科 松岡 徹 血清 $\mathrm{T}^{4}$ の Ethanol による抽出は $95 \%$ ethanol そ1\%の割合で 28\% ammonia を加えると，約 $90 \%$ となり，95\% ethanol 単独で抽出するよりも良好な成績を得た。 
質 問 : 野口病院 佐藤 誠也 1) 私の経験では Lot No.によつて Abbott の Standard とよく一致 するものと，しないものとがあるままたよく一致するものでも保有期間が長くなると高値を示す傾向が認め られる。

応 答 千葉大第一内科 小山 千明 $0 \mu \mathrm{g} / 100 \mathrm{ml}$ にて常に高くなるととは, 洗條回数によるのではない かとのととだが，演者の洗滌回数は 4 回だつた。

質 問 阪大阿部内科松岡 徹 血中 $\mathrm{T}^{4}$ 值が高值を示す例で, ethanol 抽出液の $0.15 \mathrm{ml}$ と $0.3 \mathrm{ml}$ で測定した值の相関を検討されたか. 我々の検討成績では $13 \mu \mathrm{g} / \mathrm{dl}$ 以上では $0.15 \mathrm{ml}$ による測定值がやや高 く測定される傾向がみられた。

応 答: 千葉大第一内科 小山 千明 標準曲線とついて, $10 \mu \mathrm{g} / 100 \mathrm{ml}$ の点での, キット中の標準曲線 值と演者らとの一致回数を御指摘でしたが，23キット中18例だつた。しかし，(この18例はほとんぞ二つの 曲線に一致をみたので，他も $5 \%$ 内外で高く出てはいたが，5，10，15, $20 \mu \mathrm{g} / 100 \mathrm{ml}$ の各ブロットを満足し ていた.

質 問 : 別府野口病院 佐藤 誠也 1 ) 低温法でも Lot 差は解消出来ないとすると長時間を要する点 で必らずしも 1 時間よりも特に優れているとは教えられないが, 同一 pool 血清の daily variation は比較 されたか.

応 答: 千葉大第一内科 小山 千明 $20 \mu \mathrm{g} / 100 \mathrm{ml}$ 以上の Hyper についてのみ，上清液を $1 / 2$ 量 $(0.15$ ml）にした. Euthyroid については未だ行なつていないので次回に報告したいと思う.

13. Tetrasorb-125による甲状腺ホルモン測定に関する検討

金沢大がん研臨床部 斉藤 好正, 日置 長夫, 倉金 丘一

最近, Competitive protein binding analysis (CPBA) による各種ホルモンの測定法は重要性を増しつ つあるが，今回，甲状腺ホルモン測定用として市肘されるに至つた Tetrasorb-125につき，従来の化学的測 定法と比較してその得失を考察し, 次の結果を得た。1) Tetrasorb-125 による血中 $\mathrm{T}^{4}$ の測定は, 従来の 化学的測定法に劣らぬ精度を示した。 しかし, 測定操作に比較的時間を要しない反面, 全操作段階を通じて 厳密なる一定条件を保持すべき点, やや煩雑である，2）洗㣠回数は 4 回が適当であつた．3）ヨード含有 薬剤を夾雑した血清についても，再現性のある $\mathrm{T}_{4}-\mathrm{I}$ が簡易に測定可能である，4）TBG solution 中には TBG 分屑以外の若干の夾雑物の存在を認め，また製品番号により標準曲線にかなりの差異がみとめられた が, $\mathrm{T}_{4}$ の CPBA に関してはほぼ満足すべき結果が得られた。しかし精度の向上を目的として尚, 改良さ れるべき余地がある.

追 加：千葉大小児科 中島 博徳 Tetrasorb test の最大の問題点と考えられる. extract efficiency に関する改良点を追加する．1） $95 \%$ ethanol の代りに n-propylalcohol を用いて回収率を10\%程度増加 せしめた．2） ${ }^{131} \mathrm{I}-\mathrm{T}_{4} の$ trace を陚料に予め加える事によつて， extract efficiency と試料の測定を同時に 行ない，操作の簡易化及び extract efficiency のばらつきの欠点を完全になくすととができた。

14. テトラソルブ・キットを用いる血中サイロキシン測定法の臨床的応用

昭和大第三内科 飯野 史郎, 林 和德, 飯ヶ谷 清, 渡辺 隆, 大野 敏雄
由利弘一郎, 宮本 正浩, 伴 良雄

今回われわれは, 前回報告した方法にしたがつて, テトラソルブ・キットを用いる血中サイロキシン $\left(\mathrm{T}_{4}\right)$ 測定法の臨床的検討を試みたので, その結果を報告する。諸種状態における血中 $\mathrm{T}_{4}$ 濃度は, 正常人 (63例) では，平均值 $10.2 \pm 2.1 \gamma / 100 \mathrm{ml}(6.1 \sim 15.5)$ で，正常人男（23例）では $10.2 \pm 2.0 \gamma / 100 \mathrm{ml}(6.1 \sim 15.5)$ ， 正常人女（40例）では $10.3 \pm 2.1 \gamma / 100 \mathrm{ml} （ 6.2 \sim 14.5)$ であり，男女間には有意の差異は認められなかつた。 甲状腺機能穴進症 (32例) では， $27.5 \pm 7.6 \gamma / 100 \mathrm{ml}(15.2 \sim 43.8)$ ，甲状腺機能低下症（6例）では， 2.86 $\pm 1.7 \gamma / 100 \mathrm{ml} \quad(0.8 \sim 6.3)$, 妊妮 3 ケ月以後の妊婦（10例）では, $13.8 \pm 3.4 \gamma / 100 \mathrm{ml}(9.5 \sim 20.1)$, ネフロ

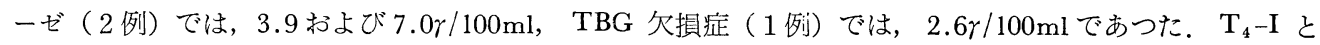
PBI との相関係数は $\mathrm{r}=0.93,{ }^{131} \mathrm{I}-\mathrm{T}_{3}$ resin Sponge uptake $\left({ }^{131} \mathrm{I}-\mathrm{T}_{3} \mathrm{RSU}\right)$ との相関係数は $\mathrm{r}=0.86,{ }^{131} \mathrm{I}-$ 
uptake との相関係数は $\mathrm{r}=0.77, \mathrm{BMR}$ との相関係数は $\mathrm{r}=0.72$ であつた. 甲状腺機能克進症患者を, メル カゾールを用いて治療した場合の血清 $\mathrm{T}_{4}$ 值の変動は, 同剤の量と共に減少し, ${ }^{131} \mathrm{I}-\mathrm{T}_{3} \mathrm{RSU}$ 值とほほ平 行していた。 甲状腺機能低下症患者を, サイロキシンを用いて治療した場合の血清 $\mathrm{T}_{4}$ 值の変動は, 同剤 を増量するとともに増加し， ${ }^{131} \mathrm{I}_{-} \mathrm{T}_{3}$ RSU 值とほぼ平行していた．甲状腺機能低下症患者を甲状腺末又は卜 リヨードサイロニンを用いて治療した場合の血清 $\mathrm{T}_{4}$ 值の変動は, 代謝が正常化しているにもかかわらず. 低值を示した. 血清 $\mathrm{T}_{4}$ 值は, ジフェニールヒダントイン又は, フェニールブタゾン投与により，低下する のが認められた。 以上の成績より，(1)血清 $\mathrm{T}_{4}$ は正常者から甲状腺機能九進症及び甲状腺機能低下症を鑑別 する上で極めてよい指標と考えられる。(2) TBG の巽常がある場合又は, 乾燥甲状腺末，トリヨードサイ ロニン, 或はジフェニールヒダントインやフェニールブタゾンの如き楽剤の投与を受けている場合には, 代 謝状態を知る上での指標とはなりがたい. (3)血清 $\mathrm{T}_{4}$ 值が $13 \gamma / 100 \mathrm{ml}$ 以上を越える場合は，精度の低下を来 たすためアルコール抽出液の $1 / 2 \sim 1 / 3$ とつて測定する事が望ましい.

追 加：長崎大高岡内科 和泉 元衛 Tetrasorb 測定に関する追加をする. 第 6 席で報告した, $\mathrm{T}_{4}$ 測 定法に従い，同一血清を tetrasorb と共に測定した data をおみせする，又スライドねがいます，即ち， 我々の方法は抽出, 精製, 分離により specifity の高いものであり, Tetrasorb の精製, 分離がないため, 全測定值共に高值をみている。乙とに Hyperthyroidism, 及び, Normal では非特異的な夾雑性を一部側定 していることを示している。しかし tetrasorb 法でも, Hyperthyroid, normal, Hypothyroid と各群の分 離は良好で, 臨床的には， $\mathrm{T}$ 分有用なととを示している。なお，本法の一部は，甲状腺同好会にて御報する 予定である。

追 加 岡大小坂内科 湯本 泰 Tetrasorb の測定と同時に free $\mathrm{T}_{4}$ iodine free $\mathrm{T}_{4}$ concentration の測定を行なつた, Pregnat 及び decreased TBG について free $\mathrm{T}_{4}$ iodine, concentration は正常である が Preg では TBG, TBPA の增加を来しており又 decreased TBG については TBG は少い. よつて Tetrasorb は Thyroxine binding protein に異常を来す状態及び薬物投与に際しては free thyroxine concentration と比例せず正しい甲状腺機能を現わさない.

質問：虎の門病院内分泌科，紫芝 良昌 1) Diphenylhydantoin は通常の保田氏では PBI に変動を 与えないてとが報告されている. 全回の発表の data で, $153 \mathrm{mg}$ Diphylhidantoin 投与で, 下つたてとは, 何回もくり返されて, Validity を check されたか.（第14席に対して）2）Lot に添附された橿準曲線と， 実測された標準点とのずれは, どの程度, あるものであろうか.

応 答: 昭和大第三内科 渡辺 隆 ジフェニールヒダントインの血清 $\mathrm{T}_{4}$ 濃度におよぼす影響につい ては, $60 \mathrm{mg} /$ 日, $100 \mathrm{mg} /$ 日，および，153 $\mathrm{mg} /$ 日の 3 種の量について，3例において検討致し，何れも $\mathrm{T}_{4}$ 濃度は低下する傾向か認められた。

15. 血中 Triiodothyronine の測定（第 2 報）

正常人，甲状腺機能九進症及び機能低下症における血中 Triiodothyronine 值及び

Triiodothyronine Degradation Rate そついて

天理よろず相談所内分泌内科 稲田 満夫, 葛谷 英嗣, 風間 善雄, 高山 英世 我々は昨年内分泌西日本地方会（昭和43年10月）で Werner らによる血中 Triiodothyronine (以下 $\mathrm{T}_{3}$ ) 測定法の基礎的検討につき報告した.今回は Sterling らの方法を検討し，この方法は比較的簡単で信頼性 のある測定法と考えられた。 そこで Sterling らの方法を用いて, 正常人, 甲状腺機能圥進症及び機能低下 症の血中 $\mathrm{T}_{3}$ 值を測定すると共に ${ }^{131} \mathrm{I}$ 標識 $\mathrm{T}_{3}$ 代謝実験より， $\mathrm{T}_{3}$ Degradation Rate (以下 $\mathrm{T}_{3} \mathrm{DR}$ ) の 算出を試みたので，その成績を報告する. Sterling らの方法による血中 $\mathrm{T}_{3}$ 值は正常人（18例）平均 $0.21 \pm$ 0.06 (SD) $\mu \mathrm{g} \%$, 甲状腺機能穴進症 (21例) 平均 $0.65 \pm 0.24$ (SD) $\mu \mathrm{g} \%$ 及び機能低下症（ 5 例）平均 0.08 $\pm 0.03(\mathrm{SD}) \mu \mathrm{g} \%$ で疾患間に重り合いはなく, よく甲状腺機能を反映した．次に血中 $\mathrm{T}_{3}$ 值と Tetrasorb Kit による血中 Thyroxine (以下 $\mathrm{T}_{4}$ ) 值を同一血清で測定し, 両者の関係をみると例の Masked Hyper- 
thyroidism で $T_{4}$ 亿比し $T_{3}$ 值は高值な傾向を示し，之等症例で $T_{3}$ の重要性を示唆した。 之等特殊な 症例を除くと正常人, 各種甲状腺疾患で血申 $\mathrm{T}_{4}$ と $\mathrm{T}_{3}$ はほぼ平行して変化し, 両者間に直線関係 $(r=+$ 0.90) があり， $\mathrm{T}_{3}=0.033 \times \mathrm{T}_{4}+0.066(1)$, なる式が得られ，血中 $\mathrm{T}_{4}$ 值より值が推定された。更に正常人 (4 例) 甲状腺機能六進症 ( 8 例) 機能低下症 ( 2 例) $\underbrace{131} \mathrm{I}$ 標識 $\mathrm{T}_{3}$ を静注投与し, その血中 ${ }^{131} \mathrm{I}$ 濃度 減衰曲線より $\mathrm{T}_{3} \mathrm{DR}$ を算出した。 $\mathrm{T}_{3} \mathrm{DR}$ の正常値は $21 \pm 7 \mu \mathrm{g} / \mathrm{day}$ で, 我々が先に報告した Thyroxine Degradation Rate $\left(\mathrm{T}_{4} \mathrm{DR}\right)$ の正常值 $(81 \pm 8 \mu \mathrm{g} / \mathrm{day})$ のほぽ1/4であつた。 こてで $\mathrm{T}_{3}$ の効力は $\mathrm{T}_{4} の 4$ 倍とすれば，正常人で Total Metabolic Effect の半分は $\mathrm{T}_{3}$ Metabolism によると考えられた. かくして, 正常人で血中 $\mathrm{T}_{3}$ 值は $\mathrm{T}_{4}$ 值のほぼ1/30であつたがその Metabolic role は $\mathrm{T}_{4}$ と同等で $\mathrm{T}_{3}$ の重要性が 認められた。 $\mathrm{T}_{3} \mathrm{DR}$ は甲状腺機能穴進症平均 $86 \pm 31(\mathrm{SD}) \mu \mathrm{g} / \mathrm{day}$, 機能低下症 $5 \mu \mathrm{g} / \mathrm{day}$ で $\mathrm{T}_{3} \mathrm{DR}$ は血 中 $\mathrm{T}_{3}$ 值とほほ直線関係 $(\mathrm{r}=+0.95)$ を示し， $\mathrm{T}_{3} \mathrm{DR}=169 \times \mathrm{T}_{3}-8$ (2) なる式が得られた。こてに式(1)及 び(2)より $\mathrm{T}_{3} \mathrm{DR}=5.577 \times \mathrm{T}_{4}+3.154$ が得られ，血中 $\mathrm{T}_{4}$ 值を測定する事により $\mathrm{T}_{4} \mathrm{DR}$ は勿論 $\mathrm{T}_{3} \mathrm{DR}$ の算 出も可能であつた.

質 問: 虎の門病院内分泌科 紫芝 良晶 1) MGR を single injection 以外飞 constant infusion で やられた成績があるか，2）MGR 自体は，Hyperthyrodism, Hypothyroidism 正常人で類があるかどうか. 応答: 天理病院 稻田 满夫 1 ) 甲状腺機能により $\mathrm{T}_{3} の$ Metabolic clearance rate (MCR) は変 化するが Thyroxine のそれほど著明でない。

質 問: 東大中尾内科，長滝 重信 咋年の国際内分泌学会で Woeber, Ingbar は彼らの求めた $\mathrm{T}_{3} の$ fractional turnover rate や distribution space と Nauman らの求めた $\mathrm{T}_{3}$ 濃度から計算すると $\mathrm{T}_{3} の$ Degradation は $\mathrm{T}_{4}$ と同し位になると報告していた様に思う. 先生の報告された $\mathrm{T}_{3}$ 濃度が Sterling ら の方法と同しとしるすと Nauman の $\mathrm{T}_{3}$ の1/2位であるので, $\mathrm{T}_{3}$ の Degradation $\mathrm{T}_{4}$ の $1 / 2$ 位にな るのではないかと思う。しかし先生の今日の報告では $1 / 4$ 亿なっている様であるが Woeber らの計算と比べ て方法のどての部分が異るのか.

16. 甲状腺ホルモンとカテコールアミンの相関に関する研究

甲状腺機能充進症患者の外因性カテコールアミンに対する反応を中心にして

岩手医大木村内科 木村武, 井上一䇙, 及川 量平, 安達敏昭, 大島 健一 甲状腺機能亢進症患者にノルアドレナリンの持続点滴を行ない, 血圧, 脈搏, 血糖, 乳酸および FFA 值 の変動を指標とし, 正常者との反応の差異から甲状腺機能え進症におけるカテーコルアミンの役割を推論し ようとした。対象および方法：甲状腺機能充進症息者 5 名, 甲状腺機能低下症患者 2 名, 正常者 8 名を対象 として実験を行なつた。甲状腺機能充進症患者においては入院時, レセルピン投与後, メルカゾール投与あ るいは外科的治療により症状軽快したのちの 3 回経過をおいながら実験を行なつた。ノルアドレナリン点滴 は30分間で総量 $229.26 \mu \mathrm{g}$ を注入し, 注入前, 注入後 15 分, 30 分, 注入中止後 30 分, 90 分と計 5 回採血し, 血糖，乳酸，FFA 值を測定した。結果および考挍 : 無治療時の甲状腺機能九進症患者の外因性ノルアドレ ナリンに対する反応は正常者と比較すると血厓昇が著しかつたが，血糖，乳酸わよび FFA 值の変化は 正常者と差異がなかつた。メルカゾール投与㐋を行ない症状軽快した甲状腺機能克進症患者におけるノルアド レナリン投与による血圧の上昇は無治療時の変化と差異がなかつたが，外科的手術を行なつたものでは，， ルアドレナリン投与を行なつても血圧上昇せず正常者とかわらない変化を示した．以上の結果より甲状腺機 能六進症におけるカテコールアミンの役割は循環器系の問題と代謝系の問題を分離して諭をすすめるべきで あり,さらに甲状腺機能六進症においては自律神経系の六進状態が存在するてとを推測せしもると共に外科 的手術を行なつたもののみで血反の上昇が認められなくなる事実は自待神経系の六進状態をきたす原因が甲 状腺自体江存在するという印象をうける。

応 答: 岩手医大木村内科 井上一彦 後肢灌流法を用いて筋肉内ホスホリラーゼ活性を指標として行 なつた実験, 心筋内ホスホリラーゼ活性を指標として行なつた実験において甲状腺ホルモンとカテコールア ミンはなんらの協力作用を有しなかつた事実，さらに今回の実験結果よりとの両ホルモンの甲状腺機能六進 
症における役割を考えていく上で代謝系の問題と循環器系の問題を分離して考朰ていかなければならないと 考觉ている。

17. $\mathrm{KClO}_{4}$ による無機ヨード放出試験についての検討

北大真下内科 武内 恵輔, 山本 豊, 上田 峻弘, 堀内 淑彦, 真下 㤵明 ヨード制限時に $\mathrm{KClO}_{4}$ による ${ }^{131} \mathrm{I}$ 放出試験を行なう時, ${ }^{131} \mathrm{I}$ 放出が認められない甲状腺のヨード有機 化の部分的障碍を少量無機ヨードを ${ }^{131} \mathrm{I}$ tracer と同時に経口投与する方法によつて検出しうることを実証 した。 1）正常人に mercazol $10 \mathrm{mg}$ を 3 日間前処置した時, ヨード制限の条件において $\mathrm{KClO}_{4}{ }^{131} \mathrm{I}$ 放出 試験を行なつたとてろ， ${ }^{131} \mathrm{I}$ の放出はみられなかつた，2）同様の前処置をした条件で KI 液として無機 ヨード $0.5 \mathrm{mg}$ を carrier として ${ }^{131} \mathrm{I}$ tracer と同時に併用する時, $\mathrm{KClO}_{4}$ 投与 1 時間後の甲状腺からの ${ }^{131} \mathrm{I}$ 放出率は $34.8 \pm 10.6 \%$ で有意の放出がみられその時の甲状腺には無機ヨード有機低過程に partial defect が存在しているととを示した。 3) mercazol の前処置なしに無機ヨード0.5 mgを仿用した $\mathrm{KClO}_{4}$ 放出試験 で $\mathrm{KClO}_{4}$ 投与後 ${ }^{13} 1 \mathrm{I}$ の放出はみられず 2 ）にみられた結果は甲状腺に摂取された併用無機ヨードのため 生じた急性抑制効果によるものではないと推定される，4）無機ヨード $2.0 \mathrm{mg}$ 併用 $\mathrm{KClO}_{4}$ 試験で ${ }^{131} \mathrm{I} の$ 放出は見られない，5）TSH 10U を24時間前に筋注し同様の試験を行なつた。用状腺 ${ }^{13} 1 \mathrm{I}$ 摂取率は増加を 示したが，無機ヨード併用の条件のみでは $\mathrm{KClO}_{4}$ による ${ }^{131} \mathrm{I}$ の有意の放出はみられず， mercazol 前処置 した場合，故出率 $60.3 \pm 7.9 \%$ を示した。 6) 無機ヨード $0.5 \mathrm{mg}$ 併用侍の PII, AIU を測定した。 てれらの 值は mercazol 前処置の有無によつて差を示さなかつた，7）慢性甲状腺炎，単純性甲状腺腫患者に無機ヨ 一ド併用 $\mathrm{KClO}_{4}$ 放出試験を行ない，その有用性を示した．以上から甲状腺に潜在する無機ヨードの有機化 の部分障碍の微少である場合は，ヨード制限では $\mathrm{KClO}_{4}$ 試験により検出されず，少量の carrier ヨードを 併用した $\mathrm{KClO}_{4}$ 試験で摂取された無機ヨードが甲状腺内有機化能の capacity を飽和し $\mathrm{KClO}_{4}$ の投与に より ${ }^{131} \mathrm{I}$ が放出され，有機化の partial defect を確認しうるものと推論した.

質 問：虎の門病院内分泌科 紫芝 良昌 1 ) 正常人に mercazol を前処置して，0.5 mgのヨードを加 え， ${ }^{131} \mathrm{I}$ を投与して， perchlorate を用いなかつた例があるかどうか，質問の理由は，橋本病などでは，ヨ 一ドを同時に投与するだけでも discharge がおてり，軽度な有機化障害のある場合，ヨード投与のみによつ

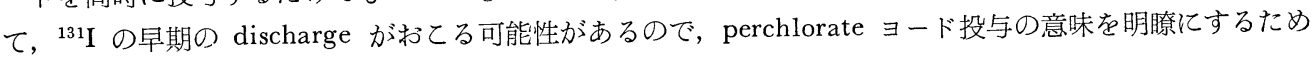
に必要であると思う。

応 答: 北大真下内科 武内 恵輔 Carrier Iodide を投与後 3 時間， 4 時間の uptake を測定した場合 uptake curve が下行型となる可能性はあるが，症例にわける検討はまだしてない.

18. 人甲状腺のヨード含有量とヨードアミノ酸分布との関係

東大中尾内科 長滝 重信, 中尾 喜久 東京保藤病院 伊藤 国彦

人間の甲状腺内でのヨード代謝を調べるととを目的に，摘出した正常甲状腺組織についてョード化合物の 分析を行なつた。術前の処置としては 2 週間海藻類を制限した群と， 2 週間海藻類を摂取させた群の両方に 手術の 4 時間前に ${ }^{131} \mathrm{I}$ を，24時間前に ${ }^{125} \mathrm{I}$ を投与し，摘出した甲状腺の ${ }^{125} \mathrm{I} ，{ }^{13} \mathrm{I} I ，{ }^{127} \mathrm{I}$ の量を測定したの である．先づ放射性ヨードの組織への％uptake は勿諭海藻類摂取群で著明に低下していたが，以前から 本学会でも報告しているように ${ }^{127} \mathrm{I}$ 摂取量は逆に增加しているものと考觉られる。次に放射性ヨードの各 ヨードアそノ酸への分布を調べると, 海藻類制限群でもホルモンである, $\mathrm{T}_{4}, \mathrm{~T}_{3}$ は $1 \sim 2 \%$ 亿すぎず, これは他の動物に比へて非常に少なく，人間ではホルモンの turnover は非常にゆつくりしているものと考 えられ臨床的にホルモン生成障害の有無を判定する上に注:意すべき点と考える。海藻類摂取群では MIT の \%が高いのが特徵的であつた．乙のように放射性ヨードの代謝は海藻類摂取によつて非常に異るのに化学的 に測定した甲状腺内の有機ヨード量は両者に有意の差はなくアミノ酸分布にも差は認められなかつた。次に てれらの甲状腺内の化学的に測定したョードアミノ酸量を甲状腺内の総ヨード量, あるいは thyroglobulin のヨード化の割合と比較すると Edelhoch らの in vitro の成績と非常によく一致し、ヨード化の割合が多 
くなるにつれて DIT が増加してくる.しかしててで注意すべきてとは海藻類を与えても, 制限しても甲状 腺のヨード量あるいは thyroglobulin のヨード化の\%は正常な甲状腺では in vitro の実験のように大きく 変化するととはない，即ちホルモン生成のコントロールは主として各ヨードアミノ酸の turnover rate の 変化によつて行なわれると考えられ，てのことは我々が今まで発表してきた動物実験の結果ともよく一致す るのである。

質 問: 天理病院 稲田 満夫 (1)正常甲状腺内の $\mathrm{T}_{4}$ と $\mathrm{T}_{3}$ 量の比及び(2)その比が投与ヨード量によ り変化するか否かを問う。

応 答: 東大中尾内科 長滝 重信 今日の患者は海藻類制限 5 名, 海藻類摂取群 15 名で海藻類摂取群は 大体 1 日10〜30mg位のヨードを攝つていると考えられるが，特に14日位では $\mathrm{T}_{3}$ が多くなるととはない様 で両群とも $\mathrm{T}_{3} / \mathrm{T}_{4}$ は $1 / 5 \sim 1 / 6$ だつた。 但しネッ゙ミでは 1 日 $500 \mu \mathrm{g}$ のヨードを 4 週間投与すると $\mathrm{T}_{3} / \mathrm{T}_{4}$ は有意に上昇していた。

質問：阪大第二内科 伊藤 周平 実際動物実験又はホルモン生成障害に甲状腺内有機ヨードアミノ酸 の分布をみると時，RI 使用時には何時間後に thyroid tissue をとり出して検索するのがよいとお考劣か.

応答: 東大中尾内科 長滝 重信 radioactive iodine による equilibration technique は Van Middlesworth 以来 evaluation の程度が時と共に変化して来ている様ですし実験のどれ位前に isotope を 与えれば良いかということも非常に困難だと思います，従つて chemical な測定の可能な場合は出来るだけ chemical に測定した值を使うことにして radioactive iodine は turnover rate, metabolic rate を見るこ とを目的として使用するというのが良いのではないかと思う。

19. 少量の抗甲状腺剤と無機ヨード併用時に見られた甲状腺ヨード代謝異常

群大第一内科 ○国吉南海夫，下田 新一，七条小次郎

少量の抗甲状腺剤をラッテに投与し甲状腺におけるホルモン合成を不完全に抑制した場合ヨード効果がど のように現われるかを調べる目的で，高ヨード食（200〜300 $\mu \mathrm{g} / \mathrm{kg} ）$ で飼育した体重約 $150 \mathrm{~g}$ のッテに 0.1 mg MTU (Methylthiouracil) を投与し， 5 分後に 1，10，20及び $100 \mu \mathrm{g}{ }^{127} \mathrm{I}$ を復腔内に注射した。更に 60 分後 $10 \mathrm{mg} \mathrm{NaClO}_{4}$ を投与し 30 分後にラッテを屠殺し, $\mathrm{NaClO}_{4}$ 投与前後の甲状腺 ${ }^{131}$ 摂取率を測定し 比較した。 $1 \mu \mathrm{g}{ }^{127} \mathrm{I}$ 一投与群の明状腺 ${ }^{131} \mathrm{I}$ 一の約 $25 \%, 10 \mu \mathrm{g}{ }^{127} \mathrm{I}$ 投与群では約 $30 \%, 20 \mu \mathrm{g}{ }^{127} \mathrm{I}$ 一投与群でン は約 $55 \%$ そして $100 \mu \mathrm{g}^{1}{ }_{7}^{7} \mathrm{I}$-投与群では $95 \%$ が血中に放出された. 少量の抗甲状腺剤で甲状腺におけるホルモ 合成能を不完全に抑制した条件下では更に少量の ${ }^{127} \mathrm{I}$ 一を追加投与するてとによりヨード化タイロシン特に Diiodotyrosine の合成が MTU 単独投与群よりも強く抑制された。このてとが MTU と ${ }^{127} \mathrm{I}^{2}$ を併用する ことにより甲状腺内に $\mathrm{NaClO}_{4}$ で甲状腺より血中に放出されるョード量の增加している原因と考えられる。 MTU 量を $1.0 \mathrm{mg} / \mathrm{Rat}$ 以上僧量するとかかるる ${ }^{127} \mathrm{I}$ 一の抑制作用はみられない.

20. 甲状腺機能充進症の自覚症状について

別府野口病院 ○野口 志郎, 村上 信夫, 野口 秋人 バセドウ氏病の治療にあたり，治療後甲状腺機能は完全に正常になつているにもかかわらず，自覚症状の みがいつまでも残つている患者があり悩まされることがある。この問題について若干の psychosomatic な 検討を加えたので報告する. Cornell Medical Index を使いバセドウ氏病104例と広義の神経症36例の自覚 症状を調べた。その自覚症を深町の方法によつて判別するとバセドウ氏病の $51.9 \%$ ，神経症の $91.7 \%$ は neurotic または provisionally neurotic 亿分類された。バセドウ氏病では病悩期間の長いものほど神経症 的傾向が強いてとが㥨められた。 バセドウ氏病と神経症の自覚症状は質的には概ね同じであり，両疾患の自 覚症の順位相関係数は0.783であつた。無作為に抽出したバセドウ氏病44例について, 治療前と治療後甲状 腺機能が完全に正常になつて $3-6$ ケ月後に自覚症状を同様に調べた. 全体的に自覚症状の数は減少してい たが, その減少の程度は病悩期間の短いものほど著明であつた。自覚症状は治療前と非常に類似順位相 関係数は 0.995 であつた. よつてバセドウ氏病は早期に適切な治療を行なうことが必要であると同時に, 
psychosomatic な配慮が必要であると思われる.

追 加: 東大中尾内科 末松 弘行 私共も CMI を用いて調查した. 対象は甲状腺機能六進症50例, そ の他の甲状腺疾患25例, 正常対照者25例の計100例で, 全例女子である. 結果は $\mathrm{CMI} の \mathrm{III} \sim \mathrm{IV}$ 領域すなわ 5 neurotic と判定される率は, 甲状腺機能六進症では $44 \%$ で正常対照にくらべ高い. (他の甲状腺疾患の 40\%にくらべると有意差はない，）CMI の深町判定法では, 循環器系の自覚症状や, 易疲学性があると, より neurotic であるとされる. 従つて疾患の organic な面での症状に影響されるととがあるので, 慎重で ありたいと思う。しかし初診時機能充進症状の著明な群, 抗甲状腺剤で control された状態, 更に ${ }^{131} \mathrm{I}$ 療 法により機能低下になつた群にわけてみても neurotic の率が, 同様にみられるてとから, 甲状腺機能穴進 症の神経症的傾向は, 甲状腺ホルモンの影響のほが, 一つの性格傾向として認められるものと考えられる. てれが病前性格としてあつたものか，慢性疾患のために発病後に形成されてきたものか，問題であるが，い づれにしてもPsychosomatic な考慮も必要であると考光られる。

21. 甲状腺機能充進症における肥満について

九大第二内科 賀来 昌義, 平田 幸正, 近藤 重信, 丸山 俊之 渡辺斌, 伊東 三夫

80 人の甲状腺機能六進症に対して, その発症時の体重の変化について調査した. この80名のうち21名に体 重の増加をみた。即ち男 21 名に体重の増加をみた。即ち男 21 名中の 3 名, 女59名中18名が体重増加をみた. 体重の変化には性差と共に年令による差異もあるようであつた，とくに，30才未満の女性では，21名中11名 に体重増加があり, このうち 6 名は発症後に $5 \mathrm{~kg}$ 以上もの体重増加があつた。 栄養士による面接にて一日 の摄取カロリーを検討して, 甲状腺機能方進症患者にわける体重の増減を摂取カローリの関係を比較検討し た。体重増加群では一日平均 1946 カロリーの摂取, 一方体重减少群では平均 1946 カロリーであつた。経口 ブドウ糖負荷試験で，体重增加群は，糖負荷後の血糖が高值を示した。これに反して，ての際の血中インス リンの反応は增加群と減少で差異を認めなかつた。

質 問: 東京医大内科 大塚 舜一甲状腺機能克進症の患者で体重增加する例は我々も経験しています が，乙れに関してたしかに患者の摂取するカロリ一量も大切な要素と思うが，ての疾患では胃腸障害を起す 例が多いので, 胃腸の状態も体重増加に関係があると思われるが，てれについても検討されたか.

質 問: 天理病院 稲田 满夫 体重增加群と減少に於ける場合に患者が発病して診断をうける時期によ り異なると思うが，その点どの様にして分類しておられますか.

22. 抗甲状腺剤投与中止後の ${ }^{131} \mathrm{I}$ 甲状腺摂取率の回復

群大第二内科 石井 淳 甲状腺機能六進症患者につき，抗甲状腺剤を投与すると ${ }^{131}$ I 甲状腺摂取率は速かと抑制されるが，その投 与中止後, 摂取率の抑制が何日位続くかを調べた。 45 例の患者について 2 週間沃度含有食物の摂取を禁止し た後, 先づ ${ }^{131} \mathrm{I}$ 摂取率を測定し, 更に念の為追跡量の ${ }^{131} \mathrm{I}$ を再度投与して, ${ }^{131} \mathrm{I}$ 摂取率を計 2 回測定して 薬剮投与前値とした. 次いで propylthiouracil 1 日量 $300 \mathrm{mg}$ づつ, 又は少数例では methylmercaptoimidazole $30 \mathrm{mg}$ づつ，21日間連続投与した所 ${ }^{131} \mathrm{I}$ 㨫取率は直ちに抑制された。更に抗甲状腺剤投与中止の前 日から連日新たな追酶量の ${ }^{131} \mathrm{I}$ を追加投与しつつ, 1 日 1 回 ${ }^{131} \mathrm{I}$ 甲状腺椇取率を測定して, 薬剤投与中止 後の摂取率の回復状態を測べて見た。，回復迄に 2 日を要したものが20例（44.4\%，3 万至 4 日を要したも のが16例 $(35.6 \%) ５$ 乃至10日を要したものが 7 例 (15.6\%), 第11日目になつても摂取率が治療前値に戻 らなかつたものが 2 例 $(4.4 \%)$ あつた. 尚, 抗甲状腺剤投与前值よりも, 投与中止後一時的に攝取率の上 昇したもの（所謂 rebound phenomenon）は45例中 9例（20\%）に見られた。.以上より，抗甲状腺剤（主 として propylthiouracil, 少数列で methylmercaptoimidazole) を 3 週間投与して, その中止後 4 日目に は全体の $80 \%$ の例で ${ }^{13} 1 \mathrm{I}$ 甲状腺摂取率が投与前值に復帰し, 中止後10日目には全体の $95.6 \%$ の例で摄取率 回復が見られた事が判つた。尚，全体の $20 \%$ の例で rebound phenomenon が見られた事は，抗甲状腺剤 
治療中一時休薬して ${ }^{131} \mathrm{I}$ 甲状腺拉取率を測る際に，又は抗甲状腺剤治燎を行なつて来た患者につき，その 治療を断念して ${ }^{131} I$ 療法に切り換える際に, 注意する必要がある.

質 問：岩手県立中央病院 栗原 英夫 抗甲状腺剤投与中にもかかわらず，比較的高い $\mathrm{I}^{131}$ 摂取率を 示した症例はないか.

応 答: 群大第二内科 石井 淳 ${ }^{131} \mathrm{I}$ 甲状腺摄取率は propylthiouracil, 投与後大部分の例で, 比較 的速かに $10 \%$ 以下迄抑制され，何時までも，例光ば30\%位までしふ摄取率が低下しないといつた様な例は， ての45例については一例も見られなかつた。

応答：群大第二内科 石井 淳 出来れば実際に臨床で遭遇する様に propylthiouracil 数ヶ月間投 与した時に，その中止後どうなるかを調べなかつたが，患者を長期間㛜密な意味で follow up する事は容 易でないので，今回は一応条件を単純化する意味で，投与期間を同一にしてすべて 3 週間とした。 ての研究 で PTU を 3 週間投与した時にどうなるかを知る事は出来るが，長期投与の時もその様になるかどうかは， やつて見ないと判らない，今後検討して見たい問題である.

23. バセドウ病を伴なえる周期性四肢麻瘦の 3 例

岩手医大第一外科 ○佐々不 純, 䖦井 賢司, 谷川 武史

周期性四肢麻痺は発作性に四肢および駆幹の䟝緩性麻瘏を来す比軽的稀な疾患で，しばしば甲状腺機能立 進症と相伴なつて現われる事が知られている，我々は最近バセドウ病に伴なつた本症を 3 例経験したので報 告する，症例 1 は 34 才男子， 7 年前より多量の含水炭素摄取後に四肢麻瘦を来す様になり，次第に発作頻回 となる. 来院 1 年前より心悸六進, 眼球突出, 甲状腺腄等バセドウ病の症状出現す. 大量のブドウ糖静注に より四肢弛緩性麻瘦, 血清カリウムの低下を来す。メルカゾル投与後, 甲状腺典全剔出術施行す. 術後イン シュリンとブドウ糖併用による誘発試験を試みた所，麻痺に続いて著るしい徐脈，症攣，意識消失を来した。 $\mathrm{KCl}$ 静注により恢復したが，インシュリンは時に危険であると思われた。症例 2 は41才男子, 症例 3 は 30 才 男子, いずれもバセドウ病の症状発現に前駆して, 四肢麻瘏発作があり, いずれもブドウ糖負荷により麻瘦 が出現し，血清カリウムは低下す。両症例とも甲状腺亚全剔出術後四肢麻瘦も軽快した。

質 問: 天理病院 稲田 满夫 3 症例の甲状腺組織像は如何でしたか.

応 答: 岩手医大第一外科佐々木 純 甲状腺の組織像はすべて Struma colloides papillaris てリン パ球の浸潤はない。

質 問：虎の門病院内分泌科 紫芝 良昌 1) 自然発作時, K濃度の低下があまりみられないのは, Artifact である可能性はないか. 我々の約 30年の経験では麻痺中の低下は，ほとんど $3 \mathrm{mEq} / l$ 以下である. 応答: 岩手医大第一外科佐々木 純 採血時期は大体, 全麻瘴が起つた時に採血している. 採血後血 清を分離する時期は少し遅れたのもあつたかも知れない。

24. 周期性四肢麻痺に関する臨床的研究（第 5 報）

甲状腺中毒性周期四肢麻瘦発作時の血中インシュリンの増加

虎の閒病院内分泌科京大中尾内科 紫芝 良昌, 鎮目 和夫, 清水多恵子, 久野則一郎

インスリン注射又は過食，飲酒など外因性又は内因性インスリン増加させるような操作を行なつた場合に 上く起るてとが知られている，従つて，麻痺発作時内因性インスリンが増加しているてとが尒想されるが， 自然麻瘦発作前から麻瘦中にかけて，血中インスリン濃度を測定した成績がない，我々は，本研究で，用状 腺中毒性周期性四肢麻盘の 6 例に対して，食事のスケジュールを一定にしておき，麻瘦を観察しながら 4 時 間おきに採血して，IRI，HGH グルコース，Na，K を測定し，同時に100gグルコース経口投与に対する影 響を調べた。 6 例中 2 例に 3 回の麻瘦が観察された。 1 例目は, 麻痺前 IRI $50 \mu \mathrm{U} / \mathrm{ml}$ であつたのが，グ ルコース 100 g負荷により $200 \mu \mathrm{U} / \mathrm{ml}$ まで上昇し，その後も $100 \mu \mathrm{U} / \mathrm{ml}$ の值を続け，磨痺前には $500 \mu \mathrm{U} / \mathrm{ml}$ までの高值を示した。生長ホルモンは麻痺と関連ある変動を示さず，発作中はKの低下がみられた。第 2 日 
目における麻㿁中の IRI の変動も同様である。第 2 例では, 麻痺前 $75 \mu \mathrm{U} / \mathrm{ml}$ 以上の值が 4 時間以上持続 した. HGH は麻痺と関連ある変動を示さなかつた. 麻瘏発作を起さなかつた 4 例では, インスリンの増加 は軽度であるか, 又は持続時間が短く 4 時間以下であつた。麻痖を起した例では, グルコース $100 \mathrm{~g}$ 偩荷, 又は，食事に対して，インスリン濃度が増加し易い傾向がみられた。我々は甲状腺中毒周期性四肢麻瘏の 6 例について, 麻瘏の起る前に血中インスリンの持続的増加がみられること, 麻盘のない例ではインスリンの 持続的増加がないてとを明らかにし，インスリンの壃加が麻痺の「引き金」になるという大塚ら（医雬大薬 理）の説を支持する結果を得た。

質 問: 京大第一内科 永田 格 甲腺マヒの発作誘発, 又は「バ」病に対し, exogenous Insulin は ぞう影響するでしようか.

質 問: 聖ルカ国際病院 橘 敏也 本疾患が男性に多いととと, 演者等のいう Insulin 過剰分泌と の関係についてどうお考觉か.

質 問: 東大吉利内科 尾形 悦郎 paralysis の患者では, insulin 分泌の feedback regulation に異 常があるように思えるわけだが, glucose 以外の刺激, たとえば glucagon, secretin 等に対する insulin 分必反応にも異常がみられるか。

質 問 : 聖隷浜松病院内科 竹内 正幸 前の本会で周期性四肢麻痺に高張ブドウ糖を一定条件で静注す る際，麻瘏発現例では糖点静中すでに血糖值の低下を見るととを報告した，ての際われわれもインスリンの 過剰分泌を想像したのであるが，ての点非常に興味深く拝聴した. 今回の報告は自然発作時のインスリンの 動態について検討されているが，高張ブド一糖点静による麻瘏発現時の動態について検討されているか.

応答：虎の門病院内分泌科 柴芝 良昌 (1)男と女での差について 女性ではこのような試験を行なつ ていないので, 分からない. (2)グルカゴンその他のインスリン provoker をやつたかという諸氏に対して， アルギニン, グルカゴンなどで麻瘏がおてるかどうか. まだ施行していない. (3)グルコース負荷を静注で行 なつた際, 四肢麻盘の起る例はインスリンの上りがわるいのではないかという質問に対して, 本研究では oral glucose のみであり静注法に関する検討は行なつていない.

25. 甲状腺機能六進症の ${ }^{131} \mathrm{I}$ 療法の遠隔成績について

京大中央放射線部 森田 隆司, 森徹, 鳥塚 莞爾 京大第二内科 小西 漫二

昭和 41 年未迄に当内科にて ${ }^{131} \mathrm{I}$ 療法を実施した症例を可能な限り来院せしめて，本療法の遠隔成績の調 查を奏施し，昭和41年に同様に実施した調査とその成績を比較した。昭和41年末迄の治療総数は351例で, 昭和 43 年夏に来院せしめて実際に診療し得た症例は186例で，うち治癒例は128例 $(70.3 \%) ，$ 機能低下例 32 例 $(17.6 \%)$ であり, 治療年次例の機能低下発生率は年毎の増加傾向が見られた。 ${ }^{131} \mathrm{I}$ 治療後の血中 LATS 活性陽性率は経過年数と共に低下を示す一方，年と共に TSH 型反応陽性率の上昇が認められた。 TRG 抗 体陽性率は長期の観察では著しい変動を見せず，GF 抗体陽性率は経過と共に漸次低下の傾台を示したが， 両抗体共に治瘺群と低下群との間で陽性率に有意の差は認められなかつた。昭和41年夏にも同様な調查を実 施し，その際は89例が来院し，その症例は全て昭和 43 年度調査に来院しており，41年，43年調査における機 能低下例の発生頻度を, 治療年次別に比較を行なうことにより, その 2 年間に於る機能低下の発生の模様を 把握し得ることになる。その 2 年間の変動に於いては, ${ }^{131} \mathrm{I}$ 治療 4 年〜 7 年の症例に機能低下の著明な増加 が見られ，それは ${ }^{131} \mathrm{I}$ 治療後主として 4 年〜 7 年に機能低下の発生が多く起ることを示唆するものと思え た. この 2 年間の血中 LATS 活性, TRG 抗体価, GF 抗体価の変動を検索し得た症例は 33 例で, この 2 年間に新たに機能低下に陷つた 5 例のうち 3 例は治療後 4 年〜 8 年にあり，いづれも血中の甲状腺刺激物質 は筫反応より TSH 型反応に変化を示した。 43 年調查時計生検を施行し得た甲状腺組織のうち, 治癒例は多 少の間質反応を伴う colloid 型を示し，再発例は沪胞上皮の高度な増殖像を，機能低下例は間質の著しい線 維化の像を示した。

質 問: 名大第一内科 石突 吉持 $I^{131}$ 診療時に於ける年令が機能低下発症に影響を及ぼしたと考えら 
れないか，換言すれば年令によつて $\mathrm{I}^{131}$ に対する感受性に差異があるのではないか。 質 問 : 金沢大第二外科 長治 達雄 ${ }^{131} \mathrm{I}$ 療法後に於いて機能低下を来たした例に於いて, 甲状腺疾患 以外の疾病, 特に脇癌等の癌の発生傾向が有る様に思われるが何如か.

質 問：野口病院 野口 志郎 治䝤後 4 年から 7 年の間飞 Hypothyroidism が増加したと言うが，そ の間に治療法の重大な変化または治療対象の選択規準に大きな変化はなかつたか.

質 問：阪大第一内科 網野 信行 LATS 陽性血清に TSH を加えて Bioassay で測定すると, LATS 単独の時より, 反応\%が低くなるという G. Burk らの成績があるが, 先生の所の症例で LATS と TSH の共存すると考えられる血清のデーターを示されているが, その際 LATS の活性が TSH の増 加と共に低下して来たスライドをお示しだが，上記の理由により LATS 活性が低下したと断言するのは危 険だと思うが，どう考えておられるか。

応 答：森田 隆司 1) LATS 活陽性率性が ${ }^{13} I$ I 治療後次第に低下するてとの意味については, 機能 六進症の病因と共に不明である, LATS 型反応, TSH 型反応の陽性率についての判定には問題ないと思う. $2)^{131} \mathrm{I}$ 治療後 4 年〜 7 年に低下例発生率が多いというととは昭和 41 年, 43 年の両年に同一症例を誩療して, その 2 年間に正常甲状腺機能より低下に陌つた症例が多く見られたという意味であり, 今後同一症例につい ての follow up をつづけるととにより，より明らかになるととと考える．3）機能尣進症と他の自己免疫 疾患, 又甲状腺疾㭧との合併は多い, しかし我々の遠隔成績では, ${ }^{131} \mathrm{I}$ 治療を始めててれ迄の成續では死亡 例 7 例で, その内わけは, 脳出血 2 例, 胃癌 1 例, 肝癌 1 例, 急性白血病 1 例, 腩結核 1 例, 不明 1 例であ つた. 4 ) 機能低下症発生の年令別の調查では, 高年令程その発生率の高い傾向が認められた. しかし治療 率は年令別の差は認められなかつた。

26. 甲状腺機能六進症における脂質代謝 第 3 報 血漿脂酸の治療による推移

信大丸田外科 寺島 文平, 宮崎 忠昭, 村松 昭, 降粸 力男 信大中央検査部 金井 正光

第41および42回日本内分泌学会において, 甲状腺機能方進症の血漿脂質の量ならびそ脂酸構成が対照と比 較して明らかに変化しているてとを報告した．今回はてれらの脂質量ならびに脂酸構成比の外科的治療によ る推移を報告する.測定法は前回と京様である. 結果 1 ) 未治療時には, 血漿総脂酸量, 中性脂肪量, リ ン脂質量および総コレステロール量は減少しているが, 抗甲状腺剤の投与により增加し, 手術後 1 カ月では ほほ正常となる。一方血墏 NEFA 量は, 未治療時には增加しているが, 手術後 1 カ月では減少し正常値と なる。2）末治療時には, 脂酸構成比は総脂酸, 中性脂肪, リン脂質およびコレステロールエステルでは, パルミチン酸, ステアリン酸およびオレイン酸が增加し, リノール酸が減少しており, NEFA ではパルミ チン酸, ステアリン酸およびリノール酸が減少し, オレイン酸が増加している. 外科的治療によって, NEFA の脂酸構成比は正常になるが, 他の脂質の脂酸構成比では, なおパルミチン酸およびオレイン酸が 増加し, リノール酸が減少しており正常にならない. 結語, 甲状腺機能六進症の血漿脂質量は, 手術後 1 力 月には正常になるが, 脂酸構成比は正常になりにくく, 特にリノール酸の減少が特徽的である.

27. 甲状腺機能元進症と Adrenergic receptors

札幌医大宮原内科 宮原 光夫, 飯村 攻, ○菊入 剛, 阿部 久雄, 県 賢 森口修身, 浜上 裕一

甲状腺機能充進症における心血管異常を主として交感神経受容体の面から検索した. 対象は本症患者28例, 正常対象37例. 安静時, isoproterenol (IP. $0.02 \mu \mathrm{g} / \mathrm{kg} / \mathrm{min}$ ) 静注時, propranolol (Prop. 10mg) 静注15分, phentolamine (PA. $0.1 \mathrm{mg} / \mathrm{kg}$ ) 筇法15分, Prop. 後 IP 又は noradrenaline (NA. $0,3 \mu \mathrm{g} / \mathrm{kg} / \mathrm{min}$ ) 静注時 の心拍数 (HR), RISA を用いた体外計測法による, 心係数 (CI), ならびに一回拍出量 (SVI), capacitance plethysmography により, 前腕筇肉血流量 (FMF), 皮膚血流量 (FSF) を測定した。安静時本症で は HR の増加とそれに伴う GI の有意な増大をみる. FMF, FSF，も有意に高い，IP 投与時の HR， CI， 
FMF, FSF，の増加の程度は本症では有意に大きく，且つ Prop による HR, GI, FMF, の減少の程度も本 症で有意に大きい，次に PA によるこれら諸值の変化は対照と差がないまた NA による昇圧度，全未梢 抵抗の増大は本症では著しいが，Prop 後 NA 投与時の諸值の変化は対照と差をみない. 以上より本症の 心血管異常の少くとも一部は交感神経 $\beta$ 受容体機能立進に基く事が示唆された.

28. 甲状腺疾患の外科的治療時における甲状腺ホルモン動態

東北大第二外科 石井 隆志

目的：甲状腺疾患の手術及び麻酔の術中術後に及ぼす内分泌学的影響をみた。研究方法：232例（甲状腺 族患 186, 非甲状腺疾患46例) 飞つき疾患別, 麻酔法別 (ether, GOF， $\mathrm{N}_{2} \mathrm{O}$, 局麻) に PBI， I I31-T ${ }_{3}$ RSU (Triosorb test) を術直前, 術中, 術直後及び術後 7 日まで経時的に検索した。 方進症では両側斘状腺覀全 摘出術, 結節性甲状腺腫では片葉切除又は核出術を行なつた. 甲状腺以外の手術例を対照とした. 前投薬に 硫酸アトロピンのみを用い, ether 群でははじめにIII期吕相まで導入した， GOF 群はフローセン $0.5 \sim 1.0$ \%で維持し $\mathrm{N}_{2} \mathrm{O}$ 群では筋弛緩剂を用い極く浅い状態に維持した. 静脈麻酔剤は併用しなかつた. 結果 : (1) 六進症; ether 群では術前值に比して術中 PBI, (平均) $+48 \%$, Triosorb (平均) + $135 \%$ と増加した. $\mathrm{N}_{2} \mathrm{O}$ 群, 局麻群では術中の堌加はなく術後 1 ～病日に有意の増加を示す. GOF 群では術中術後共軽度増 加を示した。術後の体温, 脈拍数の変動は $\mathrm{N}_{2} \mathrm{O}$, 局麻群では脈拍数が他の群に対して有意の増加を示した. (2)結節性甲状腺腫 : 術中の変動は亢進症と同様であり, 術後もすべての麻酔群で増加を示したが, 臨床症状 に影響はなかった。(3)対照; 術中の変動は甲状腺手術例と同様であつたが術後病日の測定值の増加は全くな かつた，断案：(1)術中の血中甲状腺ホルモン増加は疾患, 術式に関係せず, 麻酔法に関係する. (2)術後第 1 ～第 3 病日にみられる増加は, 甲状腺の手術的侵襲に関係する. (3)穴進症では笑気局麻等の浅い麻酔及び手 術操作が術後反応を大きくする。 (4)術前高い相関 $(r:+0.84)$ を示した PBI と Triosorb 值が術中, 術 後にかけて相関の程度が低くなり（ $\gamma:+0.56 〜+0.34 ）$ これ TBP, TBC の変動を推測させられ今後の 検討を要す.

質 問：弘前大麻酔科 松木 明知 われわれも数年前から麻酔及び手術侵襲に対する影響について約 300 例の手術患者を対像に検索して来た。詳細は一昨年, 昨年の総会に発表したのでそれを見て載ければ幸 いである。そこで二つ質問させて載きたい，1）麻醉と手術侵襲の影響はお示しのデータにはないようであ るが，麻酔剤によつてかなり差異があります。エーテル，フローセン麻酔とペントレン，サイオペンタール 麻酔では全くパターンが異ります。２）次に術後の反応についてであるが，反応がつよいものと低いものと があるが，ての差について教えて載きたいと存ずる。

応答: 東北大葛西外科 石井 隆志 (1)口演中にも述べた通り甲状腺機能正常で甲状腺以外の手術を行 なつたものでも術中の血中甲状腺ホルモンの変動は甲状腺手術例と同様で, しかも各麻酔群の特徴を示して いるので，乙れは手術侵襲以外の因子即ち麻酔法の影響が考えられる。（しかも $\mathrm{N}_{2} \mathrm{O}$, 局麻群ではいかなる 手術でも術中值の増加はほとんどみられない)。(2)機能症では, その症状の程度別検討は行なわず, 研究対 象はすべて術前機能正常としたものである.

追 加: 野口病院 ○野口 志郎, 佐藤 誠也 特に術後血中甲状腺ホルモン増加の mechanism そつい て甲状腺機能六進症の 22 例について術後の血中甲状腺ホルモンの変化について調べた. 術前 1 時間, 術後 6 時間および24時間目に採血し PBI，および Thyroxine $\left(\mathrm{T}_{4}\right)$ を測定した。また 3 例に血中 Thyroglobulin を測定した。. PBI は測定した22例中 13 例に $\mathrm{T}_{4}$ は 6 例に増加を認めた。 そのうち 6 時間值の方が 24 時間値 よりも高かつたのは PBI, $\mathrm{T}_{4}$ ともに1例のみであり, 他は全て 24 時間值の方が高かつた. 血中 Thyroglobulin を測定した 3 例ではいづれも著明な増加を認めた。血中 $\mathrm{T}_{4}$ の増加と甲状腺の大きさ, 切除量, 残量, 病悩期間，年令等とはいづれも一定の関係は認められなかつた. 甲状腺の組織所見との関係では大濾胞性の もの 6 例中 5 例に, 大中滤胞性のもの 5 例中 1 例飞 $\mathrm{T}_{4}$ の増加を認めたが, 中滤胞性, 中小濾胞性および小 滤胞性のものを合せた11例では $\mathrm{T}_{4}$ の増加を認めたものはなかつた．とのととから術後の甲状腺ホルモンの 増加は, 残つている甲状腺組織から甲状腺ホルモンまたはそれを含んだ Peptide, Thyrogobulin 等が漏出 
するために起るものと考えられた。

29. 脊椎麻酔, 硬膜外麻酔及び手術侵襲の甲状腺

副腎皮質機能に及ぼす影響

弘前大麻酔科 松木 明知, 柴田 晋, 尾山少

71人の手術患者に春麻，硬麻を施行し，その甲状腺一副腎皮質機能に及ぼす影響を血清サイロキシン濃度 及び血漿コーチゾル濃度を推標として検索した。改麻では高比重 3\%の Quatacain 及び Lidocain を, 硬 麻では $2 \%$ Quatain, Lidocain を局麻剤として使用した。血漿コーチゾル濃度に関しては春麻前は $14.0 \pm 1.6 \mu \mathrm{g} / 100 \mathrm{ml}$ (Quatain)，15.1土1.6 $\mu \mathrm{g} / 100 \mathrm{ml}$ (Lidocain) であつたが，手術侵襲が加わつて15分たつ と各々 $18.6 \pm 1.7 \mu \mathrm{g} / 100 \mathrm{ml}, 17.9 \pm 0.4 \mu \mathrm{g} / 100 \mathrm{ml}$ と有意の堌加を示したが，血清サイロキシン濃度はほとん ど影響が見られなかった，硬麻群でも脊麻群とほとんど同じ傾向を示した。また両群においても甲状腺機能 （血清サイロキシン）及び副腎皮質機能（血漿コーチゾル）の間には相互的又は相反的な関係は見られなか つた.

30. 術後反応と血中甲状腺ホルモン

東大石川外科 稻垣 秀生

手術後には蛋白, 脂質など諸代謝の无進, 酸素消費量の増加, 体温, 脈搏数の上昇が来るが，乙れらの変 化にどの程度甲状腺ホルモンが関与しているかは，いまだ解明されていない，そのおもな原因は，今迄に PBI, Cholesterol をど甲状腺機能検査中の個々の值を示標としたためと考えられる。われわれは甲状腺機能 妄進症，胃癌，甲状腺腫痬および抗甲状腺剤投与中の患者の手術前後における free thyroxine index $\mathrm{I}^{31}$ thyroxine の生物学的半減期, 酸素消費量, 体温, 脈搏数の変化を検討した。 その結果, 術後には free thyroxine index の増加， I ${ }^{131}$-thyroxine 代謝の亢進があり，てれらと酸素消費量の増加および，恐らく体 温，脈搏数の上.昇との間に相関関係に近い密接な関係のあるとと，および抗甲状腺剤は上述の術後における 諸変化をある程度抑制できる可能性のあることが分つた。

31. DIT 脱ヨード化障害の臨床的検討

千葉大小児科 藤森 宗徳, 中島 博徳, 新晃 仁男, 堀口 東司, 爪生 東一 首村 紀夫, 久保 政次

本テストにより DIT 脱ヨード化障害と診断したものは26名（思12，女14名）で，甲状腺腫性クレチン 3 名, euthyroid goiter 10名, 甲状腺腫のない euthyroid 13名である. 10家系で, うち3例は優性遺伝を示 した. 2 時間までの ${ }^{131}$ I-DIT 尿中排泄率は 1.04〜21.65\% dose である. 本症は DIT が尿中に失なわれ， 内因性のヨード欠乏を来たす結果，甲状腺腫，甲状腺機能低下症を生じると考えられている．そとでョード， $\mathrm{T}_{3}$, Desiccated Thyroid を投与したが, 理論的に効果あると思われるョードでは甲状腺腫の縮少又は消失, 甲状腺機能の改善はみられなかつた。 $\mathrm{T}_{3}$ 又は Desiccated Thyroid では効果がみられている。本症が単な る BIT 脱ヨード化障害のみによつて，甲状腺䭪又は甲状腺機能低下を来たすとするには疑問が残ると思わ れる. Thyroglobulin の水解によつて生じた Diiodotyrosine は, 甲状腺及び全身の臟器にある DIT 脱ヨ 一ド化酵素により脱ヨード化される．先天性にこの酵素に異常がある場合 DIT は尿中に失なわれる。この 酵素の全身性の活性を静注した ${ }^{131}$ I-DIT の代謝により現在までに約150例について検查した。同一患者に DIT の量を変えて本テストを行なうと，DIT の多い時のほうが DIT の排泄率が多い．健常小览に種々の 量の DIT により本テストを行なうと，DIT の量の多い場合に DIT 排浛率が多いものがあつた。従つて 本テストを行なう場合 DIT の量を一定にすることが必要であるととを知つた. DIT $10 \mu \mathrm{g}$ 以下の条件下で の正常者 34 人の成績では ${ }^{131}$ I-DIT 尿中排泄率（2 時間）と尿中での ${ }^{131}$ I-DIT ( 1 時間) の比率は正の相関 を示した。（相関係数 0.75） 2 時間までの ${ }^{131}$ I-DIT 排泄率の $2 \sigma$ (95\%部分）は $1.1 \%$ dose で，ての值を 越えるものを異常とした。疾患別の排泄率では正常者群と差をみなかつた。

質間：京大第二内科 日下部恒輔 (1)脱ヨード障害だけでクレチン症が来るかどうかについては疑問を なげかけている文献もある．脱ヨード障害と同時に有機化障害をも合併している症例を呈示されたが，二つ 
以上の久損があるときその脊後に甲状腺蛋白の異常があるのではないかという事が考えられるので，その方 からの御検索をもお願いいたします。（2)内因性ヨード久乏とはいうもののヨードを投与してもヨードの turnover rate は依然として早いままでありましょうし，しかもそれが TSH を介するものであれば甲状腺 腫の縮小はあまりおてらないのであろうと思われる。やはり治療には甲状腺剤が必要と思う。

応 答: 千葉大小児科 藤森 宗徳 (1)報告した26例及びその他について Thyroglobulin の異常水解に 関しては直接検討していない. しかし26例については PBI の高值がなく，血中抗体も証明されなかつた. (2) ヨード無効飞関しては Querido 等も同様に Turnover rate が早くなるから DIT の尿中漏出が多く, 内因性ヨード欠乏の結果機能低下症には甲状腚腫を生じるとしているようである。しかし, 過剩にヨードを 投与すれば, ヨード欠乏を奶げると考光, 検討してみた次第である. ヨード・プールの問題, TSH の問題 などと関係して複雑であるが，DIT 脱ヨード化障害が未知の酵素障害のあらわれである可能性もあると考 える。

応 答: 千葉大小児科 中島 博徳 只今の $\mathrm{PBI}$ と $\mathrm{T}_{4}$ の相関についての疑義に関しては $\mathrm{T}_{4}$ を $\mathrm{T}_{4} \mathrm{I}$ そ直せばその差は少くなつているので問題はないと思う。

32. 成人性粘液水腫の精神症状

聖路加国際病院内科 橘 敏也, ○篠田 智璋

過去 10 年間の本院での粘液水腫は 33 例であつた，その内訳は，年令の点ではいずれも中年以降で，そのう ち, 女子が27例で, 約 8 割をしめ, 男子は 6 例であつた。 甲状腺機能低下の性質分類としては, 慢性甲状腺 炎によるものが18例，乙の中で，甲状腺腫を伴わないもの14例，伴うものは 4 例である。甲状腺術後性のも のは 2 例， I ${ }^{131}$ 治療後性のものは 2 例，その他，原因不明の，甲状腺腫を伴わず，甲状腺生検を行なわなか つた，いわゆる本態性粘液水腫は11例で, 計33例である，粘液水腫が示す臨床症状としては，浮腫，倊怠感， 貧血, 脱毛, 難聴等の身体所見の他に, より重要なものとして, 精神機能の異常を示すととが, 一つの特徴 と考えられているが，今回我々は，乙れら33例について特にその精神障害について検討を行なつたので報告 する. 精神機能低下として, いわゆる “減動” 即ち非積極性, 気力の低下, 無精, 彷順, 更に進行して, 無 気力, 無反応等の症候がみられ, 次いで, 精神障害として, 錯乱, 幻覚, ソーウッ状態が認められ, 症例の中 には, 当初, あたかも純然たる精神疾患を思わせるものが認められた。最後に, 精神機能低下の身体的表現 として, 動作緩慢, 僚念感, 脱力感, 易疲学性, ねむけ等が認められた。ささて, てれらの症候の転帰は, い ずれも一過性で, 甲状腺剤の服用により改善を示し, たとえ精神障害を来たすといつても, 疎通性を全く欠 く事はなく, いわゆる精神病のそれとは異なるものと考光られる. 次に, 脳波所見と症候の推移には密接な 関係があり， $\alpha$ 波の徐波化か症候の改善と平行して，正常化し，又 $\theta$ 波が症候増悪時に一過性に認められる 点, 興味深い, 粘液水埂の精神症状は, 非特異的で時には精神笑患, 神経症, 精神身体症等にも認められる もので，そのためにてれらの疾患と見誤られ易いので，充分に留意すべきである。

質 問：京大第二内科 日下部恒輔 (1) myxedematous coma の症例はあるか. (2) EEG のクレチン症 との比較はされたか. (3)機能低下症の患者を治療して euthyroid になつたかどうかという判定はかなり難 しい場合がある. EEG の正常化が来てはじめて euthyroid と言えるという文献もあるがての点如何か.

応 答: 聖路加国際病院内科 篠田 智璋 (1)レチニスムスがあつたかについて, 私共の症例はいずれ も中等以降であつたので, 経験例はなかつた。 (2)脳波との関連について, 今回, 私共は, 甲状腺機能改善と 脳波改善との関係よりも, 特に精神機能の変効, 改善と, 脳波の変動とに相関がられたたで, ての点, 精 神障害を有するものでは，ある程度脳波検索の意義があるのではないかと考える。

33. 慢性甲状腺炎の血清蛋白像と甲状腺自己抗体に関する研究（第二報）

信州大丸田外科 野村 節夫, 宮島 徳介, 降旗 力男 37例の慢性甲状腺炎について流血中の自己抗体と血清免疫グロブリンを測定し，それらの関係を組織学的 にも榆討した。実験方法，抗サイログロブリン抗体の検出には TA-test, 抗マイクロゾーム抗体の測定には Kolmer 法による補体結合反応を用いた。血清の IgG， IgA，IgM の測定は一元平板免疫拡散法を用いたい 
実験成績 抗サイログロブリン抗体は37例中17例に陽性で, 第一報で甲状沪胞上皮の好酸性化の有無より 2 群に分けたが，抗体は好酸性化群で陽性率が高かつた，抗マイクロゾーム抗体は37例中33例に陽性で，好酸 性化群はほとんぞが陽性を示し且つ抗体価も著しく高かつた。また間質のリンパ球系細胞浸潤の強いもので は GF 抗体価も高かつた。免疫グロブリン濃度は IgG では37例中 22 例が高值を示したが, IgA や IgM はほぼ正常範囲にあつた。また IgG は特に好酸性化群で高く, また IgG 漘度は血清 $\gamma-\mathrm{G}$ 分画や CF 抗体 価と明らかな相関を示した。

質 問 : 虎の閒病院内分泌科 紫芝 良昌 1 ）バセドウ病で $\mathrm{GF}$ 抗体価が陽性のものの組織像の特徵は ぞうか. 2) TA test は陽性又は陰性の基準のみで定められたか.もしそうならば， titer が不明なので，抗 サイログロブリン抗体の関連はあまり明瞭に出来ないのではないか.

質 問：東大吉利内科 鈴木 秀郎 われわれも数年前免度グロブリンと抗体価の関係を検討したが，一 般に $\gamma$-G の大部分は抗 thyroglobulin 抗体と考えられる如き成績をえている。したがつて GF 抗体価と $\gamma$ - G の量に相関がみられたという成績は納得しにくい，抗グロブリン抗体価との哭係を再倹討願いたい.

追 加：信州大丸田外科 張 洛禹 組織診断の確定した橋本氏病患者血清で螢光抗体間接法による自 己抗体検出率は $100 \%$ であつた，反応の揚を正常甲状腺組織と甲状腺機能充進症の甲状腺組織とに分けて検 討してみると前者では主に沪胞内コロイドに，後者では特に上皮細胞に強に螢光を見るてとができ，慢性甲 状腺炎の患者血清には抗コロ.イド抗体ならびに抗マイクロゾーム抗体の両者が存在するものと考えられ，野 村等の成績と一致したので追加した。

34. 慢性甲状腺炎に於ける機能調節機構

名大第一内科 满間 照典, 西崎 恒男, 長谷川晴彦, 石突 吉持 我々は $\mathrm{T}_{3}$ 抑制試験を用いて慢性甲状腺炎に於ける下垂体甲状腺系の態度を観察し, 慢性甲状腺炎の進展 に関して臨床的立場から考察を行なつた。臨床所見及び検査結果から診断した慢性甲状腺炎 114例並びに抗 甲状腺抗体陽性の未治療甲状腺機能充進症28例を対象とした。 $\mathrm{T}_{3}$ 抑制詿験は $\mathrm{T}_{3} 1$ 日 $100 \gamma 2$ 週間投与を 行ない 6 日目，13日目の $\mathrm{T}_{3}$ 抑制率を算出した。慢性甲状腺炎に於ける $\mathrm{I}^{131}$ 摂取率， RSU は年令の進む につれて低下する傾向が認められたが，甲状腺機能六進症では加令による低下傾向が認められず慢性甲状腺 炎では加令によつて TSH 依存性に差のある事が認められた。慢性甲状腺炎に於ける $\mathrm{T}_{3}$ 抑制率は健常者同

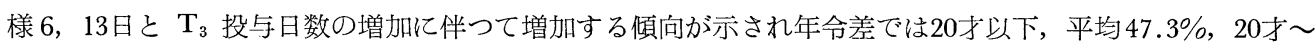
40 才，平均 $60.1 \% ， 41$ 才 60才，平均 $70.6 \%$ 年令が進む従つて増加する傾向が琹められたが，甲状腺機 能穴進症同様の低抑制率を示した症例が114例中17例に見られ，殊に6日目より13日目に低抑制率を示した 症例が 6 例に認められた。低抑制率を示した17例中12例は39才以下で若年群に多く見られ LATS は 5 例中 2 例に検出された。かかる事実は慢性甲状腺炎と甲状腺機能六進症との病態に類似幽のある事を示唆し慢性 甲状腺炎の進展に下垂体甲状腺系が大きな関連を有する事を示唆したものと考觉られる。

質 問 : 東大吉利内科 尾形 悦郎 (1)時間的経過従つての甲状腺病態の変化を論じておられるが，同 一症例てついて，時間的にてのような経過を追跡しましたか（2) RSU が40\%以上のものまで入ってます が，てのような症例は hyperthyroid state ではなかつたのですか (3) $\mathrm{T}_{3}$ suppression 陰性の症例から TSH 分泌動態の異常を論じておられるが，乙のような症例の中には growes'disease, multinoculargoiter が混じ ている可能性はないか，慢性甲状腺炎とてれら疾患とが合併してもよいと思う。すると，てのような data から TSH 分泌動態を論ずるのは無理のように思えるが.

応 答: 名大第一内科 満間 照典 臨床所見臨床症状にて診断を行なつた。 RSU の少し高いものでも 中毒症状の所見は全く見られなかつた。

質 問: 京大第一内科 永田 格 満性甲炎に suppression test でそして LATS がみられたのは興味 深い, 診断の根拠は何か.

応 答: 名大第一内科 満間 照興 臨床症状臨床所見, 抗甲状腺抗体, 生検学にて慢性甲状腺炎である.

応 答：名大第一内科 後藤 宗治 Adjuvant のみによる検討はしていない， 
質 問: 阪大第一内科 宮井 潔 我々も, 眼球突出, 軽度の甲状腺腫を有し, $\mathrm{T}_{3}$ suppression test で抑制されず，LATS を認めるなど一見バセドウ病に類似するが一方血中に抗甲状腺自己抗体を認め, 組 織学的にリンパ球沪胞の形成がみられるなど慢性甲状腺炎像を示し euthyroid である症例を経験しており， おそらく Liddle らのいう Graves' disease without hyperthyroidism のカテゴリーに属する疾患群であ ろうと思われる。

35. 胗原病及びその類縁疾患時の甲状腺生検所見よりみた抗甲状腺抗体の意義

慶大三辺内科 土屋 雅春, 亀谷麒与隆, 島袋 嘉修, 小林 信正, 高木 桂三
慶大赤倉外科 吉松 博

目的：胗原病及びその類縁疾患で TRG を中心に各種血中抗体を検索しその意義につき検討した．方法・ 結果 : 感作血球凝集反応 (TRG), 間接螢光抗体法にて甲状腺の thyroglobulin, 沪胞上皮, 核, 胸腺上皮, 骨格筋に対する抗体を調べた。 TRG test の特異性については精製 thyroglobulin で吸収試験を行ない確 認した。TRG は40倍以上陽性は重症筋無力症29例中13例 $(44.8 \%)$ ，SLE 33例中13例 (39.3\%), RA 70 例中 25 例 $(35.7 \%)$, RF 15 例中 3 例 $(20 \%)$, その他 “自己免疫疾患” 23 例中 10 例 $(43.4 \%)$ であり, 対照 とした胃炎，胃潰痬（41例中 3 例）及び正常人（65例中 4 例）では7.3\%〜6.1\%に過なかつた. 上記疾患で TRC 陽性例の甲状腺組織をみると 21 例中 20 例に慢性甲状腺炎を認め，び漫性甲状腺炎では散在性に比し抗 体価は高值の傾向を示した。慢性甲状腺炎と膠原病及び類縁疾患の合併について検討すると，慢性甲状腺炎 95例中生検した64例ではび漫性 $25 \%$ ，散在性 $50 \%$ ：非生検例では31例中 $35 \%$ 亿合併症を認めた．生検で確診 した慢性甲状腺炎例のみに限定して各種循環抗体をみると次の如き成績がえられた。 TRC 62例中55例，抗 甲状腺沪胞上皮抗体 22 例中 11 例，抗核抗体22例中 4 例，抗胸腺上皮抗体 22 例中 5 例，抗骨格筋抗体 22 例中 12 例飞陽性, LFT 57例中 22例，BWR 48例中 6 例，coombs 44例中 1 例， LE 細胞52例中 2 例飞陽性. 61例 の Immunoglobulin 值は IgG $1750 \mathrm{mg} / \mathrm{dl}$ 以上 $42.6 \%$ IgA $365 \mathrm{mg} / \mathrm{dl}$ 以上 $24.5 \%, \operatorname{IgM} 137 \mathrm{mg} / \mathrm{dl}$ 以 上 $33.4 \%$ であつた。胸腺所見：胸腺内胚中心の形成はび慢性 11 例中 6 例, 散在性15例中 8 例でありてれらは いずれも重症筋無力症などの合併症を有していた。 Basedow では全例に認めたが合併症はない. Primary mynedema 3 例と合併症のないび漫性甲状腺炎には強い胸腺上皮細胞增生所見がみられた。断案：臨床的 に甲状腺疾患の兆候がなくても，膠原病及びその類縁疾患では TRG 陽性頻度は高く，生検により慢性り ンパ球性甲状腺炎像が証明される。胸腺組織との関係については胸腺内肧中心のみでなく胸腺上皮性細網細 胞増生所見との関係も重視される.

質 問：京大第二内科 日下部恒輔 gonadal dysgenesis の症例或はそれに慢性甲状腺炎, SLE その他 の自己免疫疾患を伴つた症例の経験はないか.

応答：慶大三辺内科 島袋 嘉修 1) すでに70例近くの自己免疫疾患に経胸骨上筥胸腺生検・剔出法 を施行してきたが，gonadal dysgenesis を合併していた症例にはまだ遭遇していない．2）胸腺剔出前後 に各種内分泌機能テストを施行するてとにしており, それらの成績については昨年の本学会で報告したが, 尿中 17-KS などの有意義な変動もみていない.

36. 慢性甲状腺炎患者の静脈内 $\mathrm{Ca}$ 負荷に対する反応性

東大吉利内科 ○江藤 澄哉, 尾形 悦郎, 鈴木 秀郎 東大放射線科石川大二

〔目的】特異的に沪胞細胞に傷害を来たすと考えられる慢性甲状腺炎患者で，負荷 Ca の処理能を検討 する事により，甲状腺沪胞細胞の傷害と傍沪胞細胞の機能状態との関係を明らかにする。〔方法】対象は生 検で確めた慢性甲状腺炎患者23例（粘液水腫 4 例，び慢性11例，散在性 8 例）を $\mathrm{T}_{4} 100 \gamma /$ day 長期投与で euthyroid にしたもの，対照群 5 例で，Ca $15 \mathrm{mg} / \mathrm{kg}$ (Ga gluconate in saline $200 \mathrm{ml}$ ) を一定速度で 4 時 間点滴静注し, 点滴前, 終了時, その後 $4,8,20$ 時間に採血し, 血中, 尿中 $\mathrm{Ca}$ は原子吸光法で, 燐は Fiske-Sabanow 法で測定した. Ca 負荷に対する反応性は点滴終了時，後 4, 8 時間の血中 Ca 值より， 
点滴開始直前の $\mathrm{Ca}$ 值を引いたものを $\mathrm{C}_{1}, \mathrm{C}_{2}, \mathrm{C}_{3}$ とすると $\left(\mathrm{C}_{1}+\mathrm{C}_{2}+\frac{\mathrm{C}_{3}}{2}\right) \times 4$ で表わされ，乙れを $\mathrm{Ca}$ Index とした，尚, 副甲状腺機能障害の疑いある例は成績から除外した。【結果】 Ca 負荷後の血中 Ga 值 の経時的変動をみると, 粘液水腫で $\mathrm{Ca}$ 上昇の度合は最も高く, 点滴終了 8 時間後の回復の度合も最も遅 れ，乙の程度はび慢性, 散在性と順に弱くなる。 Ca-Index（即ち Ca 処理能の低下度を示す）の各群の平 均值は粘液水腫 $37.83 \pm 4.23$, び慢性 $29.0 \pm 7.5$, 散在性 $20.87 \pm 4.12$, 正常対照 $19.68 \pm 5.84$ で, 粘液水腫, ビ慢性は正常群に比し推計学的に有意の差をもつて明かに高值を示し， 3 群の間に於ても推計学的に有意の 差をみとめた。 $\mathrm{T}_{4}$ 長期投与のまま TSH 5 単位連続 2 日刺激後の ${ }^{131}$ I-uptake は残存活性汇胞の大いさを 示すが, これを測定すると散在性, び慢性粘液水腫の順に uptake は低下し, 形態学的傷害の程度と一致し た.したがつて, 慢性甲状腺炎における沪胞細胞の形態学的および機能的障害の程度と Ga 処理能低下の程 度とは平行するものと考えられる〔考案〕慢性甲状腺炎に於ては, 沪胞細胞障害が一次的としても, 二次的 飞傍沪胞細胞の傷害もおてり, その程度は沪胞細胞障害の程度とほほ平行するという可能性が考学られる。 しかし血中, 癌組織中のサイロカルチトニン濃度が高いにも拘らず Ca 処理能低下している甲状腺髄栐癌を 我々は経験しており, 負荷 Ca 処理にはサイロカルチトニン以外の要因の関与も考虑する必要がある.

37. 欠 演

38. 甲状腺血管写の枪討 (続報)

福島医大遠藤外科 遠藤辰一郎, 渡辺 岩雄, 石井 正一, 松浦 清勝, 梅津 昌光 柘植 更一, 伊藤 重男

私共は先に Thyroid angiogram が甲状腺腺内血管形態及び循環動態の面から各種甲状腺腄の病態を解

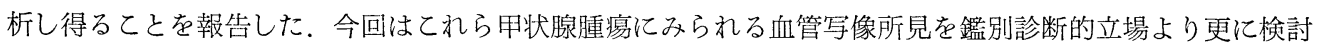
を加えるとともに, Thyroid angiogram そよる腫衫結節の局在部位及び大いさに関し, 診断的限界につい て検討を加えた．まず甲状腺腫痬と血管写像との関連を検討すると，癌腫では血管の中絶，腫瘍血管，腫瘍 像等が高率にみられ，乙れらの像は癌腫診断に対する直接所見と言える。乙のような Malignant pattern は組織学的未分化の所見と共にその発現頻度を増す傾向を示している。一方, 良性良性腺腫では孤状圧排, 緊張伸展が主たる所見である. しかし腺腫でも腫痬血管, 腫瘍像が少数例ではあるが認められ, しかもてれ らの病的血管像は管状及び索状腺腫に認められるが, 腺腫の診断としては前述の孤状圧排, 緊張伸展が意義 ある所見と言觉る. 次に上甲状腺動脈写による䭪痬結節の診断的限界について検討した. 対象とした症例は 良性腺腫例で, Angiogram により認知され，手術により確認された 3 個以内の腫煬結節についてである。 まず, 甲状腺朠痗結節104個の局在性に関し検討すると, 甲状腺側葉中部には 31 個, $29.8 \%$ 亿, 下部は 37 個の $35.5 \%$ あ゙る. これらの所見は腫瘍結節が部に多く発現する傾向を示すとともに, 私共の施行している上 甲状腺動脈写による Angiogram は側葉上部のみならず下部，狭部における腫痬結節の局在も確診し得る ことを示している. 次に血管写で認知出来る結節の大いさについて検討した. 結節は直径 $1 \sim 2 \mathrm{~cm}$ 大のも のが多く，ての種の診断に対しては確実であるが，直径 $1 \mathrm{~cm}$ 以下の結節に対する Angiogram の診断とし ては，我々の認知しているもつとも小な結節は $0.5 \times 0.4 \mathrm{~cm}$ であるが, $0.6 \times 0.6 \mathrm{~cm}$ の結節であれば確診で きると考えている．乙れらの所見は血管形態像と相伴つて Thyroid angiogram の甲状腺腫痬に対する診 断的有意性を示唆するものである。

質問：岩手県立中央病院 栗原 英夫 血管写を行なつて腫痬があると診断し手術を行ない，腫暍を発 見し得なかつた症例はないか。

応 答: 福島医大遠藤外科 渡辺 岩雄 腫場結節の大いさ $2.0 \mathrm{~cm}$ 以上ものにての触知不能な経験なく, $2.0 \mathrm{~cm}$ 以下 $1.1 \mathrm{~cm}$ の結節にては $17 \%$ 前後の結節を術前触知し得なかつた。

応 答：福島医大遠藤外科 石井 正一 1) $2.0 \mathrm{~cm}$ 以下で触診不能結節数はない. 2) Thyroid angiogram にて認知され，手術により結節を確認し得なかつた症例はない.

質問：野口病院 野口 志郎 触診で触知し得なかつたが，血管写で診断し得た症状は，ぞの様な動機 


\section{で血管写を行なつたのか.}

応 答：福島医大遠藤外科 石井 正一 1 側に甲状腺腪瘍を有する症例に対し反対側に施行しましたも のと，主腫瘍を触知した症例の娘腫瘤である。

39. 甲状腺ならびに乳腺腫煬における ${ }^{3} \mathrm{H}$-thymidine autoradiography

$$
\begin{aligned}
\text { 群大藤森外科 岸 成一郎, 藤森 正雄, 泉雄 勝, 㗽場 庄一, 遠藤 敬一 } \\
\text { 東 靖宏, 宮良 当益 }
\end{aligned}
$$

ヒトの甲状腺及び乳腺について，外科手術材料を用いて，Autoradiography を行なつた，甲状腺では， in vivo 及び in vitro の二方法を行ない, 乳腺では in vitro の方法のみを行なつて, 標識細胞率を求め た. 甲状腺の標識細胞率は, 甲状腺々腫は $0 \sim 2 \%$ 範囲に広いバラツキを示したが, 癌では $0.5 〜 2.0 \% の$ 範囲に比較的まとまつていた甲状腺々腫については， microfollicular の方が macrofollicular よりも高い 標識率を示した。乳腺の標識細胞率は, 甲状腺腫瘍の場合の約 10 倍の值を示し, 乳癌の約半数のもの, なら びに Giant fibroadenoma, 及び妊娠初期の Fibroadenoma が高值を示した。乳癌の組織型別の差は見ら れなかつた。乳癌腫瘍の一部の症例には，間質細胞にもかなりの取込みが見られた。

追 加: 信州大丸田外科 ○宮川 信, 飯田 太, 降旗 力男 我々も, 人甲状腺疾患における沪胞 上皮細胞について, in vivo 並びに in vitro flash labeling そより ${ }^{3} \mathrm{H}-$ Thymidine の Autoradiography を行ない，標識率を検討したので追加する，正常甲状腺組織，甲状腺機能六進症および甲状腺炎では，演題 10に述べた理由により generative cell を識別出来ないので，便宜上，generative cell 及び maturative cell の全沪胞上皮細胞に対する標識率を算出した。 その成績は, 対照, 甲状腺機能充進症, 甲状腺炎のいず れにおいても標識率は $0.8 \%$ 以下の低い值を示した，腫瘍では，腺腫は特殊な 4 例を除くと，他はすべて 0.8 \%以下の低い標識率を示すが，乳頭腺癌の標識率は一般に高く，0.8\%から4\%までの間に認められた。ま た in vitro と in vivo labeling の成績について検討すると両者はいずれの疾患においても全く同様の成 績を示すので, in vitro flash labeling 法は実験手段が簡単であり，かつ生体に対する影響が全くないので 推奖すべき方法であると考える.

質 問: 癌研病院 五島 英迪 $1 .{ }^{3} \mathrm{H}$-Thymidine $20 \sim 30 \mu \mathrm{c}$ を in vivo 亿使用するととについて，a) 局所注入量としては多量と思うが, その根拋は，b）手術後, 遺残組織に ${ }^{3} \mathrm{~T}$ が残ら奴証拠はあるか. 2. PNA Labelling は極めて low value である。乙れが Technic fehler ではないととを確かめる為に ${ }^{3} \mathrm{H}$-Cytioline と併せ検討した方が良いと思う。

応答: 群大第二外科 岸 成一郎 (1)大きな腫瘤の中央に局所注射するものであり手術により腫瘤を完

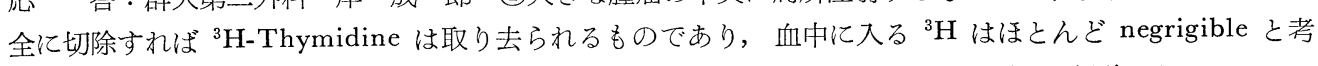
える (2) 露出期間を短期間ですませるように多量に用いた。(3) サイチヂンを使用した経験はない.

40. 甲状腺疾患への超音波検查法の応用，とくに甲状腺機能立進症の ${ }^{131} \mathrm{I}$ 投与量の決定及び その治療経過観察

順天堂大内科 石原 明夫, 内藤 聖二, 北村 和夫 甲状腺機能六進症患者に ${ }^{131} \mathrm{I}$ 投与量を決定する場合には，甲状腺重量測定が最も大切な要因となる，従 来の甲状腺重量測定法は, 甲状腺の発育の仕方が三次元であつて立体的に増大するものを二次元的な投影面 積で解決しょうと試みたとてろに最大の欠点がある。そこで吾々は, 超音波断層法を用い, 甲状腺の厚さを 考慮に入れて甲状腺重量の測定を行なつた。，その結果，シンチグラムの甲状腺表面積からの Allen-Goodwin 法と甲状腺の厚みを考慮に入れた。 B-scope 法との比をとると平均1.39で甲状腺機能九進症例ではその比が 1.41〜1.65となり，表面積から測定した甲状腺重量が実際より大きく計算されている．B-scope 法による甲 状腺重量を考慮に入れた ${ }^{13} \mathrm{I}$ 治療前後の甲状腺面積の変化と甲状腺重量の変化を表に示すと表面積の変化 に比較して甲状腺重量の変化が大きいととが理解出来る. 従つて甲状腺重量（容積）の変化は表面積の変化 より甲状腺の厚さの変化が大きいととを意味する。すで吾々は ${ }^{131} \mathrm{I}$ 治療後の甲状腺機能え進症患者の甲 状腺腫の変化は表面より厚さの変化が大きいととを発表したが今回は更にての事実を確認し得た，以上の方 
法で甲状腺機能六進症患者に ${ }^{131} \mathrm{I}$ 投与量を決定し，治療した129例についての治療成績は 116 例（90\%）が 治㾤例， 10例（7.7\%） が難治例， 3 例 $(2.3 \%)$ が機能低下症であつた。 3 例の機能低下の出現は ${ }^{131} \mathrm{I}$ 計 算量で効果を認めないため 6 ケ月以内に ${ }^{131} \mathrm{I}$ 再投与を行なつたため 発生した。 甲状腺機能亢進症の䛦断及 び治療に超音波検査法はきわめて重要であり， ${ }^{131} \mathrm{I}$ 治療の効果を高め，かつ障害を最小限にするととが出来 る. 超音波検查法を用いて甲状腺重量測定を行ない ${ }^{131} \mathrm{I}$ 治療量を決定して以来の 4 年間の成績を報告した。 質 間：野口病院 野口 志郎 1) 治痖率 $90 \%$ と示していたが，何年間 Follow-up した成績か. 2) 全例 4 年間の follow-up か. 3) 8000rad を規準にしているが, 8000rad は多すぎはしないか.

応 答：順天堂大内科 石原 明夫 現在，甲状腺の沪胞上皮の ${ }^{131} \mathrm{I}$ の感受性が，バセドー氏病，正常 の沪胞上皮に於いて決定されていない，甲状腺 $1 \mathrm{~g}$ 亿つき7,000〜8,000 $\mathrm{rad}$ が甲状腺機能六進症の場合の治 療量を適当と考えている. 今後更に少ない $\mathrm{rad} / \mathrm{g}$ についても検討してみたい.

質 問：伊藤病院 伊藤 国彦 測定した甲状腺重量を実際にはどのようにして確められたか, Allenの 方式では甲状腺腫が大きくなる程，係数が大きくなる傾向がある．

応 答：順天堂大内科 石原 明夫 正常甲状腺及び甲状腺腫，バセドー氏病について症例は少ないが， 剔出甲状腺重量と Allen-Goodwin 法及び B-scope 法とを比較検討したととを既に報告した。正常甲状腺 の場合は Allen-Goodwin 法がかなり適合するがバセドー氏病では，甲状腺肥大が三次元的增大を示すも のを二次元的な表面積から算出している点で Allen-Goodwin 法は，非常に差が出て来る.

質 問：信州大丸田外科 牧内 正夫 甲状腺機能元進症では Allen-Goodwin’ 法と超音波断層法との 間にどの様な相関々係がみられたか.

41. 甲状腺腫瘦の病巣占居部位について

国立栃木病院外科樋口 公明, 堀江 久夫, 麻薙 章吾 甲状腺側葉を，上部，中部，下部に分け，更に狭部，側葉全体に分けて，甲状腺腫瘍の病栄占居部位をみ ると，良性例 327 例（霻腫，腺腫，結節性甲状腺腫を含む）では $85 \%$ が中部を占居し上部は僅少であつた。 それに対し乳頭腺癌例（78例）では，上極，下極を占居する症例が圧倒的に多くみられた．又沪胞腺癌例で は，上，中，下部側葉全体に平均的に占居している，又，組織学的に各部の分布をみると，上部を占居する 腫痬の70\%が悪性例であるが，中部では $85 \%$ \%゙良性例であつた。下部を占居する腫瘤は悪性例がやや増加し， 側葉全体になると約 $50 \%$ が悪性例であつた。

追加：信州大丸田外科 牧内 正夫 最近 5 年間に手術を行ない, 組織診断を明らかくした症例のうち, 多発例， 1 側全葉占居例を除き腫瘤占居部位を検討した。癌，腺腫共に下極に最も多く，次いで癌は上極に， 腺腫では中部に多い，つまり上極占居例は癌の $27.5 \%$, 腺腫の $13.2 \%$ であつて, 癌の方が上極に発見される 率は高い。また狭部は癌, 腺腫共に少ないが，その頻度は癌 $9.2 \%$, 腺腫 $1.4 \%$ で両者間に有意の差をみとめ た。

42. Competitive protein binding analysis による血中 Thyroxine 測定法の検討

札幌医大和田内科 大原 弘通, 林田雅千代, 島田 孝, 和田 武雄

Competitive protein binding analytic method (Tetrasorb Test) を利用した血中 Thyroxine 測定法 について臨床的ならびに基礎的検討を行なつた，対象としては，甲状腺機能光進症38例，甲状腺機能低下症 6 例, 非中毒性甲状腺腫 13 例, 橋本病 7 例わよび䎲 TBG 変化を来たすネフロース症候群 4 例, 肝硬変症 3 例，妊娠13例を選び血中 Thyroxine 量を測定した。測定結果は次の通りであつた。 甲状腺機能正常対 照群 $5.2 \sim 11.8 \mathrm{mcg} / \mathrm{dl}$, 甲状腺機能穴進症 $15.3 \pm 5.8 \mathrm{mcg} / \mathrm{dl}$, 甲状腺機能低下症 $1.63 \pm 1.1 \mathrm{mcg} / \mathrm{dl}$, 非中毒性甲 状腺腫 $6.7 \pm 3.8 \mathrm{mcg} / \mathrm{dl}$, 橋本病 $5.7 \pm 2.6 \mathrm{mcg} / \mathrm{dl}$, ネフロース症候群 $2.8 \pm 0.9 \mathrm{mcg} / \mathrm{dl}$, 肝硬変症 $8.7 \pm 2.4 \mathrm{mcg} / \mathrm{dl}$, 弤娠 $7.0 \pm 2.5 \mathrm{mcg} / \mathrm{dl}$. 各種甲状腺栈㭧について血中 Thyroxine 量と PBI, BMR, T-3 Resin Sponge Uptake Test (T-3 RSU) との関係を検討した. PBI とは41例について検討を加え, 相関係数 $\mathrm{r}=0.85, \mathrm{p}<0.001$ と有意であつた。ささらに BMR は31例 $\mathrm{r}=0.67, \mathrm{p}<0.001, \mathrm{~T}-3 \mathrm{RSU}$ は57例 $\mathrm{r}=0.75, \mathrm{p}<0.001$ と，共に高 い相関を認めた。また Clark 等による Free Thyroxine Index による值と血中 Thyroxine 量とをみると， 
36例の検討では $\mathrm{r}=0.95, \mathrm{p}<0.001$ と極めて高い正の相関を示した。本法に対する Urografin, Telepaque 等ヨード含有造影剤の影響をみたが，測定值には全く影響を与えず，また 4 ケ月から 6 ケ月に至る血清凍結 保存も同様顕著な変化を示さず, 本法の安定性が高いととがうかがわれる，以上により，本法による血中 Thyroxine 量の測定結果は甲状腺機能異常をよく反映し, PBI 等他甲状腺機能検査と高い相関を示した. さらに造影剤，血清保存等によつても影響されない比較的簡便かつ安定な方法で原理的にもすぐれた方法と いえる。

質 問: 京大中央放射線部 森田 隆司 Tetrasorb 值が妊娠の例で正常值〜正常以下の例が殆んぞです が, 妊娠日数は何ケ月の例ですか. 我々の測定值では妊娠ではPBI と同様に高值を示す。しかしFree Thyroxin Index を Tetrasorb 值を用いて算出すると正常域隹入る.

応答：札幌医大和田内科 林田雅千代 1 ）妊娠例は可及的に早期のものを選んでいるが，各月に渉つ ている. 2) Free $\mathrm{T}_{4}$ Index の例には婚娠例は含んでいない.

質 問: 天理病院 稲田 満夫 BEI と $\mathrm{T}_{4}$ 值の相関が悪いのは BEI 測定の均に recovery で補正すれ ばもつとよくなるのではないか.

応答：札幌医大和田内科 林田雅千代 甲状腺機能正常対照群については他疾患併存例は含んでいない. 正常範囲は 26 をとつてある。

43. 欠 演

44. 赤血球蛋白とくに甲状腺ホルモン結合蛋白について

京大第二内科 日下部恒輔, 藤井一男

${ }^{13} \mathrm{I}$ 標識 triiodothyronine ( $\left.{ }^{131} \mathrm{I}-\mathrm{T}_{3}\right)$ 又は thyroxine $\left({ }^{131} \mathrm{I}-\mathrm{T}_{4}\right)$ と incubate した赤血球の膜を採取し, てれを脱脂肪して Sephadex 及び Sepharose によりゲル濾過を行なつた. Sephadex G-100, G-200 及び Sepharose 4B そおける pattern は void volume で elute されるものの他に二つの蛋白成分が分離され, ${ }^{131} \mathrm{I}-\mathrm{T}_{3}$ 及び $\mathrm{T}_{4}$ はそのうち分子量のより小さい方の main component 汇結合している. よつてての蛋白成

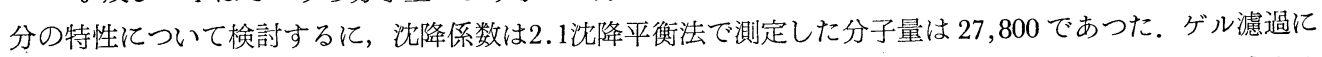
おける pattern, 沈降係数及び分子量より見て，乙てに分離された ${ }^{131} \mathrm{I}^{-} \mathrm{T}_{3}$ 及び $\mathrm{T}_{4}$ を結合する蛋白成分は 膜の所謂構造蛋白質 structural protein である. $\mathrm{T}_{3}, \mathrm{~T}_{4}$ の赤血球への摄取に膜の構造蛋白質が関与するて とより考元, 二, 三の疾患について赤血球の ${ }^{131}{ }^{1}-\mathrm{T}_{3}$ 摂取率を見るに, 発作性夜間血色素尿及び癌では低值 を示す。乙れは，之等疾患に於て赤血球の膜の構造或はその蛋白成分々欠損乃至障害があるととを推測させ るものである。尚, 赤血球, 赤血球膜及びその構造蛋白質と ${ }^{131}-\mathrm{T}_{3},{ }^{131}-\mathrm{T}_{4}$ との結合には cyclic AMP の 影響は見られない. 構造蛋白質は赤血球膜のみならず他の細胞膜及び mitochondria と共通の蛋白の構成単 位である故, 各種の血中抗体を有する或はその存在が推測されている若干の疾患の患者血清とての構造蛋白 質との間に寒天内沈降反応を試みた。闸㟫機能立進症のうちとくに眼球突出のあるものに強い沈降線が見 られ，機能立進症がかなり高度でも眼球突出のないものにはあまり反応が見られなかつた。粘液水腫, 慢性 甲状腺炎に於ては GF 值の高いものでは沈降線が陽性，TRG のみが高く GF(一)のものでは陰性であつ た. 尚, 先天性ホルモン生成異常に基く甲状腺のうち thyralbumin の証明された症例に於て沈降線が認め られた。 又 SLE 等の所謂自己免疫笑患及び癌患者の血清とも種々の程度に沈降線が見られた。

質 問 : 阪大阿部内科 伊藤貫志男 (1) Serume prorein と $\mathrm{T}_{3}$ 及び $\mathrm{T}_{4}$ との affinity の違いは睡知で あるが, 赤血球膜蛋白と $\mathrm{T}_{3}$ 及び $\mathrm{T}_{4}$ との affinity に違いはあるのかどうか.

応 答: 京大第二内科 日下部恒輔 赤血球膜の $\mathrm{T}_{3}, \mathrm{~T}_{4}$ 結合蛋白即ち構造蛋白質は, 血清の結合蛋白 と異り, ${ }^{131} \mathrm{I}-\mathrm{T}_{3}$ との結合の方が ${ }^{131} \mathrm{I}-\mathrm{T}_{4}$ とのそれよりもやや強い様である.

質 問: 虎の閏病院内分泌科 紫芝 良昌 1 ) 赤血球膜のサイロキシン結合蛋白は, 基質で saturated れ得るものか. 特異的な結合物質は, binding site は有限であり，基質で saturate されると考えられてい るので.

応 答: 京大第二内科 日下部恒輔 赤血球膜の $T_{4}$ 及び $T_{4}$ との結合は incubate する ${ }^{131} I-T^{3},{ }^{131}-T^{4}$ 
の量を増すと共に増大はするが，ある限度以上には増加しない様である，但しその限界についての詳細な検 討はまだしていない。

45. 甲状腺ホルモン作用発現に対する末梢組織ホルモン結合蛋白の役割

\section{群大第一内科 山田 隆司, 七条小次郎}

甲状腺切除や抗甲状腺剤により甲状腺機能低下状態を, 又甲状腺ホルモン $\left(\mathrm{T}_{4}\right)$ により甲状腺ホルモン過 剩状態を造り出し, 之等状態の細胞外夜 $\mathrm{T}_{4}$ 結合蛋白及び未梢組織に対する作用をラッテ横隔膜を用い追求 した．組織の $\mathrm{O}_{2}$ 消費を測定し甲状腺ホルモン作用の一指標とした。甲状腺機能㝋進ラッテの筋肉は多量 $\mathrm{T}_{4}$ を摂取するが, 之は血清 $\mathrm{T}_{4}$ の上昇, 筋肉の表面積, 筋肉内 $\mathrm{T}_{4}$ の上昇によるものではない, 筋肉によ る $\mathrm{O}_{2}$ 消費は上昇してわり， $\mathrm{T}_{4}$ 摂取の上昇は筋肉の機能六進状態に関係すると推定される。甲状腺機能低 下状態のラッテの筋肉は少量の $\mathrm{T}_{4}$ を摂取し， $\mathrm{O}_{2}$ 消費が低下していた，以上の事実から甲状腺ホルモン作 用の発現に末梢の $\mathrm{T}_{4}$ 結合蛋白が或る種の役割を演じているものと思われる.

質 問：岡大小坂内科 放射線 Thyroxine を用いて肝疾㭧時の turn over を調べてみると肝硬変で肝 藏のプールが減少し，それに対して肝，血中以外のプールは增大している。しかし BMR は正常であると いう結果を得たが，先生の実験結果からはどのように考学たら良いか．

応 答: 群大第一内科 山田 隆司 私が調べましたのはあくまでも Hyper- 及び Hypothyroid の状態 下における研究で他疾㭧については意見をのべたくない.

46. Thyroxine-Binding Protein の臨床的検討 (第 4 報)

TBP の affinity と Dialyzable $\mathrm{T}_{4}$ の検討

長崎大高岡内科 湯屋寿一郎, 石丸 正彦, 石橋 秀夫, 前田 蓮十

目的：TBP と free thyroxine との関係は, 非常に密接である. 現在まで, TBP の Capacity と Free thyroxine との相関性は検討されているが, 内因性 Thyroxine level での結合状態と, Free thyroxine と の関係をみるのがより適切と考えられる，従つて今回は labeled thyroxine 0.002 0.004 $\mu \mathrm{g} / \mathrm{ml}$ の微量添加 で affinity を求め, Free thyroxine との関係を追求し, 従来の Capacity と比較検討した。測定方法： TBP の affinity 及び Capacity は, 以前に報告した前田の方法に従い, Free thyroxine level は Dialyzable thyroxine (\%) に, Sephadex Chromatography で purified して求めた Total Thyroxine を乗せ て得た值とした. 対象: 正常者 9 例, 甲状腺機能立進症 8 例, 甲状腺機能低下症 8 例. 結果: 正常者の TBG の affinity は $67.8 \pm 6.4 \%$ (Mean $\pm \mathrm{SD}$ ), TBG の Capacity $0.22 \pm 0.05 \mu \mathrm{g} / \mathrm{ml}$ (Mean $\pm \mathrm{SD}$ ), TBPA の

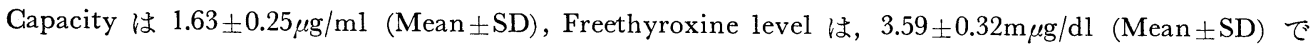
あり, 甲状腺機能進症における TBG の affinity は, 全例低值, TBG の Capacity はほほ全例低值, Freethyroxine level は著明な高值を示した。 甲状腺機能低下症における TBG の affinity は, 全例高値, TBG の Capacity はほぽ全例高值, TBPA の Capacity は正常者群と Overlap し, 一定の傾向がみら れなかつた. Free Thyroxine level は著明な低值を示した。 以上より Free Thyroxine level と TBG の affinity, TBG の capacity 及び TBPA の capacity との相関をみると, affinity では $\gamma=-0.86$, TBG の Capacity では $\gamma=-0.76$, TBPA の Capacity では, $\gamma=-0.64$ であつた. 断案: 以上の結果から, Freethyroxine level そ TBP との関係では, affinity の方が capacity よりも強い逆相関があり, TBG の affinity は Free thyroxine level と最も緊密な関係があると考光られる.

質 問：伊藤 周平 TBP の Binding Capacity と Free thyroxine level との関係はどうか.

質 問：木村 和文 Free $\mathrm{T}_{4}$ は TBG, TBPA の capacity より Affinity 亿高い相関を示すと承りま したが, 微量添加の場合は, 理論的には capacity とAffinity の積に相関するはずであるが, この積に対 する Free $\mathrm{T}_{4}$ との相関係数を求めて居られますか.

質 問: 京大深瀬内科 中川毅 (1) Thyroxine 微量添加による affinity 測定には, 具体的にどれだ けの量を添加されましたか. (2)我々は $0.4 \mu \mathrm{g} / 100 \mathrm{ml}$ の ${ }^{131} \mathrm{I}-\mathrm{T}_{4}$ 添加にて Glycine Acetate Buffer $\mathrm{pH}$ 8.6, そて paper Electrophoresis を行ない測定し, 正常人にて TBG に 75\% TBPA に 15\%, Al そ 10\%の 
值を得た.

応 答: 長崎大高岡内科 湯屋寿一郎 1.TBG の Capacity と TBG affinity（\%)の積と Free 明 に上昇する。 3. Thyroxine level との相関性については，今回検討していない． 2. Hypothyroidismでは affinity は著affinity を求める場合の labeled $\mathrm{T}_{4}$ 添加量は $0.002 \sim 0.004 \mu \mathrm{g} / \mathrm{ml}$ とした。４．Dialyzuble $\mathrm{T}_{4}$ と affinity では, やはり相関性が認められた。相関系数は，算出していない. TBPA の Capacity に関しては, Tris maleate buffer で platen が認められず, glycine maleate buffer で $10 \sim 30 \mu \mathrm{g} / \mathrm{ml}$ で platen に達した。

47. 甲状腺ホルモン結合蛋白分屑の分離に関する検討

金沢大がん研臨床部 ○日置 長夫，斉藤 好正，倉金 丘一

電気泳動法の進歩泮い，甲状腺ホルモン結合蛋白分屑は細分化されつつあるが，いまだ諸家の意見に一一 致しない点がある. Biel \& Z wisler による Polyacrylamide-ultramacro-gel 電気泳動法を用いて, Thyroxine および Triiodothyronine 結合蛋白分屑の分離を実施し次の結果を得，併せて考察を試みた。1）甲 状腺ホルモン結合蛋白分属は, Free $\mathrm{T}_{4}$ 分画 (Band 1) 以外飞, Prealbumin (Band 2). Albumin の Leading edge (Band 3), Albumin zone の中間部 (Band 4), Albumin zone の後端部 (Band 5) およ び Postalbumin 分画 (Band 6) 飞合計 5 個存在するものと推定された. 2) Band 1 と Band 2 は Autoradiography 標本では明確に分離確認することは困難であつた。 3) $\mathrm{T}_{3}$ 添加試料は Autoradiogram で は, Band 3 と Band 4 が分離し難い傾向があつた４）低 Albumin 試料では TBA は Band 4 にのみ 認められた，5) TBG 各分屑中， $\mathrm{T}_{4}$ に対する Affinity は, Band 5 よりも Band 6 が大であると推定さ れた. 6) Cohn Fraction IV-4 中には Band 5, Band 6 を認め, Cohn Fraction IV-4 中には Band 6 の みを認めた。しかし Lipoprotein と甲状腺ホルモンとの結合は人血清中存在しても極めて微弱であろうと とが推定された。

質問：阪大阿部内科 伊藤貴志男 (1)用いられた資料は凍結保存されたものか新鮮血加如何。(2)健常人 の場合にリポ染色をされた事があるか如何か，我々はすでに $\alpha_{1}$-lipoprotein 及び $\beta$-lipoprotein にも Thyroxine が結合する事を報告しているのでその点お聞きしたい.

応 答: 金沢大がん研臨床部 日置 長夫 ®人血清試料は採血後, 直ちに使用しているが, 症例により 凍結保存のものを使用する場合がある。 Lipoprotein 等, 変化し易い分画の検討には特に変性に留意したい. 抗血清を使用する同定法に関しては従来の方法以外の特殊法を併用して今後検討したい. (B) Glycoprotein 注 TBP 分屑の内容のいくつかを占める重要なものと考元る. Lipoproteinもそれに附髄させて考える.

48. 橋本氏病患者血清に於ける甲状腺ホルモンの異常結合

京府医大第二内科 八谷 孝, 塩見 勝彦, 阿部勢津子, 越智 幸男

これは橋本氏病患者のアグロブリン分画に甲状腺ホルモンが異常な結合をした症例報告である，72才女性 で 7 ケ月前より弾性硬の甲状腺腫があつた。 BMR は $6 \%$ ，血清 PBI 6.48\%，24時間甲状腺 $\mathrm{I}^{131}$ 摂取率は $39 \%, \mathrm{~T}_{3}$ レデン摂取率 $10 \% ， \mathrm{~T}_{3}$ 赤血球摄取率は $2 \%$ であつた。抗 $\mathrm{TG}$ 抗体洒は TRC $10^{7}, \mathrm{TA}$ テスト 20であつた，MCF は320倍であつた。甲状腺の組織学的所見は橋本氏用状腺炎であつた。種々のBuffer 即 ち Glycine-acetate, Veronal, Tris-maleate, Phosphate の Buffer で $\mathrm{T}_{4}{ }^{131}, \mathrm{~T}^{131}$ を用いて, 口紙, 及び cellulose-acetate にての電気泳動で患者血清は TBG，アルブミン分画のほかに， ケグロブリン分画に甲状 腺ホルモンが高く結合した。一方てのノグロブリン分画に L-DIT ${ }^{125}$ 及び L-Tyrosine ${ }^{14} \mathrm{C}$ は全く結合しな かつた. TBG，TBPA へのサイロキシンの最大結合は各々18.8，129 r\%であつた。 free $\mathrm{T}_{4}$ は $1.95 \mathrm{~m} \%$ であつた。電気泳動で多量のサイロキシンを添加するとてグロブリン $(3.0 \mathrm{gr} \%)$ へのサイロキシン結合は 74 r\%に達した。泳動の前に人 $\mathrm{TG}$ 亿て患者血清を吸収すれば甲状腺ホルモン $\left(\mathrm{T}_{4}{ }^{131}, \mathrm{~T}_{3}{ }^{131}\right)$ の結合が著 明に減した。２ ケ月間プレドニソロンの投与により ケグロブリン分画への甲状腺ホルモンの結合は減少し， 血清 グロブリンも減少した。 しかし抗 TG 抗体価には大きな変化はなかつた。 てれらの結果からヨード サイロニンのケグロブリンへの結合は TG 抗体価関連があると考光られる。しかしてのようなケグロブ 
リンへの甲状腺ホルモンの異常結合は TG に対する抗体価の高い他の橋本氏病や動物の実験的甲状腺炎で はみられなかつた。

質 問：阪大阿部内科 伊藤貴志男 (1) Premachandra らがすでに橋本病の $\gamma$-globulin hormone の結合を報告しているが，乙の追試で良好な結果は得難いが，乙の例以外に橋本病でかかる結果 を得られた症例はないか. (2)免疫電気泳動をされたか否か.もしされたのならば $\gamma$-globulin のどてに結合 していたか.（この場合の結合は恐らくハプテンの様なものと考えられ，免疫電気泳動の条件と洗涤では恐 らく結合ははずれると考えられるが)

質問：京大第一内科 永田 格 LATS はいかがか。家鬼を人甲，ミクロゾームで免疫すると同 ビ現象がみられ，同時に LATS like shimulator が出現し，後者については私も報告した。Adjuvent の みで処置された事はないか.

応 答: 京府医大第二内科 八谷 孝 1) (1) TRG $10^{4}$ 以上の抗体值を示す橋本病, 甲状腺機能克進者 60 名以上検討したが，現在一例も $\gamma$-globulin $飞 ~ \mathrm{~T}_{4}{ }^{131}, \mathrm{~T}_{3}{ }^{131}$ の結合する症例はない. (2)抗人全血清, 抗人 $\gamma$-gl 血清を用いて Radioimmunoelectrophoresis で $\gamma$-gl 分画 (IgG) に Band を認めた。 2) LATS は 陰性であつた。

質 問：阪大第一内科 網野 信行 $\gamma$-Globulin に $\mathrm{T}_{4}$ が結合する場合の speculation として Hapten 抗体説があるが，乙の様な考方方が正しいとすると，Immunoelectrophoresis で十分 saline で洗浄すると 結合した $\mathrm{T}_{4}$ がはずれる可能性がある．所で先生の所での Immunoelectrophoresis で $\gamma$-G に $\mathrm{T}_{4}$ の結合 がみられたとのことであるがその場合の操作上で洗浄の時間的条件はどの位か.

応答：京府医大第二内科 越智 幸男 1 ）透折は生食中で24時間行なつた。2）サイログロブリン構 造の fine な部分に対する抗体が出来た場合に, この様な gamma globulin 分画に甲状腺ホルモンの異常 結合を示すのではなからうかと推定している.

49. 副腎摘出ラットにおける実験的甲状腺炎成立機作について

名大第一内科 後藤 宗治, 速水 四郎, 水野 路雄, 石突 吉持

自己免疫性甲状腺炎の発症に副婜皮質ホルモンが関与するかどうかを知る目的で，Wistar 系雄うットを 両副腎摘出群と未処置群の 2 群に分け, 同種甲状腺抽出液及び comple Freund's adjuvant を用い 4 〜 週間の長期感作を行なつて実験的甲状腺炎を作成し，副腎の存否が甲状腺炎の成立に及ぼす影響を検討した。 その結果，TRG 抗体価は初回感作後 $4 ， 6 ， 8$ 週間と期間を経るに従つて上昇し，8週間後では全例に $5^{3}$ 〜 $5^{6}$ 倍の高抗体価を示したが，感作期間の各時期における副腎摘出群と未処置群との間に抗体価の差違は認 められなかつた，又，感作期間の各時期における副腎摘出群，未処置群の甲状腺重量と体重との比を求めそ の平均值を算出すると, 初回感作後 4 週間では夫々 $1.13 \times 10^{-4}, 0.77 \times 10^{-4}, 6$ 週間では $1.15 \times 10^{-4}, 0.87$ $\times 10^{-4}, 8$ 週間では $1.76 \times 10^{-4}, 1.25 \times 10^{-4}$ を示し, 感作期間が長期にわたるもの程体重に比して甲状腺重 量は増加し，しかも感作期間の各時期において副腎摘出群では未処置群に比して高值を示す傾向が認められ た. 次に甲状腺の組織所見上炎症像の指標として小円型細胞の浸潤度をとり炎症性組織変化を観察すると， 6 週間, 8 週間と感作期間の長期にわたるもの程組織変化の程度は著明であり, 副腎摘出群は未処置群に比 してょり高度であつた．更に副腎摘出群並に未好置群における沪胞上皮の平均細胞高は夫々初回感作 6 週間 後に $14.7 \mu, 11.3 \mu 8$ 週間後に $11.6 \mu, 10.1 \mu$ を示し, 副腎摘出群は未妈置群に比し明らかな高值を示した. 一方, 非感作ラットについても甲状腺重量並に沪胞上皮の平均細胞高を測定したが, 副腎摘出群と未処置群 との間に差違が認められなかつた，以上の結果より，副腎の存否は自己免疫性甲状腺炎の成立に大きな関与 を有することが示唆された。

50. 甲状腺機能異常症の血中酵素活性（第 4 報）

組織レベルでの酵素上昇機序の検討

新潟大松岡内科 ○泉 正紀, 佐藤 利, 江口 行夫, 原 正雄, 三国 龍彦 佐藤 康行, 松岡 松三 


\section{新潟我信病院宇土沢光徳}

甲状腺機能六進症の血清 GPT, GOT 上昇は肝由来, 甲状腺機能低下症の血清 GPK, LDH, GOT, GPT 上昇は筋由来と報告して来た。 今回はてれらの肝, 筋について, 組織レベルで酻素の上昇機序を検討した。 六進症12例, 低下症12例で肝生検像を見ると, 元進症では実質に肝細胞の巣状壊死, 脂肪変性, 空胞核が認 められ，間質には類洞の搪張，Kupffer 星細胞の増殖が見られた。しかし低下症の変化は軽度であつた。筋 生検像は Hypothyroid Myopathy の1例を除き, 全例正常であつた。乙の肝と筋の組織醉素GPT, GOT, LDH を wet weight あたりで測定したが, 光進症, 低下症共に有意の差はなかつた. 更にての肝と筋の組 織 LDH Isozyme を測定したがやはり有意の変動はなかつた。筋の様気的解糖系の酵素異常が膜透過性に 変化を与えるといわれているが前腕の Ischemic Exercise Test による乳酸測定では充進症, 低下症共に正 常に乳酸産生をみた。血中䤃素 Glearance を家鬼で GPK, LDH, GOT, GPT, Al-p そついて検討した。

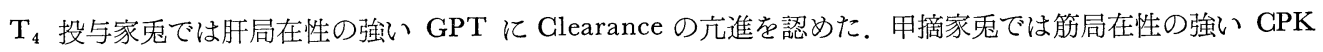
$>$ LDH $>$ GOT の順に Clearance の著明な遅延を認めたが, 筋局在性の少い GPT や AL-P には遅延が なかつた，現在血中非特異䣼素の異化部位は明らかでないが, 低下症では筋局在性の䤉素の異化の遅延が推 定される. 家鬼の肝と筋の組織醳素 GPT, GOT, LDH も wet weight あたりに測定したが $\mathrm{T}_{4}$ 投与家鬼, 甲摘家鬼共に有意の差はなかつた。乙の家鬼の肝と筋の組織 LDH Isozyme を測定すると筋では著変はな かつたが, 肝の $\mathrm{LDH}$ Isozyme $\mathrm{T}_{4}$ 投与家鬼では $\mathrm{L}_{5}$ 即ちM型の娍少, 甲摘家鬼では $\mathrm{L}_{5}$ 即ち $\mathrm{M}$ 型の 增加が認められた。との変化は人肝 LDH Isozyme にはみられず機序は不明であるが, 血中酵素上昇の機 序とは直接関係ないものと思われる。しかし組織環境が LDH Isozyme 組成に与える影響として興味ある 事実と考壳られる。結語. 穴進症の血清 GPT, GOT 上昇は肝組織障害, 低下症の血清 GPK, LDH, GOT, GPT 上昇は筋由来で, 且つ酵素 Glearance の遅延が関与していると考学られる.

51. 甲状腺咨患に於ける脂質代謝に関する研究（第 1 報）

血漿脂酸構成及び内科的治療に伴うその変動

東京医茵大附属霞ケ浦分院内科 須田 彰彦, 大貫 稔

甲状腺ホルモン異常に於いては，脂質代謝異常を来たす事は周知の事実であるが，内科的治療に伴う血獎 脂酸構成の変動を検討したので報告する。今回, 対象とした疾患は, 甲状腺機能充進症及び単純性甲状腺腫 であり, 内科的治療（抗甲状腺剤, 所謂, 脱コレステロール剤, 微量沃度剤他) の前後の経過を追い, てれ を健康人と比較した。総脂質の抽出は, Folch 法を用い. Gloster 等の方法で薄層クロマトグラフィーで, コレステロールエステル, 遊離脂酸, 中性脂肪, 燐脂質に分離し, 更にその各々をメチル化した後, ガスク ロマトグラフィーで脂酸構成を分析し, 面積百分率を半值幅法で計出した. 加療により, 症諸検查值の変化 とほぼ併行して, 各脂質の脂酸構成に興味ある変動を認めたので報告する.

52. 西急性甲状腺炎の統計的観察

岩手県立中央病院甲状腺クリニック 栗原 英夫

過去 3 年間に28例の亜急性甲状腺炎を取扱つた。同期間に当科を訪れた甲状腺咨患々者は 589 例で，その $4.8 \%$ に相当する．乙の頻度は諸家の報告より高いが，乙れは当科が院内各科の甲状腺に関する患者をすべ て取扱っているためと思われる. 発病の季節についてみると, 夏季に多い. 前歴として, 発病前に感冒, 咽 喉頭炎, 扁桃腺炎などに罹患しているものの多い点からみて, virus による感染が疑われた。臨床像として 興味ある点は甲状腺腫が経過を追つて変形し, 有痛性の硬結が腺内を移動するてとであつた。 甲状腺両葉が ほぼ対称的に腫張していたのは 9 例のみで，発病より治瘳までの経過をるると有痛性の硬結は半数以上に移 動するのが認められた，治療は副腎皮質ホルモン投与が 7 例，副腎皮質ホルモンとアスピリンなどの消炎剤 を併用したものが 7 例, 消炎剂のみが10例であつた。急激な症状は投楽により容易に control し得たが, 甲状腺腫の消失には平均 48 日を要した。

追 加：東京医大内科 平嶺 辰郎 当教室で経験した亜急性甲状腺炎患者64例てついて統計的観察を行 なつた成績では, 過去 8 年間の年度別頻度は特に一定の傾向は認められない. 年令別分布では $30 才$ 台が最も 
多く26例， $40.6 \%$ ，次いで40才台 24 例，37.5\%，両者を合わせて $78.1 \%$ と中年女性に多い傾向を示す. 月別 発生例数では 6 月に最も多く，次に 8 月であり，てれを季節的にまとめると，春 20 例，31.3\%，夏 25 例， $39.0 \%$ 最も多く, 秋 $10.9 \%$ ，冬 $18.8 \%$ となり，春から夏にかけて全体の $70.3 \%$ 発生をみている.

質 問: 阪大第一内科 橋本 琢磨 亜急性甲状腺炎の中で他の甲状腺炎を合併していた症例はなかつた か. 小生も覀急性甲状腺炎の様な症状を持つた㭧者がいたが経過を見ていたがシンチグラムで coldnodule あり Opeしたとてろ Papillaryadenocarcinoma with thyroiditis という結果を得た。てれなど炎症の方 ばかり気を奮われていたら carci を見落したかもしれないと反省していますので

質 問：東北大葛西外科 的場 直矢 (1)未分化癌の極く初期に，境界不鮮明な，小さな疼痛ある，硬結 をふれ，血沈が促進していた症例を，覀急性甲状腺炎と詋診した例を経験した。亜急性甲状腺炎の診断時注 意しなければならないと反省している。(2)亜急性甲状腺炎に稀に 1 年近く延再燃を示した例を経験したが， ぞなたか御経験あればお教え頂きたい。

53. 亜急性甲状腺炎の初診時血液所見の検討

東京医大内科 梅原 千治, 大塚 舜一, 手塚 正志, 平嶺 辰郎, 瀬戸山 璋 田辺博, 村田

亜急性甲状腺炎患者64例につき，初診時の末梢血液所見と，諸種甲状腺機能検查につき検討した。患者は 女子 62 例，男子 2 例で年令は 30 ５0才台が全体の約 80\%である. 赤血球数は，350万以下を示したものは全 体の約20\%であつた．発病より初診迄の期間と赤血球との相関では, 発病 1 週間以内のものには貧血は見ら れず，10日以上経過したものに貧血が出現する傾向があつた．血色素量70\%以下のものは，全体の約 $28 \%$ で， 貧血のあるもののうち, 正色素性は11例, 高色素性は 3 例, 低色素性 7 例で, 治療により回復している. 貧 血を年令及び諸種甲状腺機能検查との間には相関は無い. 白血球数では, 全体の約 $50 \%$ 亿 9000 以上の白血球 増多を認め, 約 $10 \%$ \% 15000 以上であつた。発病より初診時迄の期間と, 白血球数との相関では, 発病 1 週 間以内のものは殆んぞ 9000 以上の白血球增多を示し, それ以後は低下の傾向がある. BMR が正常範囲のも のは，白血球増多は殆んぞみられなかつたが，他の甲状腺機能検査と白血球数の間には注目すべき関係は無 かつた．血小板数では，約6\%に10万以下の減少がみられたが，約 $19 \%$ 万，かえつて 30 万以上の増多がみ られた．網状赤血球は全体の約20\%に軽度の増加がみられた，血球百分比では，全体の約 $88 \%$ 好好中球 $60 \%$ 以上の増多を示した。リンパ球は，約68\%に減少がみられ，好酸球では，全体の約 $61 \%$ に減少がみられた。 質 問：熊大第三内科 中川 昌永 52 番では，亜急性甲状腺腫の消失までの時間はかなり早く 48 日とい うことであつたが， ${ }^{131}$ I-uptake の正常化までのデータをお持ちでしたらお教え願いたい．と申すのは甲状 腺腫が消失し，その他の臨床検査成績が正常化したにもかかわらず， ${ }^{131} \mathrm{I}$-uptake のみ長期間非常な低值を 示し，その治療の判定に困惑をした経験を有するからである。

応答：東京医大内科 大塚 舜一 $I^{131}$-uptake は治療前と大体治祲したと思われる 30〜40日後にのみ 施行しているので治療開始後何月頃より正常值に回復するかは不明である。なほ 30 ４0日後には大体正常又 は高値を示していた.

質問：岩手県立中央病院 栗原 英夫 (1)亚急性甲状腺炎と急性甲状腺炎との経別診断で白血球数增多 の有無が重要な検査成績であるといわれているが, 私も白色球增多を認めて亜急性甲状腺炎を 3 例経験して いる．西急性甲状腺炎の場合の白血球増多は，本疾患によるものなのか，それとも合併する他の疾患による ものなのか御教授願いたい. (2)亜急性甲状腺炎と橋本氏病を併発しているものか知れないと思われる組織像 を示した 1 例を経験している。

54. 肝疾患時における放射性サイロキシンの動態についての検討

岡大小坂内科 湯本 泰弘, ○難波 経雄 熊大長島内科 中川 昌壮

放射性 Thyroxine を静注後, 血中消失曲線を求め, 肝放射能体外計測を経時的に行ない, Cavalieri の 方法に準じて，血清と肝臓の 2 compartment system を考え，Kinetic analysis を行なつた。対象は甲状 
腺機能充進水 5 例, 同低下症 1 例, 肝硬変症 9 例, 慢性肝炎 11 例及び健康人 5 例である. Hepatic $T_{4}$ distribution volume $(\mathrm{H})$ は, 正常 $3.00 \pm 0.67 l$, 肝硬変症 $0.90 \pm 0.61 l$, 慢性肝炎 $1.08 \pm 0.42 l$, 甲状腺機能元 進症 $3.02 \pm 0.91 l$. 肝㶓より外へ向う Rate constant は, それぞれ, $0.0104 \pm 0.0012 \mathrm{~min}^{-1}, 0.0177 \pm 0.0067$

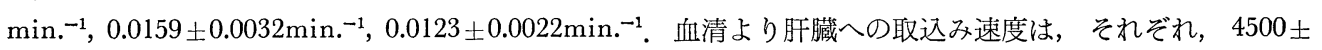

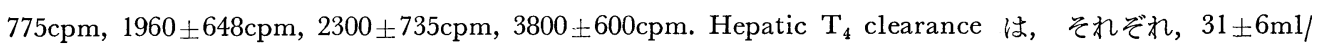
$\min ., 14 \pm 8 \mathrm{ml} / \mathrm{min} ., 16 \pm 4 \mathrm{ml} / \mathrm{min} ., 37 \pm 9 \mathrm{ml} / \mathrm{min}$. であつた. Tracer の尿中排泄率は最初の 6 時間に比 較的大きく，24㭙間值は各種疾患で $11 〜 13 \%$ と殆んぞ差はなかつた，以上より，肝疾患時 $\mathrm{H} の$ 減少及び CH の低下が明らかであるが, 血中 PBI, \% free $\mathrm{T}_{4}$, Triosorb Test, Tetrasorb Test, TBG capacity は 正常と大差はなかつた，又平衡状態における尿中排泄率が殆んど変りない事から甲状腺でのホルモン生成の 抑制は殆んぞないものと考元られる。次に健康人及び肝疾患患者について, 同じ量の放射性 Thyroxine を 静注後, シンチカメラを用い, 経時的に同じ条件で肝及び腎のスキャニングを行なつた。肝疾患では正常に 比へ肝像が淡かつた。腎像は正常では殆んぞ見えないが, 肝疾患では10〜15分より濃く出, その程度は肝硬 変症において強かつた。肝疾患では Thyroxine が腎臟へかなり集まつていくと考えられる. 次いで 3 compartment system を設定して, 血中消失曲線を 3 つの指数函数の和として表わし, Digital computer を用 いて, 各プールの動態を連立常微分方程式の解として求めた。第 2 のプールは肝体外計測値とよく適合した. 肝硬変症において, 第 3 のプール（血清及び肝以外の組織）が増大しており，肝計中への $\mathrm{T}_{4}$ の排浛が少な いという結果を得た。 なお，各プールの経時的曲線を Analog computer でも求めた。

55. 甲状腺ホルモンの肝代謝関する研究（第 3 報）

千葉大第一内科 穴沢 輝一, 上野 高次, 小山 千明, 内山 静剛 我々は数年来, 甲状腺ホルモンの代謝系における肝藏の役割に着目し, ラットを用いて実験を行なつてき た。 今回はラットを甲状腺切除群と非切除群に分け, 更に各群につき, 健常肝群, $\mathrm{CGl}_{4}$ による慢性肝障害 群及び急性肝障害群を作成し, 主として, 胆汁及び尿中に排泄される ${ }^{131} \mathrm{I}$ 一サイロキシン誘導体の, 甲状腺 の有無, 及び肝臟の病態による差異を検討した。即ち, 肝正常ラットに ${ }^{131} \mathrm{I}-\mathrm{T}_{4},{ }^{131} \mathrm{I}-\mathrm{T}_{3},{ }^{131} \mathrm{I}-\mathrm{Na}$ を別々に 静注, 又肝障害ラットに ${ }^{131} \mathrm{I}_{-} \mathrm{T}_{4}$ を静注して, 総胆管カニューレによつて, 経時的に胆汁を採取, 別棌取 した尿と共に，薄層クロマトグラフィーを行ない，各スポットの Radioactivity をウエルカウンターで測 定し, 全投与 Radioactivity に対する \% Dosis/ml を算出して比較検討した. 更に各藏器への R.I の分 布状態についても検討を加えた。 以上の実験により次の如き結論を得た。 Radioisotope 又は Radioactivity の藏器分布を検討するに当つては, 各 R.I 成分の態度を考虑に入れなければ, 理解し難い点が多くあり, クロマトグラフィーによる分析が是非共必要である. $\mathrm{T}_{4}$ 静注の場合, 胆汁及び尿中へ排泄される R.I 量 は, 肝の病態に関らず, 甲状腺每しの方が多い, 胆汁に排泄される R.I で最も多いのは無機ヨードであり, 次いで $\mathrm{T}_{4}, \mathrm{~T}_{3}$ の順である. 之に対し尿では常に $\mathrm{T}_{4}$ が最高を示し, 無機ヨードは微量にしか排泄されな い. I-Na を静注した場合は, 胆汁に比べ尿中へ圧倒的多量に排泄される. 又, Conjugate は胆汁では甲状 腺無しの群にのみ，尿ではわずかであるが甲状腺有無両群に認められたが，量は一般にいわれているより少 量であつた，肝障害が高度になるにつれ，胆汁への $\mathrm{T}_{4}$, Conjugate の排泄は減少するが, 無機ヨードは增 加する，之等の事柄は，肝臟における脱ヨード現象は非常に盛んなものであるてと．脱ヨードによつて生じ た無機ヨードは甲状腺に再摂取されるが，そこにおける新たな $\mathrm{T}_{4}, \mathrm{~T}_{3}$ の合成にはかなりの時間を要する 事等を示唆するものである.

質問 : 岡大小坂内科 脱ヨードが microsome で行なわれているとされているが肝障害時 microsome に 障害が及ぶと肝障害時に胆汁中の無機ヨードが増加しているのはどのように考えたらよいか.

応答: 千葉大第一内科 穴沢 輝一 (1)四塩化炭素による肝障害では胆汁中に排泄される無機ヨードは 正常に比べ明らかに多量であり, 肝における脱ヨード現象の存在を明確にしている. 肝のどの部分で行なわ れるかは検討していない. (2) Conjugate の Spot は TLC の場合 free $T_{4}, T_{5}, t$ の Spot とは明らかに分 解される。 
56. 甲状腺機能異常症における血漿レニン活性

新潟大松岡内科 安積 俊則, 奈良 芳則, 佐藤 利, 永峯 康昌, 山田 彬 松网 松三

我々は甲状腺機能立進症（甲㠵症）にわいて，血漿レニン活性（R活性）が高值を呈す事を発表して来た が，今回その機序を解明する手段として，甲元症および甲状腺機能低下症（甲低症）にわけるR活性，尿中 Vanillylmanderic acid 排泄量 (VMA) を測定，比較検討すると共に，家鬼に $l$-Thyroxine $\left(\mathrm{T}_{4}\right)$ を投与 し若干の知見を得たＲ活性は従来通り Bouscher の変法, VMA ほ Studnitz- 佐藤の高压沪紙電気泳動 法で測定しレニン活性は前回通り採血，VMA もそれに準じて採尿，1分間当たりの排泄量で示した．家 鬼は体重 $2 \mathrm{~kg}$ から $3 \mathrm{~kg}$ のものを一定の飭および採尿箱で20〜30日間飼育後実験に供した。成績および結論 : 安静時 $\rightarrow$ 運動時におけるR 活性, VMA は対照10例で $147 \pm 72 \rightarrow 278 \pm 64 \mathrm{ng} / \mathrm{dl}, 2.0 \pm 0.3 \rightarrow 3.1 \pm 0.3 \mathrm{ug} / \mathrm{min}$ を示したが両者の間には相関は認められなかつた。 甲方症10例では $306 \pm 78 \rightarrow 713 \pm 122 \mathrm{ng} / \mathrm{dl} \quad 2.5 \pm 0.4 \rightarrow 3.9$ $\pm 0.5 \mathrm{ug} / \mathrm{min}$ を示し, 対照と比し $\mathrm{R}$ 活性では有意の差 (安静時 $\mathrm{P}<0.01$ 運動時 $\mathrm{P}<0.05$ ) 認め, $\mathrm{R}$ 活性と VMA の間には有意の相関 $(r=0.65 \quad \mathrm{P}<0.005)$ が認められたが R活性と甲状腺機能との相関は認めなか つた。一方甲低症では $158 \pm 36 \rightarrow 249 \pm 142 \mathrm{ng} / \mathrm{d} 1,2.9 \pm 0.3 \rightarrow 4.0 \pm 0.3 \mu \mathrm{g} / \mathrm{min}$ で対照と比しR活性で差を認め ず, VMA で增加の傾向にあつた。次に家兔で $\mathrm{T}_{4}$ を $1 / 100 \mathrm{~N}-\mathrm{NaOH}$ に溶解連日腹腔内に注入した結果 $50 \mu \mathrm{g} / \mathrm{kg} / \mathrm{day}$ 投与群でR活性，VMA は注入前 9 日間平均に比し 5 日後で $151 \% ， 132 \%$ 亿15 日後で $219 \%$ ， $172 \%$ 上昇， $100 \mu \mathrm{g} / \mathrm{kg} / \mathrm{day}$ 投与例ではより著明な増加を得た。 又対照群および $\mathrm{T}_{4} 25 \mu \mathrm{g} / \mathrm{kg} 10$ 日間投与 群で塩酸イソプロテレノールがR活性におよぼす影響を比較した結果， $0.4 \mathrm{ug} / \mathrm{kg} 30$ 分間注入でそれぞれ 164 $\% ， 312 \% の$ 増加， $0.6 \mathrm{ug} / \mathrm{kg}$ では $253 \% ， 366 \%$ と $\mathrm{T}_{4}$ 投与群でより著明な増加をみた．以上の結果から甲立 症におけるR活性高值は Guanethidine 投与がR 活性を抑制する事実と併せ，甲状腺ホルモンによる交感 神経系の機能九進わよび交感神経系に対する感受性の元進が密接に関与しているものと推察された.

\section{FFA 動員に対する下垂体の関与について（第 1 報）}

名大環境医学研 藤井 健策, 松井 信夫, 石原 一郎 我々は犬を用いて各種ホルモン投与による血漿 FFA の変動を内因性副腎皮質及び髄質ホルモン分泌の面 から検討し，副䐌剔除犬での実験では，ての際の副腎の関与は必ずしも一義的であるとは考えられなかつた ので，今回は下垂体剔除犬を用いて insulin による血漿 FFA の二次的上昇及び noradrenalin の一次的 上昇についててれまでと同様の方法で検討した。 insulin 投与により血墏 FFA は10分以内に低下し，その 後一部の例では前值てまで回復した場合もあるが，大部分は低下したまま経過し，二次的上昇を示した例は 全く認められなかつた。血糖は著明な下降を示した。副腎 catecholamine は特に adrenalinの著明な分泌 増加が認められた。副腎 11-OHCS の分泌は全く認められなかつた。 以上の結果より, 副腎 catecholamine は insulin の血漿 FFA 低下作用には拮抗的に作用しているにしても二次的上昇には一義的な役揢を果す ものではなく，下垂体の関与が大であると思われる，noradrenalin による血墏 FFA の上昇は，下垂体剔 除犬においても，正常犬および副腎剔除犬と同様のパターンで認められたが，その程度は低かつた。血糖は 一過性に軽度の上昇を示した。副腎 catecholamine の分泌は種々の程度に認められた。副腎 11-OHCS は やはり変化しなかつた，従つて，catechalamine の FFA 動員に対して下垂体の存在は essential と言われ ているが我々の実験からは否定的である。しかしながら脂肪組織の noradrenalin 亿対する反応性には下垂 体因子が何らかの関与を有するものと考えられる，以上，下垂体剔除犬では noradrenalin 亿対する一次的 な FFA 動員作用も低下しており，また insulin による二次的な FFA 動員作用も低下しているので, FFA 動員に関しては下垂体は重要な役割を果しているものと思われる。

58. 下垂体摘出尿崩症ラットを用いた plasma natriuretic activity の検討

東大小児科 今井 正, 小林 昭夫

《目的》生理的食塩水の負荷による blood volume expansion 亿際して起る $\mathrm{Na}$ 利尿の機序として, 物 理的因子と体液性因子 (natriuretic hormone) の存在が注目されている。 Natriuretic hormone はもっぱ 
ら近位尿細管に作用して，そてでの $\mathrm{Na}$ の再吸収を抑制すると考光られる，ADH の変化のない条件下で は水の排泄の変化が近位尿細管での $\mathrm{Na}$ 再吸収の状態を反映する。われわれは下垂体摘出尿崩症ラットの クリアランス法を用いて plasma natriuretic activity を測定する方法について検討した. 《方法》 Experimental plasma は saline-bicarbonate を負荷したラットにより得た。24時間前に下垂体摘出したラット 飞 Control, plasma, Experimental plasma, Control plasma の順に持続注入を行ない, 夫々の period での尿量 (UV), $\mathrm{Na}$ 排泄 $(\mathrm{UNaV})$, 自由水クリアランス $\left(\mathrm{CH}_{2} \mathrm{O}\right)$ および糸球体沪過率 (GFR) を測定 した。実験は使用した Control plasmaにより 3 群に分けた。すなわち第 I 群, 正常ラット血漿, 第吅群, 尿崩症ラット血漿, 第皿群, 透折したラット血漿である。《結果》第 I 群, 第 II群では $\mathrm{Na}$ 利尿血獎の注入 時に対照と比へ明らかな $\mathrm{UV}, \mathrm{CH}_{2} \mathrm{O}$ ，の増加がみられた。 $\mathrm{UNaV}$ の上昇は第I群のみに諗められた。第亚 群では UV, UNaV, $\mathrm{CH}_{2} \mathrm{O}$ いずれも対照と比べ有意の増加がみられなかつた。 《断案》以上の data はて の方法により plasma natriuretic activity を証明するととはある程度可能であるが，抗利尿ホルモンの混 在が結果に大きな影響を及ぼすととを示すものである. 従つて本法を定量的に用いるためには assay system より完全に抗利尿ホルモンを除くことが必要となる。

質問：東大中尾内科 吉田 尚 先生の测定法で Vasopressin または oxytocin を投与してその Natriuretic 活性を測定した経験があるか.

応 答: 東大小巟科 今井 正 Assay rat の infusion rate が少いので, 尿量も少い level でみて いるから $\mathrm{ADH}$ を Constant に入れると尿量が更に少くなり判定誤差が大きくなると考えられるので ADH の infusion は行なわなかつた。

質 問 : 東京医雬大第二内科 椎貝 達夫 (1) Assay Rat に対する Plasma 注入速度の決定は何を基準 とされたか. (2) Fractional Na Reabsorption で考えた場合, どのような Pattern そなるか. (3) Berliner らの報告＊によると， Saline Infusion によるVolune Expansion では近位尿細管での Na reabsorption 抑制以外に，近位以下の部分での Na reabsorption 抑制が大きな因子とされている. 從つて Saline Infusion Plasma そより近位尿細管への作用を論ずる場合，UNaV GFR 測定では結果が。不正確になると考光 るがどうか. *J.C.I. Vol. 47, p. 1561〜1572

応 答: 東大小览科 今井 正 (1) Infusion の量は Rector らは $20 \mu 1 / \mathrm{min}$ 程度の少量で行なつて おり，私共も $36 \mu \mathrm{l} / \mathrm{min}$ で尒備的に試みてみた。 ての場合たしかに UV の増加, $\mathrm{CH}_{2} \mathrm{O}$ の増加か認められ るが, Rector らが示した程の大きな変化が認められなかつたので, 注入量を $55.6 \mu 1 / \mathrm{min}$ と増してみたわけ である。しかしての場合は Ht の減少が assay rat の全例で認められたように assay rat 自体の Blood volume の増加は避行得なかつた。 (2) Fractional sodium reabsorptian でみても著明な natriuresis は認め られなかつた。(3いわゆる third factor は physical factor と humoral factor 亿分けて考光るととが出 来ると思うが， saline を load した動物での各 tubular segment での Na の抑制効果はての両者の影響を みているわけで, natriuretic hormone の作用だけみているわけではない. natriuretic hormone について も，Rector らにより近位に作用するてとは明らかであるが，それ以外の部位に作用しないかどうかは問題 があるが，少くとも Rector らその他の data を信用する限り，尿中 Na 排泄としては余り増えていないの で distal ではむしろ再吸収が充進していると考えてよい，ててで閭題となるのは saline load のときの natriuresis は主として physical factor がつよいととで, natriuretic hormone がはたして存在するかど うかに関してはまだ決定的ではないように思われる。私共の data をみても，ADH の減少によつても十分 説明され得るので更に検討を要すると思う.

59. 漏斗茎を出生直後に破壊されたラット内分泌腺の発育について

新生ラットにおける下垂体離断の影響

徳大第二解剖 大黒 成夫, 遠藤 章二, 高津 匡雄 出生直後20一24時間の新生ラットを用い，下垂体茎と正中隆起底部を電気的に凝固破壊し，後，動物の成 長と下垂体をはじめとした内分泌腺の機能状態の推移を組織学的に術後20-23日，40-43日及び60-70日の 
三期に分けて検討した，視床下部においては，正中隆起底部の損傷をうけた動物において，弓状核の細胞に 著明な変性像が見られ，下垂体茎が切断された動物では視索上核及び室旁核の細胞に著明な変性像が見られ た. 成長と生殖腺の発育は極めて強度に障害され，甲状腺及び腎上体のいずれも組織学的には，機能低下の 像を示した．かような成長及び内分泌腺における発育と分化の阻害の結果から勘案すると，下垂体及び内分 泌腺の正常な分化と機能維持のためには，下垂体と視床下部との間の健常な下垂体門脈系血管及び神経性の 連絡が必要であることが推察される。

質問：慈恵医大第二解剖 石川 博 1）分婏直後の新生児ラットを用いる実験では，親が新生児ラ ットを食殺することが多いが，乙の食殺を防止する方法を御存知でしたらおしえて下さい，2）分娩直後に 漏斗茎を破壊された新生児ラットの parafollicular cell は，どのように変化するか.

応 答: 徳大第二解剖 大黒 成夫 1 . 食殺について：解決法 1 ) 経産の動物を用いる事 2 ) 手のにお いを消す事 2 . 松果体, 胸腺, 膵蔵の検索は今後に残している，3. 甲状腺における傍口ホ細胞は現在検 索していない。乙れには特殊な染色法が必要なのではないか.

質 問：阪大解剖 塩谷弥兵衛 (1)松果体に何らかの変化があつたか. (2)胸腺は如何か.

60. ラット下垂体後葉の超微細構造とくに絶水による変化について

群大内分泌研形態部 黒住 一昌

グルタールアルデヒドと四酸化オスミウムの混合液によつて固定したラット下垂体後葉を電子顕微鏡で観 察した，実験動物は正常，絶水 24 時間および 4 日間の 3 群である。下垂体後葉は神経性要素と間葉性要素か ら成り, 前者はネウロン性要素とグリア性豊素をふくみ, 後者は毛細血管と血管周囲結合組織成分から成る. 後葉の神経線維の大部分は神経分泌線維で, 約 $200 \mathrm{~m} \mu$ の直径を有する多数の神経分泌顆粒によつて充たさ れている。その他少数の非分泌性神経線維も存在する。絶水により動物を脱水状態におくと，神経線維内の 神経分泌顆粒は著明に減少し，個々の分泌顆粒の電子密度も低下して，遂には空胞状となる．神経分泌性線 維の終末部には上記の神経分泌顆粒の他に，直径約 $50 \mathrm{~m} \mu$ の聅虚なシナプス小胞が多数ふくまれている. とのような神経線維の他に $100 \mathrm{~m} \mu$ 大の有芯小胞と $50 \mathrm{~m} \mu$ 大の空虚なシナプス 小胞をふくむ神経終末が少 数ながらみとめられる，後葉のグリア細胞である pituicyte（後葉細胞）は 2 型に分類される。第 1 は大型 の明るい細胞で protoplasmic pituicyte とよび，多数の脂肪滴をふくむ. 第 2 は小型の暗い細胞で reticular pituicyte とよび，まれに脂肪滴を有する。2 個の後葉細胞の接触面には，しばしば nexus（膜癒合） がみられる，細胞表層には毛状被覆を有する pinocytotic vesicle がしばしばみられ，脱水早期に多数出現 する. protoplasmic pituicyte の脂肪滴は脱水期に増加かつ増大する。このととから, 神経分泌物あるいは, その被膜に由来するリポ蛋白が pinocytosis によつて, 神経終末から後葉細胞に移行し, lysosome 酵素に よつて分解され，脂質部分が脂肪滴になるものと推察される．後葉細胞の lysosome には，小さな脂肪滴が しばしばふくまれている，従つて後葉細胞の脂肪滴は後葉ホルモン（神経分泌物）の放出に伴なう老廃物の 蓄積といつてさしつかえないであろう. reticular pituicyteも脱水時には小脂肪滴をふくむ大きな lysosome をもつようになる。

鳟問：慈恵医大第二解剂 吉村不二夫 1 . 神経分泌顆粒の膜が pituicyte の内に侵入して，乙れを材 料として脂肪顆粒が出来るという訳か. 2. 動物によつては pituicyte 内の脂肪顆粒は少いものもあり， ラットは寧ろその多い動物の代表だと思うが，てれについてはどのように考えるか.

応答：群大内分泌研 黒作一昌１。神経分泌顆粒にふくまれる lipoprotein あるいはその限界膜に ふくまれる lipoprotein（後者の可能性が高いが）が, 溶解して soluble となつたものが, pinocytosis に よつて後葉細胞にとりこまれると考えている，2．ラットは最も脂肪滴を多くもつ動物ですが，マウス，モ ルモット，イヌ，サル等にも少量だが存在し，Romeis（1940）はヒトにおける存在を記載している．神経 分泌性線維または終末の内部で, 分泌て伴う lipoprotein の全剰産物をスムースに処理できるかどうかとい う点に動物によつて差があるものと思われ，ラットでは，その処理が不充分なため後葉細胞が分泌の後始末 をするものと考えている. 
質 問: 徳大第二解剖 大黒 成夫 1 . ライソゾーム様構造を含んだ神経線維の意義について御教えて いただきたい，2．Cored Body 含有神経線維と後葉細胞との間にシナップス構造を認めた事があるが， 黒住教授は御覧になつたかどうか.

応 答: 群大内分泌研 黒住一昌 1 。神経分泌性線維においては, 分泌顆粒をふくんだ lysosome を しばしば見るので，正常状態においても分泌顆粒が変性崩壊するてとがあり，てれが lysosome 亿おいて 行なわれると思う。非分泌性線維の lysosome はミトコンドリアその他の細胞小器官の自家崩壊と関係があ ると思う，2．きわめて稀ではあるが，後葉細胞表面往神経線維が接触し，両者の間に Synapseに類似す る形質膜の肥厚がみられるてとがあるが synapse であるとはまだ断定できない.

61. 脳下垂体前葉の中枢性調節に関する電顕的研究

（1） 視床下部の電気刺激による somatotroph（成長ホルモン分泌細胞）および gonadotroph（性腺刺激ホルモン分泌細胞）の変化について

阪大解剖 塩谷弥兵衛, 坂上 正義, 藤本 欣司, 伴 忠康 脳下垂体前葉の機能が中枢神経系によつて調節されているととはよく知られていたが, 近年, 視床下部組 織中から種々の前葉ホルモンに対する releasing factor 或は inhibiting factor が抽出されてから, ての方 面の研究は新たな進展をとげた。われわれは神経系の興奮がごのような機作でホルモンの産生や放出を惹き 起てすかを解明するため，視床下部を刺激して下垂体前葉の変化を電子顕微鏡により追究しているが今回 somatotroph と gonadotroph に関して若干の知見を得たので報告する。【実験方法】体重約 $2.5 \mathrm{~kg}$ のカイ ウサギの視床下部に双極電極を刺入し，60cps，0.5 msec，6V.の短形波を一定の間隔で 5 分，20分， 2 時間 抢よび 4 時間流した後，燐酸緩衝 $4 \%$ glutaraldehyde 溶液により生体固定を施した。摘出した下垂体はさ らに 2 時間同液中に置いた後 $\mathrm{OsO}_{4}$ 溶液で後固定し，Epon に包埋した。〔実験成績】(A) somatotroph ：乙の細胞は最大径 300 350m $\mu$ の電子密度の高い 分泌顆粒を含む. 交感帯（内側視床下野）を刺激する と顆粒の減少, Golgi 装置の著明な発達, 粗面小胞体 (rER) の拡大など, 分泌機能の亢充倠を示す細胞が増 加する，成長ホルモンの放出は insulin 低血糖によつて促進されるが，乙の場合も同様の組織像を示す。 乙れに反し副交感帯 (外側視床下野) の刺激では胞体内に顆粒の立満した細胞が增加し, 細胞内小器管の発 達も悪く, 分泌機能の低下が同われる。(B) gonadotroph：との細胞は最大径 $200 〜 300 \mathrm{~m} \mu$ の perigranular membrane の明らかな分泌顆粒をもつ（FSH-gonadotroph と LH-gonadotroph の区別は不明）. 去勢に より分泌顆粒の消失とともに rER の著しい拡大がおこる，交感带の刺激では Golgi 装置の顕著な発達， rER の掋大，遊離 ribosome の増加など分泌機能の六進を示すものが増加する．乙れに反し副交感带刺激 では胞体内に顆粒の蓄積するものが多く, 分泌機能の低下を示す。〔結語〕成長ホルモンと性腺刺激ホルモ ンの分泌は以上の様な機作により, 交感帯の興奮で促進され, 副资感帯の興奮で抑制される.

質 問：群大内分泌研 黒住 一昌 1 . Multivesicular body の内部に分泌顆粒様の暗調体の入つてい る像をスライドで拝見したが，てれが，機能抑制時にふえることはないか．2. Gonadotroph の分耖顆粒が eruptocrine 様式 (emiocytosis) で出される像が見られるか.

応 答: 阪大解剖 㙁谷弥兵衛 (1) Multivesicular body の出現と視床下部刺激との関係については, まだ確定的な見解を得ておりません。 (2) Gonadotroph のみならず，他の前葉細胞についても， emiocytosis の像は殆んぞ見ておりません。灌流固定の影響もあるのかも知れませんが……

62. 犬下垂体門脈血採取方法の検討

岡大第三内科 大藤 真, 太田 善介, 高原 二郎, 小川 紀雄, 細木 秀美 我々は CRF 及び RF の動的変動を測定する目的で犬の下垂体門脈血の採取を試み成功した，又， Pyrogen 投与による負荷を加元，その時の門脈血中の GRF の変動を見る事に成功したので報告する。ま ず, 犬を Urethane 麻醉後, 下顎骨を正中部で切断し軟口蓋を切開, 鼻咽腔粘膜剩離後, Os sphenoidale に穴を開け硬膜に達する。硬膜を切開すれば，下垂体漏斗部が現われる．次に，鋭利な及物で Median eminence の Pars tuberalis 部に横断位に浅い切開を加え，カニューレ状の硝子管を插入し，下垂体門脈 
血を吸引する，次に Pyrogen を静注後，時間毎に門脈血を採取し，Plasma を CRF-AGTH bioassay (in vitro 及び in vivo) を行なつた。 in vitro では rat 下垂体と閂脈血との Incubation medium をてれと は別に Preincubation した rat 副腎に加え, Incubation し，その medium より Silber の方法で corticosteroids を測定し, corticosterone 反応量で GRF 活性を表わした. In vivo bioassay では Dexamethasone 投与 rat の頸動脈より門脈血を注入後, 副腎静脈血を採取し, corticosterone を Silber の方法で測 定した. 結果 : in vitro 及び in vivo bioassay では Pyrogen に対して䦦脈血中の GRF 活性は明らかに 増加が認められた。

質 問：神大 佐古田雅弘 大変野心的な御研究で敬服しています。次の 2 点をお尋ねします，1）以前 の吾々の犬による測頭法で門脈血採血を行なつた場合, 脳春髄液の混入を警戒したが, 先生の方法ではその 可能性はありませんでしたか. 例えば採取門脈血と末梢血のへマトクリットを比較するというような方法は 2) 門脈血の GRF 活性を検定される場合, その GRF 活性が特異的なものであることを検討されたか. 応 答: 岡大第三内科 細木 秀美 周围からの出血及びリコールは吸引排除するにかかわらずある程度 は混入致しますし, 未梢血に較べてへマトクリット值は低いが, 全血量と Plasma 量を測つてあるし, 下垂 体門脈血はすべてての中に入つているので，問題はないと思う。

応 答: 岡大第三内科 高原 二郎 1) 下垂体門脈血中には nonspecific な factor がある事はもちろ ん考えられる. 今後検討する予定です。現在は in vivo, in vitro Bioassay system で ACTH の standard curve が一応書けているし, in vivo, in vitro Biassay 共に peripheral Blood を対照にして一応は nonspecific factor は除外してある.

質 問 : 京大第二内科 加藤 誶 交感帯の刺激により成長ホルモン分泌が促進される機序はどのよう 亿考えておられるか. 追加：われわれは，正常人にわいて交感神経系 $\beta$ 受容体遮断剂 propranolol の点滴 によつて血中成長ホルモンが増加し, 逆に $\alpha$ 受容体遮断剂によつて血中成長の分泌にも交感神経系の関与し ていることを推定している.

応 答: 阪大解剖 塩谷弥兵衛 視床下部内にある releasing factor が, 交感帯の刺激で問脈血中に放出 され, 前葉に流入して, 前葉細胞の分泌活動をたかめるものと思う。

63. 我々の尿中 $\mathrm{ADH}$ 測定法

弘前大泌尿器科 舟生 富寿, 新谷 洋三, 大和 健二, 三樹 明教 Czaczkes の生物学的測定法と Noble の尿中抽出法に改良を加え比較的良い結果を得たので報告した. 生物学的測定法においては，測定 $2 \sim 3$ 日前に尿摟を作成した体重180〜200gの Wistar 雄 rats を alcohol 麻醉後固定，測定中は下肢内側部静脈より constant infusion pump で 1.5\% ethanol 含有の溶液で補液 を続けた。注入速度は $0.12 \sim 0.16 \mathrm{ml} / \mathrm{min}$ である。検体は下肢内側部静脈より 10 秒で注入， 1 回の注入量は $0.1 \sim 0.2 \mathrm{ml}$ とした. 我々の方法では, 測定中充分な麻酔深度が得られ, 注入圧に耐えられ, 下肢内側部で の静注は技術的に容易で $0.1 \sim 0.2 \mathrm{ml}$ の注入量では循環血液量の増加による尿量の動摇も少く, 測定時間も 延長された。抽出法では, Zinc-Ferrocyanide で吸着した ADH を ammoniac alcohol 溶液で溶出, 遠心 分離の操作を 3 回行ない, $40^{\circ} \mathrm{C}$ 減圧乾固, 残渣を蒸留水溶解, 無水 alchhol で精製, $40^{\circ} \mathrm{C}$ 減圧乾固, 残 渣に一定量の $0.03 \%$ 酶酸生理食塩液を加えて溶解して測定に供した。酢酸生理食塩液による溶解は経日に及 んでも安定な状態で測定が出来た。用量反応曲線は, 標準液として Pitressin (Parke, Davis) を用いて, $10 \sim 80 \mu \mathrm{U} / 100 \mathrm{~g}$ の間で直線関係を認めた．回収率は，尿 $100 \mathrm{ml}$ 当て $200 \sim 1000 \mu \mathrm{U}$ のP Pitressin を加えて抽 出, 測定, 用量反応曲線から対応する Pitressin 量を求め blank を差引いて, 平均值 $77.1 \pm 7.8$ (S.E.) と なつた。. 以上我々の尿中 $\mathrm{ADH}$ 測定法と抽出法, 及びとの方法により得られた用量反応曲線と回収率につ いても発表した.

質 問: 東大中尾内科 斉藤 寿一 本法による特㽞性についての検討として, チオグリコール酸ソーダ

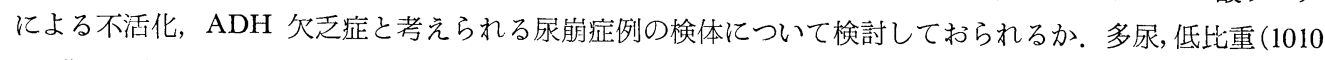
以下）の尿検体を測定することは可能であるか. 
質 問 : 名大無菌所 鵜飼 光雄 先生の方法の最も鋭敏な $\mathrm{ADH}$ の感度の限界とその信頼度について。 質 問：東大中尾内科 村勢 敏郎 生物学的検定法にわいて，サンプル注:入の間かくは何分程度か。 反 応終了の目やすは何か。

応 答: 弘前大泌尿器科 新谷 洋三 1 . 測定可能の最下限值は $5 \mu \mathrm{U} / 0.1 \mathrm{ml}$ だつた。 2 . 尿量の復元 で次の Sampl を注入した。10〜 $30 \mu \mathrm{U}$ であると 30 分後，それ以上の量であると60分以上，復元の時間を要 する.

64. 抗利尿ホルモン $(\mathrm{ADH})$ 分泌調節機構に関する研究 (第 6 報)

東大中尾内科 村勢 敏郎, 斉藤 寿一, 吉田 尚, 中尾 喜久

従来, $\mathrm{ADH}$ 分泌は血漿浸透圧及び血液量の変化によつて調節されているてとが知られている。しかし， これらの因子に加えて，動脈压の変化もその分必に関与している可能性も考えられる. ADH 分泌調節機構 における圧受容体の役割りを明らかにする目的で以下の実験を行なつた，先ず，脾臟摘出犬を用いてクロラ ロース・ウレタン麻酔下に, 各 $0.5 \%$ 体重相当量の血液を股動脈より段階的に潟血し, その際の血行動態の 変化一平均動脈圧，中心静脈圧，心搏出量，中心血液量一を記録し，同時に血中 ADH 濃度を吉田法によ つて測定した。 ての実験とおいて，血中 $\mathrm{ADH}$ 濃度上昇は平均動脈圧の变化と密接な相関関係のあること がみとめられた。乙の結果に基き，次に，血压の低下自体が ADH 分泌に及ぽす効果を観察する目的で以 下の実験を行なつた。即ち，正常大 6 例について，ネンブタール麻醉下にニトロプルシット，ナトリウムを $300 \mu \mathrm{g} / \mathrm{ml}$ の濃度で, 毎分 $0.433 \mathrm{ml}$ の速度で, 肝静脈より持続的に注入し，血圧を前值の，平均 $50 \%$ にま で低下させ，以後経時的に動脈血を採血して $\mathrm{ADH}$ の測定を行なつた。ニトロプルシット，ナトリウム注 入によつて血圧は急激に低下するが，その効果の持続時間は短かい，血中 $\mathrm{ADH}$ 濃度は，注入中止 12 分後 飞前值 $45 \pm 12 \mu \mathrm{U} / \mathrm{ml}$ から $865 \pm 281 \mu \mathrm{U} / \mathrm{ml}$ と著明に上昇した。 てれらの実験から次のことが結論された。

(1)。段階的出血実験では，平均動脈圧の低下が $\mathrm{ADH}$ 分祕を促進させる分泌刺激因子となり得ることが示 唆される. (2)ニトロプルシットナトリウム注入によつて血圧は低下し，それに引き続いて血中 ADH 濃度 の極めて著しい上昇がみとめられた。しかしての際の分歪刺激因子に関しては，ニトロプルシット，ナトリ ウム自体による可能性も否定は出来ず，血圧の低下が直接 $\mathrm{ADH}$ 分泌を促進させたか否かについては，今 後さらに検討する予定である.

質問：岡大第三内科 小川 紀雄 第 1 および第 2 の実験で, ウレタン麻醉，Nembutal 麻酔と麻醉剂 を変更して抢引れるがその理由についてお教え下さい.

応 答: 東大中尾内科 村勢 敏郎 第 2 の実験で, ネンブタール麻酔にかえたのは, 第 1 の実験で, ク ロラロース・ウレタン麻酔では，その手技が繁雑であつたからである。

質 問：東大小坚科 今井 正 (1)ニトロプルシッドナトリウムによる降圧に際して著しい renin release が起ることは，東大上思内科金子博士の report があるわけですが，ての場合の ADH release と renin-angiotensinaldosterone 系との関係をどのようにわ考えか. (2)二トロプルシッドナトリウムを投与し た時血漿滲透圧或は $\mathrm{Na}$ 濃度の変化はどうか.

応 答：東大中尾内科 村勢 敏郎 血中 $\mathrm{ADH}$ 濃度上昇が，直接血圧低下の刺激偟因するとは時下 の段階では即断出来ない．ニトロプルシッドナトリウム自体の可能性も否定出来ないし，血圧低下に基く二 次的変化，例えば御指摘のように Renin-Angiotensin 系等との関係も今後検討しなければならないと考え ている，血圧降下実験では，血墏滲透圧の検討をしていない。ヘマトクリットは変化がなかつた，

65. 尿崩症に扔ける Chlorpropamide の抗利尿作用について

国立東京第二病院内科 佐藤 昭雄，山口 与市

特発性尿崩症 3 例, 腎性尿崩症 1 例, 正常人 8 例飞 Chlorpropomide 1 日 $250 \mathrm{mg} \sim 750 \mathrm{mg}$ 経口投与を 行ない, 投与後 $3 \sim 4$ 日に尿量減少はピークに達し, 投与量増加につれて尿量減少は強められ投与中止後 2 日間有数のものもあつた，尿滲透圧は次第に上昇し，“free” water clearance は sharp 亿減少し 2 例で negative となり正常になつた。 osmolal clearance は有意の変化なく血糖も正常範囲内，腎性尿崩症では抗利 
尿作用認めず，正常人では尿量, 尿滲透圧, “free” water clearance, GFR は不変であつたが Chlorpropamide 投与後の水分負荷では尿量増加はみられず，また特発性尿崩症でも chlorpropamide 投与中水分負 荷を行なつても尿量増加を示さず，留值接作用しているものと思われた，以上の観点からその作用機序と して ADH に類似すべき性質をもつととを示唆する. Chlorothiazide よりは抗利尿作用は強力であり，そ の他の経口糖尿剂である Tolbutamidee, Biganide 剂は抗利尿作用を示さなかつた。

追 加: 虎, 閏病院内分泌科紫芝 良昌, 松崎 辰, 鎮目 和夫 我々も Chlorpropamide 4 例 の真性尿崩症に対して使用して抗利尿作用をみとめ, 尿量, $\mathrm{CH}_{2} \mathrm{O}$ の減少をみた。用量は 1 日 $250 \mathrm{mg} \sim 500$ $\mathrm{mg} 1$ 回又は 2 分割投与でよく，投薬を中止せざるを得ない程の低血糖症状は 1 例に $500 \mathrm{mg}$ を使用したのみ であつた，我々の経験で特に興味深いととは，Thiazide 系利尿剤と併用すると，抗利尿作用が増強される ことで, Thiazide 系利尿剂単独では無効である場合にも, Chlorpropamide を併用すると Chlorpropamide 単独使用の場合よりも効果が強くなる。

質 問: 国立東京第二病院内科 佐藤 昭雄 Chlorpropamide と Chlorothiazide との併用で相乗作用 があるとのととであるがどちらの作用を強めるとお考えか.

応 答: 虎ノ閏病院内分泌科 紫芝 良昌 Chlorpropamide ちらの效果を強めているのかは不明である。ただ，Thiazide が無効であり Chlorpropamide が有效であ る例に併用すると，抗利尿效果か漒まるととから，Thiazide は Chlorpropamide の効果を増強するのでは ないかというととを予想しているが，明瞭な答は出来ない．

追 加：阪大西川内科 川上房男 我々の教室でも特発性尿崩症 2 例飞 Chlorpropamide を使用し抗 利尿効果を認めた。他の Sulfonylurea 剤の Tolbutamide, Acetohexamide の使用では全く抗利尿効果は 認められなかつた. Chlorpropamide と同しく構造的に類似性のある p-(Chlorobenzene-N'-pyrorridinourea)（デアメリンS）の使用により free water clearance の減少を認め抗利尿効果があつた。

66. エーテル麻酔わよび手術侵襲の人血漿 $\mathrm{ADH}$ 濃度におよぼす影響

$$
\begin{aligned}
& \text { 弘前大麻酥科 木村 邦之, 佐藤 一雄, 尾山 力, 工藤 剛, 柴田 進 } \\
& \text { 大山 }
\end{aligned}
$$

エーテル麻醉が $\mathrm{ADH}$ 分泌を増加させるととは従来動物実験で認められてきたが，人に関しての報告は まだない，今回われわれはエーテル麻酔で種々の麻醉深度にわける人血漿 ADH 濃度を Weinstein, Share, 吉田, 沢野らの方法を簡便化した Bioassay により測定した。肝腎機能の正常な手術患者11名を選び，6名 を中等～深麻醉群，5名を浅麻酥群に別け，各群とも麻䣲導入直前，導入後30分， 1 時間， 2 時間，手術開 始後10分の計 5 回血漿 $\mathrm{ADH}$ 濃度を測定した。深麻醉群と浅麻醉群の間では各測定値に有意の差が認めら れなかつたが, 動脈血中エーテル濃度と血漿 ADH 濃度の間には弱い負の相関々係 $(r=-0.51)$ が認め られ，深い麻酔ほど血漿 $\mathrm{ADH}$ 濃度が低い傾向がうかがわれた。11例の平均值で桩酔導入後30分では導入 直前に比べ, 血漿 $\mathrm{ADH}$ 濃度は $16.9 \mu \mathrm{U} / \mathrm{ml}$ 己約 6 倍の增加を示し, 以後次第に 減少して導入後 2 時間で 導入前の值に近くなつた。手術侵襲が加わると再び增加して $34.5 \mu \mathrm{U} / \mathrm{ml}$ となり，導入前の約 12 倍となつた。 麻酔中血清浸透压を ADH 測定と同時に測定したが，各測定值は有意の変化を示さず，エーテル麻酔によ る血漿 $\mathrm{ADH}$ 增加は Osmoreceptor を介したものとは考えられなかつた，尿量及び尿浸透圧の変動は血漿 $\mathrm{ADH}$ 濃度と時間的ずれはあるが，エーテル麻䣲および手術中の尿量減少は $\mathrm{ADH}$ 分治増加が大きな原因 であるととを示唆している。

質 問: 名大無菌研 鵜飼 光雄 血中 $\mathrm{ADH} の$ maximum level に遅れて, 尿量や Free Water clearance の減少がくるとのととだが，血中 $\mathrm{ADH}$ の半減期から考えると，エーテル麻醉後の採血間隔が 30分単位では長すぎる様に思う。

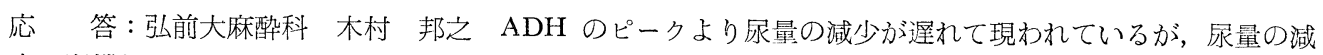
少は腎機能が大きく作用するので, ADH の影響とだけは言光ない。

質 問: 東大中尾内科 村勢 敏郎 エーテル麻酔時の血圧の変動はいかがか. 他の麻酔時の際の ADH 
濃度を検討してありましたらお教え下さい。

応答：弘前大麻酔科 木村 邦之（1麻酔中，手術中の血圧変動はエーテル麻酔では殆んどなかつた。 (2)ペントレン麻酔について ADH を測定しているが，エーテル麻醉ほど上昇しないようである。

67. Oxytocin の生合成, 分泌機序に関する研究

阪大第三内科 矢野 三郎, 熊谷 朗, 山村 雄一

体重 $200 \mathrm{~g}$ 前後の雄ラットに Norepinephrine（Norep.）を皮下注射し，時間的に下垂体後葉 Oxytocin (Oxy.) 量を測定した結果，投与後 $30 〜 60$ 分で Oxy. 量が減少し，3時間後ほぼ正常值に回復する傾向が認 められた。 また Norep. 投与後30分の後葉では releasable Oxy. 量の増加していることも認められた。本 実験にわいては Bioassay で Oxytocic Activity を測定しているので, 以上の変動が, Oxy. 自体の変動で あるととを確認する目的で, 各 Sample の用量一反応曲線および Na-Thioglycollate, Chymotrypsin によ る不活性化についても検討を加えた。つぎにレセルピン（R.）処置動物における Norep.の影響を検討し た. R. ( $4 \mathrm{mg} / \mathrm{kg}$ B.W.) 投与後 24 時間の後葉 Oxy. 量は無処置群に比し変化が認められなかつたけれども, Norep. 投与時の Oxy. 量の減少は無処置群に比し軽度であり, かつ反応が時間的にも遅延しているてとが 認められた．24時間 fasting にした動物では血墏中 FFA が増加し，ての反応はR. 投与によつて抑制され たが，後葉 Oxy. 量は fasting で減少，R. 投与動物では fasting による減少が認められなかつた。この事 実は内因性カテコールアミンの変動も Norep. 投与と同様, Oxy. 分泌関与しているてとを示唆する.つ ぎに Cycloheximide (CH) 投与動物についても同様の実験を行なつたが， GH 投与初期に後葉 Oxy. 量 が軽度減少する傾向が認められたので， $\mathrm{GH}$ 投与 $3 \sim 4$ 時間後の動物を使用した. その結果， $\mathrm{CH}$ 投与動物 (1〜2mg/kg, B.W.) では Norep. 投与による Oxy. 量の減少は全く認められなかつた。 なお，Norep.の昇 压作用は認められたのに反し，Epinephrine の FFA，血糖の上昇作用は抑制されていた。すするわち, Norep. による Oxy. 分必促進作用は昇压による二次的影響よりも，むしろ中枢への直接作用あるいは末梢代謝作 用を介するものと考えられる。

68. 人胎盤成長ホルモン様物質及びゴナドトロピンに関する研究

虎の門病院内分泌科, 東大中尾内科 松崎宸, 橋本千恵子, 鎮目 和夫

Friesen の方法に従つて胎盤から DEAE 及び Sephadex G100 そより HPL を抽出した. HPL 単独で は下垂体摘除ラットの重量増加作は不定であつたとしても微々たるものであつた。しかしヒト GH と同時 に HPL を投与すれば, ヒト GH 単独投与の際の体重増加以上飞增加し, 明らかな協同作用が認められた。 HPL fraction にはゴナドトロピン作用は全然認められなかつた。 下垂体摘除ラットからえた旁惪丸脂肪組 織はエピネフリンに対する感受性が低下しており，GH を投与しておけばての感受性は正常に近くなる。 HPL 投与自体には下垂体摘除ラット脂肪組織のエピネフリン感受性増加作用はなかつたが, HPL と同時 にヒト $\mathrm{GH}$ を投与すると, ヒト $\mathrm{GH}$ 単独投与時以上にエピネフリン感受性を増加させた。 即ち脂肪組織に 於ても HPL はヒト GH の効果を増強せしめた。

質問: 京大産婦人科 富永 敏朗 (1) HPL の FFA 動員作用を in vitro で試みられましたか. (2)抗 原構造に関して $\mathrm{HGH}$ との相違について.

応答: 虎の門病院内分泌科松崎 宸 (1)我々はIn vitroでの添加はやつていない. Tuatle, Kopreis (Clin, Res, 1966) がすでにやつている. 彼らによれば大量では HPL 単独で, 少量ではそれ自体では無効 であるが，HGH と同時に与えた時に lipolysis を促進するといつている. 我々は in vivo に下垂体排除亏 ット投与しておいて，脂肪組織の Epinephrine 亿対する反応をみた。 (2)免疫学的にはすでに外国の報告が 多々あり我々はやつていない。(3)是の生理的意義は妊娠末期では HPL 単独で効果をもつ為高い傾中往をも つが，妊娠早期では HGH との共同作用が重視され，妊娠末期でも単独以上の強力な効果が望める。両者 の lipolytic な作用は血中 FFA 動員を昂める。FFA は胎盤を通過しないが, 母体内で glucose specying に働き, 胎児に glucose 供給を昂めつつ意義を有するし, 母体での anololic anticatabolic 亿働くととは アミノ酸の胎児への供給に意義あるものと考元る. (4) HPL と HGH はアミノ酸組織, 分子量に於て非常 
に近似している。

応答: 神大産婦人科 村田 孝美 in vitro での FFA の動員作用は HPL-B で認められたが HPL-C では $2 \mathrm{mg}$ の大量投与で認められたが HPL-A では認められなかつた。

追 加：神大産婦人科 村田 孝美 私達は HPLの FFA 及び血糖の動員使用をみた. HPL-B, G で は明らかに FFA 動員作用はあるが HPL-A ではこの様な作用はない。更に血糖をみると FFA との同様 の傾向がみられる。 又 in vitro での glucose uptake をみると HPL-B 2mg で glucose uptake の増加 がみられた．更腫晹性絨毛由来 HPL の FFA 動員作用は正常胎盤由来 HPL に近い傾向を示した. 次に HPL の Plasma Lipoprotein lipase, epididymal LPL 及び epididymal HSL をみると夫々 lipase 活性 は増加しているが，両 HPL は lipase 活性に対する作用が若一異つている様である.

69. 人胎児に於ける成長ホルモンの研究

$\begin{array}{lll}\text { 虎の門病院内分泌科 } & \text { 松崎 } & \text { 宸, 鎮目 和夫 } \\ \text { 東大中尾内科 } & \text { 入汇 奏 } & \end{array}$

妊娠中絶時にえられた胎児に於てその下垂体中の成長ホルモン含量を Radioimmunoassay により測定し た. 胎児は 6〜20W，乙とに 6〜 14W のものが多く総例46例であつた。妊娠第 6 週の胎児では全例 $\mathrm{GH}$ は 証明出来なかつたが，第 7 週では 7 例中 2 例，第 8 週では 8 例中 6 例に GH が証明出来た。第 9 週以後は 例外なく全例に $\mathrm{GH}$ が測定出来た。妊娠 2 ケ月では数 $\mathrm{m} \mu \mathrm{g}$, 第 3 ケ月では $10 \mathrm{~m} \mu \mathrm{g}$ から $100 \mathrm{~m} \mu \mathrm{g}$, 第 4 ケ月では $100 \mathrm{~m} \mu \mathrm{g}$ から $1000 \mathrm{~m} \mu \mathrm{g}$ の GH が証明され，1例の5 ケ月の胎児では $41 \mu \mathrm{g}$ であつた. 下垂体 中 $\mathrm{GH}$ 含量は胎令の増加とともに上昇したが，その上昇は体重発育以上であり妊娠 4 ヶ ケ月で $\mathrm{GH}$ 含 量は飛躍的に増加した，数例で臍帯血中 GH を測定したが，成人未端肥大症に匹敵する高值であつた，以 上の結果は従来考えられて居た以上に胎児 $\mathrm{GH}$ がその成長, 代謝に重要な生理的意義を有するととを示唆す るものと思われる。

70. 血中 $\mathrm{HGH}$ と Insulin の相関に関する臨床的研究

岐阜大第一内科 吉田 健生, 磯部 迪, 野手 信哉, 乾 成美

Packer, 井村らは Arginine 負荷により HGH 分泌が高まることを報告した。われわれは HGH と insulin との関連性を知る目的で糖尿病, 未端肥大症, 神経性食思不振症, 健常者に同負荷を行ない HGH, insulin, NEFA，血糖を同時に測定した。（1）HGH：健常者群では若年者の方が老人者より反応は大であ つた．神経性食思不振症は健常者と類似した反応を示した，糖尿病群は健常者群より反応は小であつた（2) insulin：健常者，末端肥大症，神経性食思不振症では30分後に上昇傾向を示した。若年型糖㽷病ではHGH 反応はあつたが insulin 反応のみられない例があつた。（3）NEFA：健常者，成人型糖㽷病では30分で減少 する傾向を認めたがその程度は健常者の方が大であつた，若年型糖尿病では上昇傾向がみられた（4)血糖： 健常者, 糖尿病, 未端肥大症では30〜60分で最高になり120分で前值に回復する傾向が認められたが神経性 食思不振症では一定の傾向がなかつた。

質 問: 東大中尾内科 入江 実 TBGH の副作用はどうか. NEFA の変化はどうか.

応 答：肢大第一内科 野手 信哉 TBGH を一定期間投与した 3 例中 1 例に副作用か溌現したてとか ら消化不充分なものがあつたのではないかと思つている，従つて，その作用，たとえば NEFA に対する作 用には GH activity 以外の因子が介在している可能性を否定するものではない. 菊谷らと協力して今後工 夫と例数を重ねて検討を加えたい.

応答：岐大 磯部 迪 (1) NEFA については 3 時間迄測定しているものもあるが，TBGH $30 \mathrm{mg}$ および40mg筋注の場合にはなお上昇する傾向にあつた。

71. 血中成長ホルモン動態に関する研究（第 4 報）

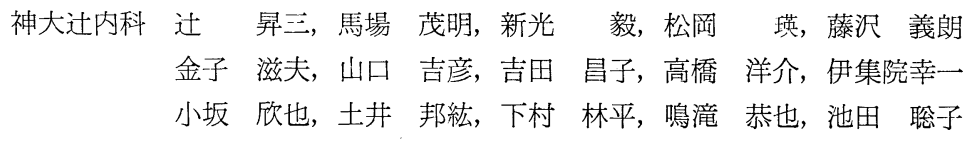




\section{新海 隆子}

我々は免疫二抗体法を用いて下垂体成長ホルモン $(\mathrm{HGH})$ を測定し，その動態を観察して来たが，今回 は諸疾患に於けるインスリン静注負荷, 合成 ACTH 負荷に対する HGH の反応に就て報告した. (1)イン スリン静注, @間脳下垂体疾患: Chromophobe adenoma 3 例では術前, 術後共に反応は低下して居り, Craniopharyngioma 4 例，尿崩症 6 例では一定の傾向が無かつた。糖尿病：腎血管障害を合併するもの では反応に低下の傾向が見られ，網膜血管障害と腎血管障害を同時に合併するものでは明らか々反応が低下 して居た，(肥満症：糖尿病, 非糖尿病で，いづれも反応が低下して居たが, 境界型糖㽷病では遅延反応を示 した. (2) $\beta^{1-24} \mathrm{ACTH}$ 負荷, (a)非内分泌疾患 8 例中 6 例に反応を認めたが，ピークに至る時間は一定しなか つた，又，インスリン静注に反応しなかつたコルチコステロイド治療中の 5 例の内 4 例にも反応を見た．(b) 肥満度 $+30 \%$ 以上の肥満症では反応が無かつた，又，境界型糖尿病 1 例では前夜デキサメサゾンにて Supression を行なつたが，ACTH 負荷後30分にて著明に HGH の上昇を見た。 (C)垂体性侏儒 3 例では反応 が無く, Acromegaly 3 例では異常反応を見た。 以上の成績より, 間脳下垂体疾患では HGH 分泌が低下 して居る事が多く，其他の疾患，殊に婜障害を合併せる糖尿病や肥満症にも低下傾向が見られ，ただ境界型 糖尿病にあつては遅延反応を見る事, 又, 負荷試験の種類に依つては HGH 分泌機序に差のある事を知つ た.

質 問：京大第一内科 井村 裕夫 肥満者はあらゆる分泌刺激に対して HGH の反応が不良であるて とを私どもも経験しているが，先生の症例で borderline diabetic のもののみ比較的よく反忘しているのを， どのようにお考えか.

応答: 神大辻内科 松岡 瑛一般に肥満では, 膵インスリン (IRI) は高いとされているが, 我々 の成績では borderline diabetes の肥満の場合, 明らかに膵内分泌機能低下の傾向が認められており,ての 点からして肥満型 borderline diabetes の場合には内分泌異常状態にあるのではないかと考えられる。

質問：佐々木英夫 尿崩症で HGH の resting level の高い症例につき次の二点につき御教え下さい. 1) 負荷試験をやつておられるかどうか.２）ほかの下垂体機能はどうか.

応 答: 神大辻内科 松岡 瑛 尿崩症の患者について HGH 以外の他の下垂体機能を測定しており ませんのでわかりません.

質 問: 京大第二内科 加藤 讓 網膜出血を来した症例の $\mathrm{HGH}$ 以外の下垂体機能はいかがでした か.

応答: 神大辻内科 高橋 洋介 網膜病変を合併する糖尿病の成長ホルモン以外の下垂体機能に就ては 特に検索して居ない.

質 問 : 阪大第一内科 岡田 義昭 ACTH による HGH 上昇反応の機構についてお教え下さい.

72. 健康者における血清成長ホルモン值

慶大浅野内科 高林 洋一, 鈴木 裕也, 中島 倫子, 蘇原 博史, ○厚治 秀行 片岡 邦三，松木 駿，浅野誠一

人血清成長ホルモン（以下 HGH と略す）の正常レベルを知る目的で, 多数例の正常体重健康者につき 早期空腹時およびィンスリン負荷時の動態を観察した。対象は20〜30才の男子25例，女子28例計53例で，前 夜より12時間の絶食後来院せしめ，30分安静の後採血して早期空腹時検体とし，ただちに $0.1 \mathrm{u} / \mathrm{kg}$ 正規イ ンスリンを静注. 以後 $15 ， 30 ， 45 ， 60 ， 120 ， 180$ 分の血糖および $\mathrm{HGH}$ を測定した。 な㧍，男女それぞれ 5 例は同時に血清 NEFA の動態についても観察した。血糖は男女とも30分で最低值をとり, 前值に比し50 \%の下降率を示す. 男女の血糖値に有意差は認められなかつた。 HGH の平均值は男子, 前 $3.8 \pm 1.1,15$ 分 $5.6 \pm 1.4,30$ 分 $23.7 \pm 4.3 ， 45$ 分 $58.4 \pm 6.0 ， 60$ 分 $66.6 \pm 5.6,120$ 分 $40.7 \pm 5.9 ， 180$ 分 $10.0 \pm 1.6 \mathrm{~m} \mu \mathrm{g} / \mathrm{ml}$. 女子, 前 $10.6 \pm 1.3,15$ 分 $6.7 \pm 0.9,30$ 分 $15.5 \pm 2.0,45$ 分 $35.2 \pm 4.9,60$ 分 $30.0 \pm 4.3,120$ 分 $12.3 \pm 3.5$, 180 分 $2.9 \pm 0.3 \mathrm{~m} \mu \mathrm{g} / \mathrm{ml}$ であつた. 即ち, 早期空腹時の $\mathrm{HGH}$ 值は女子が男子に比し有意に高いが, インス リン負荷後の $\mathrm{HGH}$ 反応については男子が女子に比し増強し，45分以後の毎測定時，推計学的に有意である. 
ての成績は，採血の条件が男女について同様であるので，HGH の男女差を示唆する所見であり，今後とれ に関与する因子につき検討の予定である。血糖の低下と HGH の上昇の間には，男女ともその絶対值およ び面積比について相関々係を認めなかつた。 NEFA は男子ともインスリン負荷後60分より著しい上昇がみ られた。なお，網膜出血を反復する糖尿病女子の 1 例では，インスリン負荷により血糖を充分低下せしめて も $\mathrm{HGH}$ 反応はほとんどみられず，現在症例を增して検討中である．

追 加：京大第二内科 井村 裕夫 私どももインスリン, アルギニン, インデラール (propranolol) などの負荷試験を行なつてきましたが，運動などの影響のため基礎值が高いもので，しばしば HGH の反 応が不良であるという事実を経験している。一般に HGH は連続した二つの刺激には反応が不良になると 考えますので追加します。

質 問 : 岡大第三内科 小川 紀雄 (1)先の入江先生の御発言にもありましたが, 私達も, 全例とは申せ ませんが，HGH の前值の高い場合にはしばしば反応性の低下傾向をみている。(2)血糖下降值と HGH 反 応の相関をみておられるが，血糖の前值に対する減少率（\%)と HGH との比較をなさつておられれば お教气下さい.

質問：阪大第一内科 岡田 義昭 私達も看護婦を対象とし, 日曜日早期空腹時飞, 看護婦寄宿舎から 外来䛦察場までの歩行後に，採血，血中 $\mathrm{HGH}$ 值を測定しましたが，前值が $10 〜 20 \mathrm{~m} \mu \mathrm{g} / \mathrm{ml}$ と高值を示す ことが多く， 2 時間の安静によつてやつと $5 \mathrm{~m} \mu \mathrm{g} / \mathrm{ml}$ 以下に低下したてとを経験している. 先生の御報告で は, 女子の場合前值が高く，15分值が低下していますてとから，安静が充分ではなかつたのではないかと 思うが，如何か。

応 答: 慶大浅野内科 片岡 邦三 被検者女子は本学看護婦で非勤務の日曜を選び検查を施行したもの であり, 寄宿舎から病院まで約 $100 \mathrm{~m}$ 歩行したに過ぎず，30分の安静時間も守らせているので，運動による 影響は認められないと思う。

質 問: 東大中尾内科 入江 実 (1)女の方が男にくらべてィンスリン低血糖に対する反応がわるいと いうのは女で baseline が高いためではないであらうか. 即ち, baseline が高いというのは pituitary の reserve が少なくなつているため, 空腹時值が高い人ではインスリン刺激による最高值が余り高くないとい う相関々係はないか。

応答：慶大浅野内科 厚治 秀行 空腹時 $\mathrm{HGH}$ と負荷後 $\mathrm{HGH}$ の間には, 特に関係はみとめられず, 空腹時 $\mathrm{HGH}$ 值の高いものが低い反応を示す傾向があるとはいえなかつた。血糖の下降と $\mathrm{HGH}$ 上昇の関 係については，絶対值，下降率わよび下降面積など種々の面から検討を加えたが相関はみとめられなかつた。 反復網膜出血を示す糖尿病患者の 1 例については下垂体機能検査は施行していない.

73. 小览に於ける成長ホルモン分泌能に関する $2 ， 3$ の検討

慶大小児科 加藤 精彦, 興水 隆, 久野 良樹, 岡島 昌子, 高倉 故

我々はダイナボット社製 HGH 抗体を用いた二重抗体法により小児の HGH 測定を行なつて来た。早朝 空腹時值は，乳児及び早春期に多少高めの者が多い順向が窅れた。4才から14才迄の正常小児の Novoactrapid Insulin 0.05u./kg 負荷後の血糖，HGH，11-OHCS, NEFA の反応につき述べたが，うち HGH は 5 人で負荷後 30 分, 4 人で 45 分に peah を有し, 平均值の maximum は 30 分で $17.8 \mathrm{~m} \mu \mathrm{g} / \mathrm{ml}$ 前值よりの 上昇 $15.6 \mathrm{~m} \mu \mathrm{g} / \mathrm{ml}$ であつた。 この data をもとに，侏儒を主訴とし来院した40名に Insulin 負荷試験を行 なつた。 そのうち身長ー16から-2,586迄の者 12 名はいずれも $\mathrm{HGH}$ response は正常であつた，身長 $-2,586$ 以下の者のうち hypothyroidism 2 例を除く26例を Insulin 負荷試験の $\mathrm{HGH}$ 反応の有無により hypopituitary dwarfs 12名 genetic or constitutional dwarfs 14名に大別し下記の結果を得た。(1)前者の 血糖值は負荷後15分で最低となり前值の平均 $25.6 \%$ 迄に下降した。Visk て低血糖の有意性から考元 Novoactrapid Insulin $0.05 \mathrm{u} / \mathrm{kg}$ の使用が最も適当であると考えられる。(2)後者では HGH response は正常よ りむしろ良好であつた。 (3) Metopirone test は特発性下垂体性侏儒10名のうち 7 名が正常， 3 各が borderline であつた。この結果と Insulin 負荷後の 11-OHCS response が正常に比し極めて良好であるととか 
ら，少くとも特発性下垂体性侏儒症では多くのもので ACTH 産生は正常であろうと思われる。(4)前者で Arginine 負荷試験を行なつたもの全例に response は見られなかつた。(5)從来困難とされていた思春期前 小児の特発性下垂体性侏儒症と genetic or constitutional dwarfism の鑑別は, 骨年令と歴年令及び骨, 体重年令と身長年令の比率より臨床的にかなり確実に行ない得るととが明らかとなつた。次に Corticosteroids 及び AGTH 投与の $\mathrm{HGH}$ 分泌能に対する影響について検討したが corticosteroids 隔日投与中の者 では HGH 抑制は見られなかつた。合成 ACTHZ 10〜24時間投与後24時間の HGH 分泌能は著明に抑制 されていた.

質 問: 阪大第一内科 岡田 義昭 私達も昨年 selective HGH deficiency を 3 例報告しましたが，先 生の御報告された本疾患々者の家族歴に何か異常はなかつたか.

応答：慶大小児科 舆水隆 血族結婚はありません。家族あるいは近い親せきにdwarfism の者は なかつた。

74. Tryptic Digests of Bovine Growth Hormone (TBGH) の臨床効果に関する研究

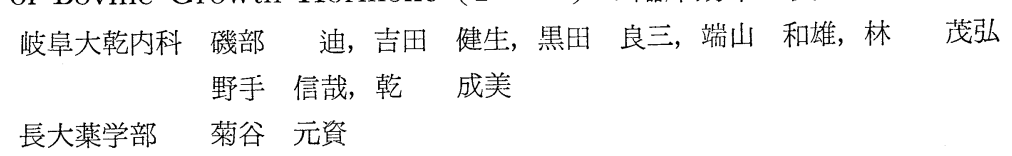

人間に対し hormonal activity を持つ GH は猿のそれと HGH であるといわれている. 最近 Sonenberg, 菊谷らは tryptic digests of bovine growth hormone (TBGH) が人間に対し GH 様活性を持つこ とを報告している. 今回私達は Sonenberg の方法で作られた TBGH を正常者に投与し, その臨床効果を 検索した. 12〜16 時間の絶食の後, 早朝空腹時に TBGH を投与し，その影響を調べたが，I0mgから20 $\mathrm{mg}$ の投与では認むべき効果は見られず，30 $\mathrm{mg}$ から $40 \mathrm{mg}$ の投与例においては NEFA と血糖值の上昇が見 られた。

質 問: 虎の門病院内分泌科 鎮目 和夫 私達も菊谷の方法で作製した TBGH 3 例の Hypopituitarism そ投与し LNE 血中 NEFA と Insulin 感性に対する影響をみたがはつきりした効果は認められま せんでした。なお21日間使用した例があるが抗体産生は調べられたが.

応答: 岐阜大第一内科 磯部 迪今回の実験では抗体については検索していない.

75. 開腹手術による成長ホルモンの変動

$$
\begin{aligned}
\text { 慶大外科 三村 孝, 楢原 德之, 小平 進, 大場 正己, 赤松 隆 } \\
\text { 植松 義和, 植草 実 }
\end{aligned}
$$

外科侵襲に対する成長ホルモン $(\mathrm{HGH})$ の反応を, 血糖, 血漿遊離脂酸 (NEFA) の変動と関連して検 討を加えた。外科侵襲として胃切除手術を選び, 刚分泌疾患を合併しない潰癔20例, 癌12例を対象とした。 年令は22才から69才, 麻酔は全例フロ一七ン吸入麻酔を行なつている. 採血は麻酔開始前, 加刀時, 加刀後 15分，30分， $1 ， 2 ， 4 ， 6$ 時間目に，また第 $1 ， 3 ， 5 ， 7$ 病日の早朝空腹時に肘静脈より行ない, HGH はダイナボットの抗体セットを使用した二重抗体法で，血糖は autoanalyzer. NEFA は Dole 法により測 定した. 術前の $\mathrm{HGH}$ 值は 2 例を除き $5 \mathrm{~m} \mu \mathrm{g} / \mathrm{m} 1$ 以下の值を示した。手術開始直後の血糖値は術中輸液の 種類により異つた変動を示すが，加刀後 6 時間まで徐々に上昇し 術前値の約 2 倍に達する. てれに対して $\mathrm{HGH}$ 值は大部分の症例で加刀後15分で, すでに明らかな増加をみとめ, 30分から120分後に頂值に達し, その後は乎術の続行とは関係なく低下し，4〜6時間でほぼ術前值近くまで回復する. 第 1 病日以降は術前 值を軽度に上下する程度で殆んど変動しない. この $\mathrm{HGH}$ 反応には輸液の種類, 年令, 性別, 肥潇あるい は侵襲の大小などは明らかな影響を及ぼさない，血漿 NEFA の変動も術中輸液の種類によりままた症例に よりかなり舅るが，その上昇の頂值は，常に血獎 HGH の上昇の頂值に遅れてみられるととから，手術侵 襲時の脂肪動員に HGH の果たす役割の大きいてとがうかがえる．副婜皮質ステロイドを長期間使用した I 例では，手術侵襲時の $\mathrm{HGH}$ 值には殆んど変動がみられず， 2 時間後にみられた頂值も $10 \mathrm{~m} \mu \mathrm{g} / \mathrm{ml}$ 亿達 しない。乙の例からは副腎皮質ステロイドの長期使用は $\mathrm{HGH}$ 分泌を抑制するものと考学れれる。 
追 加：弘前大麻醉科 松木 明知 われわれも麻醉及び手術の HGH, FFA，などに及ぼす影響につい て検討した。ペントレン, エーテル麻酔に関して, 導入前, 導入後 15 分, 導入後 30 分, 同 45 分, 手術開始後 10分，30分，60分及び覚醒法の計 8 回 indwelliy catheter 採血した。ペントレン麻䡶では導入前 $1.3 \mathrm{~m} \mu \mathrm{g} /$ $\mathrm{ml}$ 導入後 45 分には $8.7 \mu \mathrm{g} / \mathrm{ml}$ 亿至り, 手術か潤始されると約 30 分で peak を示し, 手術侵襲の長短に拘わ らず，覚醒時にはほぼ正常值に戻つた，glucose，FFA の変動は少なかつた。エーテル麻醉もペントレン麻 酔時とほぼ同じ傾向を示したが, 麻酥自体の影響はペントレンに比して弱く, 手術侵襲の影響についてはペ ントレン群と同じであつた。 Glucose FFA についてもほぼ同じパターンを示した。 現在更に他の麻醉剤に ついて詳しく検討中である。

76. キシリトール静注によるヒト成長ホルモンの上昇

九大第二内科 小串 俊雄, 平田 幸正 キシリトールが正常犬においてインスリンの上昇をもたらすてとをさきに報告した，今回は 15 人の健康正 常者において成長ホルモンの分泌におよぽすキシリトールの効果を検討した. 検者は朝, 絶食後 30 分以上安 静を保たさせたのち, キシリトール0.4 $/ \mathrm{kg}$ を静注した。 15名中 7 名はキシリトール静注後, 成長ホルモン の有意な增加を示したが，残りの 8 人は成成長ホルモンは不変であつた．そてで健康正常者はキシリトール に対して成長ホルモン上昇群と不変群に分けられる。両群の間に, キシリトール静注後の血糖, NEFA イ ンスリンの反応には明らかな差はなかつた。 コントロールとして, 同量のブドウ糖 $(0.4 \mathrm{~g} / \mathrm{kg})$, あるいは生 理的食塩水 $(0.8 \mathrm{ml} / \mathrm{kg})$ を11人の健康正常者に静注した。 ブドウ糖は 5 人, 生理的食塩水は 6 人である. 11名中, 1 名にのみ成長ホルモンの有意な増加を見た.

77. 成長ホルモン分泌系の分泌子備能—Arginine 刺戟と Insulin 低血糖刺戟における差異 札幌鉄道病院, 北大第二内科 上妻 和矩, ○中川 光二, 岡本 政敏, 堀内 淑彦, 真下 啓明 成長ホルモン $(\mathrm{GH})$ 分泌系の分泌予備能の大きさとその制約部位を検討するたすに健康男子に $\mathrm{GH}$ 分 泌刺激を 2 時間の間隔をおいて反覆して加え, 血漿 $\mathrm{GH}$ (二抗体法による radioimmunoassay) の変動を, 血糖 (ferricyanide 法による autoanalyzer による), 血㢡遊離脂肪酸 (FFA; 板谷・宇井の比色法), 一 部では, 血漿 $\alpha$-amino 酸 (Frame らの比色法) の変動とともに観察した. 第 1 刺激として与えた Insulin $(0.12 \mathrm{U} / \mathrm{kg} 1$ 回静注) 低血糖は, 血漿 $\mathrm{GH}$ を $38.7 \pm 6.9 \mathrm{ng} / \mathrm{ml}$ (最高値, 以下同じ)に上昇せしめたが, 第 1 刺激として $\operatorname{arginine}(0.5 \mathrm{~g} / \mathrm{kg}$, 30分間点滴静注)を投与した後の第 2 刺激として与えられた場合には, 14.5 $\pm 6.5 \mathrm{ng} / \mathrm{ml}$ の反応を示すにすぎなかつた。この際, 血糖の低下度, 低血糖の回復の速さには差はみともら れなかつた。 FFA は第 2 刺激として与兄えれたときには，その低下度が少なかつた。てれに反して， Insulin $(0.10 \mathrm{U} / \mathrm{kg})$ 低血糖刺激を反覆して与光た場合には，第 1 刺激汶対する $\mathrm{GH}$ の反応 $(32.0 \pm 3.9$ $\mathrm{ng} / \mathrm{ml})$ と第 2 刺激に対する反応 $(31.1 \pm 3.4 \mathrm{ng} / \mathrm{ml})$ の間に差はみとめられなかつた。乙の場合, 低血桾 は, 第 2 刺激の場合にやや軽度である傾向があり, FFA は, 前述の場合と同様に, 第 2 刺激の場合には, その低下が著明でなかつた。 Arginine (30g) を 2 回反覆して与えた場合には，2 例においては, 第 1 の反 応が大で, 第 2 の反応が比較的小であり（21.1対 $8.3 ， 38.6$ 対 $9.2 \mathrm{ng} / \mathrm{ml}), 2$ 例では比較的小さな反応が同 様にみられた $(8.4$ 対, $8.3,9.4$ 対 $9.2 \mathrm{ng} / \mathrm{ml})$. 前值の高かつた 2 例 $(7.7,6.3 \mathrm{ng} / \mathrm{ml})$ では, 第 1 反応が 小で, 第 2 反応が大であつた $(2.4$ 対, $30.2,14.4$ 対 $27.2 \mathrm{ng} / \mathrm{ml})$. 血墏 $\alpha$-amino 酸は, いづれの場合でも 両回同様の上昇を示し，血糖，FFA 飞は本質的と思われる差はなかつた，以上の成績は, arginine による 血墏 GH の上昇は主として GH の放出により，insulin 低血糖によるものは，放出とともに合成をも伴 つておてる可能性を示唆する。(GH は NIH-HS-1147BC を標準として用いた).

追 加：阪大第一内科 岡田 義昭 Craniopharynigioma 患者で, insulin 低血糖刺激には反応するが, arginine 負荷には反応する，いわゆる反応解離型 HGH 分泌障害患者において，病状が進行するにつれて， この arginine 負荷による反応も消失したととを経験し, arginine と Insulin とでは receptor の解剖学 的な位置に違いが存在するのではないかという speculation をもつている，ての点先生の御報告とあわせ て興味深く, 追加させて頂きました。 
質 問: 京大第二内科 加藤 譲 インスリンとアルギニンに対する HGH の反応の解離はわれわれ も時に認めているが，そのような症例は何らかの間脳下垂体障害のあると推定される症例に多い. インスリ ンとアルギニンの作用部位の相違をはつきりしめすような間脳, 下垂体系のある部位が特異的に障害された 症例を経験されたととはないか.

応 答: 北大第二内科 中川 光二 正常人における arginine 及び insulin 低血糖に対する反応におい て， arginine に対する反応のばらつきが，insulin 低血糖に対する反応のばらつきよりも大きいが，一方に 反応し，他方にまつたく反応しないととはなかつた。臨床例においては, 第 1 に, corticosteroids 過剩状態 (endogenous のものとしては Cushing 症候群, exogenous のものとしては corticosteroids 剤長期投与例) のある種の場合に arginine に対し反応し, insulin 低血糖に対する反応が低下するのを観察した. 第 2 に, 視床下部に異常があると考えられる 1 症例で，同様の反応の解離があつた．

質 問: 東北大鳥飼内科 三浦 清 私共の経験では数例の Cushing 症候群の症例に於て（腺腫例, 過形成例共に) いずれも HGH は insulin, arginin の両方に対して反心が低下しているという結果を得て いる. 術後には arginin に対して速かに反応を回復して来るようです. Insulin に関しては, 治療後の症例 では例数が未だ十分でないので断定しない.

応答：北大第二内科 中川 光二 われわれの検查しえた Cushing 症候群 2 例（いづれも副腎腺腫） のうち 1 例では arginine に対し反応, insulin 低血糖に対し無反応であり, 他の 1 例では, 両刺激に対し 無反応であつた Cushing 症候群の1部において, 上記 2 反応の解離のあることは, 最近 Strauch らも報 告している (Acta endocrinologica 1969年 1 月号).

78. SU-4885 投与下の Human Growth Hormone 分泌動態

北大第二内科 国田 晴彦, 沢野 真二, 中川 光二, 武部 和夫 中江病院瀬田石智敏

SU-4885 (以後 SU と略す) の人成長ホルモン $(\mathrm{HGH})$ 分泌効果と, Negative Feedback による $\mathrm{ACTH}$ 分泌効果との関連性を検討した. 健康成人男子 5 人を用いて, 14 時間絶食, 2 時間前より安静臥床 させ，SU 1.5gr を経口投与し，30分間隔で 4 時間採血した。 血墏 HGH は二抗体法により，また ACTH 分泌の示標として血漿 11-Desoxycorticosteroids (11-DOCS) を Competitive protein binding Method

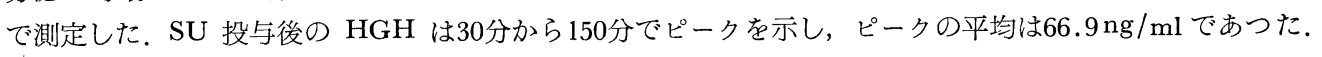
血糖は60分から90分で一過性の増加を示し, 血墏 11-DOGS は60分より上昇し始め, 120分以後 plateau と なつた. SU 投与後30分から60分の間に軽い胃痛の他, 発汗, 意識もうろう等の Insulin による Hypoglycemia の症状と同様な症状が出現したが90分を過ぎてほとんど消失した．次に Dexamethasone 4mg を 静注し，1時間後に SU を投与した，HGH はSU 単独投与時に比し，やや抑制される傾向であるが増加 を示し, ピークの平均は $41.8 \mathrm{ng} / \mathrm{ml}$ であつた. 血漿 11-DOGS はほとんど増加を示さず ACTH 分泌はこ の条件では抑制されていると見なしえる. SU 投与前 30 分より $30 \mathrm{gr} / \mathrm{hr}$ の速度で 4 時間 Glucose を点滴 静注したととろ, SU の $\mathrm{HGH}$ 分泌効果は全くみられず, 発汗等の副作用も出現しなかつた. この時の血 漿11-DOCS は SU の単独投与時と同様の上昇を示した. これらの結果より, SU の HGH 分泌作用は, Negative Feeback による ACTH 分泌作用とは異なつた機構で発現すると思われる. その機序に関しては 不明であるが，今後検討していきたい。

質 問：岡大第三内科 高原 二郎 同一人に metopirone 負荷以外飞他の stresser (Pyrogen Insulin etc）の負荷された事があるか. その時の HGH の反応性に差は認められたか. 私は Metopirone 負荷時と Pyrogen 負荷時の間に Plasma cortisol の反応性に大きな相違が認められることがある。もし HGH 亿 反応に相違が認められるとしたらその相違の起る機序は作用時間及び大きさの違いによると考えられるか又 は分泌機序の違いによるものと考朰れるかお教え願いたい.

応 答: 北大第二内科 国田 晴彦 1.今回は行なつていない. 2. SU の精代謝に対する作用が関与 しているという印象をもつているが，今後検討したい. 
追 加：神大第二内科 松岡 㻤 ACTH による GH 分泌機序は現在判然としないが，(1) ACTH 投 与により GH 分泌に先立つて IRI の分泌が起る事より insulin による影響も考えられる. (2) 投与された ACTH による下垂体前葉に対する直接作用とも考えられる。乙れは, 特に Steroid で supression して ACTH を投与した場合, 強く HGH の反応が現われる事から推察される. 然しいづれにしても, AGTH に対する GH の分泌機序は, 更に検討を姴するものと考えている.

79. 血中遊離脂酸と成長ホルモン分泌関する研究

東大中尾内科 対馬 敏夫, 松崎 宸, 入江 実, 中尾 喜久 前回までに我々は血中遊離脂肪酸（FFA）の低下に伴う GH の動態について報告した. 即ちニコチン酸 あるいはサリチル酸を投与して血中 FFA を低下させると，てれ伴なつて血中成長ホルモン $(\mathrm{GH})$ の上 昇が認められ，へパリンを同時に投与して FFA の低下を阻止すると GH の上昇は抑制される。このとと から NEFA の低下と GH 分泌は密接な関係にあると考元られる。. 今回我々は in vitro で脂肪酸酸化促 進作用を有するというカルニチンが血中 NEFA の軽度低下と共に GH 分泌を增す事を見出したが，ての 場合もへパリンの同時投与で FFA をたかめると $\mathrm{GH}$ 分泌は抑制された。 ての様に，低血桾に対する $\mathrm{GH}$ の反応と, NEFA の低下に対する GH 反応には類似している点がある。そてで正常人 5 例につきへパりン 1000単位を静注して以後の NEFA，GH を観察した。血中 NEFA は30分後には前值の 200〜300\%に上昇 し以後急激に下降してくるが，てれに伴なつて GH の著明な上昇が認められた。すなわち糖負荷後の Secondary rise に相当するものが NEFA の場合にも認方孔れた。この GH 分泌が NEFA の降下による かぞうかを見るために，更に60分，90分に Heparin を投与して NEFA を高いレベルに保つと，乙の間 GH 分泌はおきなかつた。したがつて GH 分泌はての場合 NEFA の下降関係すると考孚られる. 以上 の如く, 血糖の変動に於ける GH 分泌と NEFA の変動に対する GH 分泌々の間の類似性は興味深い. 以上の事実は，グルコースと NEFA が相補的に生体のエネルギー需要を満たしており，乙の均衡のとれな い場合には，GH が分泌されて NEFA を動員し需要に応ずるという解勫が成立つと思われる.

80. 肥満の研究 (第 4 報) 特に小児肥満における成長ホルモン反応について

熊大体質医研成人体質学研 陳内 富男, 宮尾 定信, 三村 悟郎, 定永 竹志, 中村 達男 小寺 稔, 福島 敬祐

Forsham らは肥満者の HGH は Arginine 投与によつてその免疫学的生長ホルモンの上昇が軽度であ つたと報告しているが，われわれは今回単純性小児肥満症について検討したので報告する. control は平均 年令 11 才, 平均肥満度 0.98 の男子 16 例である. 単純性小坚肥満症は男子 4 例, 女子 7 例, 計 11 例である. 乙 れらに glucose $(1.75 \mathrm{~g} / \mathrm{kg})$ を経口的に, Tolbutamide $(20 \mathrm{mg} / \mathrm{kg})$ を静注により, Arginine $(0.5 \mathrm{~g} / \mathrm{kg})$ を 点滴により投与し，HGH，IRI, NEFA, Blood, Sugar を測定した。 1) Glucose 投与について：HGH は Control と大差なかつた. IRI は肥満児の反応增大がみられた。 NEFA では, control に比し下降が少なか つた. B.S には大差なかつた。 2) Tolbutamide 投与について：HGH は肥満巟の方の増加が Control に 比して少い傾向にあつた，IRI は肥満児の方の増大が大であり，NEFA の下降は control の方が大であつ た. 3) Arginine 投与によつても HGH の増加は Control に比し少い傾向にあつた. IRI は肥満児に增 加が大きかつた．NEFA の低下は肥満览において下降の減少と遲延がみられた。血糖值は最初共にわずか の上早がみられたが，あと前值へもどつていた，以上より思春期前の単紝性小児肥満症においては HGH の 血中レベルの増加がやや軽度である傾向がみられるが，今後更に症例を増加して検討する予定である.

質 問：虎の門病院内分泌科 鎮目 和夫 私達がやりました思春期の正常人についての結果では, +20 \%位の肥満度数例では HGH 反応はあまり悪くなかつたが，+40\%，+50\%という様に肥つているものでは 或は悪いかも知れないと思う。

応 答: 熊大体質医研 陣内 富男 肥満度 $40 \%$ 以上の例が 4 例あり, うち 1 例が control 亿近い反応 を示していたが，その原因については更に検討して報告したい． 
81. 副甲状腺と腎の代謝：I . ラット謷 (in situ) の pyridine nucleotides redox state におよぼす血液 $\mathrm{Ca}$ 值の影響

東大吉利内科, 立石中研生物 尾形 悦郎, 鈴木 秀郎, 西木 克侑, 小林 茂樹, 立石 一真 腎における副甲状腺ホルモン効果の作用機序を明らかにする目的で一連の実験を行なつた。〔方法】 urethane 麻醉ラットの腎を血行を障害するととなく固定し, 表層 tubulus の pyridine nucleotides redox state を著者らの開発した microfluorometer で monitor し, 経時的に連続記録した. これは chanceらの fluorometer を (1) fluorescence signal $(366 \rightarrow 460 \mathrm{~m} \mu)$ のうち血液量変動による noise を light scattering signal を cancel するととにより除去する。（2)光源安定化と応答時間短縮化のため直流法とする．の 2 点 で改良したものである。また, plethysmograph 法により腎血液量の変動を monitor し連続同時記録し, 尾静脈より同時採血した血液 Ca 濃度を atomic absorption spectrometry で測定した。〔結果】(1) Parathormone-Lily 6〜40 単位責注により，10秒以内に始まり約 10分間持続する pyridine nucleotides redox state の還元方向への shift がみられた。乙の変化は腎血液量・血液 Ga 漲度の変動を伴わなかつた。(2)同 様の pyridine nucleotides redox state の一過性還元は, 無処置ラット・副甲状腺摘出ラットにおいて $\mathrm{CaCl}_{2}(120 \mu \mathrm{M}), \mathrm{HCl}(250 \mu \mathrm{M})$ 静注によつても惹起された. $\mathrm{CaCl}_{2}$ 静注による高 $\mathrm{Ca}$ 血症は少くとも10分 間は持続するが，redox state の shift は 5 分以内に回復した。 (3) EDTA $(40 \mu \mathrm{M}), \mathrm{NaHCO}_{3}(500 \mu \mathrm{M})$ 静注は, redox state の一過性酸化を惹起した。〔考按および結論】(1)副甲状腺ホルモンの作用をうけた腎 に篗測されるもつとも早期の反応は tubulus pyridine nucleotides の一過性の還元である。(2)ての副甲状 腺ホルモン効果は $\mathrm{Ca}^{++}, \mathrm{H}^{+}$投与で mimic される。(3) $\mathrm{Ca}^{++}$効果は血液 $\mathrm{Ca}$ 濃度と直接関係なくおそら く細胞内 $\mathrm{Ca}^{++}$濃度上昇に伴なう代謝の steady state の推移を反映するものと思われる。(4) $\mathrm{Ca}^{++}$効果・ $\mathrm{H}^{+}$効果は副甲状腺を介さない。(5)副甲状腺ホルモン効果の発現機転に $\mathrm{Ca}^{++}$作用の関与しているととが示 唆される。

質 問：東大老年病 藤田 拓男 使用した parathormone は何か. 非特異的反応は除外出来るか.

応答：東大吉利内科 尾形 悦郎 使用したのは Lily-Parathormone である.しかし, こてに報告し た効果が parathyroid hormone の効果であるととは(1) 6 〜0単位で doseresponse 関係がある. (2) $\mathrm{H}_{2} \mathrm{O}_{2}$ 処置で, 生物学的活性を破壊すると，乙の反応は見られない。(3)他の Basic protein (histone, protenine) ではおこらない, などの理由から，ほぼ問題ないものと思う。この詳細については別の機会に報告する予定 である.

82. 副甲状腺ホルモンの酵素的不活性化

皘性副甲状腺ホルモン水解酵素の性状について

東大老年病 大畑 雅洋, 吉川 政己, 藤田 拓男, 折茂 肇 三共中央研 丸山 素弘

${ }^{125} \mathrm{I}$ 標識副甲状腺ホルモン ( $\left.{ }^{125} \mathrm{I}-\mathrm{PTH}\right)$ を用いてラット腎の副甲状腺ホルモン (PTH) 水解酵素の性状 を検討した。 ${ }^{125} \mathrm{I}-\mathrm{PTH}, \mathrm{TCA}-\mathrm{PTH}$, 醉素標品を $38^{\circ} \mathrm{C}$ で 1 時間インキュベイトし, TCA 可溶分画の放射能 を測定した。 ラット腎ホモデネートの ${ }^{125} \mathrm{I}-\mathrm{PTH}$ 'ase 活性は $\mathrm{pH} 8.5$ と $\mathrm{pH} 11.0$ 亿至適 $\mathrm{pH}$ を有し, その

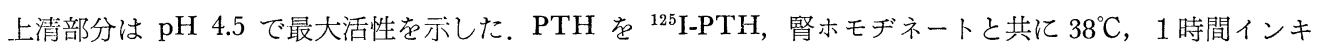
ヤュベイトし， PTH の残存生物学的活性を Munson 法により検定した結果は ${ }^{125} \mathrm{I}-\mathrm{PTH}$ 分解率から予測 されるPTH の量とほほ一致した。 ラットにおける ${ }^{125}$ I-PTH’ase 活性の藏器分布を脳, 肺, 心, 脾, 腎, 骨格筋等のホモヂネートおよび血漿で検討した結果, $\mathrm{pH} 4.5$ では腎と脾が同程度の比活性を示し, 肝, 肺 の 3 倍以上の強さであつた。 $\mathrm{pH} 8.5$ では腎が他臟器よりはるかに強い比活性（単位たんぱく当りの活性） を示した，血漿には全く活性がみとめられなかつた，細胞内顆粒を Shibko と Tappel の方法にならい，核， リソソーム, ミトコンドリア, ポストミトコンドリア, ミクロソーム, 上清部分に分別分離し, 各分画にお ける ${ }^{125} \mathrm{I}$-PTH'ase 活性を測定した。その活性は $\mathrm{pH} 4.5$ では上清分画に $\mathrm{pH} 8.5$ ではミクロソームに大部 
分存在し, 比活性は $\mathrm{pH} 4.5$ ではリソソームに最も強く, $\mathrm{pH} 8.5$ ではミクロソームに最も強かつた。 $\mathrm{Co}^{++}$, $\mathrm{Mn}^{++}$が EDTA 処理腎ホモデネートの酳素活性を増強した。 各種阻害剤に対する態度から ${ }^{125}$ I-PTH'ase はトリプシンあるいはキモトリプシンとは異なるようである。カルボキシペプチダーゼにも否定的な成績を 得た. 牛血清アルブミン, 変性へモグロビン, カゼイン, 妊馬血清ゴナドトロピン, 変性および未変性チト クロームを各々添加して ${ }^{125} \mathrm{I}-\mathrm{PTH}$ 分解をみたとてろ, 変性チトクロームが TCA-PTH 添加時と同程度の ${ }^{125} \mathrm{I}$-PTH'ase 活性阻害作用を示した。すなわち ${ }^{125} \mathrm{I}-\mathrm{PTH}$ 'ase は TCA-PTH のみならず変性チトクローム をも分解する可能性がある。

質 問 : 群大内分泌研 松崎 茂 (1)分解産物の同定をしているか. (2)非酥素的な分解の可能性はない 功.

応 答: 東大老年病 大畑 雅洋 (1)分解産物の同定は行なつていない. (2)酥素標品非添加でインキュベ イトした場合の TCA 可溶分画の cpm (0-time blank) は 4000c/min 位あつた。成績はこの 0-time blank を差引いたものである。 ${ }^{125} \mathrm{I}-\mathrm{PTH}$ の腎ホモヂネートによる分解が酵素によると考えられる理由は以 下の通りである。すすわち(10605分あるいは $80^{\circ} 5$ 分で加熱処理した腎ホモデネートは ${ }^{125} \mathrm{I}-\mathrm{PTH}$ を分解し ない. (2)透析された腎ホモヂネートは ${ }^{125} \mathrm{I}-\mathrm{PTH}$ を分解する。 (3) DFP などの阻害をうける.

83. 上皮小体機能の克進が実験的咬合性外傷におよぼす影響に関する研究. とくに，上皮小 体と副婜皮質機能の相関を考慮して

大阪歯大歯科保存 池田 克己, 河見 忠雄, 福島 重紀, 奥田 久平, 英 政夫 木村 健一, 坂珖

上皮小体機能の異常が骨組織の形態と機能に及ぼす影響のきわめて大きいととは周知のとおりである，そ てでわたくしたちは骨組織に比較的ちかい歯周組織に着目し, てれを歯周病学の立場から攻究したい為に, 雨牙に外傷性咬合を誘導し則局所場で異常を惹起させるとともに，他方上皮小体ホルモンの過剩投与によつ て上皮小体〜副腎皮質との関連をも併せ検討しつつ，乙れらが全身的，局所的変化によつて歯周組織に及ぼ す影響の程度についててれを内分泌学的な立場から観察した。試獣は Wistar 系雄ラット（体重 140〜170g) を用い, 実験群の構成は 1 , 対称群 2 , 甲状腺と副甲状腺剔除群, 3 , 副甲状腺ホルモン投与群 (PTH ; P-20) とし, 実験日数は各実験群とも 3 日， 5 日，10日の 4 群にわけて比較観察した。 また副甲状腺ホルモ ンの投与量は 10 I.U.とし, 毎日脊部皮下に注射した。観察の方法は血清ならびに顎骨での総 $\mathrm{Ca}$, 無機燐, 血液クエン酸值と，血清 ALP-ase, ACP-ase, LDH, GOT, GPT についておのおの測定した。また副腎機 能は in vitro によつて副腎の Corticosterone $(\mu \mathrm{g} / 100 \mathrm{mg}$ adrenal) 産生量を甲状腺, 副甲状腺を剔出し たものと対比し観察した，以上それらの結果は血清顎骨ともに総 $\mathrm{Ca}$, 無機燐, 血液クェン酸值は, 副甲状 腺ホルモン投与 3 日目がもつとも低く以後日数の経過にしたがつて増加する。しかし GOT, GPT を除い た ALP-ase, LDH の酵素活性はホルモン投与後 3 日目がもつをも高く, 以後日数の経過に従つて減少する 傾向が認められたが，いづれも対照群に比較してその活性度は高值をしめした。副腎 Corticosteron 産生量 はP－20の10日，20日間投与では，対照群に比較して著しくその産生量は低いが， 3 日， 5 日目までは軽度 な增加が認められた。 しかし甲状腺, 副甲状腺を剔出すると逆に対照群に比較して, 日数の経過に従つて著 名に増加する傾向が指摘しえた。

84. 内分泌疾患に於ける骨代謝異常

$$
\text { ことに糖㽷病について }
$$

名大第一内科 浅野 晴義, 藤田 徹, 富田 明夫

インスリン欠乏状態が骨の成長発育に阻害的に衝くことはよく知られているが，糖尿病患者の骨ひ薄化に ついては異論も多く, 糖尿病状態と骨代謝の関係は未だ明らかでない. 我々は病理解剖を行なつた18例の糖 尿病患者の肋骨横断面の Microradiograph 撮影を行ないその全体の面積に占める骨質の量の割合を精確に 測定し Mineralized Area Percent (MA\%) と名づけた. 又, Jowsey の Criteira に従つて顕微鏡下に 
Resorption, Formation の量を湿定し, Bone Remodeling の指標とし，それぞれ同年代の正常者との比較 検討を行なつた。 その結果, 糖尿病コントロールのよい群では MA \%は正常者と殆ど変らず, 腎障碍, 肝 硬変を合併したもの，コントロールのわるい群では，骨ひ薄化の傾向が明らかであつた．てれは骨のTurnover の面からみると Formation は各群とも大差はなく，Resorption の巟進によるものであるととがみ とめられた。一方, 2 年以上の経過をもつ通院加療中の糖㽷病患者37例をえらび, 右第 2 Metacarpal Bone 中央部の Cortical area の割合を計算し, 同年代の正常者群の平均と比較検討した。 その值は先の Microradiograph を使つた例と略々平行した結果が得られた。このととより，糖尿病の存在自体が骨ひ薄化に結 びつくととはないと考えられる。しかし婜障碍, 肝硬変を伴つた場合, 又, 一定期間糖尿病状態のコントロ ールが不充分である場合に Resorption の立進により骨は，ひ薄化の傾向を示す，従つて，糖疗病患者全体 としての Osteoporosis 発生の頻度が高率であるとすれば，それは糖㽷病疾患が，乙れ等合併症を伴い易い 状態にあるととから説明される。

85. non-functioning parathyriod cysts の 2 例

慶大外科 古屋 四郎, 三村 孝

我々は最近 8 年間に 4 例の上皮小体囊腫を経験した。同期間中に頸部囊腫として branchial cleft cyst を 27例, thyroglossal duct cyst を15例及び頸部胸腺囊腫を 1 例経験している. 上皮小体囊腫は世界的にみて 60数例, 我が国でも8例の報告をみるに過ぎない，我々の結果からすると，報告にみられるよりはるかに高い 頻度で発生していると想像される，上皮小体囊腫という用語を使用するにあたつては，腺腫や Hyperplasia の 2 次的変化による囊胞化は除外すべきであると考光，次の如き定義を定めた．1）発生部位が正常の上皮 小体の存在範囲内であること 2 ) 線維性結合織からなる囊腫壁の中及びその外側に, 定型的な上皮小体組 織がみられる，3）内面は一層の立方状又は扁平円柱状の上皮で覆われていること．臨床像としては, 無症 候性腫瘤であり, Scintigram 上甲状腺の圧迫像を，又頸部X線写真上気管の偏位は認めるが，その他血液 化学成分・朋機能等には異常を認めない. 手術時の所見としては, 周囲組織とほとんど療着のない, 壁の薄 い囊腫であり，全例簡単に摘出されている，ての発生起源については，現在は一種の貯溜囊腫であるとの考 えが支配的である．乙れは正常の上皮小体に小囊胞が高率に見出されるととを根拠としている．従つて内面 の上皮は上皮小体組織の細胞層であるという考えである，確かに類似点も多いが，大きさ・染色性・核小体 等の点で一致しない所見も多い，同じ稀れな囊腫である頸部胸腺囊腫の上皮と比較してみると，両囊腫の上 皮は良く似ている点が多い，胸腺と下上皮小体は，発生上極めて密接な関係にあり，共に胎生期には胸腺咽 頭管に接しているという，従つて両囊腫共に胸腺咽頭管の遺残より発生するという考えが妥当ではないかと 考えられる.

追 加：名大第一内科 富田 明夫 症例は34才男性で数ケ月前より前頸蔀の腫脹に気づく. 心悸圥進, 振せん, 発汗過多など甲状腺機能元進症の症状やその他高 Ca 血圧を思わせる症状は見られなかつた。 $\mathrm{BMR}+15 \% ， \mathrm{I}^{131}$ 甲状腺摂取率 $58 \%$ (24時間) $\mathrm{T}_{3}$ suppression test による $\mathrm{I}^{311}$ 甲状腺摂取率 $24.7 \%$ (24時 間) Triosorb $30.5 \%$, 甲状腺右葉部に $3.5 \times 3.0 \mathrm{~cm}$ の cystic の腫瘤を触れ, 穿刺により約 $5 \mathrm{cc} の$ 血性液を採 取した。 その後腫瘤の切除術を行ない組織学的に副甲状腺 cyst と診断した。本症例の術前の血清 $\mathrm{Ca}, \mathrm{P} な$ ど測定していないが，副甲状腺機能異常を思わせる症状もなく，手術により副甲状腺 cyst と診断し得たも のである.

86. 欠 演

87. 機能立進症状を伴つた原発性副甲状腺癌

東北大葛西外科 的場 直夫, 菊地 㥲朗, 田口 喜雄 焦飼内科 古川洋太郎

病理笹野 伸昭

$36 才$ 男子, 約 3 年前から妄想等の精神症状をきたし, 精神科で入院加療されたが, 昭和43年 2 月から全身 僚怠, 食思不振, 上腹部痛次いで右下肢痛, 歩行障害, 多飲多尿を来たし, 右頸部に腫瘤をふれた. 検查成 
績は血清 Ca $6.9 \mathrm{mEq} / \mathrm{L}$, 血清 P $3.9 \mathrm{mg} / \mathrm{dl}$, Al-P 74 (KA) と高カルシウム血症を示し, 尿中 Ca $535 \mathrm{mg}$ / day, 一日尿排泄量 4000cc, PSP 15 值 5\%, 残余窒素 $53.6 \mathrm{mg} / \mathrm{dl}$, 尿素窒素 $30 \mathrm{mg} / \mathrm{dl}$. X線像は肋骨, 手 指骨, 大腿骨頭, 脛骨, 腓骨等に脱灰, 骨膜下吸仪像, 譱胞状変化が著明で左右第三肋骨に病的骨折を認め 所謂汎発生線維性骨炎の所見を示した。又両腎には Nephrocalcinosis がみられた。原発性副甲状腺機能六 進症と䛦断し，昭和43年 8 月 7 日甲状腺右葉とともにその下極部にあつた腫瘍を全摘した。尚腫痬は甲状腺， 筋, 内頸静脈, 総頸動脈と癒着を示した。摘出腫瘍は $3.5 \times 3 \times 2.8 \mathrm{~cm}$ 大で表面凹凸不平で硬く, 割面は圧黄 色で囊腫化し, チョコレート様の内容を持つていた。組織学的には, 一般に Chief·Cell 様を呈し副甲状原 発が示唆され，核は時に大小不同があり，巨大核もあるが mitose は極めて稀である。また一部では乳頭状 の配列もみられ Psammoma Body および間質の石灰化もみられた。間質や被膜の線維增殖は極めて著明で 脈管内等には腫痬細胞の侵襲像がみられた。又周团の横紋筋内にも明瞭な侵潤性発育があり癌の確診を得た。 術後 1 ケ月で尿量 $2000 \mathrm{cc}$ 前後と減り 4 ケ月で単独歩行が出来る様になつた。血清 Ca は術後急速に低下し 8 ケ月（昭和44年 4 月）の現在も $4.0 \mathrm{mEq} / \mathrm{L}$ と正常值を示した。骨変化はなお残存するが著明に改善された. なお右頸部に転移を疑わせる硬いリンパ節を触れる。

質 問 : 東大吉利内科 尾形 悦郎 この症例の特徴は (1)術前の血清 $\mathrm{Ca}$ ともに $\mathrm{P}$ も高い。(2術後, TRP が回復してない，の 2 点にあるように思うが，その説明をお教光願いたく存じます．

応 答: 東北大鳥飼内科 古川洋太郎 術前の検査時には, 著明な脱水状態があつたため, 腎機能の低下 による高燐血であつたと思われる，術後，血清 Ca が low normal であるにもかかわらず，尿中燐排沮が 是正されないのは, 血清 $\mathrm{Ca}$ が高值を示さ奴点より再発の為とは考光られず, アルカリ・フォスファター ゼが依然として高く，血中燐が低いてと等から，尿細管機能異常による phosphate leak を合併している可 能性も否定しがたい，数年前，われわれは同様に尿細管機能異常を合併した原発性副甲状腺機能六進症を経 験し，すでに報告している.

88. 上皮小体およびサイロカルシトニンとVitamin D との関連について（第 3 報） 上皮小体ホルモン欠除時におけるサイロカルシトニンおよび Vitamin D 作用について

$\begin{array}{cll}\text { 岩手医大瀬田外科 } & \text { 瀬田 } & \text { 孝一, 阿部 実, 岡野郁二三 } \\ \text { 小児科 } & \text { 若生 宏, 皇山 富而 } \\ \text { 粜学部口腔病理 } & \text { 鈴木 鍾美 } & \end{array}$

内因性上皮小体ホルモン (PTH) の慢性的欠乏時におけるサイロカルシトニン (TCT) およびビタミン D (VD) の骨におよぼす影響について検討した。実験動物は体重 $100 \mathrm{~g}$ 前後の Wistar 系雄ラットを用い, 上皮小体摘除 $(\mathrm{PTX})$ あるいは上皮小体・甲状腺摘除 $(\mathrm{PTX}+\mathrm{THX})$ を行ない，1) Control，2） PTX, 3) PTX+VD 欠乏, 4) PTX + TCT + V.D 欠乏, 5) PTX+V.D 過剩, 6) PTX + TCT + V.D 過剩, 7) $\mathrm{PTX}+\mathrm{THX}$, 8) PTX+THX + V.D 欠之, 9) PTX + THX + TCT + V.D 欠乏, 10) PTX + THX + V.D 過剩，11）PTX+THX+TCT + V.D 過剩の各群に分けた。実験期間は 4 週間とし，手術翌日より，V.D 欠忌は Harrison らによる欠浪飼育により，V.D は Calcifero（1日 $1.25 \mu \mathrm{g} / 10 \mathrm{~g} /$ 体重を，THX ラット には Thyrasin 1 日 $300 \mu \mathrm{g} / 10 \mathrm{~g} /$ 体重を経口的に TCT は毎週 1 回 $200 \mu \mathrm{g} / 10 \mathrm{~g} /$ 体重を筋肉内にそれぞれ投 与した。これら各群について，その大腿骨々頭部骨端を硝酸アルコールで脱灰後，ツェロイデン・パラフィ ン二重包埋法により切片標本を作製し，大腿骨々端軟骨細胞層について検索した結果，PTX 群あるいは PTX+THX 群では, V.D の欠泛あるいは過剩いずれの場合においても腫大細胞の萎縮, 化骨化, Osteoblast の減少などをみるが，てれらに TCT を投与するととにより，腫大細胞の増加，化骨化の減少， Osteoblast の増加など, 対照群に類似の所見を示した，以上の所見から，内因性 PTH の欠乏は，内因性 TCT あるいはV.D の久乏を伴うことにより，骨に対して強い影響をおよぼすてとを認めた。しかし，か かる骨に対する作用が主に内因性 PTH によるか，V.D によるか，あるいは両者の相互作用によるかにつ いては，今後の検討を要する．また外因性 TCT が， PTH とV.D の欠乏した場合でも，その作用効果の 発現をみたととは，PTH あるいはV.D の関与がなくても，TCT 単独で作用するてとが可能であると推 
測される.ささに PTH の欠乏に対するV.D の過剩投与における骨組織所見が TCT の投与により改善 されるととは，TCT の臨床的応用を示唆するものと考えられる．

翼 問: 東大中尾内科 森井 浩世 Thyrocalcitonin の作用は比較的短く, 一旦下つた血清 Ca は 3 時 間位で注射前のレベルに 戻るといわれているが， 1 週間 1 回投与 4 週間の経過で血清 $\mathrm{Ca}$ はどのような変 動を示すか.

応 答：岩手医大瀬田外科 阿部 実 1) TCT 投与量については検討を要する。 2）TCT 投与後 の血清 $\mathrm{Ca}$ 值については, 投与後 1 週の検索で有意の変動はみられなかつた。

追 加: 東大吉利内科 尾形 悦郎 thyrocalcitonin の bioassay を行なつてみると, high dose でか えつて hypocalcemia の程度が弱くなつています。このととは, thyrocalcitonin のサンプルの中にかなり 大量の不純物があり，しかもそれが骨の代謝になんらかの影響を与えるものを意味している。したがつて， 演者の用いたような大量の thyrocalcitonin 製品の投与の効果の説明には，ての点の注意が必要と思われる.

89. 尿中燐排泄増加を指標とした Thyrocalcitonin 分泌刺激圾験について

東北大鳥飼内科 古川洋太郎

副甲状腺機能正常例に Ca 負荷試験を施行すると, Ca 負荷後, 尿中の燐は減少するが, 負荷直後, Thyrocalcitonin（TC）によると思われる一過性の尿中燐排泄の増加がみられる，Ca 負荷直後のかかる一 過性の燐排泄増加を TC 分泌刺激試験に応用する試みに関し, 若干の検討を加えて報告する. 方法は Goldsmith の急速 Ca 負荷試験に準拠する. 結験は 2 日間にわたり, 午前 8 時より10時まで各 1 時間尿を 2 回 採尿する. Ca 負荷は, 第 2 日の午前 9 時, 採尿直後, 体重 $\mathrm{kg}$ あたり Ca にして $3.5 \mathrm{mg}$ を 10 分間かけて静 注する，各1時間尿につきクレアチニン（Ucr） と燐（Up）を測定する．9時から10時までの1時間尿の $\mathrm{UP} / \mathrm{Ucr}$ を， 8 時から 9 時までの 1 時間尿の $\mathrm{Up} / \mathrm{Ucr}$ の per cent としてあらわし，てれを対照日と $\mathrm{Ca}$ 負荷当日とで比較し，その差，すなわち，Ca 負荷による燐排泄の増加率と自然の diurnal variation によ る燐排泄の増加率との差をもつて Thyrocalcitonin による効果と判定する，ての方法によると，Ga 負荷 による反応は，正常例（2 例）平均 $9 \%$, 原発性副甲状腺機能立進症（3例）平均 $9 \%$, 甲状腺機能克進症 （5例）平均 $49 \%$, 甲状腺機能低下症（1例） $9 \%$, Cushing 症候群（4例）平均 $41 \%$, 尿路結石症（18例）

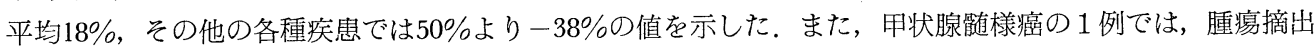
前 $95 \%$ と著明な高值を示し, 摘出後正常以下に減少したのは, この方法が甲状腺䯣樣癌の診断に役立つ可能 性を示唆する． Ca 負荷直後の尿中燐排泄の変動には，TGの効果とともに，副甲状腺ホルモンの分泌抑制 による効果が同時にあらわれる。したがつて，その結果は副甲状腺機能との相関に於て判断される必要があ り, 限界はあるが, 骨以外の作用部位における TC の効果を根拠とする点, 従来の血清 $\mathrm{Ca}$ 回復時間を指 標とした機能検査をおぎなう面をもつものと考えられる.

質問：東大老人科 折茂肇 副甲状腺ホルモンと副腎皮質との関係について control は thyroparathyroidectomy を行なつているか, 又は sham operation を行なつているか, 若しなければ nonspecitic stress による影響が考光られないか.

応答: 東北大鳥飼内科古川洋太郎 甲状腺摘出前後の症例で検查を施行したのは, 甲状腺蹃椂癌の 1 例のみである，甲状腺全摘例での检討を，今後予定している，サイロキシン投与による檢討は行なつていな い.

質問：東大吉利内科 尾形 悦郎 ब私ぞもも Ca 負荷試験で thyrocalcitonin の機能予備能の検査を 行なつているが，その際次の 2 点が気になつているわけで，その点のお考学をお教え願いたい（i動物実鈋 で thyrocalcitonin の phosphaturic 効果は，かならずしも確立していない. Reberison らは，ラットに crude な thyrocalcitonin を投与して phosphatuia を認めているが, 一方もつとも pure と思われる thyrocalcitonin について phosphaturia がないという報告もある。更に最近 Kenny らはイヌの腎動脈に thyrocalcitonin を直接注射して phosphaturia のおこらないととを示している. (ii) Ca を負荷すると $\mathrm{Mg}^{++} \mathrm{Na}^{+}$など多量の電解質の排泄がみられ，乙れが, phosphaturia に影響する可能性はないか。 ®副 
甲状腺機能立進症で phosphaturic response の高いものがありますが，てれはどのように説明されるか. 応 答: 東北大鳥飼内科 古川洋太郎 1. 最近 TCT に燐排泄増加作用が認められなかつたという報告 があるが，乙の燐排泄増加作用に関しては MacIntyre 以来報告も多く, 現在の段階では, 一応, 一般に認 められて居ると考兮，わたくしも，その事実に従つて成績を判断した，2. Calcium の負荷量は，必ず しも大量ではなく，Calcium 負荷による直接の腎に対する影響は比較的少ないと考えられる。3．副甲状 腺機能立進症の 1 例で多少燐排泄の増加した例があるが，尿中燐排泄の diurnal variation の再現性等の 問題もあり，本検査に於ては，乙の程度の増減は䛊差範囲の可能性がある。

90. Thyrocalcitonin (TCT) そ関する研究 (IV) 幼若ラット等を用いた TCT 生物学的検 定法の検討

東大中尾内科 森井 浩世, 井林 博, 中尾 喜久

今回主として幼若ラットを用い TCT の生物学的検定法を検討した。動物は Wistar 系については数個 所の業者からえられる雄, $2 \sim 6$ 週令, Sprague-Dawley 系については $3 \sim 6$ 週令, Holtzman 系は $2 \sim 5$ 週令のラットを用いた. 又比較のため $5 \sim 6$ 週令の各系マウスについても感度を検討した. 動物は $1 \sim 4$ 日 間主として 1 日間低 Ca 食で飼育，更に24時間絶食して実験に供した。標準ホルモンとして Wilson の

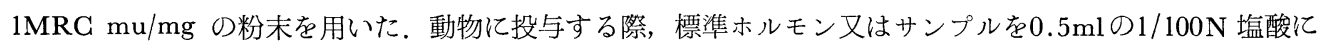
溶解，皮下注射60分後腹腔大動脈より採血，血清 $\mathrm{Ca}$ を原子吸光法又は Na Chlosanilate 沈澱法により測 定した. Wistar 系では幼若ラットで入值が低く検定に使用可能なものもあつたが安定した結果がえられな

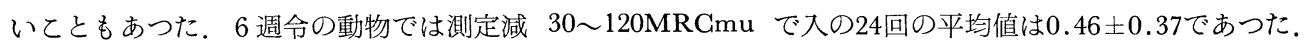
Sprague-Dawley 系は 3 週令のラットで最適測定範囲 5〜20MRCmu，入值は 6 回の実験で $0.20 \pm 0.04 ， 6$

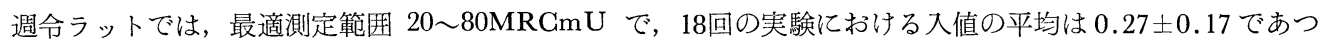

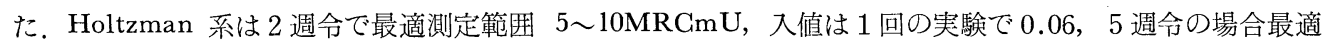
測定範囲 20 80MRGmU で，入值の平均は 13 回の実験で $0.27 \pm 0.07$ であつた。結局入手の容易さから Sphague-Dawley 系 3 週令ラットが最も適当な動物と思われる。 マウスは DBA, AKR，KK，G3H III， GFI, ddN 各系中 C3HIII が TCT 亿感受性を示した。 人出状腺中 TCT 抽出は1/10N塩酸で homogenize 後600g 30分，100,00g 60分で遠沈，上清を動物に投与した。正常人甲状腺は 6 例で 37〜275 MRG $\mathrm{mU} / \mathrm{gm}$ wet weight，29才女子髄様癌の転移リンパ組織から $9.4 \mathrm{MRG} \mathrm{u} / \mathrm{gmwet}$ weight の值をえた。血漿 中 TGT については脱脂正常血漿の $1 / 10 \mathrm{~N}$ 塩酸抽出物が標準ホルモンの反応と平行関係を示した. 伊藤病 院伊藤国彦先生, 東京都監察医務院吉村三郎先生, 東大第二外科藤本吉秀先生, 実験動物中央研究所野村達 次先生, 江崎孝三郎先生, 帝国臟器浅野英一氏, 島沢英一郎氏の御協力に感射します.

91. リン酸塩の thyrocalcitonin 作用増強効果について

東大老年病 折茂 肇, 藤田 拓男, 岡野 一年, 吉川 政己

ラットに於ける thyrocalcitonin (TC) の血清 Ca 低下作用が食餌中の燐酸塩含量により大なる影響を うけ又中性燐酸塩を TC と共に若ラットに皮下注射をすると TC の血清 $\mathrm{Ca}$ 低下作用が著明に増強され る事は既に Hirsch により指摘されている，吾々はての作用につき更に検討を加え中性燐酸塩の TC 増強 作用が Wistar 系若ラットに於てのみならず TC に対する感受性の極めて低い老ラット（生後1.5年）に於 ても又予め甲状腺副甲状腺剔除を行なつた若ラットに於ても認められる事を見出した，更に骨組織培養法 (Goldhaber 変法) を用いて中性燐酸塩の添加により副甲状腺ホルモンにより誘発された骨吸収が著明に抑 制される事，及びTGの骨吸収抑制作用が中性燐酸塩添加により更に増強される事を証明した。中性燐酸塩 の TG 増強作用の機序はかならずしも明らかではないが，中性燐酸塩が TCの骨 Ga 沈着作用を増強させる 可能性が考えられる。ピロ燐酸は生体の種々の反応過程に於て生成され最近では人の血液，尿中にも微量な がら存在する事及びてれが in vitro, in vivo に於て石灰化を抑制する因子である事が Flesch らにより指 摘されている。吾々はWistar 系若ラットに pyrophosphate $4 \sim 1024 \mu \mathrm{mols}$ を皮下注射し dose dependent な血清 $\mathrm{Ca}$ 低下作用を認めた。この作用は投与後 1 時間附近で最大で，予め甲状腺副甲状腺剔除を行なつ 
たラットに於ても認められた，更に pyrophosphate を TG と共に皮下注射した場合，TGの血清 Ca 低下 作用が著明に増強される事が見出された。中性燐酸塩と pyrophosphate の TG 増強効果はほぼ同程度と 認められた. pyrophosphate の TC 増強作用の機序は不明であるが， pyrophosphate が石灰化抑制因子で ある点を及び骨組織培養で著明な骨吸収抑制作用を有する点から TCの骨吸収抑制作用を増強させる事が示 唆される。

質問: 東大吉利内科尾形悦郎 (1) in vitro の骨 incubation 実験で, Pi 単独は, 副早状腺ホルモ ンの bone resorption を阻害しますが， $\mathrm{Ca}^{45}$ release については Pi は副甲状腺ホルモンの効果を抑制し ていないように見えます。この discrepancy はどのように説明されるか. (2) pyrophosphate はどのルート で投与したか. (3) pyrophosphate はキレート剤であるので, その効果は@化学的 Ca 定量を妨害しないか (b) この効果はキレート剂にみられる非特異的な効果か.

質 問: 名大第一内科 富田 明夫 Pyrophosphateの添加実験で私共はラットのTibia の calcification の著明な抑制作用をみている。先生の実験で pyrophosphate の投与で hypocalcimia が見られるが，その genesis につき御教示下さい.

92. $\mathrm{Ca}$ 代謝調節に関する研究 IV

Thyrocalcitonin の効果におよぼす影響

帝藏薬理研 島沢英一郎, 浅野 英一 東大吉利内科 尾形 悦郎, 鈴木 秀郎

骨の $\mathrm{Ca}$ 代謝回転におよぼす androgen の作用を検討した。. Speague-Dawley ラットの雄及び雌の intact, 去勢又は卵巣摘除群に testosterone propionate $(0.1 \mathrm{mg}$ 又は $1.0 \mathrm{mg} \times 3$ 日) を処置し，その影響 をみたが，この様な薬理量の testosterone propionate (T.P) 投与は条件により有意の血清 Ca 低下を起さ せたが，明らかな dose-response 関係はみられなかつた。この様な T.P 処置に対する thyrocalcitonin (TGT) の感受性は, 雄ラットの intact 及び去勢では TGT の低 Ca 効果を10倍以上にも増大した。雌 ットの intact 及び均巣摘除に対しても, T.P 投与は TCT の効果を増強するが, 雄ラットに比べその効 果は弱かつた，かかる効果は，老令の雄ラットではみられなかつた。. Androgen 投与による血清無機りン酸 值の変動は, 血清 $\mathrm{Ca}$ 值の変動と相関々係がなかつた. Androgen による TCT 効果の増強は, リン酸代 謝とは無関係であり，他のルートで骨の Ca 代謝回転に関与すると考えられる。

質問：東大老人科折茂肇 (1) Estrogen (Premarine) は Dihydrofachysterolにより誘発された 高 $\mathrm{Ca}$ 血症を低下させる事実を認めたので追加する。 (2) androgen が TG の効果を増加させる機序は. bone resorption rate を変化させる可能性は. 又 TC の反応性は骨の exchangeable Ca pool size によ つても影響されるのでそれに対する効果も考える必要がある.

応答: 帝臓薬理研 島沢英一郎 androgen が示す態度は young と old で異り, また dose によつて も TCT に対する態度が変る点から bone 直接か否かはまだ明らかでない. androgenic な作用として下垂 体系への effect も考えその様な経とは無関係で hypocalcemic effect を越すかが問題であると考える.今 後この様な面の研究を更に行なつてゆきたい.

93. 心血管系のカルシウム代謝と副甲状腺ホルモン

東大老年病 岡野 一年, 藤田 拓男, 折茂 肇, 吉川 政己 加令により組織内のカルシウム含量が増加し，とくに心血管病変の発生と密接な関係があるととは周知の 事実である。われわれは心血管系のカルシウム代謝に関する研究として Na-Sulfaacetylthiazole (SAT) 投 与による心血管系変化を ${ }^{45} \mathrm{Ca}$ を用いて検討し, 内分泌学的見地から考察を加えた. SAT $0.5 \mathrm{~g} / \mathrm{kg} の ラ ッ$ ト腹腔内注射により間質性腎炎が生ずるが，生後 4 ケ月以上のラットではこの他に心筋炎・大動脈中膜壊死 ・石死化等の変化がみられた。しかし副甲状腺摘除又は高コレステロール食 4 週間飼育により腎障害を除い ててれらの変化は抑制された。 大動脈・心・腎のカルシウム含量は SAT 処置により有意の増加を示した。 $\mathrm{SAT}$ 処置後 3 日目に心 ・大動脈の ${ }^{45} \mathrm{Ca}$ 摂取が最大となるととから, SAT 処置後 3 日目に ${ }^{45} \mathrm{Ca} 20 \mu \mathrm{Ci}$ を 
ラット腹腔内に注射し 24 時間後各臟器を採取・灰化し, 各臓器の 24 時間内 ${ }^{45} \mathrm{Ca}$ 摂取量を gasflow counter にて測定した。大動脈・心・䀫の 24 時間内 ${ }^{45} \mathrm{Ca}$ 摂取量は SAT 処置により有意の増加を示した。しかし副 甲状腺摘除又は高コレステロール食飼育は腎を除く軟組織臓器のカルシウム含量及び ${ }^{45} \mathrm{Ca}$ 摂取量の SAT による増加を抑制した。猶又，高コレステロール食飼育により骨の 24 時間内 ${ }^{45} \mathrm{Ca}$ 摂取量が著明に減少する ことは，SAT そよる心血管病変の発生に対する高コレステロール食飼育の防止効果の機序への手がかりと して興味深く思われる. 次に ${ }^{45} \mathrm{Ca}$ を SAT 処置 2 週間前に投与し, 骨の安定分画中の ${ }^{45} \mathrm{Ca}$ に対するSAT の影響をみたが，生後 4 ケ月以上のラットで骨安定分画中の ${ }^{45} \mathrm{Ca}$ 含量は SAT 処置により減少した。乙れ は骨安定分画にあるカルシウム動員が副甲状腺ホルモンのみによつて行なわれるととから， SAT による急 性腎不全が二次性副甲状腺機能元進症を生し，乙れによる副甲状腺 ホルモン分泌の元進が骨安定分画中の ${ }^{45} \mathrm{Ca}$ の血中への放出を促したためと思われ，乙れらの病変が副甲状腺摘除により抑制されることからも， SAT による心血管病変の発生に副甲状腺が大きく関与するととを示唆する.

94. TSH の Radioimmunoassay に関する研究 エタノール食塭沈澱法と二抗体法の比較

$\begin{array}{lll}\text { 阪大中検 熊原 雄一 } & \\ \text { 阪大阿部内科 宮井潔, 福地稔, ○井上雅 }\end{array}$

Radioimmunoassay (RI-assay) は, 蛋白性ホルモン測定法の主流飞なりつつあるが TSH に関しても， Odell らによりその成功が報告され，一躍注目を集める様になった．現在我々も Condliffe の精製H-TSH, てれを抗原として作製した抗 TSH 家鬼血清 (1:20000，40\% bound) 及び標準 TSH として H-TSH R-STD-A を用い, 主に Ethanol-Saline 法による TSH の RI-assay を行ないつつあり, 本法が種々の点 で優れ，また臨床応用上も，十分満足し得るものである事を確め，先の本総会等で報告した。 とてろが Ethanol-Saline 法は経済的ではあるが，測定操作が煩雑で，大量の試料測定に難点があった。 そてで測定 法の簡素化を目的として，二抗体法につき種々検討し，合せて Ethanol-Saline 法との比較を行なったので， その成績につき報告した. 方法は EDTA 添加二抗体法を用い, 第二抗体には阪大微研製抗家鬼血清山羊血 清を用いた。本法による最小測定感度は $0.2 \mu \mathrm{U}$ で, Ethanol-Saline 法とほぼ同じでった。特異性につき， HCG, B-TSH, $\gamma$-Globulin 及び Albumin を用い検討, HCG, B-TSH, 及び Albumin については, 検 討範囲内では全く影響がみられなかったが，ヒト $\gamma$-Globulin 濃度が $50 \mathrm{mg} / \mathrm{ml}$ 以上となると影響を示す結 果を得た。これは実際の assay に際しては, 量的にみてまず問題ないが, 血中 $\gamma$-Globulin が異常に高值 を示し症例の測定に際しては，一応配慮が必要と思われる。精製 H-TSH 及び原発性用状腺機能低下症患 者血清の稀勫曲線は標準曲線と平行する事が確められ, 既知量の TSH を血清に添加した際の回収率は 99.6 $\pm 9.5 \%$, 同一血清試料を 4 回の異なる assay で測定した際の再現性については variation が士 $3.5 \%$ あっ た. Ethanol-Saline 法と二抗体法による血中 TSH の測定值の比較では, 両者がほぼ一致するものとの結 果をえた. EDTA 添加の可否についての検討では, EDTA を添加した方がよいとの成績であった. 以上 TSHの RI-assay としての二抗体法は Ethanol-Saline 法とほぼ同様の成績であることを確めたが, routine の測定法としては，種々の点で優れた二抗体法がよいとの結論を示した。

質 問: 京大第二内科 井村 裕夫 エタノール沈搌法ではたしかに液量が多くなるが, 液量をもう少し 少なくして測定する方法を試みたてとがあるか.

応答：阪大阿部内科 福地稔 Ethanol-NaCl 法は液量が多い点確かに問題だと思う. incubation medium 中の蛋白量の問題さえ解決すれば液量を少なくしうるのではないかと考えている。然し材料が貴 重なためその検討はしていない.

95. TSH の Radioimmunoassay に関する研究

免疫活性と生物活性の比較

阪大阿部内科 宮井 潔, ○福地 稔, 井上 雅, 阿部 裕
阪大中検 熊原 雄一


TSH の Radioimmuno-assay（RI-assay）は測定法として必要な種々の条件をそなえたものであり，今 後 TSH 測定法の主流になりうるものと思われる。ホルモンの本質は，その生物活性にあり，RI-assay も その生物活性を反映しているとの前提で意義があると思われる. 従って TSH の免疫活性（I）と生物活性 （B）を比較する事は，その RI-assay の価值を論ずる上からも，又 TSH の性状を知る上からも重要な事 と思われる。ところが現在てれに関した検討成績はなく, 結論がえられていない. 我々は血中 TSH および 種々の純度をもつ下垂体TSH そつき, RI-assay と Mckenzie の bioassay を用い, 同一の Standard 即ち H-TSH R-STD-A および自家製の laboratory standard を基に，乙の問題を検討，その成績につき報告した。 原発性甲状腺機能低下症（低下症）患者に $\mathrm{T}_{3}$, 又は $\mathrm{T}_{4}$ を投与し，その血中 $\mathrm{TSH}$ 值の変動を両測定法で 測定, 両活性を比較すると, $\mathrm{T}_{3}$ 投与例で $\mathrm{r}=1.00(\mathrm{P}<0.001) \mathrm{T}_{4}$ 投与例で $\mathrm{r}=0.96(\mathrm{P}<0.01)$ とよく相関す る成績をえた。 ところが両活性の比, 即ち $\mathrm{B} / \mathrm{I}$ は $\mathrm{T}_{3}$ 投与例で $5.9 \pm 0.5, \mathrm{~T}_{4}$ 投与例で $7.7 \pm 0.45$ といづ れも B 活性が高值を示す結果であった。他の末治療低下症 33 例につき同様の比較を行なったととろ, $\mathrm{r}=0.98$ $(\mathrm{P}<0.001)$ と両活性は有意の相関を示すととが確められたが B / は は $6.31 \pm 1.08$ B 活性が高值を示す成績 であった。一方下垂体 TSH に関し aceton powder, Bates' percolation 法の Fr. II, III, IV, 更に CMC fraction につき同様の比較を行なったところ, 血中 TSH 同様, 両活性が有意に相関するととが確めら

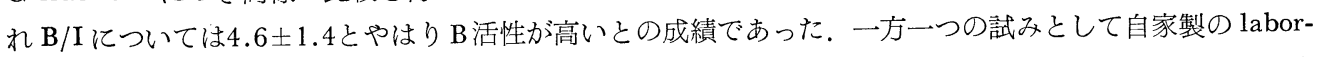
atony Standard を用い, 一連の同様検討を行なったととろ, 血中 TSH で B/I が $0.98 \pm 0.25$, 下垂体 TSH で $0.91 \pm 0.28$ と絶対值においても，よく一致するとの成績をえた. H-TSH R-STD-A を Standard とした際のB/Iの不一致に関し，测定試料，H-TSH R-STD-A および両測定法につき基礎的検討を加えた が明らかな理由を指摘することは出来なかった，以上の成績から，TSH における B，I，両活性はよく相関 すること，又絶体值についても一致するものであろうとの結論を示した．

96. ACTH の radioimmunoassay および bioassay における新しい試み

亲大深瀬内科 松倉茂, 井村 裕夫, 松山均

血中 ACTH は概めて微量であるため従来測定が困難でった。われわれは radioimmunoassay および bioassay において感度をあげうる新しい工夫を試み測定をより容易にしうるてとを明らかにした。まず radioimmunoassay において標識ホルモンの微量（1ないし $2 \rho \mathrm{g}$ ) と比較的高濃度の抗血清を incubateす ると從来用いられていた標識, 非標識ホルモンの抗体への競合的結合により得られる標準曲線よりも低濃度 の範囲で非標識ホルモンの増加に従ってかえって標識ホルモンの抗体への結合が定量的に増加するととを羿 めた. 従ってての奇異な現象を用いるととにより感度が高まり血漿 ACTH を抽出操作を行なうことなく直 接測定するととが出来た。 なお測定の特異性, 回修率も淽足すべきものであった。本法により測定した結果 正常人において血中 ACTH 值の日内変動 (午前 8 時平均 $68 \rho \mathrm{g} / \mathrm{ml}$ 範囲 22-175 $\rho \mathrm{g} / \mathrm{ml}$ ) を認め, dexamethasone 投与後 AGTH は低下し, metyrapone 投与により堌加（翌朝 8 時平均 $396 \rho \mathrm{g} / \mathrm{ml}$ 範囲 $170-780 \rho \mathrm{g} /$ $\mathrm{ml}$ ) した。 また下垂体機能低下症, 下垂体摘除患者, 副腎腫痬によるクッシング症候群では血中 ACTH は低下しており両側副腎皮質肥大によるクッシング症候群のため副霜全摘術をうけた症例, アジン氏病で はいずれも著明に増加していた。 また正常人に stress として bacterial pyrogen を投与した場合種々の程 度の血中 ACTH の上昇を認めたが発熱の度合, 副作用の有無と反応の間に関係が見られた。一方 bioassay においては propranolol が副需皮質の ACTH に対する反応を明らかに増強させるととを見い出した。 下 垂体摘出ラット末梢血中コルチコステロンを指標とする Guillemin 法, 重摘ラット副腎静脈血中コルチコ ステロンを指標とする Lipscomb-Nelson 法により bioassay の感度の上昇の度合を検討するとそれぞれ約 3 倍，2 倍弱ほど鋭敏になった。 以上述べた radioimmunoassay および bioassay における新しい試みは ACTH の測定をより鋭敏かつ容易にするものと考えられる.

質 問: 北大真下内科 瀬田石智敏 プロプラノロール前処置によりラットの全身状態が不良になり, 注 射するサンプル量を減らさなければならなかったというととはあったか.

応 答: 京大第二内科 井村 裕夫 Guillemin 法の場合試料注射 6 分前に propranol を $1 \mathrm{mg}$ 腹腔内 
に注射したが，ての量ではラットの全身状態に影響が見られなかつた。ただ Lipscomb-Nelson 法の場合に は若干副筒流血量の減少が認められた。

質 問：阪大西川内科 島 健二 1 . Standard curve における reverse portion の範囲はどれ位にな るか, もし reverse portion が狭い場合, ある B/F ratio が reverse portion にあたるものか, それ以後 に現われるであろう ordinel portion 保属するか，いかにして区別するか，

質問：阪大阿部内科 福地 稔 “reverse portion”の機序については不明との事であったが，現在 ぞの様に考えておられるかを教えていただきたい.

応 答: 京大第二内科 松倉 茂 (1) low diluted の抗血清を使用したが著明に reverse portion が みられるが high diluted でもわずかな傾向がみられる，又適当な抗血清で 1000 倍稀釈では 0-500 $\rho$ g の標 準 ACTH に対し B/F 比が増加し, 実際の值で $5,000 \mathrm{\rho g} / \mathrm{ml}$ となり充分の範囲を cover している。しか し B/F が高いときは $1 / 2 \sim 1 / 3$ の稀粎試料でも陚みる必要がある。(2) 現在明らかでないが，いままでの 二価抗体の他に分子量の多い多価抗体の因子を推測している．ての場合 allosteric effect がおこることが充 分考られる. 抗体の精製, 分画等により今後検討の予定である.

97. AGTH Radioimmunoassay (第 1 報)

$\mathrm{ACTH}$ 抗体の高頻度作製成功とその応用

東京医歯大大淵内科 大貫 稔, 稲月 文明, 小野重五郎, 久保田 智 ダイナボット RI 研 加藤 貞武, 倉田 邦夫

ACTH の Radiommunoassay の困難性の一つは，優秀な力価の，AGTH 抗体が，確実，かつ大量に作 製出来ない点にある. 我々は, 成熟雄家鬼15羽に，それぞれ市販水性 ACTH 100単位 (Organon) と Freund's Complete Adjuvant との懸濁液を， 3 週間でとに 2 回背部皮下注，その後水性 ACTH (organon) AGTH-Z (organon), 水性 AGTH (Schering) を同椂に, 追加免疫に使用する事によって, 現在検討済の 血清 No. 1 No.10のうち, 塩析法により一万倍の稀积でも, 80\% ACTH 抗体を確認する事に成功し た. AGTH の Radioimmunoassay におけるもう一つの重要な問題は, ${ }^{125} \mathrm{I}$ 又は ${ }^{131} \mathrm{I}$ による標識 AGTH の純度である．ての点については各種ペーパークロマトおよび，カラムクロマトによる分離精製を試みてほ ぼ実用に供しうる状態澾した。更にモルモットからの，第２抗体法による Radioimmunoassay の感度の 改良も検討中である，乙れらの方法により，正常人，肺癌，内分泌疾患における血中 ACTH の測定に関し て検討を加えた。

追 加：徳大産婦人科 礒島 晋三 我々は, HCG 及び LH の radioimmunoassay に anti-body を そのまま polymerize した Immunoadsorbent を用いて，60万至120分で，二抗体法と同じ感度で測定する ことに成功したが，AGTH の如き純粋な抗原を用いるととが出来る場合，HCG や LH の如き純粋でない 抗原を用いる場合より，より効果的に思われるので，試みていただきたいと思う。方法は日内泌誌に投稿中 です.

質 問：京大第二内科 井村 裕夫 (1)免疫抗原として AGTH-Z を使用されたてとはあるか. (2) Immunoassay の溶媒として用いる緩衝液にはウシアルブミンを用いられましたか，それともヒトアルブミン を用いられましたか．私どもはウシアルブミンは AGTH と抗体との反応をある程度抑制するという成績 を得ているので，溶媒にヒトアルブミンを使用されるのが良いと考光る.

応 答: 東京医歯大大淵内科 大貴 稔 主として牛血清アルブミンを使用している. 人血清アルブミ ンについては今後検討していきたい。

98. Charcoal 法による LH の Radioimmunoassay

千葉大産婦人科 御園生 雄三, 関 光倫, O吉原 暉文, 関 克義

LH の Radioimmunoossay の Bound とFree を分離する手段として Dextran coated charcoal を 用いる方法を検討した。抗血清は家鬼抗 HCG 血清を用い, HCG 12000IU/mg に Hunter Greenwood 法に準じ ${ }^{125}$ を 標識しれ. Dextran-coated charcoal は 5\% charcoal 懸濁水と $0.5 \%$ Dextran 溶液を等 
量に混し Stock solution とした. $0.1 \mathrm{ml}$ 抗血清, $0.2 \mathrm{ml}$ Standard, 次いで $0.1 \mathrm{ml}{ }^{125} \mathrm{I}-\mathrm{HCG} 125 \mu \mathrm{g}$ を加 え incubate し, Dextran coated charcoal を加え分離する System を検討した. Dextran 分子量 80,000, 150,000, 250,000 coated charcoal 3ml を用い 0.5\% BSA solution 稀积 Standard curve をかくと分子量 の大きい程分離がよい，又 Standard curve の勾配は抗血清稀釉度により異り，1/500と1/5000とは全く逆 の傾斜となつた，次に尿中 LH 測定のため小览尿稀釈 Standard cunve を求めたとてろ, control との差 を認め得なかつた．Stock solution の液量及び濃度を検討した結果，Dextran $250 て ゙ ， 2 〜 4$ 倍稀瀵 stock solution $2 \mathrm{ml}$ を使うのが適当で Dextran 80 では $2 \sim 8$ 倍稀釈 stock solution $1 \mathrm{ml}$ で, ての場合 Dextran $2501 \mathrm{ml}(1 / 2)$ と平行する Standard curve がえられた。抗血清と Sample にて 1st-Incubation 及び ${ }^{125}$ I-HCG を入れた後の 2nd Incubation 時間の検討を Dextran 250 coated charcoal $1 \mathrm{ml}(1 / 2)$ ，抗血清 1/10000の条件にて行なつた。1st Incubation，0 時間，2nd Incubation 30分〜 1 時間でも測定值を求める ことは可能であるが，12時間以上. 1st Incubation を行なうとより感度が上る. 2nd Incubation は24時間 以内で Standard に変化を来たさない，添加小児尿を稀釈して用いた場合， standard curve の勾配は大と なる，從つて稀秎小児尿を用いた測定值は原尿によるものより高めに出る．検体について二抗体法と比較測 定を行なつた結果，Dextran 250 coated charcoal $1 \mathrm{ml}(1 / 2)$ を用い，原尿添加 Standard 亿依る值と二 抗体法による值は略々一致し， 2 倍稀橎尿添加による值は高めに出た。しかし勿ら両測定值は平行性を保つ ている. 以上尿中 LH の Dextran coated charcoal 法による測定に関し, 種々の検討を加えその実用に供 し得るととを示した。この方法は簡易及び短時内測定等の利点がある.

追 加：阪大産婦人科 三井 磐 私どもも Radioimmunoassay の簡易迅速測定法を試みたので追加 したい. 家鬼に調製した抗 HCG 抗体を小児尿蛋白で吸収した後, $\gamma$-globulin を硫安塩析法で分離, 乙れ をホルマリン化タンニン酸処理ヒツジ血球に感作せしめ, solid phase とした。本法に従えば, 2 時間の incubation で允分であり，また $10 \mathrm{mIU} \sim 100 \mathrm{mIU} / \mathrm{ml}$ の間に直線関係のある標準曲線が得られた $(\lambda<0.1)$. 同一試料にわける二重抗体法測定値と本法による測定值との間には, 良好な相関が得られた $(\gamma=0.98, N=17)$.

99. Radioimmunoassay による尿中 LH の経時的変動

千葉大産婦人科 御園生 雄三, 関 光倫, ○吉原 睴文, 関 克義

尿中 LH 動態を知るために Radioimmunoassay（RIA）を用いて24時間の尿中 LH の定量を行なつた。 RIA は抗 HCG 血清の LH との交叉反応を利用した二抗体法を採用し, 2nd IRP-HMG を standard と した。検体は 2 時間毎に，或いは $10 \mathrm{ml}$ 又は $20 \mathrm{ml}$ づつ連続 24 時間採取した尿で，その $0.2 \mathrm{ml}$ をIA に 併した。対象は正常月経周期婦人, 子宮筋腫患者, 片側卵巣囊腫剔出患者及び不妊症患者の 9 名, 15 日分で ある. 測定結果 : 26 才正常周期婦人月経時及び月経後の 2 時間単位でみた変動は 5 回の測定でいずれも排泄 型は題似して，LH ピークは月経初期では午前〉午後, 月経後期及び終了後では午前く午後となつた。他の 21才及び35才の正常周期婦人，低温相に於いても同様の排泄傾向をみたが，35才の場合，前二者に比し LH level はたかい. 43才子宮筋腫患者尿についても午前と午後にピークを持つた排泄型を示す。 23 才の無月経 患者では早期に一つのピークが認められた。 26才, 卵巣囊腫剔出前, 後に於いて 2 時間変動は同一のピーク, 排泄型を示した，上上時間的変動は少数例で明確な事はいえず又個人差があるが，総体的にみて 8 時前後，

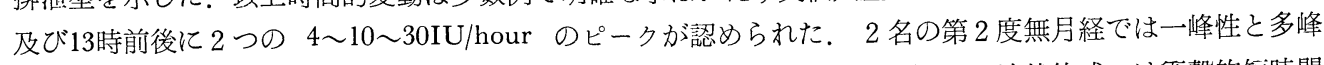

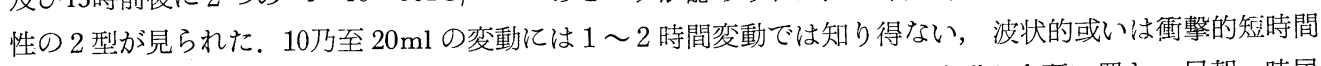
内の変動が認められる．故に尿中 LH の測定値を求める場合には，斯かる変動を念頭に置き，早朝一時尿 中 LH を以つて 24 時間尿中 LH を代表し得るか，今後なお検討を要する。1968年 Saxena は4 時間間隔 の男子血漿中 LH 変動の研究で, 午前にピークを報告し, Midgley も男子の 1 時間毎の血清 LH 変動に関 して余り変化がないというが，女子では 1 日 4 回採血で 7 〜時に他より高濃度を認めている. 今回の尿中 LH 排泄ピークも乙の血清中濃度を反映しているものと思われる. 尿中 LH について連続的に $10 \sim 20 \mathrm{ml} の$ 変化まで調べた報告はなく，LH 動態の一端がうかがわれたものと考える.

質 間 : 北大真下内科 瀬田石智敏 LH の血中の半減期はかなり長いものであるので, 尿中 LH が経 
時的に極端に上下するのは下垂体からの分泌のみでは説明できないと思う, 腎機能とは関係（たとえば尿ク レアチン值の関係など）をしらべてみたか.

応 答: 千葉大産婦人科 吉原 睴文 (1)衝撃的濃淡変動飞関しては血中 LH 濃度を同時に 測定してい ないので，腎機能によるものか，下垂体分泌そのものによるものか何ともいえない。

質問：阪大産婦人科 谷沢修 (1)同一の尿試料における測定值のバラッキはどの程度か. すなわち 測定值の差を有意差として識別しうる限界はどの位とされているか.

応答: 千葉大产婦人科 吉原 暉文 (1)同一症例は同時に測定しているので同一症例を何回にも分けて 測定した時の誤差は避けられる。(2)同一検体を何回かに分けて測つた場合の測定法の変動に関して統計的に 未だまとめていない.

応答: 千葉大産婦人科 関 光倫 (1)今年の日本産婦人科学会総会に於いて 70 検体に就いて我々の RIA 值と DAAD 值が良く相関する事を示した。乙れ机相当長期に渉り，数回に分けて定量したものである.

100. Radioimmunoassay による尿中 Luteinizing hormone の測定

名大産婦人科 石塚 直隆, 反田 豊, 成田 収, 青木 孝允, 水谷 栄彦
三輪 忠人

Radioimmunoassay の最近にわける進歩は下垂体性 Gonadotropin 及び HCG の測定においても画期 的な結果をもたらした。我々は早くからての方法の重要性に注目し，尿中 Gonadotropin を測定する際に， Free 型と Bound 型をアルコール分画法にて簡単かつ充分に分離する方法を用い，その臨床応用を計つて 来た。正常月経周期婦人 6 例の尿中 LH を測定したところ，排卵期の最大 peak は $196.8 \mathrm{IU} / \mathrm{day}$ を示し, ほぼ一峰性の分泌パターンを示した。 又との中の一例について，同一検体で FSH をも測定したとてろ，LH 及び FSH 両者の最大 peak を示す日は月経周期第12日目で全く一致していた。原発性無月経婦人の LH は正常月経周期婦人に比して比較的高い值を示す人ときわめて低い值を示す人があることがわかつた．土勢 婦人では，年令その他の要因も関係すると思われるが，去勢後，時を経るにつれて LH は上昇する傾向を認 めた，又閉経婦人においては，比較的高くかつ変動の少い分泌がある様に思われた．FSH については去勢 婦人及び閉経婦人ともにかなり高い值の分泌があつた。次排卵誘発剤 F6066 及び clomid を各種排卵障 害婦人及び去勢婦人に投与した場合, 薬剤が直接間脳下垂体系に作用した結果と思われる LH 分泌の上昇 (1st peak)が薬剤投与開始後平均 6,9 日目に認められた。薬剤投与開始後平均 14,5 日目，すなわち排卵の ころに第 2 のH peak 老認めた。各種 steroid 投与時のLH変動については, estrogen 及び estrogen と gestagen の合剤投与の場合はともに Suppression の傾向を認めたが, gestagen 及び testosterone 投 与の場合にはともに一定の傾向をつかめなかつた。

質 問：徳大産婦人科 礒島 晋三 (1) LH peak は luteal phase に見られるケースがあつたか. (2) BBT からみて，LH peak が排卵日以後に出現したケースはあるか. (3) エストロゲン，プロゲステロ ン合剂による経口避妊薬投与後の第 1 周期では，LH のピークが殆んど出現し又, 基礎水準の低下も見られ ないデータを我々は得ているが演者の場合はどうか.

応 答: 名大産婦人科 水谷 栄彦 (1) Anorlar 投与例は, 第一周期のものではない. (2) 症例によつ ては黄体期にやや低い peak を認める場合もある。

質 問：神大産婦人科 望月 真人 $\mathrm{LH}$ と FSH を radioimmunoassay で測定し同じ部位にそれぞれ の peak が出現する場合それは使用した labeld protein の中の他の protein Contamination の閭題を考 えるべきか, 或は TSH, LH, FSH などの glycoprotein 系泣共通抗原があるという Rosen や Spierce らの説を考えるべきか，ての様な Contamination 或は共通抗原といつた事柄に関して，もし明解な解答が あれば御教示していただきたい。

応 答: 名大産婦人科 水谷 栄彦 TSH 及び FSH は大量で LH の測定系に影響を与えるが実際 LH の測定にあたつては問題にならない.

質 問: 群大産婦人科 玉田 太朗 (1) LH の peak が 150 200IU のようで, 先程の千葉大学の発表 第 45 巻 第 4 号 
などにくらべ，かなり高いようにと思われるが，てれは，抗原などの差によるものか，あるいは alcoholprecipitation といら操作によるものか. (2) FSH の peak が LH の peak と非常によく平行しているが, LH の contamination あるいは共通抗原の問題は無視できるか.

応答: 名大産婦人科 青木 孝允 アルコール分画法によつて LH 值が特に二抗体法に比して高く出 るとは考えない。事実低い值は低く出るしその点については生物学的にも比較検討している. Standard と して使用している FSH は LH を若下含有しているがての測定系で実際に FSH を測定する場合に他の蛋 白ホルモンとの間の交叉については充分検討しており殆んど問題にならない.

応答: 名大産婦人科 水谷 栄彦 1) 主としてアルコール分画法のデーターをもつているので 2 抗体 法との比較は充分ではない，2）標識に使用した HCG 注生物活性 $1300 \mathrm{IU} / \mathrm{mg}$ である. 3) 我々の使用 した FSH は少量の LH 活性を有する。

追加応答: 千葉大 関 光倫 我々の経時変動の $\mathrm{LH}$ 量は 2 時間值であるので名大の 1 日量より少く出る のは当然である, 但し 1 日量を極く少量に分けて定量し尿量を掛け 1 日量として合計する場合は 1 日尿の一 部分を取り LH を定量しそれに 1 日尿量を掛けた場合より大きい值になる。我々の第 2 回 $\mathrm{F} 6066$ 研究会で 発表した様に排卵時 Peak の LH の 1 日量は 2 抗体法でも名大の発表の如く 100〜200IU だつた。

質 問: 東京医歯大産婦人科 熊坂 高弘 先生の Deta で非 Steroid 系の Clomiphen やF 6066 等を 投与した場合に原発性，続発性無月経では，尿中 LH は投与に上昇する 1 st Peak と，投与後に上昇する 2nd Peak が見られ，又更年期婦人に投与した場合には 2nd Peak が見られないというととはとれらの非 Steroid 排卵誘発剂の作用機序に関係すると思われ大変興味ある現象と思われるが，乙の作用機序と尿中 LH の排泄パターンとの関係についてお伺いし度い.

101. ラットLH の Radioimmunoassay に関する研究 阪大産婦人科 深田 信之, 足高 善雄, 谷沢 修, 松尾健, 三井 褩
三宅 㑆

羊とラット LH 間の免疫学的交叉反応を用いてラット下垂体・血中 LH の測定を目的とし， 2 重抗体法 による Radioimmunoassay (RIA) の方法及び LH 特異性につき検討を行ない以下の様な結果を得た。抗 原として羊 LH を用いて抗血清た調製し，ゲル内沈降反応及び生物学的活性の中和等により羊とラット LH 間に交叉反応のあるてとを確かめた。ヒツシ LH を Agar gel electrophoresis を用いて精製後, 生物学的 活性の最も高い抽出蛋白に ${ }^{125} \mathrm{I}$ を標識し, Polyacrylamide gel DISG 電気泳動法, Radioimmunoelectrophoresis を用いて精製の程度を確かめた。第 1 抗体に抗ヒツジ LH モルモット㑑清 $1: 10,000$, 第 2 抗体に 抗モルモットケグロブリン1：80を使用し RIA 系を設定し，NIH-LH で $\operatorname{lng} \sim 1 \mu \mathrm{g}$ の感度を得， NIH-FSH ではこれに Contaminateしている LH 含有量に一致した Standard curve が得られ LH に特異性の高い ことを確かめた，又羊 LH とラット下垂体抽出物による Standard curve がほぼ平行するととにより，と の系を用いてラットLH の測定の可能なととが判つた，次いで Hohlweg 現象時における下垂体中LH の 変動を Bioassay (BA) 及び RIA で経時的に見ると。注射後 8 時間で下重体中 LH は減少し，それに一 致した血中 LH のピークが RIA によつて得られた。 その他種々な条件下でのラット LH を BA 及び RIA で測定し $\gamma=0.79(\mathrm{~N}=18)$ の高い相関を得た。，以上の事より羊 LH を用いた RIA は BA 亿比し 操作が簡易で，感度も高いので，ラット LH の測定佂有用な手段となりうるものと考光る。

質 問: 群大産婦人科 五十嵐正雄 非常にきれいな deta をありがとうでざいました。 羊 LH でモル モットと家鬼を免疫しておられるが，モルモットと家鬼で抗体産生度に相異が認められたか，スライドには モルモット血清のみを使用した成績を発表しておられるが, 家鬼血清の使用成績を発表されなかった理由を お教气下さい.

応 答: 阪大産婦人科 深田 信之 (1) Guinea pig で調製した抗血清では $1 \mathrm{ml}$ 当り $320 \mu \mathrm{g}$ の NIHLH S8 を中和している，Rabbit 亿おいてもほぼ同程度であつた。 (2) 2 重抗体法を使用する場合，第 2 抗 体の抗血清は第 1 抗体に比べてかなり大量に必要とするので, 第 1 抗体に Guinea pig を使用し，より抗 
血清を得やすい Rabbit を第 2 抗体に使用した。ただ Guinea pig は Rabbit に比し minor component に対する抗体生が弱いような印象をうけるというとともひとつの理由である。

102. プロラクチンの Radioimmunoassay（第 3 報）

農林省畜産試験場生理部第一研 上家 哲

二抗体法による牛プロクラチン (PL) の radioimmunoassay (RIA) により泌乳期の牛および山羊の血 漿中 PL の変動要因を追究した。 この方法で $3 \mathrm{~m} \mu \mathrm{g} / \mathrm{ml}$ 以上の血漿中 PL の測定が可能でプール血漿を同 じ assay および異なる assay で12回測定を繰り返した場合の変動係数はそれぞれ7\%および15\%であつた。 この測定系で牛下垂体抽出物わよび牛血漿中の反応物質は精製牛 PL (NIH-P-B2) と同じ反応を示した山羊 下垂体抽出物および山羊血漿中の反応物質は精製羊 PL と同じ反応を示した。馬，豚，ラット，ニワトリ の下垂体では $1: 10$ 稀釈でも B\%の変化を認めなかつた。搾乳時に得た内因性の牛血墏 PL と精製牛 PL 静 眽注射15分後に得た外因性の牛血漿 PL を Sephadex G-200 カラムでゲル沪過すると，ほとんぞの反応物 質は，血漿蛋白質溶出後 1 つの peak として溶出され両者のパターンは同じで遊離の状態で存在すると考光 られる．血墏 PL の免疫化学的反応性は $-20^{\circ} \mathrm{C} て ゙ 6$ ケ月以上保存しても変らない．動物血液はすべて実験 $1 \sim 1.5$ 時間前に装着したポリエチレンカテーテルから採取した。牛 PL を頸静脈に注射後血漿中のPL は

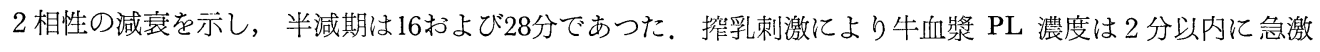
に増加し控乳終了前後搾乳開始（5〜15分後）にピークを示しその後急速に低下する. 泌乳初期（分婏後 15２8日）の乳牛 6 例の搾乳前血漿 PL の最低值の平均は $18.5 \mathrm{~m} \mu \mathrm{g} / \mathrm{ml}$, 搾乳後のピークの平均值は 120 $\mathrm{m} \mu \mathrm{g} / \mathrm{ml}$ であつたが, 泌乳中期（分娩後 104〜 134日, 1 日 2 回搾乳）の同じ乳牛 4 例のそれぞれの平均值は $3.5 \mathrm{~m} \mu \mathrm{g} / \mathrm{ml}$ および $43 \mathrm{~m} \mu \mathrm{g} / \mathrm{ml}$ 亿低下した。泌乳開始後 $1.5 \sim 2.5$ ケ月 1 日 1 回搾乳の山羊 3 例の搾乳開始直

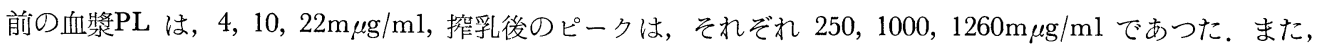
牛および山羊で濃厚飼料給与, 温水による乳房の洗い, 疑似控乳によつて血中 PL 濃度の上昇する例があ つた。搾乳または哺乳刺激は泌乳期のPL 分泌を支配するもつとも重要な因子と考えられる。カテーテル 装着直後の血漿 PL は着後 $30 \sim 60$ 分の值よりも高く，また，採血針を皮下にさす（痛み），連続的放血 $(100 \mathrm{ml})$ 等のストレス性の刺激によつても一過性のPL 濃度の上昇がみられた。

質 問 : 東大中尾内科 斉藤 寿一 頸静脈血中の成績を見せていただいたが, 未端動脈, 静脈血中の溽 度を併せ測定されたととがありましたら御教示いただきたい。

質 問: 京大第二内科 井村 裕夫 (1)内因性および外因性 prolactin のゲル沪過の成績で, 蛋白分画 に一致して見られた分画は蛋白と結合したものとお考旮か.(2)運動は prolactin 值に影響するか.

応 答：農林省畜産試験場生理部第一研 上家 哲 1）1例を除き全部頸静脈血のプロラクチン濃度 を測定した。 その1例では乳静脈血中プロラクチンは, 頸静脈血中プロラクチン濃度よりも低い傾向がみら れた，ての点はさらに，今後追究する予定である，2）プロラクチンは溶液中で涷結融解その他の原因で容 易にポりマーを形成し易いので一応ポリマトライス法ものと考えている，大部分が遊離の状態で存在するが， この小部分がマクログロブリンその他の血清蛋白質と結合しているかどうか不明である。

103. 欠 演

104. Angiotensin の Radioimmunoassay そついての再検討

東北大鳥飼内科 福地 総冕, 三浦 幸雄, 勝島 一郎

われわれはすでに昨年 angiotensin の radioimmunoassay そついて発表したが，今回は angiotensinの の抽出法を検討し, その臨床的応用を試みたので発表する。抗体は val-5-angiotensin II と porcine $\gamma$ globulin との copolymer を，3ケ月以上ウサギに投与して作製した。 radioiodination は Hanter \& Greenwood の方法に準じて行ない, Amberlite GG-400 column で純化した. free と bound ${ }^{131} \mathrm{I}$ angiotensin の分離は dextran-coated charcoal によつて行なつた。測定值は標準 val-5-angiotensin II の示す 值と比較することによつて計算した。本法の感度は $50 \rho \mathrm{g}$ であつた。血液中の angiotensin 抽出法として は Kieselgel, silicic acid, Florisil, Fuller’s earth および SE-Sephadex のほかに, Amberlite CG-400 
column および Dowex-50 column も検討した，てのうち SE-Sephadex が最もすぐれた成績を示し，回 収率は平均 $55 \%$ \%であつた. Amberlite GG-400 および Dowex-50 column がこれにつぐ成績を示した. つ ぎに renin 活性測定に用いた sample の bioassay による測定值と本法による測定值とを比較した。 その 結果，ほほ平行した関係が認められたが， bioassay による測定值は本法による測定值の約10倍の值を示し た。この差を来たす原因としては bioassay 亿用いた sample 中の angiotension が angiotensin I であつ て，ாではないととを推定する成績がえられた。従つて renin 活性測定に本法を用いる際にはさらに検討 が必要である。また抗体と ileu-5-angiotensin II との結合は val-5-angiotensin II との結合に比して弱く， 従つて正確な測定値を出すためには, standard として ileu-5-angiotensin II を用いるか, または standard として val-5-angiotensin II を用いた場合には補正する必要がある. 本法による動脈血中 angiotensin 含 量の正常值は 18-96 $\rho \mathrm{g} / \mathrm{ml}$, 腎血管性高血圧症および Addison 病では高値を，Cushing 症候群と原発性ア ルドステロン症とでは低值を示した。

質問：日大大島内科 小田 立男 (1)先生の講演中で, Dowex-50 で Angiotensin を吸着溶出した場 合を使用した場合の回収率は, 蒸溜水を使用した場合のものと比してどうであつたか, もう一度簡単に御知 らせ下さい. (2)従来の Bioassay の場合のラット昇圧の standard とする Angiotensin を, 現在どてでも Ang II を使用しているが, Ang I を standard としてやる場合の可否又は可能性に就ておききしたい. (3) Ang I は Ang II に比してラット昇圧性はどの位の比率か>.

応答：東北大鳥飼内科 福地 総逸 1) Dowex-50 column を用いて angiotensin を抽出した場合の 回収率は，SE-Sephadex を用いた場合と殆んど同じ（55\%）であつた，2）私の実験結果から，bioassay による測定に standard として angiotensin I を用いた方が， angiotensin II を用いるよりも，正確な測 定值をうるととが出来ると考える。しかし, bioassay 中の angiotensin I はラットの血中に含まれる converting enzyme によつて angiotensin II となつて昇圧活性を呈するのであるから, bioassay の測定法と しては問題がない. 3) angiotensin I の昇圧活性は angiotensin II の1/2〜2/3といわれている.

105. 間脳，下垂体，性腺系における蛋白質核酸合成について（第 1 報）

Hohlweg 効果

阪大産婦人科 尾崎 公已, 會智 敬一, 足高 善雄 Hohlweg 効果に際して, 投与した大量の estrogen が, 間脳部に positive feedback をかけ, 恐らくは polypeptide と思われる GRF を下垂体に移行させ，下垂体の gonadotropin (G) を放出する機構が介在 すると思われる，乙の際 GRF 又はGの合成を伴うならば， RNA および蛋白質合成に何らかの変動を与 えると考えられる. 放出されたGが卵巣に働く際に誘導される蛋白質合成と estrogen の子宮に対する直接 作用をあわせて検討する意味で, Hohlweg 効果に伴う間脳, 下垂体, 卵栄, 子宮での蛋白質, 核酸合成の 変動を検討した。 未成熟雌ラットに estradiol-17 $\beta \quad 100 \mu \mathrm{g}$ を尾注, 一定時間後にそれぞれ ${ }^{14} \mathrm{C}$-valine (蛋 白), ${ }^{3} \mathrm{H}$-uridine (RNA), ${ }^{3} \mathrm{H}$-thymidine (DNA) を投与し, 蛋白, RNA については 1 時間後, DNA に 関しては 3 時間後に諸臟器を剔出, TCA 処理を行なつて radioactivity を計測した. estrogen 投与後, 間 脳では 6 および14時間後に RNA 合成が僅かに促進され，6〜8時間で蛋白合成のやや大きな山がみられ た。乙の時期は間脳部で MAD 活性の変動, G-release の起るとされる時期と一致する.下垂体では Grelease の起る 6〜8 時間にかけては，RNA，蛋白共に合成促進は認められず，乙の放出はプールされたG によるものと思われる。卵巣では16〜18時間後に蛋白合成の促進がみられるが，てれは 6 ～8時間で放出さ れたGの効果と推定される, 子宮では estrogen 投与直後より蛋白質, RNA 合成共に盛んとなり18２4時 間後に最高に達した。乙れは投与した estrogen の直接効果と考えられる。DNA 合成は, 間脳, 卵巣では 変動がみよれず，子宮では18〜24時間後に著明な合成促進が認められた。

106. ラット視床下部及び下垂体後葉性 CRF 活性の日内変動

北大第一生理 広重 力, 坂倉 宗樹, 伊藤 真次

下垂体一副腎系が典型的な日内リズムを示すととはよく知られているが，CRF レベルでは日内リズムの 
存否についてはまだあきらかでない，ての点をあきらかにするために Wistar 系の雄ラットを用いて実験を 行なつた。実験期間は 12 月 1 日の冬季に行ない，ラットの飼育条件としては $20^{\circ} \mathrm{C} の$ 恒温室で人工及び自然光 によつて午前 6 時から午後 7 時までを照射時間とした。予め 1 週間にわたりラットを mannal handling 亿 慣らしたのち 4 匹ずつを断頭屠殺し血中コルチコステロンレベルと共に, 正中隆起及び下垂体後葉中の CRF 活性を測定した。 GRF 活性の測定は我々のラット下垂体前葉組織内直接微量注入法を用いた，その結果正 中隆起及び下垂体後葉内の $\mathrm{CRF}$ 活性は共に著明な日内変動を示すてとが分つた。 そのピークは午後 6 時に, 最低值は午前 4 時から 8 時にかけて存在する。乙の CRF の変動は血中コルチコステロンの変動によく類似 しているが, 前者は常に後者に先行している点は注目に值する。乙のととは GRF 活性の変動が血中コルチ コステロンレベルの変動の原因となつているととを示唆する, 一方未梢血中のコルチコステロンレベルが negative feedback として AGTH の分必を調節するととがしられているため, CRF の日内変動にもこの 因子の関与する可能性が考えられる。しかし副腎摘除ラットでもほぼ同様な正中隆起性 GRF の活性の日内 リズムを証明しえた。 てのととは GRF 活性の日内リズムの generator が, 血中コルテコステロンレベル による negative feedback 機序とは一柋独立して, 中枢神経内のいわゆる bioclockにあるととを物語つて いるものといえる.

質問: 岡大精神経科 高坂 睦年 ての実験を通して, 用いられた Chlorpromazine の作用と影響に ついて, どの様に扔考旮か。

応 答: 北大第一生理 坂倉 宗樹 我々の実験では CRF 活性の検定に影響しない. Injection 後 4 時 間にて体重100 g そつき $1 \mathrm{mg}$ を使用しているから。(ネンブタールと併用)

質 質：神大第二内科 恢古田雅弘 視床下部 GRF 活性と AGTH レベルとの上昇の間に解離のみら れる条件があるか. 例气ば ACTH が増量している時に GRF 活性が低いという条件があるか.

忍 答: 北大第一生理 坂倉 宗樹 正中陸起における GRF 活性のターンオーバーを知る方法が今の所 ないので現在の所はつきり言えない，今後良い方法を考えてての点を検討しようと思つている。

質問：神戸大第二内科 上月 祥生 1) ストレスに対する反応性に日内変動が認められるが，それを 規定する因子として，どのようなものを考えておられるか，2) Pituitary island rat を使つた笑験等によ り, Ether stress の ACTH 分泌に及ぼす経路については, 報告されているが, 他の異なつた種類の刺激に 対しても，同様の反応性の日内変動が認められたかどうか.

応 答: 北大第一生理 坂倉 宗樹 1 ) 我々の microinjection 法の maximam response は 50〜60 $\mu \mathrm{g} /$ d1 であるので assay 方法によるとは考えられない. adrex により cpd B を取りのでき行なつた. 実は行 なつていないのではつきりとは言光ないが cpd B の関係も有るかも知れない，今後追究する予定である。

2) Stress は Ether exposion 1 分間, Loparotory 1 分間の混合 stress のみで他の stress は検討していな い.

質問, 追加：岡大第三内科 高原 二郎 Stress 時の GRF 活性の変動を犬門脈血中より in vivo 及び in vitro Bioassay で認めたので追加させていただく，質問 (1)後葉の GRF が生理的に活動する時はぞ んな時か (Stress 時か, feedback 時か diurnal variation 時か) お教え願いたい. (2)後葉性 CRF 活性は Dexamethasone で block されるがぞうか，お教え願いたい，

応 答: 北大第一生理 坂倉 宗樹 1) 今回は出さないが, 正中隆起と平行した日内リズムが後葉の CRF 活性に見られる。文後葉 CRF 活性はStress 時にも Response をする場合, しない場合有り。後葉 の CRF 活性が生理的に活動する時に関しては今後検討する予定である，2）Stressにより異なるが，抑制 乙得ると思う。

107. In vitro 法による ACTH 分泌機序に関する研究

神大第二内科 辻 昇三, 安井 博和, 老粐 宗忠, 上月 祥生, 谷口 洋
高見 好信, 玉川 公敏, 宮田 昌明, 東 宗則, 中井 裕
伊藤 節子


Spontaneous ACTH release とストレスとしての Lysine-8-Vasopressin（以下 L-8-V と略す）に対す る反応性の二面からの解析を通じて ACTH 分泌機序を下垂体レベルで解明する為に, 白鼠下垂体 4 halves を $95 \% \mathrm{O}_{2}, 5 \% \mathrm{CO}_{2}$ で飽和した諸種の medium 2c.c. 中に置き $37^{\circ} \mathrm{C} て ゙$ medium を30分毎に交換する連続 incubation を行ない， medium 中に放出された AGTH 活性を牛副腎皮貎簿片を使用する in vitro AGTH bioassay 法にて, 又 incubation 前後の下垂体内 RNA, DNA を各々 Schmidt-ThannhauserSchneider 法，インドール反応によるデオキシペントースの発色によつて測定した，KRBG を medium として 5 時間にわたる incubation を行なうと下垂体の AGTH 放出は incubation 直後より徐々に低下し， 2 時間目に最小となり，その後ほぼそれに近い值を持続した。 てのパターンは下垂体内 RNA/DNA 比と約 1 時間の lag time で相関した. glucose-free medium はこの basal な放出パターンに影響を及ぼさなか つた. actinomycin D $10 \mu \mathrm{g}$ を最初の medium に添加するとその medium 内への ACTH 放出は抑制さ れたが，その後の放出パターンは basal なレベルと同じであり, puromycin $50 \mu \mathrm{g}$ の場合は 2 時間目以後 の ACTH 放出が basal なレベルより抑制された. L-8-V 60mU に対して下垂体は preincubation の回 数と無関係に十分反応を示した. actinomycin D $10 \mu \mathrm{g}$ 又は puromycin $50 \mu \mathrm{g}$ で前処置後の L-8-V $60 \mathrm{mU}$ 亿対する反応性も良好であつた。，又 L-8-V の作用時間が30分でも120分でも反応は等しかつたが，5分間 では反応がみられなかつた。 以上の結果より下垂体からの AGTH 分泌は先ず放出がおてり，てれを引金 として蛋白合成機転が始動し AGTH が合成され，てれらの間に平衝が成立すると AGTH 放出は一定と なると考えられた。垂体は AGTH 放出の為の十分な AGTH 予備プールをもつているが，てれは比較 的小さく, ACTH 合成に関与する更に前段階の RNA の比較的大きいプールが存在すると推察された. 又下垂体内と medium 中の AGTH の間にも ACTH 分泌機序に関して feed back 機構が働いていると 思われた。なお L-8-V は煲白合成を介さず ACTH の releaser として働くと考えられた.

質 問: 岡大精神経科 高坂 睦年 以前 Glucose を静眽内に投与すると, 血中 corticoids の上昇を見 るという報告があるが，先生の唯今の結果だと Glucose を medium に入れても ACTH-release に関係な いとのととだが，此の異いは何故とお考えか.

応 答: 神大第二内科 谷口 洋 我々の実験では現在 glucose-free と $200 \mathrm{mg} \%$ glucose の二つの 条件下でのみ検討したので, ACTH の放出が増加するとのデータに関しては詳細なメカニズムはわからな い. 滲当压が関係するのではないかとも考えられるし，インキュベーションの時間も関係するのではなかろ うか.

質 問: 阪大 熊谷 朗 lysin vassopressin によるACTH release in vitro でみてられるが, その場合の下垂体前葉の ACTH 含量は如何でしたか. 追加 : in vitro で lysin vassopressin では下垂 体内の AGTH 合成速度を尣進する作用はなかつた。

応 答：神大第二内科 谷口 洋 下垂体内 ACTH Content はこの実験では行なつていない.

質 問: 北大第一生理 広重 力 (1)1967年に Kraicer が chronic Adrenalectomy 今の ant. pituitesy 中の RNA の変化を追つているが， RNA の contest には変化がなかつたと報告している．生先のも とで Adrenalectomy の効果に対する経験がありましたらお教え下さい.

応 答：神大第二内科 谷口 洋 Adrex をした時の下垂体の DNA, RNA を測定した例数は我々の 処で少例なので，今後検討する予定である.

108.ストレス時における，間垂下垂体副腎皮質系の病態生理について 硅酸吸着法による血中 ACTH の測定

慶大五味内科 五味 二郎, 本間 光夫, 市川 陽一, 吉田幸一郎 硅酸吸着法による血中 AGTH の Radioimmunoassay を行ない， $5 \rho \mathrm{g} / \mathrm{ml}$ の感度を得た。抗体は，ブタ ACTH を牛 $ケ$-グロブリンまたは卵白アルブミンに, Carbodiimide 反応により結合し, モルモットを免疫 して作成，4万倍稀釈で使用した． I ${ }^{125}$ のラベルは Galskov (1966), 精製は Landon (1967) の方法で行 なつた。血漿1〜2 mlに, I ${ }^{125}-\mathrm{ACTH} 12.5 \rho \mathrm{g}$ を加えたのち, 硅酸 $12 \mathrm{mg}$ で吸着, $0.5 \%$ HSA で洗てつたの 
ち, アセトン, 水 $(1 ： 10)$ 亿， $0.01 \mathrm{~N}$ になる様 $\mathrm{Hcl}$ を加光た溶液 $0.4 \mathrm{ml}$ で抽出， $0.2 \mathrm{M}$ ホウ酸緩衝夜, $0.1 \mathrm{~m} 1,0.05 \mathrm{~N} \mathrm{NaOH}$ 一滴を加光, $\mathrm{pH}$ を 8.4 亿したのち, 抗血清と共に, 3 日間インキュベートした。 $\mathrm{B}$ と Fの分離は，タルク吸着法によつた。との抽出法は，Donald の原法に比し，抗原反応が，はるかに少な かつた，標準曲線は，DM 投与後の正常人血漿に，既知量の ACTH を加えて作成した。14の正常人血獎 に種々の量の ACTH を加えて測定し, 実際に得られた值を, 期待值と比較した, 両者の回帰直線は, $\mathrm{Y}=$ $0.976 \mathrm{X}+3.2(\rho \mathrm{g} / \mathrm{ml})$ で, $\mathrm{Y}=\mathrm{X}$ とほぼ一致した。正常人18人の平均は, $8 \mathrm{AM}: 46 \rho \mathrm{g} / \mathrm{ml}, 4 \mathrm{PM}: 28 \rho \mathrm{g} / \mathrm{m} 1$

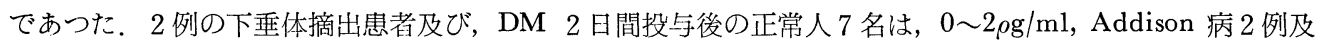
び下垂体性 Cushing 症候群 2 例では, 440 内至 $1000 \mathrm{\rho g} / \mathrm{ml}$ と, 高值を示した。正常人に Piromen $0.5 \mu \mathrm{g} /$ $\mathrm{kg}$ を静注したとてろ， 2 時間後に $250 \rho \mathrm{g} / \mathrm{ml}$ 達した。 正常人 5 名に, インシュリン $0.1 \mathrm{u} / \mathrm{kg}$ 静注したとて ろ， 3 例では 30 分後に， 2 例は 45 分後に最大となり，以後漸减した。最大值の平均は， $475 \rho \mathrm{g} / \mathrm{ml}$ であつた。 HGH は ACTH 亿比し, 約15分遅れて上昇し, 個々の例における最大值も30分前後遅れていた，4時間 にわたる胃切除術においては, ACTH は, $800 \rho \mathrm{g} / \mathrm{ml}$ 亿達するピークを30分及び, 120 分後に示し, HGH は30分後に最高值を示したのち， 3 時間にわたつて軽度の上煍が認められた。

追 加：東北大鳥飼内科出村 博 私共も Silicic acid 吸着法による血墏 ACTH の抽出を行ない radioimmunoassay に応用しているので追加する. Slide 1 は $3 \mathrm{ml}$ 血漿に AGTH を加え種々の量の silicid acid を加えた場合, ACTH の回収率は, silicid acid 150mg を加えたときに平衡に達したととを 示す. Slide 2: そてでこの条件を用いてての slide 亿示した方法で, 血漿 $3 \mathrm{ml}$ よ抽出すると水酢アセ卜 ン水で 2 回溶出した後の回収率は $67.4 \%$ と良好であるが，その後アセトン沈澱法を用いると最終回収率は約 $40 \%$ となる. Slide 3 はこの方法を用いて正常者扔よび諸種疾患患者の午前 8 時の血漿 AGTH 值を測 定した絬果である。正常者10例では38ないし 71 , 平均 $56.9 \rho \mathrm{g} / \mathrm{ml}$ だつた。糖質ステロイド連続投与例およ び下垂体機能低下者では not detectable，右端黒丸で示した副腎皮質過形成による Cushing 症候群では高 值白丸の腺腫, 四角の副腎癌による Cushing 症候群では not detectable だつた。

質問：鳥飼内科出村 博 1) Standard には必ず hypopitutarism の㭧者血墏或いは Dexamethasone 抑制血漿を用いているか不か. 2) acid acetone で溶出後 incubation まで持つて行く方法につい てもう少し詳しくお教え戴きたい.

応 答: 慶大五味内科 市川 陽一 1 ) 硅酸吸着後の方法は, $0.4 \mathrm{ml}$ の $0.01 \mathrm{~N} \mathrm{HCl}$ in acetone, water (10：100) で抽出し，前もつて， $0.2 \mathrm{M}$ ホー酸緩衝液 $\mathrm{pH} .4,0.1 \mathrm{ml}$ と $0.05 \mathrm{~N} \mathrm{NaOH} 1$ 摘を加えておいた, プラスチック試験管に移し，混和，抗体を加えてィンキュベートしている．2）尿中 ACTH 測定の試験は ない。

質 問 : 北大真下内科 瀬田石智敏 われわれは尿中 ACTH を同様の硅酸吸着法 (micro-fine granule of silicic acid-Quso) で行ない, radioimmunoassay 法で測定した。回収率は約60\%であつたが SU4885 投与前後共に not-detectable であつた。演者は尿中 AGTH 測定は試みなかつたか.

109. AGTH の酸による活性化のメカニズムについて

塩野義研 中村 益久, 田中 明

CRF の bioassay を検討している過程で, in vitro でメジウム中に放出された ACTH 活性は, メジウ ムを酸性にするととにより活性が増大した。一方，CRF の標的器官であるラット下垂体前葉には，105,000 $\times \mathrm{g}$ 上清に存在し，容易に抽出されてくる AGTH と，細胞顆粒分画に存在し，氷酶酸，酸性アセトン等で, 抽出されてくる ACTH とが区別された。 ての内，可溶分画の AGTH 活性は，中性でおくと低下し，酸 性にすることにより，可逆的に活性が回復した。乙れを Sephadex G75 のカラムで検討したとてろ，中性 で活性の低下した標品は void volume に溶出し，酸性により活性を回復した標品注， $\alpha$ p (1-39) AGTH が出る位置に溶出した。乙れらの事からラット下垂体前葉組織可溶分画又は， $0.154 \mathrm{M} \mathrm{NaCl}$ 抽出分画中に AGTH と結合し，高分子複合体を形成し，と同時に，その corticoidogenic 活性を mask する成分の存在

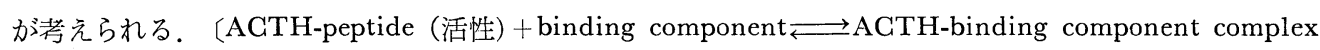


(不活性) ). ACTH 結合成分の藏器分布を見るとラットの副腎, 卵巣, 腎臓, 肝臓にも存在し, $0.154 \mathrm{M}$ $\mathrm{NaCl}$ で抽出され， $4{ }^{\circ} \mathrm{C} ， 24$ 時間の incubation で 50-150 $\mu \mathrm{g}$ の蛋白量で $100 \mathrm{mU}$ の $\alpha \mathrm{p}$ (1-39) ACTH の活性を mask した。乙れらはいづれも，酸性で活性を回復した。ラット腎組織の ACTH-binding component は, 硫安40〜50\%飽和分画にあり, リボヌクレアーゼ処理で失活しない. 同様な incubation 条件 下で, 酵母 RNA, 牛血清アルブミン, 牛 $\mathrm{r}$-グロブリン等は 1-1000 $\mu \mathrm{g}$ の範囲で AGTH 活性に影響を与え なかつた。

質問：京大第二内科 井村 裕夫 (1) ACTH はガラス管壁などの inert surface 亿吸着されやすいの で, 蛋白との結合は特異的なものか，それとも非特異的な吸着かの問題が残ると思う。乙の点について何か, たとえば蛋白を変性させるなどの実験によつてたしかめておられるか. (2) Dasgupta のいう precorticotropin についていかが扔考えか. またUrea の影響を見られたてとはあるか. (3)肝, 算の上清分画には蛋白分 解酵素が存在するので, ACTH は非活性化されると思うが, 酸性にもどした後, 完全な活性の回復は認め られたか.

応答: 塩野義研 中村 益久 (1)ガラス表面への吸着 (stouffer et al. 1963), アルブミンとの相互作 用 (Browar et al. 1955, Stouffer, et al, 1966, Werder, 1968) 等がすでに明かにされているが, 䈣密には イオン交換クロマトグラフィーで分離される物質は, すべて吸着能を持つととになるが，今度の場合，産生 細胞，標的細胞も含めて，その可溶分画に天然存在するという点で，又，ラジオアクティビティーでなく， complex 形成が明らかに，コルチコイド産生能をマスクしてしまうという点で，興味を持つた訳である. ての場合は, binding と生理活性のマスクがパラレルな訳である.ラベルした ACTH ペプチド, ACTH アナロガス等による displacement を調べたいと思つている. (2) Dasgupta は，0.154M NaCl 抽出分画を 低温保存後, 酸, urea 等で活性の上昇を見ている訳で, 私共の中性低温 incubate で complex 形成した 標品注相当すると思う。乙れは，proinsulin と同じような意味で precoursor と呼ぶてとはできないと思う。 これとは別に, 共有結合でつながつた pro-corticotropin の存在の可能性は考えていいと思う。私共では, urea は見ていない，(3)副腎, 肺, 腎, 肝, 等の上清分画は, 迅やかに常温で ACTH ペプチドを分解し てしまう。下垂体前葉でも peptidase 活性が知られているが, それ程 ACTH を分解しない。乙れらの 分解は $4{ }^{\circ} \mathrm{C}, 24$ 時間 incubate でも若干起り, 下垂体以外の場合では 50〜80\%の recovery が普通である, てれは，まだはつきりしないが，ACTH ペプチドが complex を形成してしまうと醭素分解を受けにくく なる。したがつて酸性での活性回復のレベルは, その上清分画中のACTH-binding 活性と, 蛋白分解活 性のバランスによる. Dose-respone の実駼から, てんな感じをもつている.

質 問：阪大山村内科 熊谷 朗 1 ) 三つの AGTH は, AGTH そのものの異なり（構造など）は ないのではないと思う。酸抽出で取れてくるものは物理的に取れて来るものか. プロコルチコストロピンな ぞと考劣わわて御意見をお聞かせ下さい，2）下垂体前葉 AGTH 濃度として Total としてあらわす場 合は酸抽出でよいか.

応答：塩野義研 中村益久 (1), 下垂体前葉中の ACTH の存在状態についてですが, 日内恋動に ついての多くの報告, 例えば Retine et al の下垂体 AGTH の変動は, 下垂体中の可溶性, AGTH, 全体 の約半分の ACTH 活性を見ているととが，その抽出法からわかる。私共では, dexamethasone 投与, 副腎摘出等で, 可溶性 ACTH（水, 生食等で容易に抽出されるもの, 細胞分画でいえば, $105000 \times \mathrm{g}$ 上清 分画来るもの), 細胞顆粒結合型 AGTH (水醮酸, 酸性アセトン等で水抽出残渣或いは, 細胞顆粒分画か ら抽出される) 等が変動するととを見ている。下垂体 ACTH 含量の変動を見る場合には, どのような抽出 法によつて, どの分画の ACTH を見ているかを明らかにしておくべきだと思つている．ストレス時に下垂 体が放出される ACTHが, 可溶分画からのものか, 顆粒分画のものか, 可溶分画と顆粒分画 AGTH との 平衝関係等については, 未だスペキンーションの域を出ていない, 今後の問題かと思う。(2) [(ACTH). (ACTH-binding component)] complex が下重体前葉組織に，そのまま存在しているかどうかという点は， はつきりしない，最初に述べたように，in vitroで，下垂体切片に GRF を加光て KRBG メジウムに放出 
された ACTH はメジウム中で大部分, ての complex の形で存在していると思われる。酸性にするてと により初めて unmask された ACTH 活性が出てくる.

110. 視床下部性 CRF 活性に及ぼす ACTH 前処置の影響

北大第一生理 広重 力, 佐藤 武慧, 伊藤 真次

下垂体前葉ホルモンの分泌調節に関して最近前葉ホルモン自体による前葉ホルモンの分泌抑制の存在が注 目され internal 又は short feedback と称されている. ACTH の分泌についても主に Halasz らゃ Martini らによつて同様なメカニズムの存在が主張されている。 そてで我々は GRF レベルでの short feedback 機構の介入様式をしるてとを目的として，ACTH 前処置が視床下部性 GRF 活性に及ぼす影響につい て二, 三の実験を行なつた，GRF 活性は我々のラット下垂体前葉組織内微量注入法を用いて測定した。正 常雌ラットに ACTH ar gel (Armour) 8単位を6 日間にわたつて連日皮下注射すると正中隆起部のGRF 活性は著しく抑制された。すでにデキサメサゾン投与がストレスによる CRF 活性の上昇を有効に抑制する ことがしられているため, 上述の効果はあるいは内因性コルチコステロンに胄来するとも考元られる。 そて で予め11日前に両側副腎を摘除した動物について実験を行ない, AGTH ar gel 投与後各々 4 時間, 1 日， 4 日にわたり CRF 活性の resting level 及びェーテル曝露ストレスに対する反応をしらべた。 その結果 AGTH 前処置によつて GRF の resting level はほとんど影響されないが, エーテルストレスに対する反 応は ACTH 投与後 4 時間で著しく増強されることが分つた。 ての増強作用は ACTH 投与後 24 時間では あきらかでなかつた。乙れらの結果の生理的意義については必ずしもあきらかではないが，Sawyer らの主 張する positive feedback との関連において考虑されるべきものと思われる.

質 間 : 京大第二内科 井村 裕夫 何らかの意味での short feedback の存在を示唆さる成績は私ぞも も得ているが，他方では，たとえば Addison 病血中 AGTH の研究などでは, short feedback の存在に 疑問をいだかせる成績も得ている，ステロイドによるfeedback は速やかに作用するが，AGTH による feedback は緩行に㗢くということが考えられるが，そのような成績はお持ちでないか.

111. 血中 ACTH に関する臨床的研究 (第 3 報)

外因性 ACTH の血中 ACTH におよぼす影響

新潟大第一内科 石田 良平，今田 正道，佐々木英夫，鈴木 芳郎，真山 俊 牧野 英二, 松岡 松三

ACTH の short feed back 機構の解明は臨床的意義が大きいと考元られる。血中 ACTH はラット副 腎組織 corticosterone 濃度を指標とする生物学的測定法で測定した。臨床例は毎朝 8 時に血中 ACTH を 測定した副腎摘出ラットでは, control 群の断頭例を除き, すべて urethan 麻酔後 ether stress 時に測定 した。副贅全摘例および Addison 病例に合成 ACTH Z lmg/day を 2 日から 5 日間連日投与し，投与前 後における血中 AGTH の動態を観察した。投与前值に比べ投与後血中 ACTH は 6 例中 1 例を除きすべ て明らかな低下を認めた。更に合成 AGTH Z 投与前後に Lysine-8-Vasopressin test を施行し, 反応值を 比較すると Cushing’s Syndrome でコバルト照射後副腎摘出例を除いて，3例に basal 值の低下がみられ たが，L-8-V による血中 ACTH の反応量では反応 pattern の相違が認められ主として Release の低下 を示唆する成績を得たが，全体の反応量は大差なく， stress 亿対し抑制作用がないるのと考元られた。尚副 算全摘ラットで ACTH 投与群と非投与群とに分け， stress 時の血中 AGTH を比較すると，投与群では 明らかな血中 AGTH の低下を認めた。次ぎに ACTH 投与期間（2 日，3日，7日，21日間）による血 中 ACTH の変動を観察すると, 非摸与群の経時的增加に対して, 投与群では全期間を通じ, stress 時の值 と同程度の值であつた。乙の事実から注目されるととは非投与群では経時的に血中 ACTH の増加がみられ るのに対して，ての投与期間では ACTH 投与群は常に stress level の值を示していたてとである。乙れは ACTH 投与で stress による血中 ACTH の分泌を抑えるてとが出来ず，血中 ACTH の抑制作用は negative feedback を介しておてるものと考元る. 更に CRF活性についても AGTH 投与群は非投与群に比 べ明らかな低下を示唆する成績を得た。以上外因性 ACTH により内因性 ACTH におよぼす影響は明ら 
かであり, ACTH short feedback が存在するものと考朰れる. 尚 AGTH の臨床的使用にさいしては, てれらの事実を充分考慮して使用しなければならない。

質問: 北大第一生理 広重 力 (1) AGTH 投与 VP 亿対する AGTH 放出反応が retarded であ る点は, 以前 Brodish が hypothalamic lesion rat を用いて得た結果とよく類似していて興味深く拝聴し ましたが，乙の間の関係から何かメカニズムについての speculation がありましたら御教え下さい. (2) Brodish の法で GRF をはかられたそうだが，乙の方法では recipient が normal rat であるため，nonspecific な反応が問題となると思うが，その点について。

応答：新潟大第一内科 石田 良平 (1) Cushing’s Synd. で adrenalectomy を行なつた Kranke で ACTH 投与後の L-8-Vasopressin test で遅延反応を示していたのは Cushing’s Synd. そのものの病態と いうものを全く, 否定は出来ないが, 遅延の原因は, 主として release でないかと考えている. (2) Brochisder 等の未梢血中からの CRF activity の測定は, normal animal の使用の段階で stress がかかるととは充分 考觉なければならないので, 検体を注射する前に一応 animal を set した状態で control を置いて行なつた。 質問：阪大山村内科 熊谷 朗 1) Short feedback mechanism についてはどうか。 2) pituitary AGTH content そついてはどうか.

応 答: 新潟大松岡内科 佐々木英夫 Short feedback mechanism については人により解釈が異るよう であり，われわれは一応，視床下部を含めた意味で使用している。 pituitary AGTH の content や変化に ついては直接測定していないが, 現象的に L-8-V test の時の血中 ACTH response pattern から ACTH の主作用点は release の抑例と考えている.

質 問: 京大第二内科 井村 裕夫 Addison’s disease ではどうか.

応 答：新潟大第一内科 石田 良平 addison's disease 飞対しては倹討をしていない.

112. ACTH 分泌系の negative feedback 機序について

北大真下内科 武部 和夫, 国田 晴彦，伊藤 宜人，堀内 淑彦，真下 啓明

Stress 下での ACTH 系分泌に corticoid の feedback 機序が働いているか, 及びその作用部位か問題 とされている。 ラットを用いて stress 下の未梢血中の corticosterone (Cpd. B), 及び正中隆起抽出液中の GRF 活性を指標として dexamethasone（dexa）による抑制効果を経時的に追求した。実験方法：Wister 系雌ラットを用い，午後 0 時 40 分に nembutal t $5 \mathrm{mg} / 100 \mathrm{~g}$ B.W. を注射し，20分後に開腹，30秒間管索 引の stress を加えた. stress 15分後に断頭採血を行ない未梢中の Cpd. B を測定した。 また stress 2 分後 亿断頭し, 正中隆起の切片を $0.01 \mathrm{~N}$ 跡酸生食液に入れ，ホモゲナイズ，遠心を行なつた．その上清 $0.4 \mu 1$ を Yates の下垂体内微量注入法の広重らの変法で下垂体内に注入し CRF 活性を測定した。 stress を加える $1 ， 3 ， 6 ， 12 ， 20$ 時間前に dexa t 25, $250 \mu \mathrm{g} / 100 \mathrm{~g}$ B.W. 在腹腔内に注射した。対照として同時刻に生 食を注射した。結果：stress による血中 Cpd. B, CRF 活性の反応は dexa $25 \mu \mathrm{g} / 100 \mathrm{~g}$ BW t stress の $3 ， 6$ 時間前に投与しておくと有意に抑制された。 dexa $250 \mu \mathrm{g} / 100 \mathrm{~g}$ BW を stress の $1 ， 3 ， 6 ， 12$ 時間 前に投与しておくと有意に抑制された。 $3 ， 6$ 時間前に dexa を投与したときは GRF 活性，血中 Cpd. B の抑制程度は dexa の量住関係なかつた。 また dexa の CRF 活性抑制効果と血中 Cpd. B 抑制効果は同 值であつたととから dexa の作用部位は主に正中隆起又はそれより上位中枢に作用するものと思われる. dexa の ACTH 系分泌抑制にはdexa の一定の量が必要で, それ以上に量を増加せしめても抑制効果は増 強されない. CRF assey そ用いるラットに dexa 50, 200, 1000 $\mathrm{g} / 100 \mathrm{~g}$ BW t投与し, 下垂体に正中隆起

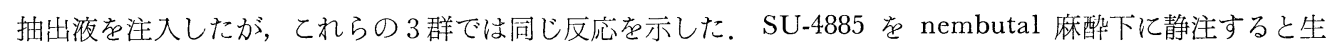
食静注の対照に比して有意に GRF 活性が増加していた。 SU-4885 は正中隆起を介して AGTH 分泌を来 すものと考えられる。

追 加: 北大第一生理 広重 力 Decadron の suppression の site of action は従来 controversial である。しかし我々の CRF assay 法で CRF 活性がひつかかるという事実は major site of action がや はり hypothalamic 又はその上位ラベルにあるといら風に考えるわけである。しかしての問題はやはり流 
動的であつて，たとえば Yates は従来 neural site 説であつたが，でく最近は pituitary site も考虑してい る.しかし Major site は neural site に求めている。

質 問：神戸大第二内科 安井 博和 1) 非常に確的な問題だが， steroids そしろ，ACTH にしろそ の Feedback の作用部位について先生の教えを教示して頂きたい，2) Dexamethasone 投与後， stimules を負荷した場合，AGTH 分泌の反応は完全に抑制されず pastial inhibition のパターンであるが，その場 今残余の反応する部分がなお存在する事の解釈について先生の教えを知らせて頂きたい.

応答：北大第二内科 武部 和夫 1) Laparotomy+intestine traction に対する dexa の suppression は partial です。何故 partial かについては不明だが, Laparatomy のみでは suppression は complete のようです. Yates らのいう stress の種類により異なるかどうか不明である。 2) dexamethasone の suppression の部位は我々のデータからは主役は Hypothalamus あるいは，Hypothalamusより上位と考え られる。 dexa $50 \mu \mathrm{g} / 100 \mathrm{~g}$ B.W. 以下の量では下垂体レベルで suppression が働いているかどうか不明である. 113. ACTH 投与後の下垂体機能について

東京医大内科 梅原 千治，○住谷 亮逸，今井 龍雄，杉本 民雄

$\mathrm{ACTH}$ を連用した時の下垂体機能について検討した，刘象はステロイド非使用群 7 例，ステロイド使用 群 9 例で，之等に合成 $\beta^{1-24}$ corticotropin-Zn を 1 日， $0.5 \mathrm{mg} ， 14$ 日〜 1 ケ月投与し，ACTH の投与前及 び中止後に SU4885 テストを行なつた。他に ACTH 1 日 $1 \mathrm{mg}$ を短期間（2〜3 日）投与した 4 例につい ても同様の検討を加えた。その結果次の成績を得た。(1)ステロイド非使用群の尿中 17OHCS 排泄量は $\mathrm{ACTH}$ 投与前の平均 $5.9 \pm 1.5 \mathrm{mg}$ /日に対し，投与 2 日目以降は前值に対し平均 20〜 38mg/日の増加がみら れた. ステロイド投与群では前值の平均は $1.37 \pm 0.3 \mathrm{mg} /$ 日, $\mathrm{AGTH}$ 投与後 $2 \sim 3$ 日立分増加反応のみら れないものもあつたが，4 日以降は平均26〜 42mg/日の増加を示した. (2) ACTH 投与前と中止後 $3 〜 5$ 日 目の尿中 17OHCS 排泄量はステロイド非使用群では 11-deoxy 及び 11-oxy 分画を含めて有意差はなく, ステロイド使用群で $\mathrm{ACTH}$ 投与中止後全例に平均1.6mg/日の増加がみられた。 (3) AGTH-Zn 1 日 0.5 $\mathrm{mg}$ の連続投与前及び中止後の SU4885 テストの結果, ステロイド非使用群では 1 例で中止後の反応量の低 下がみられその他は全例正常反応を示した，ステロイド使用群では ACTH 投与前の反応で全例低下反応を， 中止後は 30 日間投与例を含む 2 例が正常反応を，1例が低下反応を示した。 (4) AGTH $1 \mathrm{mg}$ を 2 日投 与した 4 例中 3 例は投与前及び中止後に SU4885 に正常反応を，1例は中止後に反応の低下がみられた. 然し 17OHCS 反応量の上で ACTH 投与後全例で多少の減少傾向を示した. 以上の成績から合成 ACTHZn 1 日0.5 mgを 2 週〜 1 ケ月の投与では SU4885 亿対する下垂体の抑制はみられず，乙の程度の使用量で は臨床上問題は少い様に思えた．然し 1 日 $1 \mathrm{mg}$ の短期使用例で SU4885 に対する反店量の低下傾向がみら れた事は下垂体・副腎機能検査の目的で ACTH を投与する際には，原則として SU4885 テストを先行さ せるのが望ましいと考える。

質 問 : 岡大第三内科 高原 二郎 1) 少量の外因性 ACTH の長期連続投与を行なつていると尿中の ステロイドの初期投与時に比軽して減少して来るてとをみているが，先生の所ではそうした事はないか.

2) AGTH を投与すると血中 Cortisol は高值となり視床下部からの GRF 分泌を抑制すると考えられる. そうした状態での SU-4885 投与は少量の ACTH しか分泌されないが副腎皮質が過形成になつているため 一見視床下部下垂体副腎皮質機能が正常と考えられるのではないか.

応 答：東京医大内科 住谷 亮逸 1) 合成 ACTH $0.5 \mathrm{mg}$ 或は H.P AGTH 80単位を使用した範 因内では特に著明な 17OHCS 排泄量の低下傾向は認めていない，2) ACTH 長期投与により副腎の hyperplasion が起りその為に SU4885 投与による少量の ACTH 分泌でも 17OHCS 排泄量の増加を来す可能 性は考えられない事はない。

質 問：阪大西川内科 五十嵐 暢 1) ACTH 投与の期間の最長は何日間か. 2) ACTH 投与後 SU をくり返して投与した例はあるか. 3）ACTH 中止後何日目に SU テストを行なつたか.

応 答: 東京医大内科 住谷 亮逸 1）長期使用例は合成 ACTH 0.5mg を 3 週投与したのが 1 例, 
1 ケ月投与例 1 例であるが 1 ケ月投与例は更に投与継続中である。 2) AGTH 投与中止後に行なう SU4885 テストは 5 日前後に行なつている. 又, その後しばらくおいた後 SU4885 を再投与した例はない.

追 加：阪大山村内科 熊谷 朗 1) 私はネフローゼ症候群の治療に $\beta^{1-24}$ ACTH-Z0.5mg 6 ケ月 連用投与した症例の投与後の下垂体剖菌機能を検討したが，その結果中止後 1 ケ月は尿中 17-OHCS 值は $20 \mathrm{mg}$ /日前後の排泄量の増加が認められ怖らく hypertrophy がその時期までつづくものと思われる，その 時のメトピロンテストは陰性であるが, 前值が高いので下垂体が機能不全あるとは思われない. basal な值 にもどつた時期ではメトピロンテストは正常で，ての点ステロイド療法などと本質的に異なり，その意味で 有利であると思う。

114. Corticosteroids 投与下における薬物の副腎皮質賦活について

名大環境医研 石原一郎, 横尾百合子, 田村 好弘

Pentobarbital 麻酔下で cortisol 50mg 1 時間の点滴静注を行なつても, 犬の視床下部基底内側部のある 一定部位を電気刺激してひき起される副腎静脈 11-OHCS output の増加は殆んぞ抑えるてとが出来ないて とは既に報告した。乙の部位は corticoids 投与下で電気刺激のみでなく液性因子に対しても賦活され得る と考え, 中枢刺激作用を有する 2,3 の薬物を用いて検討した。実験は前日に副腎静脈へ採血用のカニュー レを装着した犬を用い，失血の影響を避けるためにリンゲル液の点滴を行ないながら pentobarbital 麻酷下 で採血し, 副腎静脈 11-OHCS output の変動を観察する方法で行なつた. Meclofenoxate hydrochloride $20 \mathrm{mg}$ および $50 \mathrm{mg} / \mathrm{kg}$ の静注では 11-OHCS output の著明な持続する增加を認めたが, cortisol 50mg 点 滴投与後には薬物投与後の一過性の著明な増加のみが認められた。 Pyrithioxin $30 \mathrm{mg} / \mathrm{kg}$ 静注では中等度の 増加か洔続する傾向がみられたが， $50 \mathrm{mg} / \mathrm{kg}$ 投与では增加は著明であるが持続は短かつた，cortisol 点滴後 にもこの増加は維持された. cortisol 投与の代りに betamethason $0.3 \mathrm{mg} / \mathrm{kg}$ 点滴を行なつたあとでも Meclofenoxate HCl $30 \mathrm{mg}$ および $50 \mathrm{mg} / \mathrm{kg}$, あるいは Pyrithioxin $30 \mathrm{mg}$ および $50 \mathrm{mg} / \mathrm{kg}$ 静注によつ て 11-OHCS output の増加がみられた. GABA $200 \mathrm{mg} / \mathrm{kg}$ の静注では中等度の強さの持続する11-OHCS output の増加がみられ, cortisol $50 \mathrm{mg}$ 点滴後には薬物投与にひきつづく一過性の増加のみが認められた。 Angiotensin II $1 \mu \mathrm{g} / \mathrm{min}$ の点滴を1時間行なうとその間 11-OHCS output の持続的な增加が起るが, cortisol $50 \mathrm{mg}$ 点滴後には output は非常に低いれべるに抑えられた. Angiotensin II $10 \mu \mathrm{g}$ および $20 \mu \mathrm{g} /$ min の大量を 5 分間投与すると非常に強い output 増加が起り, cortisol $50 \mathrm{mg}$ 点滴後にはこの一過性の増 加はやや低いか明瞭に出現した．以上の結果は視床下部電気刺激の結果と考光合せると，中枢刺激剂のある ものは視床下部の副腎皮質賦活に関与する corticosteroids resistant mechanism をも直接刺激する可能性 をもつととを示唆する。

追 加：弘前大麻酔科 滰口 雅博 GABA 類似物質である $\gamma$-Hydroxybutyrate $(\gamma$-OH) の下垂体副 腎皮質機能へ及ぼす影響を検索した。杂隹成犬及び手術患者に $\gamma-\mathrm{OH}-\mathrm{N}_{2} \mathrm{O}$ 麻醉を行ない, 犬については麻 酔中の副腎静脈血中 17-OHCS 濃度の変動を, 人については血中 ACTH 濃度及び血中 17-OHCS 濃度を 経時的に測定した。その結果, 犬副婜静脈血中 17-OHCS 濃度は麻醉開始後30分に最大ピークを示す増加 を認めた。 また人についてはその1例であるが血中 AGTH 濃度は麻醉導入前, 麻酔開始後 20 分では 1.0 $\mathrm{mu} / 100 \mathrm{ml}$ 以下で nondetectable であつたが，麻䣲開始後40分及び手術開始 30 分でその增加を認め，一方 血中 17-OHCS 溇度は階段的な上昇を認めた。 以上の事より $\gamma$-OH は下垂体前葉を刺激して ACTH を分 泌させ，副腎皮質機能を六進させると考えられる。

質 問: 北大第一生理 広重 力 Median Eminence に Yates がそのモデルの中で主張しているよ うな glucocorticoidresistent な area が確認できるか厑かは, GRF の産生部位との関連からかなり本質 的な問題であらうと思う。 そこで先生のお示しになつた resistant areaは, たとえば弓状核などとの関連 でどのようになつているか.

応 答: 名大環研 田村 好弘 視床下部の組織学的検索は現在までのとてろ霞極部位（刺激部位）の確 認のみ行なつている段階であり, 線維連絡の問題については詳細な検討を行なつていない. 電気刺激による 
反応が cortisol resistant である部位は視床下部基底内側部でもある限られた範囲 (arcuate nucleus, ventro medial n. suprasptic n. など) であつた.

質 問：阪大山村内科 熊谷 朗 Angiotensin 注射で plasma cortisol が上昇するようだが，私共 はラットを使い $100 \mathrm{ng} / 100 \mathrm{~g} \mathrm{BW}$ という大量投与後副腎のアスコルビン酸の減少で検討した結果, 減少率は 少なく, ACTH まわりのものでないと考觉ている.

応答: 名大環研 石原一郎 Angiotensin に対する副腎静脈血中 11OHCS output の立ち上りは著 明である. Single shot の場合には $10 \mu \mathrm{g}, 20 \mu \mathrm{g} / \mathrm{min} 5 \mathrm{~min}$ 間を行なつている。この実験例で ACTH 投与 の反応をも見ているが，同様浪い高い peak が出ている.

115. クロール゚プロマジン慢性投与動物における間脳下重体副腎皮質機能について 北大精神科 誀訪 望, 大野寺勇夫, 諸治 隆翮, 岡田 文彦, 伊藤 耕三
山下 格 クロールプロマジン (CP) の間睬下垂体副眚皮質系に対する作用については現在なお不明な点が多い。 わ れわれは CP 慢性投与動物における間脳下垂体副腎皮質機能について検討をした。方法：Wistar-King 系 雄ラット $(150 \sim 230 \mathrm{~g})$ KP $3 \mathrm{mg} / \mathrm{kg}$ および CP $15 \mathrm{mg} / \mathrm{kg}$ の腹腔内注射を21日から30日間行ない, ACTH の basal secretion, さらに exogenous ACTH, lysine-8-vasopressin, ether, sham operation, Insulin hypoglycemia および音響刺激などに対する反応性を血中コルチコステロン值 (CS) を指標として観察した. 血中 CS 值は Mattingly 法で, また血糖值はオルトトルイシン法により測定した. 結果 : (1)血中 CS 分泌 の日内リズムは CP $15 \mathrm{mg} / \mathrm{kg}$ 投与後次第に不明瞭となり，第18日目頃より消失した。 しかし投与中止後 7 日目以降にはほぼ回復した。 (2) exogenous ACTH および lysine-8-vasopressin に対しては対照群と同程 度の上昇をみた。 (3) Insulin hypoglycemia では投与 6 時間後にも血糖値は投与前值に回復せず，また血中 CS 值は比較的高值を示した. (4)その他の stress に対しては対照群との閻に有意差はなかつた. 以上の結果 と血中 CS 分泌の日内リズム発現に大脳返緣系および中脳網樣体が関与していること, また脳内分布で CP が海馬に高濃度かつ数日間にわたり䝰溜するという報告をあわせて検討するとき, 慢性投与時 GP は大脳辺 縁系を介して視床下部下垂体体副踿皮質系に作用すると推測される.

質 問 : 名大環研 松井 信夫 この際動物の睈眠覚醒のリズム及び活動性のリズムは消失しててるか.

忍 答: 北正精神科 小野寺勇夫 CP 慢性投与群についでは行動量の測定はしていない。しかし臨床的 には対照群と比較して著明な养異はない，CP 投与後ラットはいわゆる dösig にはなるが schlafenしてい る状態とはいえない，睡眠覚醒りズムパターンとの関係については今後榆討したい.

質 問：阪大山柇内科 熊谷 朗 私共は精神科の人と共に分裂症患者に CP 100 300mg/日長期間投 与した場合, dexamethasone $3 \mathrm{mg} /$ 日 3 日間投与した場合まつたく尿中 17-OHCS 排泄量がさがる反応は認

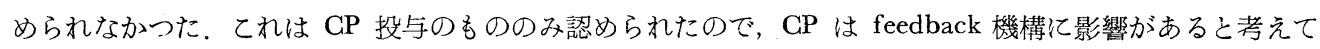
いる.

応 答: 北大精神科 小野寺勇夫 CP 慢性投与例决 Dexamethasone supprersin test は行なつ ていない. 急性投与実験では Dexamethasone $1 \mathrm{mg} / \mathrm{rat}$ S.C. を行ない，3時間後に CP 15mg/kg i.p. を行 ない，1時間目の血中 corticosterone 值は低值を示し，ACTH release は suppress されると考えられた。

116. 簡易脳下垂体副篎皮質機能検査法（第 3 報）

岡大大藤内科 小川 紀雄, 高原 二郎, 大藤 真 従来の脳下垂体副腎皮質機能検査法は長期間を要し, 血中 Cortisol の日内変動, 成長ホルモン (HGH) の分泌動態が不明であつた。我々は血中 Hormone を指標としてわずか 3 日間で実施できる簡易脳下垂体副 腎皮質機能検査法 Simplified Hyophyseo-Adrenocortical Function Test (SHAFT) を考案実施して来て おり，すでに本学会でも発表したが，今回は成長ホル、モンの動態を中心に他の検査法と比較検討した．方法 : SHAFT は第 1 日目血中 Cortisol の日内変動, 同夜から 2 日目にかけて Single Dose Dexamethasone Suppression Test, 第 2 日目 Pyrogen Test (又は Insulin Test)，第 3 日目 Rapid ACTH Test を各々 
行ない，血中 Cortisol は Rudd の方法, HGH は二重抗体法による Radioimmunoassay により測定し た. Lysine-8-Vasopressin (LVP) Test は合成 LVP 4 単位静注法にて行なつた. 結果: 前回の結果では 検査法により Cortisol の分泌動態に多大の違いが認められたが，HGH は Insulin に最もよく反応し， LVP にはあまり反応を示していない. Pyrogen Test 及び Insulin Test 相互間の HGH 反応はぼ゙正の 相関傾向がみられるが，両者の反応性に解離する例が存在する. 又 Insulin Test 時の Cortisol, HGH の 反応量の関係は多くは正の相関傾向がみられるが，中には前者の反応性が少なく, 後者により多く反応して いる一群が存在した．次に Pyrogen Test, Insulin Test 及び LVP Test 時の同一サンプルによろ Cortisol, HGH の parallel assay の結果は両者の明らかに解離する例がかなりあり, collagen disease では一 般に HGH の反応性が亜いが，Cortisol の反応性の方がより悪い例が多かつた。 今後脳下垂体副腎皮質機 能検査では Cortisol 測定と共に HGH の測定が必要であると考えられる. 最近 Hawley らが視床下部下 垂体副腎皮質機能の Simple Twenty-Four Hour Test を発表しているが，彼らの方法では HGH 測定も， 更には視床下部下垂体の「予備能」検査, たとえば Pyrogen Test, Insulin Test 等を行なつていない点, Stress 時の Releasing Factor 分泌機構の異常を推定することが出来ないので我々の行なつている予䚚能力 検査をも加味した SHAFT が有用であると考えられる.

117. Fluothane 麻酔抢よび手術侵襲の人の下垂体前葉機能に及ぼす影響

弘前大麻酔科 滝口 雅博, 工藤 剛, 尾山 力

フローセン麻酔及び手術侵襲の，人の血中 ACTH 濃度及び Hydrocortisone (17-OHCS) 濃度に及ぼす 影響を研究する為に，10名の手術患者にフローセン一笑気麻酔を行ない，麻酔及び手術中におけるてれらホ ルモンの血中濃度を経時的に測定した。 ACTH 濃度は Lipscomb-Nelson 法の井村氏変法, 17-OHCS 濃 度は Rudd 氏螢光法により測定した。麻酔導入前の血中 ACTH 濃度は全例 nondetectable で $1.0 \mathrm{mU} /$ $100 \mathrm{ml}$ 以下であつたが，麻酔開始後20分では10例中 9 例は $1.0-3.8 \mathrm{mU} / 100 \mathrm{ml}$ に上昇し， 1 例は $15.5 \mathrm{mU} /$ $100 \mathrm{ml}$ と著明な上昇を認めた。しかし，麻酔開始後40分では10例中 7 例は再び nondetectable に低下した。 手術開始後30分では再び全例に血中 ACTH 濃度の上昇を認めた。一方 17-OHCS 濃度は麻酔竞入前（朝 8 時 30 分）では平均 $14.4 \mu \mathrm{g} / 100 \mathrm{ml}$ であつたが，麻醉開始後 20 分では $17.5 \mu \mathrm{g} / 100 \mathrm{ml}$ に上昇し, さらに麻酔 開始40分, 手術開始後30分でもさらに上昇を続けた。すなわち, 血中 ACTH 濃度は 2 峰性の增加を示し, 血中 17-OHCS 濃度は階段的に上昇した。 以上により，フローセン麻酔は下垂体一副腎皮質系を刺激するこ とが示唆される。

質 問：阪大第一外科 浜中 雄二 (1)フローセン麻酔剤が下垂体副腎皮質系を刺激すると考えるか. 挿 管操作の影響を考慮するべきと考える。つまり㧴管をしない，吸入によるフローセン麻酔を行なつた症例に ついて検討されたか。、スライドでみると Plasma 17-OHCS はさほど著明な増加がないように見受け, 手術 後著明に. 増加しているとてろをみると手術の影響がはるかに大きいと考える. (2) 我々も約25例の Major Surgeng の plasma cortisol の変動を測定したが，插管後約15分後では control に比べ unconjugated cortisol は軽度上昇したが日内変動の範囲内にあつた。一方 nonprotein-bound cortisol は日内変動の範囲 以上の高值を示している。 日内変動レベルとの関係について検討されたか. つまり plasma ACTH，17OHCS の日内変動を測定しているならば教えていただきたい.

応 答: 弘前大麻酔科 滝口 雅博 插管操作及び日内変動による影響に対して, 我々は40回の本会で 報告したでとく麻醉開始15分でも血中 17-OHCS 濃度は上昇しており，さらに，導入開始が 8 時 30 分で, それ以後の血中 17-OHCS 濃度は日内変動に従つて低下するのが normal であるにもかかわらず，血中 17-OHCS 濃度が上昇するととより，フローセン麻酔は下垂体一副腎皮質系を刺激するものと考えられる。 尚插管操作が刺激になる事も否定は出来ない。

118. 膠原病疾㭧に於ける内分泌学的研究（第 1 報）

岡山中央病院 橋本 浩三

岡大第三内科 大藤 真, 高原 二郎, 小川 紀雄 
膠原病に於ける内分泌機能を检討するため今回は，未治療ないし，ステロイド治療後一ケ月以上の膠原病

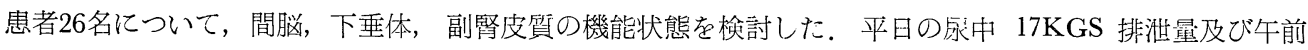
9 時の plasma cortisol level の測定, 間脳下垂体機能検査として cortisol の日内変動, Metopirone Test 亿於汀る尿中 17KGS, pyrogen, insulin, LVP 等の負荷状態に於ける plasma cortisol 及び GH の反応 を測定した. 又副腎皮質機能検査として ACTH-Z test, Rapid AGTH test を行ない, 又尿中中性ステロ イド代謝産物の分画を，gas liquid chromatography を用いHorning-池川の方法により分析した。膠原病 患者飞於て平日尿中 $17 \mathrm{KGS}$ 及び plasma cortisol は正常ないし，いぶん低值を示していたが，ACTHZ test 及び Rapid ACTH test そ於ける反応は正常のものがほとんどであつた. 又 metopiron test 亿於 ける反応も正常のものが多く膠原病に於ては cortisol の negative feed back 機構汇は障害を来してない てとが推測される。しかし pyrogen, insulin, LVP に対する plasma cortisol 及壮 GH の反応をるると SLE, Behget 症候群等で反応の低下をみるものが多く, Scleroderma 等に比較して SLE 亿於てはストレス 飞対する AGTH 及び GH の反応性の低下が考光られる。ステロイド分画比に於いて $\frac{\mathrm{THF}}{\mathrm{THE}}$ は control 群（12名）の0.65 \pm 0.21 亿比し, 胗原病患者（10名）に於ては $1.5 \pm 0.62$ と上昇をみ, $\frac{11-\mathrm{OH}}{11-\mathrm{Keto}}$ も control 群の $0.70 \pm 0.17$ 亿比し $1.18 \pm 0.28$ と上昇を認め, 11-hydroxy の代謝系路が 11-Keto の代謝系路より優势な ことが考光られる. 次に $\frac{20-\mathrm{OH}}{20-\mathrm{Keto}}$ も胗原病患者に於て上昇の傾向がみられ, 膠原病患者に於いて Reiclesteine substane E，U を介する系路が正常状態より優勢なととが推定される。 $\frac{11 \text {-oxy Steroido }}{11 \text {-deoxy Steroids }}$ 即 ち oxygenation rate 及び $\frac{11 \text {-oxy 17-OH } \mathrm{C}_{21} \text { Steroids }}{11 \text {-deoxy } \mathrm{C}_{19} \text { Steroids }}$ は膠原病男性患者に於て低下傾向を認めたが，例数 が少なく確定的なととはいえない。 $\frac{11 \text {-oxy・17-deoxy } \mathrm{C}_{21} \text { Steroids }}{11 \text {-deoxy 17-OH } \mathrm{C}_{21} \text { Steroids }}$ は control 群と膠原病患者との間に差 違を認め得なかつた。

質 問：京大第二内科 岩井 一義 SLE, Sjogren の例に抗副腎抗体を証明したものがあつたか。いわ ゆるSchmidt 症候群のようなものはなかつたか. 肝機能は反応の低いもので正常でしたか.

質問：九大温研内科 河村 富夫 (1)膠原病における肝機能障害を除外したとのととであるが，膠質系 反応の異常も考虑したか. (2)血中コルチゾールの変動, AGTH テストなどで数例の低下を認めているが, ステロイドの使用群と非使用群とを分けて，データの分折を行なつたか.

応 答: 岡山中央病院 橋本 浩三 副腎予備能は正常と考光る。1) Metepiron Test, ACTH Test 亿 於ける反応低下を示したものは Behcet, Sögren そ多く，てれは以前に使用したステロイドの影響が考元ら れる。抗副腎抗体については測定していない，Leber の障害のあるものは除いてある．2）ステロイド使用 群と非使用群について検討しでみたが，Behcetに於て，その影響がみられたが，その他の疾患では影響は みられなかつた。肝機能障害のないというのは GOT, GPT の上昇がないものという意味である。 RA 亿 ついてはすべてステロイド非使用例である。

119. Sarcoidosis の下垂体前葉機能

$\begin{array}{lllll}\text { 阪大中検 } & \text { 熊原 雄一 } & & & \\ \text { 阪大阿部内科 } & \text { 宫井 潔, 岡田 } & \text { 義昭, 井上 } & \text { 雅, 阿部 裕 } \\ \text { 大阪府立病院 } & \text { 立花 暉夫 } & & \\ \text { 結核予防会大阪支部 } & \text { 高瀬喜多郎 } & & \end{array}$

胸部X線および右斜解筋リンパ節, 肝, 耳下腺, 皮膚等の生検によつて診断された年令12〜28才の sarcoidosis 患者 9 例（うち男子 7 例, 女子 2 例）を対象とし, 主として成長ホルモン $(\mathrm{GH})$ 分泌およびメ卜 ピロンテストによる下垂体前葉機能について検索した. GH は insulin 負荷後における血中值を radioim- 
munoassay そより，ACTH はメトピロンテストにより，それぞれ分泌予備能について検討，TSH および gonadotropin 分泌は甲状腺機能, 性腺機能㧍よび臨床症状により綜合的に判定した。 Insulin 負荷後の血 中 $\mathrm{GH}$ 最大值は 9 例中 8 例が $14.7 \sim 64$ 以上 $\mathrm{m} \mu \mathrm{g} / \mathrm{ml}$ と正常值（14m $\mu \mathrm{g} / \mathrm{ml}$ 以上）を示した。またたトピ ロンテストでは 8 例中 7 例において尿中 17-OHCS が前值の $2.6 \sim 5.9$ 倍に上昇, 正常範囲（前值の 2 倍以 上）にあつた。尚 9 例とも甲状腺機能および性腺機能に異常は認められなかつた。 9 例中 1 例は，12才の男 子で, 胸部X線において BHL および肺野病変をもち, 左右斜㓩筋りンパ節と肝生検に sarcoidosis の所見 を認め, 眼その他の胸廓外りンパ節にも病変が進展した12才の男子で, insulin 負荷後の血中 GH 最大值 は $10.5 \mathrm{~m} \mu \mathrm{g} / \mathrm{ml}$ と低く, またメトピロンテストにおいて尿中 17-OHCS は前值の1.75倍にしか上昇せず, ACTH-Z テストでは前値の3.7倍に上昇した。乙の症例は6ケ月間のステロイド治療により極く軽度の BHL を残すだけとなり，乙の時点で insulin 負荷およびメトピロンテストを再検したととろ，血中 GH 值は $64 \mathrm{~m} \mu \mathrm{g} / \mathrm{ml}$ 以上, 尿中 $17-\mathrm{OHCS}$ は前值の 2.2 倍に上昇,いずれも正常に復した。. 以上より sarcoidosis 患者にわいて，病変功視床下部・下垂体系にも及ぶてとを示唆する成績を得た。

120. 人工腎臓による血液透析時の間脳・下垂体・副腎系の

反応態度について

京大泌尿器科 川村 寿一, 土屋 正孝, 山下 橗世, 三宅ヨシマル, 上山 秀磨 小林 啓躬, 沢西 謙次, 加藤 篤二

京大深瀬内科 岩井 一義, 本田 弘

慢性血液透析患者について，透析の stress としての侵襲的立場から，透析中に間脳・下垂体の上位中枢 が副腎皮質機能に及ぼす影響をしらべた。 1. Cortisol の日内変動，1日の正常の cortisol リズムの中に 血液透析という stress が反復して入るととにより，視床下部を中心とした resting レベルでの ACTH 分 泌機構が乱れ, その結果, 日内変動の少ない, 即ち夕方から梁夜にかけて最低となる変化が少ない原因の一

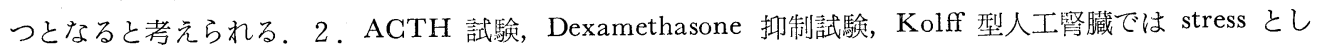
ての要因が大きいため透析前半は内因性 AGTH の, 透析後半は外因性 AGTH の影響を強く受けて血中 cortisol は增加する，Kiil 型では，透析中を通じて，外因性 ACTH の影響を強く受け，内因性 ACTH 分泌はわずかであると考えられる. dexamethasone 投与により, negative feedback の条件下の透析では Kiil 型でよく血中 cortisol レベルは抑制されるが，Kolff 型では抑制効果はあつても ACTH 分泌を抑え ることは出来ない. 3. Metopirone 試験. 透析中に metopirone を投与し, feedback 機構を抑えて cortisol 産生を低下させても， cortisol レベルの低下は抗らない，4. 透析中の stress に対する反応は negative feedback では説明のつかない他の機構が働いて AGTH の分泌が行なわれているものと推定さ せられる。

質 問 : 阪大第一外科 浜中 雄二 (1)演者は人工腎臟の種類によつて plasma cortisol level が上昇す るもの, 低下するもの，あまり変化しないものがあるといわれたが， uncojugated cortisol level が上昇し なくても nonprotein-bound cortisol level に興味ある結果が得られるのではないかと考えるのでての点か ら検討していただきたい.

応 答: 京大泌尿器科 川村 寿一 Protein bound cortisol については, まだ測定していない.

質 問：阪大山村内科 熊谷 朗 血液透析時に失われる cortisol の量的な問題をおたずねしたい. 先生は主として stress を中心として plasma corticoid を考えられておられるようだが，

応 答: 京大第二内科 岩井一義 血液透析に於ける cortisol の loss をどうして測定して居られるの か. 透析波の量の問題で仲々正確なデータが得られていないので.

応 答: 京大泌尿器科 川杪 寿一 血液透析膜からの cortisol の菲失は余りないように思う（透析膜 通過前後の血中レベルの測定結果から）しかし，長時間の透析時の cortisol の動態については $\mathrm{C}^{14}$ cortisol を使つて検討する予定であるが，莫大な量の透析液中の cortisol の測定法が不十分な段階である，更に検 討する. 
121. 浮腫疾患に於ける副腎皮質機能に関する研究

$$
\begin{gathered}
\text { 神大第一内科 南 礼三, 北川 博之, 森 淑子, 児島 愈, 日吉 保持 } \\
\text { 長井 勇, 友松 達弥 }
\end{gathered}
$$

浮腫疾患に於ける Hormonal factor の関与について検討し, 特に Angiotensin 及び ADH そついては 浮腫形成時に於けるそれ等 Hormone の増加を認め, 浮腫を増悪させる一因子となつている事を明らかに して来た，今回は $\mathrm{ADH}$ と共に，水代謝に関与する副腎皮質機能について，血中 cortisol 值を測定し検帏 を加えた．血中 Cortisol 值は Rudd の螢光比色法により測定した。血中 cortisol 值測定に際して, 採血 時間決定の為に日内変動を観察した。正常者に於ては朝から正午までの午前中に高值を示し, 午後より夜に かけて低値を示した。一方浮腫疾患では，一日を通じて殆ど变動なく夜間には正常者とほぼ同様の値を示し たが，午前中には明らかに低值を示した。 そてで午前10時より正午迄の間に採血し測定すると正常者では $9.3 \pm 1.9 \mathrm{mcg} / \mathrm{dl}$ であり, 浮腫疾患では $6.0 \pm 1.7 \mathrm{mcg} / \mathrm{dl}$ であつた. 次に合成 ACTH の投与に cortisol 值 の変動を比較すると浮腫疾患では正常者に比べ明らかに反応の低下が認められた。更に, Metyrapone test による cortisol 值の反応を観察したが, 正常者, 浮腪疾患の閪に特に有意の反応の差を認め得なかつた。

以上より浮腫笑患に於ては，副腎皮質機能の低下か摊察され，又日内変動にて平担な pattern を示し，生 活の Rhythm の失なわれている事が観察された。

122. ターナー症候群の副腎機能

名市大産婦人科 八神 喜昭, 水野金一郎, 花田 征治, 鈴森 董 ターナー症候群においては, 性腺機能の異常を示す報告が多数見出される。乙のととはての症候群におい ては性腺以外の他の内分泌機能にも何らかの異常を示す可能性が考元られる。我々は今回 2 例のターナ一症 候群において，副腎皮質の機能を検索すべく，尿中 17OHCS，17KS について測定した結果次の如き結果 を得た１）ターナー症候群においては 17OHCS, 17KS な低值を示したが, ACTH test・Metapiron test に反応が見られた。然し Dexamethasone による効果は認められなかつた。 2) 17KSもやや低值を示した が, 各 test による $17 \mathrm{KS}$ 分画では対照に比して, やや変動が見られるようである.

追 加：京大第二内科 井村 裕夫 凉第二内科において最近 2 例の XX-isochromosome を呈した Turner 症候群を経験したが，その下垂体機能について追加する。第 1 例は metopirone test ではほとんど 反応せず，HGH はインスリン低血糖には無反応，アルギニンには反応した。尿ゴナドトロピンは低值だつ た. 第 2 例は metopirone test で subnormal な反応を示し, HGH のインスリン, アルギニンに対する 反応は正常下界，尿中ゴナドトロピンは正常だつた。従つて Turner 症候群では下垂体機能に異常がある 場合が少なくないと考光追加する。

応 答: 名市大産婦人科 水野金一郎 我々の経験した. Turner's Syndroms の尿中 17OHCS は Metopirone test そ対ては反応し, Dexamethazone そ対しては反応していない, 従つててれら患者では, possitive 或は negative feedback 機構において, hypothalamus-pituitary 系の Response に差があるかどうか を示すデーターがあれば御教光願いたい。

追 加: 東北大鳥飼内科 勝島 一郎 現在私は $40 \mathrm{X}$ isochromosome X と思われる Turner 症候群の 患者をもつているが，GH は insulin 低血糖及び arginine 負荷に対してほとんど反応しなかつた。やや り Turner 症候群に於ては下垂体機能不全を伴うものがあるものと考えられる。

追 加：鳥取大第二内科 原田 義道 異型 $\mathrm{Y}$ 染色体を有し, XO/XYモザイクによる侏儒症の17例：わ れわれも31例の Turner 症候群について尿中 17-KS, 17-OHCS 排泄量の著明な低下を認めた。その中に 興味ある 1 例を発見したので追加報告する. 患者は 10 才の侏儒症で, 父母は血族結婚であり, 臨床的に典 型的な Turner 症候群とはいえないが, 治療により身長増加率がわるいので再検した結果, 試験開腹で畉 栄あるいは精巣を認めず, Sex chromosome は 45, XO：24\%, 46, XY : 76\% のモザイクで，てとにY染 色体が写真の如く, あたかも双球菌様の異型を示し, 他に類似がないので追加報告した。

質 問：岡大精神経科 高坂 睦年 Dexamethasone supression-T に対して 17-KS 分画総量は低下し 
17-OHCS は変らなかつたととに関して 17-KS 分画值の中で何か特徴はなかつたか. DHA 或は Testosterone 值は如何だつたか.

応答: 名市大産婦人科 花田 征治 Turner 症候群の Stimulation Suppression test において 17KS の分画の中，いわゆる副腎分画といわれる 17-OXO.17-OH 分画の変動がやや Control に比して，認め られる様であるが，現在検討申である。

質 問 : 新大第一内科 近藤隆 男性化症状, とくに陰核肥大などの症候は認められなかつたか.

応 答：鳥取大第二内科 原田 義道 此の症例では精桕を認めず，陰核の肥大は軽度に認められたが， anabolic steroid で 1 年間治療されているので，その為も考えられる.

123. 副腎皮質ホルモン大量投与によるコルチゾール 1 日分泌量およびその代謝に及ぼす影響 東京医歯大大淵内科 小泉 精策, 大西 康, 大貫 稔, 星野 弘弶 長期大量ステロイドホルモン投与時に副腎皮質機能低下を来すととは周知であるが，今回われわれは，そ のような症例に対し， ${ }^{14} \mathrm{G}$ コルチゾールを用いて，コルチゾール 1 日分泌量およびその尿中代謝産物を測定 し, 皮質機能低下の程度さらに, その恢復の過程を追求した. 対象は, ネフローゼ症候群, 再生不良性貧血, エリテマトーデス等の基礎疾患より，ステロイドホルモンの長期大量投与を行なつた10例であり，てれらの

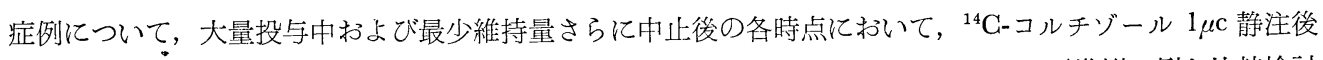
の血中半減期，及び24時間蓄尿から TLG を用いて一日分泌量等を測定し，乙れを正常例10例と比較検討 した，その結果コルチゾール分泌量は，長期大量投与中は正常例 $1 / 5$ 以下に減少するものが多く，また，尿 中コルチゾール代謝産物には買常を来すものが多かつたが，最少維持量投与時，さらに中止後には，かなり 正常に近づく症例も認められた。

124.ステロイドホルモン投与者の下垂体副䇣皮質機能

昭和大第一内科 大井 董一, 永野 聖司, 杉田 玄, 斉藤 恵男, 川上 保雄 從来より各種疾息の合成ステロイド療法による副腎皮質の形態学的萎縮が認められでいるが, 今回気管支 喘息患者を中心としてステロイドホルモン投与者に, Insulin 試験と ACTH 試験を行ない, 血中Cortisol と $\mathrm{GH}$ 等の反応について検討した。 ステロイドホルモン投与者を Prednisolone 換算で $2000 \mathrm{mg}$ 以下投 与群，2000 $5000 \mathrm{mg}$ 投与群， $5000 \mathrm{mg}$ 以上投与群の 3 群に分類し, 非使用の老年及び若年の対照群と比較し た. 正規 Insulin 4 単位静注試駼において, 血中 Insulin は15分で頂值に達し，逆に血糖は30分で最低を

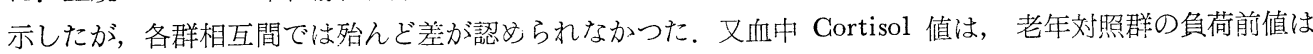
$10.1 \mu \mathrm{g} / \mathrm{dl}$ で, 負荷後60分まで上昇し，その後180分まで漸減した。若年群の前值は老年群と差がなかつた が，180分では殆んど前值に復帰した，2000mg以下投与群では老年群と殆んど差がなかつたが，2000〜 5000 $\mathrm{mg}$ 投与群ではやや反応の抑制が見られ，5000 mg 以上投与群では明らかな低值を示し，8例中 5 例では全経 過を通じて $4 \mu \mathrm{g} / \mathrm{dl}$ 以下であつた. 又 $\mathrm{GH}$ 值も Cortisol 反応と同様な傾向がみられ，2000～ $5000 \mathrm{mg}$ 及び $5000 \mathrm{mg}$ 以上投与群においで反応の低下が璆められた。ACTH 試験は, 試験前夜 Dexamethasone $1 \mathrm{mg}$ を 経口投与し，1〜24 ACTH 0.25mg を30分間点滴で負荷したが，血中 Cortisol の老年対照群での負荷前值 は $4.5 \mu \mathrm{g} / \mathrm{dl}$ 点滴開始後 60 分值は $23.2 \mu \mathrm{g} / \mathrm{dl}$ と急速に上昇し, その後も 120 分までやや上昇の傾向を示した。 2000mg以下投与群ではほぼ同じ反応を示したが，2000～5000 mg 及び5000 $\mathrm{mg}$ 以上投与群では前值も低く負 荷後の上昇もゆるやかで反応の低下が認められた。 又 $\mathrm{GH}$ 值は，60你值においてやや削值より上昇する傾 向が認められたが，备群相互間では差が認められなかつた。 Insulin 及び血糖についても特別の傾向は認め られなかつた。両試験を共に施行した11例についてみると，Insulin 反応で Cortisol と GH が低值を示 すものは, ACTH 試験においても又低值を示し，特に5000 mg 以上投与者において著明であつた.

質 問: 京大第二内科 吉見 輝也 1) 血中 Cortisol Assay に馬 CBG を用いておられるが，その理 由如如何. 2) 本測定法による血漿 Cortisol の正常值は. 3) 同一試料について CPB 法と螢光法との 相関を検討されていたら教えて載きたい.

質問: 千葉大小児科 成瀬 孟 我々は最近, 各種ステロイドの副腎皮質機能抑制の差, 治療効果お 
よび副作用発現の差の有無を検討（演題125）している，只今の研究では全てのステロイドをプレドニゾロ ン換算してあるが，ステロイドにより差を認めたかどうか.

応 答: 昭和大第一内科 斉藤 恵男 1) Horse CBG は Cortisol 以外の 11-deoxycortisol, corticosterone 等の影響が Human, Pig, Sheep 等に比べて少ない様なので使用した。 2) 早期空腹時 Cortisol lebel は我々の成績では $10 \sim 11 \mu \mathrm{g} / 100 \mathrm{ml}$ です，3）螢光法との比較については今後検討してみたい，4）各種 ステロイドホルモン毎に別個にその抑制作用を検討したととはまだない.

125. Corticosteroid 隔日投与と副粲皮質機能（第 2 報）

千葉大小児科 加藤 元一, 中島 博徳, 森 和夫, 村田 光範, 中田 益古 成瀬 孟, 久保 政治

副腎皮質ホルモン隔日ホルモン隔日 1 回投与法は，下垂体副腎皮質系の抑制が少く，小児科領域では，ネ フローゼに屡々用いられている。本法が，下垂体副腎皮質系に及ぼす影響については，前回の本会で，血中 Cortisol 日内変動, AGTH 試験を指標として検討した結果を報告した。その際, 隔日 1 回投与法のネフロ 一ゼ患児では，大部分に下垂体副腎皮質系抑制が見られたが，一部に日内変動，AGTH 試験が正常に保た れている例があつた。 ての中には Prednisolone (P) で治療中の例が多かつた。 そてで今回は，P隔日投与 群と Betamethasone (B) 隔日投与群に対して, AGTH 試験を施行して両群の反応を比較し, 又, 治療郊 果と副作用発現の状沉についても比較した。血中 Cortisol 測定は, 教室の ${ }^{3} \mathrm{H}-$ Prednisolone Resine 摂取 率に依つた。 ACTH 試験について $\mathrm{P}$ と を投与量別に分けて比較すると，大量投与時（ $\mathrm{P}$ 換算 $30 \mathrm{mg}$ 以上) 中等量投与時 $(30 \sim 10 \mathrm{mg})$ では，Pは反応良好であるが $\mathrm{B}$ 注不良な例が多く，有意の差が見られた，少量 投与時 (10mg以下) では両者の差はなかつた。治療効果では両者の差はなかつた。副作用については，Bは $\mathrm{P}$ に比べて有意の差で, 早期出現の傾向があり，また全期を通じての出現頻度が高かつた。身長増加につい

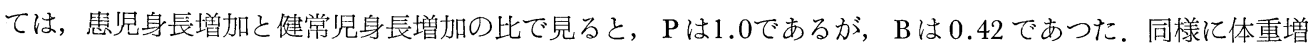
加の比は夫々 3.0，5.5であつた P 1 回投与後の ${ }^{3}$ H-Prednisolone Resine 摂取率の推移によつて，副晸抑制 の持続を見ると，48時間後でほぼ回復している。一方，B 1 回投与後では48時間後も回復しない例が多い. 從つて隔日 1 回投与法では，副腎の代謝を回復させる為に short acting steroid たる $\mathrm{P}$ 等を用いるべきで あろう。

追 加: 千葉大小児科 中島 博徳 今回の prednisolone, betamethasone の比較実験では予期に反し て副繁抑制作用の著しい差が出た。前者が short acting であるとする機序は不明であるが，ての様な差が 明らかである以上長期 steroid 投与には prednisolone や hydrocortisone を選ぶべきと痛感する。

質 問: 群大薬理 小川 治克 Prednisolone と betamethasone の実験結果における相違は glucocorticoid-category の範囲内で惹き起てされた生理学的変化か, 若しくは別な chemical compounds そよる変 化として考えるべきか, prednisolone だけなぜ特別に考えられるべきなのか.

質 間：阪大山村内科 熊谷 朗 先生は predonisolone と betamethosone のちわ゙いね short acting と long acting として受けとめられているが，てれはそれぞれの metabolic action の相違がすでにある 故でなからうか.

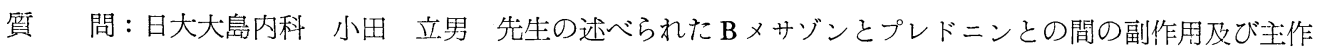
用の相異と，それぞれ構造式の特異性との間に何か関係があつたか.

応 答: 千葉大小巟科 加藤 元一 (1)メタボリック, アクションについては, 今回は臨床的検討を主に

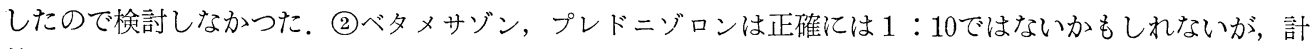
算の簡便上 $1: 10$ とした.

126. 欠 演

127. 二, 三疾患時における血中遊離型 cortisol の変動について

日大板橋病院大島内科 大島 研三，小田 立男，鈴木 英生，谷口 光，石橋 凱夫 佐々木寿彦，○末盛 英雄 
血中遊離型 Cortisol の指標としての血中 11-OHCS の螢光測定法も進歩し, これにより諸秝患時に於け る血中 Cortisol の動きが追求可能となつて来た，我々も臨床面への応用を試みるべく過去数年来測定法の 比較検討を行なつて来たが，特にその中で代表的と考えられるVan der Vies 法, Rudd 法, DeMoor 法, DeMoor 改変法, 及び Steenberg 法について検討を加えた結果, DeMoor 法と Mattingly 法の折東法と も考光られる DeMoor 改変法が手技が非常に簡単であり, 螢光溶媒重畳後 5 分以内に測定することにより Corticosterone 螢光の影響も避けられ比較的安定した值が得られることから, 以下本法により 2,3 疾患に ついて検討を試みた。本法の臨床面への応用法として我々は扭林氏等により提唱されたに rapid combined test そ順して実施した。先づ年令, 性別の区別のない10例の正常者群では午前 9 時值は $10 \sim 25 \gamma / \mathrm{d} 1$ ，午後

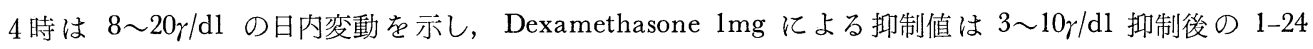
ACTH 反応值 19-42 $/ \mathrm{dl}$ を呈した。高血压, 過血桾等のない平均体重 $+15 \%$ 以上の肥満者 5 例の測定結果 は年前 9 時值は正常者比しやや高值．抑制值 $10 \sim 20 \gamma / \mathrm{d} 1, \mathrm{AGTH}$ 成応性はむしろ正常者より高值を示す

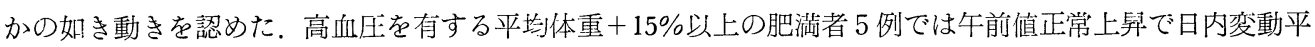
担型，抑制効果に乏しくクッシング症候群類似の傾向がみられ今後検討を要するグループと思われる．甲状 腺機能方進症 4 例值は午前は正常上昇, 午後は正常者より高值で中 2 例は午後值の方が高值, 抑制は正常。

ACTH そ対しては反応不全傾向老認めた。斗状腺機能低下症 3 例では日内変動は正常型，Dex. 抑制は不 全型で AGTH に対しては過鄱反応の傾向を認めた。乙れらは井林氏等の結果とよく一致している。筜血 管高压症例では日内変動傜しく何れも高值を呈しており Robert. Cade 等による報告例に相当すると思わ れ今後レニン・アンギオテンシンアルドステロン系の動きと共にレニン・アンギオテンシンコーチゾール系 の追求も行ないたい，以上今回の方法はやや高値を示すが，非常に簡便であり，比較的よく血中コーチゾル の動きを反映すると考光られたので, 今後対象群の巾を拡げ例数をふやして更に動態を追求したい.

質 問: 京大第二内科 井村 裕夫 Single Dose Suppression Test の場合, 神経質な患者では抑制不 立分で，鎮静剤を投与するとよく抑制された経験があるが，鎮静刜の投与をなさつておられるか。

応 答: 日大大島内科 末盛 英雄 今回は併用して行なつていない.

質 問: 阪大第一外科 浜中 雄二 (1)演者の正常者之肥満者の午前 9 時と 4 時の日内変動ではあまり差 が無いようにうかがわれる。もつと細かい時間々隔で正確に測定されれば明らかな変動がみられるのではな

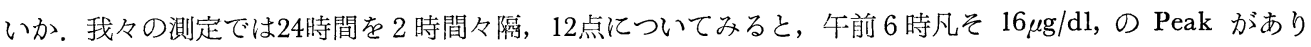
真夜中に凡そ $3 \mu \mathrm{g} / \mathrm{d} 1$ の最低值を示す pattern を示し, 又午前 $8 \sim 10$ 時と午後 4 時では明かな日内変動の 差がるられる。(2)我々の測定した対象は，全て入院中の外科突患々者で，（成人男女子）腎，肝機能に異常 なく臨床的に内分泌的異常の認められないものである. 全て nonstress の状態で測つている. (3)方法は関・ 松本の開発した Amberlite IRC-50 の column chromatography で unconjugeted cortisol corticosterone を分画し，硫酸エタノールで螢光測定している。

応 答：日大大島内科 末盛 英雄 一見，表からは内変動に乏しい印象を受けるが，対象群には外来患 者も含まれており，特に外来患者において日内変動に泛しい結果が多くみられた。入院患者については日内 変動がよく認められている。

応 答: 日大大島内科 小田 立男 我々は抄録に述べた如き色々の螢光法を試み, 比較的簡単でしかも 臨床面に於ける変動を示すものとして，乙てに提示したわけで，勿論てれ以上 purify してやれば良いと思 うが, 方法は繁雑となり, 時間もかかる。我々の方法で允分に日内変動, dexamethasone の抑制, AGTH 刺激効果等をよくあらわしていると考えている。なお今後の検討を要すると思う。

応 答 : 日大大島内科 谷口 光 臨床的に出来得る限り簡便でしかも臨床的変化の表現が可能な方法 としてあえて本法を使用した、デキサメサゾン抑制值も本法で $5 \gamma / \mathrm{d} l$ 以下を示す頻度も多く動態の表現が充 分なされているものと考える，その他 2,3 の測定法の検討を行なつている. 更に今後本法にて検討を行な つてみたい.

質 問 : 岡大第三内科 高原 二郎 1) Heparin が螢光発色に影響を及ぼしていると考学られるがての 第 45 巻 第 4 号 
点御娭討でしたらお教え愿いたい，2）Rudd の方法で Cortisol た抽出しても Gas Chromatography に かけると大量の Cholesterol を含んでおりてれが螢光発色に影響を及ぼしているとも考光られるかどう 御考えか. 3）私達も外来患者に於いて Cortisol の日内変動をるているが，やはり入院患者に比較して 午後 4 時の Cortisol 值はいく分高値を示している.

応答：日大大島内科 谷口 光 コレステロールの影響は充分考えられるとてろであるが，螢光法に

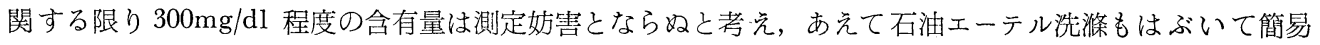
性の増大を計つた。へパリンによる影響をさけるため, 我々はヘパリン処理器具は使用せず, 採血直後に プラズマ分離を行なつている。

128. Sephadex LH-20 を使用する $17 \mathrm{KS}$ および $17 \mathrm{OHCS}$ の分離定量

$$
\text { 阪大遗伝関 得一郎 }
$$

第二内科 管瀬 透, 西川 光夫

Sephadex LH-20 は脂溶性化合物の分離に適した分子小るいであるが，水酸基の数を異にするグリセリ ド相互の分離に使用できるととが報告されている，我々は $17 \mathrm{KS}$ および $17 \mathrm{OHCS}$ をそれらの有する水酸 基の数により分画できるクロマトグラフ系を見出そうとして, Sephadex LH-20 とアルコールとの組合せ を種々陚みた結果，n-ブタノール（99\%）と平衡化させた場合に最もよい結果が得られることを見出した。 ステロイドは $\mathrm{C}_{19} \mathrm{O}_{2}-17 \mathrm{KS}, \mathrm{C}_{19} \mathrm{O}_{3}-17 \mathrm{KS}$, THE, E, F, THF + allo THF の順に溶出され, 17OHCS 相互 の分離は良好で，コレステロールは $17 \mathrm{KS}$ の前に溶出される. 本法を尿中の $17 \mathrm{KS}$ および 17OHCS の定 量に適用した結果， $\mathrm{C}_{19} \mathrm{O}_{2}-17 \mathrm{KS}$ と $\mathrm{C}_{19} \mathrm{O}_{3}-17 \mathrm{KS}$ の分離は完全であるが，夫々の分画は40〜20\%程度の不 純物を含むとと，Porter-Silber 試薬に反応する不純物は，大部分が THE 上り早く溶出され，THE およ び THF 分画敒含まれる不純物は非常に少いととが罗出された。本法は尿中の $17 \mathrm{KS}$ 值については大略の 值しか与えないが，17OHCS 值は満足すべき値を与えると考觉られる。

質問：升田 亮祐 この方法は全操作を通じ，どの位の時間がかかるか， butanol を使用されるので time-consuming と考えるが，他の column chromatography との比較においてどうか.

応答: 阪大遺伝 関 得一郎 (1)分離に姴する時間は40時間である。ささらに短縮しようと努力中である. (2)以前に報告した Sephadex LH-20 を使用するクロマトグラフ系は 17OHCS のみに対するもので，今日， 尿中の 17KS, 17OHCS の大体の pattern をしらべるために, Sephadex LH-20 と n-butanol よりなる 系を開発した。 (3)n-ブタノールは，その2.5倍容の $60 \%$ エタノールと混合し， water bath 上で加熱すれば 除去できる.

129. 慢性関節リウマチにおける尿中 $17-\mathrm{KS}$ の分画（第 1 報）

九大温研内科 矢野 良一, ○福田 宗矩

慢性関節りウマチ（以下 RA）は男性に比べ女性に圧倒的に多いこいう事実があり，それを究明する目的 の一端として尿中 17-KS の分画を行なつた。対象は当科へ入院した ARA 基準による classical RA，ま たは definite RA のうち過去に全くステロイドを使用していないもの，および離脱後 3 ケ月以上経過した もの51名を選び測定した。一方刘照としては，同じ慢性疾患である肺結核患者のうち，病型に関係なく，手 術を受けていない安静度 3 度の患者40名を用いた。そしておのおのを年令別，性別に分け比較検討した。測 定は Enzyme hydrolysis ¿ Solvolysis の 2 step hydrolysis を応用した神戸川法に準じて行なつた。結 果：(1) 11-deoxy 17-KS は対照群に比べ RA 群の方が男女とも明らかに低下の傾向を示した。(2) DHA は RA 群の方が男女とも明らかに低下の傾向を示し，特に20〜40才において著明であつた。（3）And+ Etio は男女とも明らかに低下し，その傾向は女より男の方が大であつた。（4) And/Etio は男女とも RA 群 の方が低下の傾向を示し，特に男の20４0才において著明であつた。(5) 11-deoxy/11-oxy では男女ともRA 群の方が低下を示し，41〜60才で著明であつた。(6) stage の進行に從い，11-deoxy 17-KS はやや低下の 傾向がみられたが， stage I 亿おろいてすでに7 例中 4 例に低下がみられた。(7)罹患年数の長いものほど，11deoxy 17-KS はやや低下する傾向を示したが，I 年以内でもすでに半数以上に低下がみられた。 (8)過去に 
使用したステロイド量の多いものほど 11-deoxy 17KS は低下の傾向が強く，500錠以上使用した症例は全 例とも低值を示した。(9) ACTH-test と 11-deoxy 17-KS とはかなりの相関関係がみられ，副腎皮質予備 能の低下したものほど，11-deoxy 17-KS も低下を示した，以上より，RA においては，かなり早い時期か ら副腎由来の Androgen の低下が起つているととが認められた。なお性腺由来の Androgen の低下も推 測されるので，今後検討する予定である.

質問：岡大産婦人科 相良 祐輔 私共の経験からは，性腺由来ステロイドの低下を認め，乙れを 17 dehydrogenase の末梢での利用が不十分のためでないかと考えているが，いかがか. [andr.+Etio] の意義 は,いかがなるととかお教え下さい。

応答: 九大温研内科 福田 宗矩 Andr. と Etiocholanolone の和を比較したのは, Testosterone か らの Androstenedion をかいする体内転換より尿中の代謝産物を知るためである.

質 問: 京大中倹 遠藤 治郎 1) RA 䓡患々者の尿中 $17 \mathrm{KS}$ 分画のパターンにみられた特徽は，す なわち 11-deoxy 17KS の減少と, それに比べて 11-oxy 17KS の減少がすくないととは, 17KS 分画の年 令的推移ににていると思われる。䍜患年数に応じてての変化が増強されるてとは年令的推移と区別しうるか. 2) 11-deoxy 17KS と11-oxy 17KS の解離は, ぞのように解釈されるか, 17KS 分画は多くの前㓺物質か ら由来するのでその解秎が却つかしいが，副腎レベルでの生合成の解離が存在しうるのではないか.

応 答: 九大温研内科 福田 宗矩 RA 群も $\mathrm{TB}$ 群も確汃に年令の増加により低下してくる. しかし $\mathrm{RA}$ 群と TB 群を比較すると, RA 群の方が明らかに低下傾向が強く認められる。 TB 群と健常者では 明らかな差はない，それは TB 群は安静度 3 度の比較的軽症例を選んだためと思われる。11-deoxy 17-KS

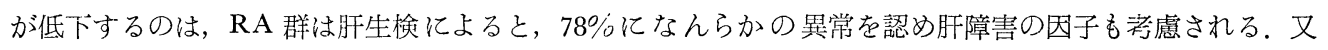
RA 自体の Chronicity 及び RA は女性に多いという事実があり Androgen の分泌低下，あるいは代謝障 害が考えられる。

追 加：岡大產婦人科 鏮田 昌平 我々も数年前に Sysdemic lupus erythematodes の尿中ステロイ ド36分画を測定し，そのステロイドを䣼素を中心に分類し酵素の作用を受けたステロイドはすべて低值を示 すが，てれを全ステロイドで割つた值，即ち䤃素パターンと呼んでいるものは高值を示すという極めて興味 ある成績を得ている，又分画の特異性は，テストステロン，エストラジオールといつた $17-\mathrm{OH} \mathrm{C}_{19}, \mathrm{C}_{18}$ ステロイドが増量していたので追加する。

130. 副腎皮質疾患及び類宦官症における尿中 $\Delta^{5}$-pregnenetriol 及び pregnanetriol につい $\tau$

東大泌尿器科 高安 久雄, 木下 健二, 岩動孝一郎, ○松本 泰

我々は第41回本総会において, ガスクロマト法による正常人尿中 $\Delta^{5}$-pregnenetriol 及び pregnanetriol に関して報告し，それぞれの平均值及び絜準偏差は $\Delta^{5}$-pregnenetriol が $0.15 \pm 0.09 \mathrm{mg} /$ day pregnanetriol が $0.29 \pm 0.17 \mathrm{mg} /$ day であるととを報告した。 今回は副堅皮質疾患 (primary aldosteronism, congenital adrenal hyperplasia, cushing's syndrome) 及び類宦官症に関して検索したので報告する. primary aldosteronism 及び類宦官症では $\Delta^{5}$-pregnenetriol pregnenetriol 共に正常範囲に含まれた. congenital adrenal hyperplasia では $\Delta^{5}$-pregnanetriol, pregnanetriol 共に著しい增加を認め, ての際正常では測定され ない pregnanetriolone 及び pregnenetriol も高値を示した. cushig’s syndrome 亿おいては，その原因が 副腎の過形成及び腺腫の場合には， $\Delta^{5}$-pregnenetriol, pregnanetriol 共に正常範料であつたが，癌腫による 場合では $\Delta^{5}$-pregnenetriol は全例に pregnanetriol は 3 例中 2 例に著しい上昇を認めた。この $\Delta^{5}$-pregnenetriol を測定するととは cushing’s syndrome において，腺腫か，癌かの鑑別の際に有用な一手段となろう。 追 加：岡大産婦人科 鎌田 昌平 我々は Cushing Syndrome の Pregnenolone の尿中排泄物である $\Delta^{5}$-Pregnenediol を测定しているが正常例の 2 倍程度に認めているので追加する.

質問：岡大精神経科 高坂 睦年 沢山の経験の中に Lidopathic hirsutism があつたら, その成績を 御教え下さい. 
質 問：新大第一内科 近藤 隆 Congenital adr. hyperplasia の1例で And. Etio. DHA. を計 測してあつたらお教え願いたい.

応 答 : 東大泌尿器科 松本 泰 (1) data を持つていない. (2) 我々の gas chromatograph 法では almina colum chromatograph で最初の fraction で落してしまうので, 17KGS に関しては特に check し ていない.

131. 各種疾患における尿中分画值について

新潟大中央検查部 小網 悦子, 尾形稔, 石田マス之

各種疾㭧における尿中 $17 \mathrm{KS}$ 分画を GLC で測定した所，次の結果を得た。まず正常人の各分画の平均 值は, 男子, An. $3.21 \mathrm{mg} /$ day, Et. 2.27, DHEA 1.16, 11-OH-An 0.64, 11-OH-Et. 0.15, 11KAn. 0.07, 11 KEt 0.22, 女子, An. 2.26, Et. 2.08, DHEA 0.97, 11-OH-An 0.48, 11-OHEt 0.20, $11 \mathrm{KAn} 0.04$, 11KEt. 0.24 で, Et./An. は, 男子 $0.76 \pm 0.30$ ，女子 $0.92 \pm 0.36$ あ゙つた。単純男性化を示した 21 hydroxylase の 部分的欠損による Adrenogenital Syndrome では, An. Et. 11-OH-An, 11-K-An. の增加, DHEA, 11OH-Et. の低下を示し， 3 例とも未同定のピーク 2 つが存在する. Cushing’s Syndrome および Cushing’s disease では全例で Et./An. が大きく, 副腎ガンでは, DHEA が $39.7 \mathrm{mg} /$ day 亿達していた, adrenal

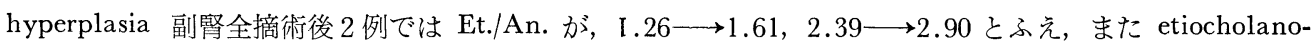
lone 系 $(5 \beta)$ は total $17 \mathrm{KS}$ の76\%，79\%にものぼり，投与した，Hydrocortisone が 17KS では，主と して $5 \beta$ へ代謝されるてとが推測される. Turner’s Syndrome 4 例では, いずれも $17 \mathrm{KS}$ 各分画共低值を 示し, Et./An. は0.55〜0.76でかなり低いとてろに分布した. Hypogonadism では Et./An. が1.00と高い. Hyperthyrodism の 4 例では Et./An. が00.30〜0.39 と著しく低いのに比し，Hypothyrodism では，4.67と 著しく高い.

質 問：京大中検 遠藤 治郎 1）私共が従来カラムクロマトグラフィーで $17 \mathrm{KS}$ 分画をみた経験で Cushing は症候群においては11-deoxy 17KS と11-oxy 17KS の比をみると腺腫と過形成の鑑別にある程 度役立つと思われたが，かかる傾向はみとめられたか。２）AGSにみられたX物質について，21-Hydroxylase 欠損による AGS では, 私共が，カラムクロマトグラフィーでは通常の $17 \mathrm{KS}$ 分画の外に Zimmermann 陽性物質をみとめている. (正常者ではみとめられない) その物質としては D-Homo 型が考光ら れたけれぞもそれ以上の検索はしていない，もしかかる物質が GGで検出しうるとすれば可能性として充 分考光られるのではないか。

応答：新大中検 小網 悦子 Cushing 症候群での 11 oxy 分画のブランクは, 定量しなかつたもの である. 1) 11-oxy/11-deoxy 比について 11-OH etiocholanolone, 11-keto-etiocholanolone については, 私達の経験では etiocholanolone と同じ挙動を示すように思える。また 11-oxy/11-deoxy の比は各疾患に おいて有意の差が認められないようなので，あまり意義がないのではないかと思う。2）オーバースケール について ガスクロ定量の前に Zimmermann 反応で total 17KS を測定しているので, 注入直前の溶媒 の量を加筑してオーバースケールしないようにしている.オーバースケールしそうなものに対しては, 感度 で調節もする。

追 加：阪大病理 松本 圭史 京大内科遠藤先生の発言のでとく, 阪大における吾々の経験でも Cush ing 症候群の腺腫の場合は 11-deoxy-17-KS は全例低下していた。

追 加：新潟大第一内科 近藤 隆 未若物質Xについて, 私達も昇温ガスクロマトグラフィーで 17KS 17OHCS の分画測定を行なつているが，矢張り該部に同定不能と思われるピークを検出している，ガ スクロの Tyne. Column の型が異るので, 同一物質かどうかはにわかには断定できないが, congenital adrenal hyperplasia そついては今後問題ののてる点であると思われる.

質問：网大産婦人科 鎌田 昌平 先生はガスクロチャート上で overscale した経験をわ持ちでしょ うか，乙の様な時どの様にして補正されたか.

132. 肝疾患における下垂体副书系の動態 
新潟大中央検查部

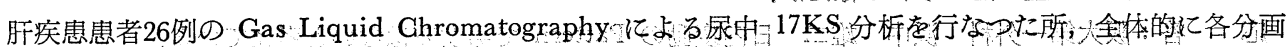

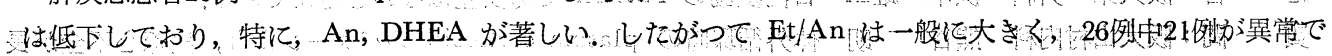

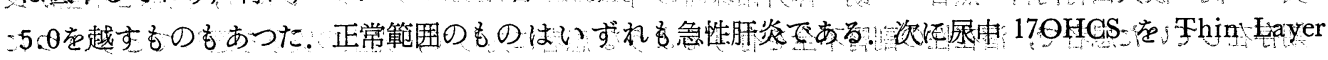

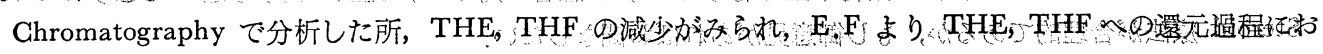

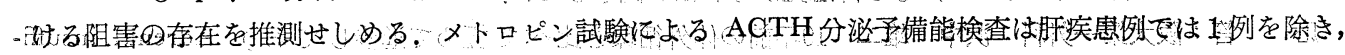

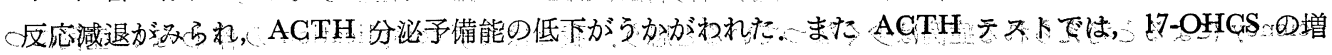
一加为軽度で副婜皮質予借能の诚退を思わしわる成績を得た。

質問：九大温研内科 福田 宗矩 11-deoxy 17-KS 9低下と肝機能検查である膠質系反底々の聞飞相 関が認められたか.

応答: 新潟大中検 小網 悦子 肝機能検查のうち, 急性肝炎については GPT と Et/An の相関図を 書いてみると GPT の高いものは Et/Anも高くなつている. しかし, GPT の低いものでも Et/An の高い ものもあつた. クンケルとの相関については調べていない.

133. 外科手術時における血中 Cortisol, Corticosterone の変動に関する研究

$$
\begin{aligned}
& \text { 阪大第一外科 魚住 徹, 田中 英之, 浜中 雄二 } \\
& \text { 門田 康正, 曲直部寿夫 } \\
& \text { 第二病理 松本 圭史 } \\
& \text { 遗伝 関 得一郎 }
\end{aligned}
$$

挿管麻醉下での胸部外科手術症例15例, 腹部外科手術症例 9 例について, unconjugated cortisol は手術 開始と共に急上昇し術後 $2 \sim 4$ 時間目に術前の 3 倍の peak を示し漸減しながら術後 6 日目になつて日内変 動の pattern に復する. nonprotein-bound cortisol の\%は20\%の peak を示し術後 4 日目から日内変動の pattern を示す. 従つて nonprotein-bound cortisol の浱度にして凡そ30倍にも著增している. unconjugated corticosterone は術後 $2 \sim 4$ 時間目に術前の20倍にも著増している. 体外循環使用による直視下開心 術症例についてみると， unconjugated cortisol は手術開始と共に急上昇するが体外偱環中は低下し，体外 循環終了後再び上昇しその後経日的に濑堿していく. nonprotein-bound cortisol の\%は unconjugated cortisol が低下しているにもかかわらず体外循環中も上昇し続けるという現象が観察された。. unconjugated corticosterone は unconjugated cortisol そほほ parallel に変動する。

質 問 : 弘前大麻醉科 滝口 雅博 質問(1体外偱環時の Heamodilusion による影響はどうか. (2) Hypothermia の影響はどうか。(3)麻酔剂による影響はどうか。【追加】我々もてれまで各種麻酔剤及び手術 侵襲の副婜皮質機能に及ぼす影響を報告して来た。乙れ迄 Ether 及び Penthrone 麻醉下の Hypothermia 中の血中 17-OHCS 濃度の変動を測定したので追加する. Ether 麻醉下では Hypothermia 中でも手術中

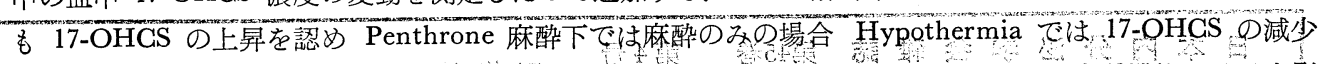

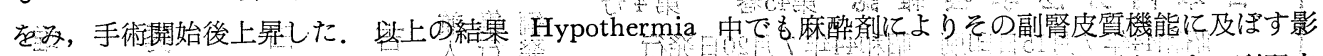
響に差があり，Ether では副緊皮質機能を刺激し，Penthrone では抑制し，手術により禹者ともに副腎皮 質機能は促進されると考光る。

応答: 除大第一外科 浜中 雄二 (1)体外循環申の Haemodilution の点では, 我々の症例では稀釈率

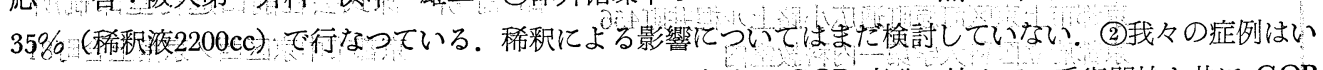

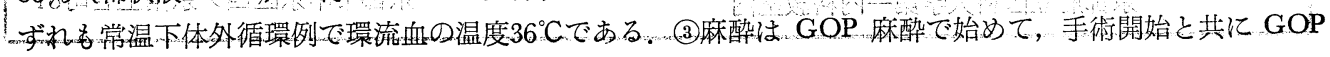
麻醉何換えている. (4)スライドで見せていただいた症例は, plasma 17-OHCS の測定によつているが， 我々の症例は全て Amberlite IRG-50 の Column chromatography で unconjugated cortisol, corticosterone を分画し, Purification して出来るだけ正確に測定している：手術例では種々の薬物投与がなされる ので精製して測定するてとが極めて大切である.

質 問: 名大無菌研 鵜飼 光雄 Plasma cortisol の日内変動に関してそのPattern そ性差があるか. 
ラットでは，その差が梕められる様だが。

応 答: 阪大第一外科 浜中 雄二 日内変動の Pattern で男女差はないと考えている.

質 問：阪大山村内科 熊谷 朗 体外循環時の plasma corticoid のパターンより, 実際心不全が長 期存在していた患者で, 潜在性の副腎不全を有するような患者に対して, 先生の実験を通してぞういつた Steroid 療法が合理的であるか,もし御意見があればお聞きしたい。

応 答: 阪大第一外科 浜中 雄二 10 年前の体外循環と比べて極もて進歩しており. Adrenal insufficiency によると考えられる症例は少くなつていると思う。我々はまず complication の伴わない症例につ いての cortisol の pattern を追求し, 今後は, 種々な complication を伴つた症例 (Adrenal insufficiencyも含めて) についても検討したいと考光ている.

日本内分泌学会雑誌 第 45 巻 第 4 号 昭和44年 7 月 15 日印刷 昭和 44 年 7 月 20 日発行 （毎月 1 回発行） 1 年 金 2000 円

発行所日本内分泌学会 (振替京都12902番) 京都市上京区河原町通広小路上儿梶井町 456 京都府立医科大学第一内科教室内

編集集兼吉田秀雄 印刷人前田政昭

印刷 所 株式会社前田進行堂印刷所 京都市中京区西ノ京南上合町81 